

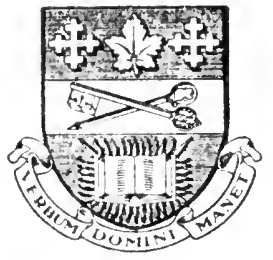

The Leonard Library

\section{Jafprliffe College}

Toronto

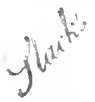

shelf $x$. BV4 30 ens

Register No..1315........

J) wrse $12 \ldots 19 \quad 19$ 


\section{.}


ckiter cturme

tou

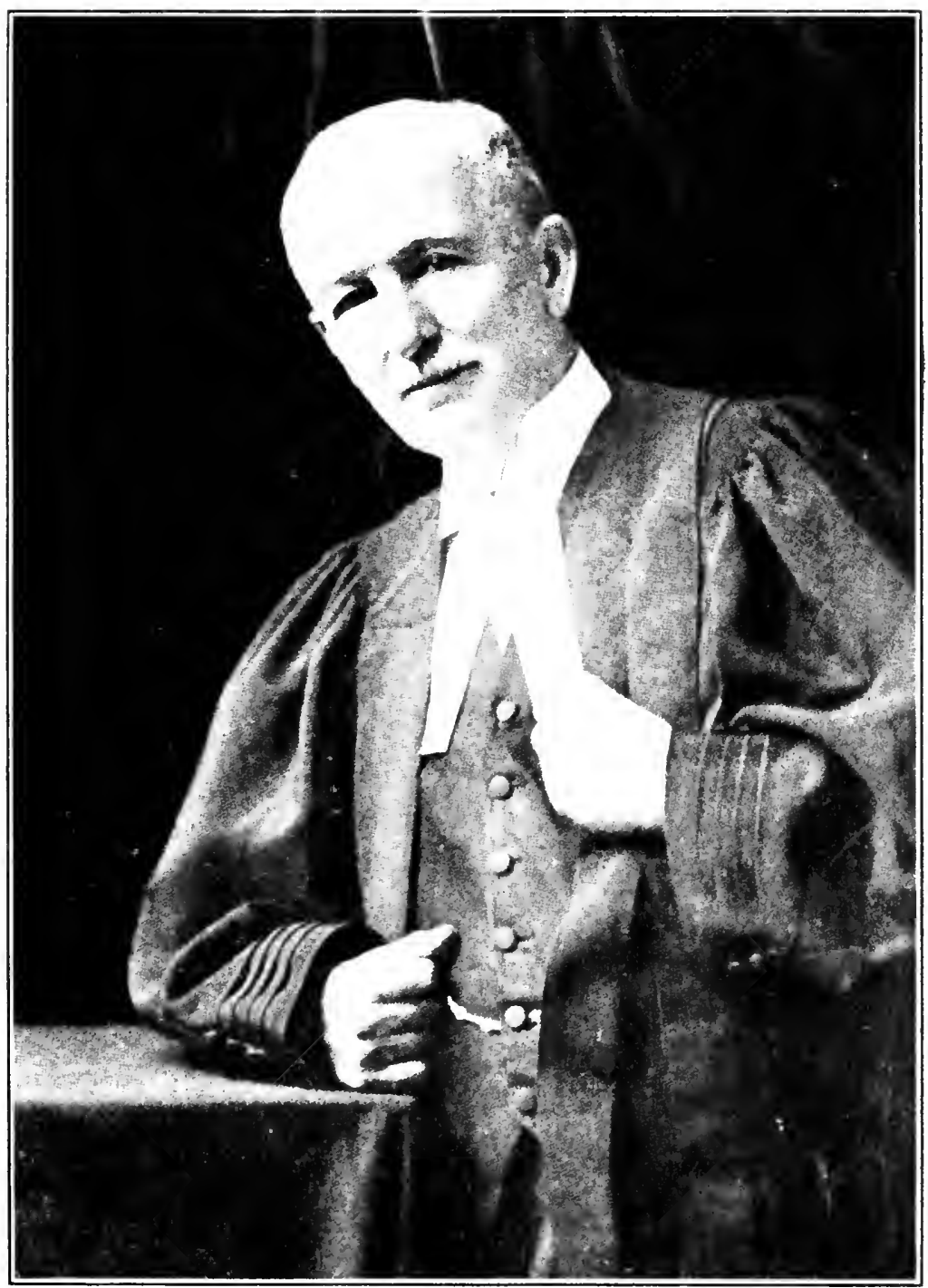





\section{THE MUSIC OF}

\section{THE CHURCH HYMNARY}

$$
\text { AND }
$$

\section{THE PSALTER IN METRE}




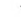




\title{
THE MUSIC OF
}

\section{THE CHURCH HYMNARY AND}

\author{
THE PSALTER IN METRE \\ ITS SOURCES AND COMPOSERS
}

HY

IVILLIAM COWAN AND JAMIES LOVE

\section{HENRY FROWDE}

EDINBURGII, GLASGOW, BELFAST, LONDON ANI NEW YORK 
452061636 


\section{PREFACE}

Tins work has been undertaken with the object of supllying, in a form convenient for reference, information regarling the sources and composers of the music of The Church Hymnary and the companion rolume The Psalter in Metre and Seripture Paraphrases with Tune:.

The book is clivided into tro sections, historical and biographical.

In the former section the aim has been to give under the name of each tune, chant, and siecial setting, the exact title and date of the book or other publication in which it originally appeared. This is followed by such information as has been obtainable in regard to the worls for which the music was composed, the changes which it has undergone, and any other particulars of interest as to its uage and history. In a few cases, in spite of much researeh, it his nut heen found possible to name lefinitely the original source of the musie, and in others further investigation may reveal an earlier source than that now cited; but in each instance every care has been taken to verify the statements made, and it is helieved that these may be taken as at least reliable starting-point; for future research. At the end of this section there is adiled a list, arranged in chronological order, of all the works which have been cited as sources.

In the biographical section will be found notices of all the composers represented in The Chureh IIymnary and The I'salter' in Ietre. These notices are necessarily very brief, and are confined to the main facts of the composers' careers. For fuller information as to their lives and works, reference must be made to the musical and $\underset{v}{\log g r a p h i c a l}$ dictionaries. 
In the musical quotations from the older books the notation has been modernised, and the G clef used uniformly for the melodies.

The information as to tunes of German origin has been to a considerable extent derived from the important work by Dr. Johannes Zahn entitled Die Melodien der deutschen evangelischen Kirchenlieder.

We have to express our thanks to the numerous friends and correspondents who have favoured us with information; and we desire specially to acknowledge our indebtedness for much invaluable help to the late Sir John Stainer; the Rev. Mr. Mearns, Ashby ; Mr. F. G. Edwards, Mr. J. E. Bumpus, Mr. Henry King, and Mr. J. R. Griffiths, London; and Mr. J. O. Anderson, Edinburgh.

WILLIAM COWAN. JAMES LOVE.

Arril 1901. 


\section{PART I}

\section{HISTORICAL NOTICES}

$$
\text { OF THE }
$$

TUNES, CHANTS, AND SPECIAL

$$
\text { SETTINGS }
$$




\section{Hy. = The Church Hymnary. \\ Ps. $=$ The Psalter in Metre.}




\title{
HISTORICAL NOTICES
}

\author{
OF TILE
}

\section{TUNES, CHANTS, AND SPECIAL SETTINGS}

Abba. Hy. 147 .

J. liaribi.

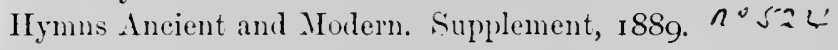
Composed for this hymn.

Abbey. Hy. 235. I's. 27.

The CL. P'salmes of 1)avid, in Prose and Mecter: With their whole manall Tunes, newly enrected and amented. Hereuntu is adled the whole Clunrch Discipline with many gorlly prayers, and an exact kalendar for xxv. yeeres: and also the Sinng of Moses in Meeter, never before this time in print. Edinburgh, l'rinted by Andro Hirt, Anno 1615.

In this edition of the Scottish linok of Common (Mrder or P'alm look, there appear's for the first time a selection of 'Common' tunes, so called to distingnish them from the 'I'roper' tunes which were attached to farticular I'salms. These common tunes are printed in a section by themselves under the heading, "The xii. Common Tunes, to the which all Psalmes of eight syllables in the first line, and sixe in the next may bee sung'; and the tunes themselves are naned as follows: Olde Common Tune, Kinges Tune, Dukes Tune, English Tune, French Tune, London Tune, The Stilt, Dumfermeling Tune, Dundie Tune, Abbay Tune, Glasgow Tune, Martyrs Tune. This is the earliest appearance in print of 
Kings, 1)ukes, French, York (Stilt), Dunfermline, Abbey, Glasgow (not the tune now known under this name), and Martyrs. The other four tunes are found in English Psalters of earlier date. The first appearance of ' $A$ bbey' in an English Psalter is in Ravenseroft's Whole Booke of Psalmes, 162I, where it is classed as a 'Scottish Tune.'

Abends. Hy. 352.

II. S. OAKELEY.

Church Hymnal (authorised by the Irish Episcopal Church), I874.

Composel for this hymn. The harmony was revised for the Church Hymnary by the composer.

Aber. $\mathrm{Hy}$. 64 .

IV. H. Moxk.

Hymns Ancient and Modern. Enlarged edition, I 875 .

Composed for this hymn.

Aberdeen. Ps. 167.

R. BRown-Borthwick.

The Supplemental Hymn and Tune Book, compiled by the Rev. R. Brown[-Borthwick], I 867.

Composed expressly for the first version of Psalm 136.

Aberfeldy. Ps. 225.

The Psalms of Davil, in Prose and Metre: with the whole Forme of Discipline, and Prayers, aceording to the Church of Scotland. Aberdene, Printed by Edward Raban, I633.

This tune and 'Bon Accord' are examples of what are called in the Scottish Reformation Psalter, 'Tunes in Reports,' that is containing passages in which the several parts follow each other in plrases of imitation. The present tune appears for the first time in the above-namerl edition of the Scottish Book of Common Order. It is there placed among the Common Tumes, and is named 'Montrosse Tone.' The tune 'Bon Accord' is also in the volume, but it had already appeared in $\mathbf{I}^{625}$. In both of these tunes the 'Trebble' is marked as the 'Church part' or melody. In the Psalm book printed by Andro Hart's heirs in I635, this tune is set without a name to Psalm 2 I. The name 'Aberfeldy' seems to have been given by II. F. Diblin, who inclurled the tune in his Stantard Psalm Tune Book, I851. There are 
one or two slight differences (principally in the inner parts) between the tune as now given and as printed by Raban and Hart.

Absolutio. Hy. 176.

IV. HITELY.

Privately printed in 886 for the use of the Musical Assuciation of Free Sit. Cieorge's Chureh, Elinhurgh. The Chureh Hymuny is the first hook in which it has been ineluderl.

Composed for this hymm.

Adeste Fideles. $11 y, 30,31$.

In spite of murh direusion and investigntion, the origin of this tme, as well as that of the worls with which it is assinciated, remains rery obseure. It has been frequently stated that the muse was amposed either hy John lieading, who was

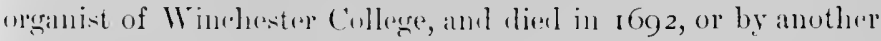
binglish musician of the same name, whe was a pujple of I)r. John libow, and dieel in 1764. This assertion seems to rest solely on the anthority of Vinerent Novello. In a colleretion publisherl hy him in is $8+3$, entitled llome Mnsie, the Congregational and Choristers" P'slum and 11 ymu biook, ete., the music appears arranged as a pasm tume, set to Psiln 106 . It is hearled ' $\mathrm{Air}$ by Rearling, 1680,' and the folluwing note is appented :- 'John Rearling was a pupril of 1)r. libow (the manter of l'ureell), and was lirst employed at Lineohn (athedral. He afterwards becane organist to St. John's, IIackney, and finally of St. Dunstan's-in-the-West, and st. Marr, Woolnoth, Lindon. He published towarls the end of the seventecuth century a collection of anthens of his own composition, and his probluctions ane erenerally esteemed for their tastefully simple melodies and apporptiately matural harmonics. This piece obtained its name of " The I'ortuguese Iymm" from the accidental ciremustance of the Inlir of Lends, who was a director of the Concert of Ancient Music, many years since (ahout the year $17 S_{5}$ ) having hearl the hymn hirst performen at the Portuguese Chapel, and who, supposing it to be peculiar to the service in Portugal, loe introduced the melorly at the Ancient Concerts, giving it the title of "The Portugutese Hymu," by 
which appellation this very favourite and popular tune has ever since been distinguished; but it is by no means confined to the choir of the Portuguese Chapel, being the regular Christmas hymn, "Adeste Fideles," that is sung in every Catholic chapel throughout England.' As Novello was for many years organist of the Portuguese Cliapel, the latter part of the above note may be taken as giving a correet aceount of how the hymn became known beyond the Roman Catholic churches, and reeeived the name of 'The Portuguese IIymn.' Novello's statement as to the eomposer of the music is, however, a different matter. In the first place, the date 1680 in the heading is certainly inconsistent with the note, for the John Reading whose career is described in the latter was not born till $\mathbf{1} 677$. Further, nothing in the least resembling the nusic of 'Adeste Fideles' has been found either in any of the seeond John Reading's published works, or in two manuseript rolumes in his antograph now in the possession of Dr. W. H. Crmmings. As to the elaim of the older John Reading, the organist of Winchester, no evilence whatever has been produced in its favour; and in the absence of such, the mere name and date given by Novello in 1843 seem hardly worth consicleration.

So far as has yet been aseertained, the earliest book in which the unsic appears in print is a small volume entitled ' An Essay on the Church Plain Chant. London : Printed and published by J. P. Coghlan, in Duke Street, Grosvenor Square. Mocclxxxu.' The book is in three parts, and the 'Adeste Fideles,' with its music, is in the second of these, which is headed 'Part Second, containing several Anthems, Litanies, Proses, and Hymns, as they are sung in the Publie Chapels at London.' No composers' names are given in the rolume, except in the case of two settings of the 'Tantum ergo,' which are saisl to be 'by Mr. Paxton.' In his 'Allvertisement' to the publie, Coghlan, the publisher, says, 'It is neeessary to observe that the Third Part, or Supplement to this work, was not eompiled by the Gentleman who dil the other 'Two Parts.' It seems highly probable that the 'Gentleman' so referred to was Samuel Webbe, senior, for nearly all of the pieces in the seeond part of the volume (including the 'Adeste Fideles' and the tune now known as 
'Melcombe') appear again in W'bbe's Collection of Motetts or Antiphons, 1792, and several of them have his name appender to them there as composer.

Although the lisay on the Chureh Plain Chant is at present the earlient book known to contain the 'Adeste Fileles,' it is found in manuseripts of older clate. The earliest of these yet discovered is a volune preserver at Stonyhurst College, Laneashire. It is the work of John Francis Wate, a priest who seems to have employed himself in writing out music for Roman Catholie fannilies and institutions. The rolume is entitled 'Ciutus I)iversi fro Dominicis et Festis per' annum. (iloria P'atri. I'ost Introitum. Kyrie. Gloria in excelsis. Creslo. Sauctus and Aguus Dei. Cum IIymnis et Antiphonis al Elevationem and lienelistionem. Eit ex pripendiis sonent preconia. Nieolans King, lijus Cantus. Joamnes Francisens Wade, Seriptor. Anno Donini, noccli.' The 'Aleste Fideles' in four stanzas, with the musie repeaterl to each, is the second last piece in the volume, and is healded 'In Nativitate Domini II Yrmn11.:'

The words of the hymn have nut been found in any mannseript or bouk of earlier date than that just deseribed. They appear in an edition, published in 1760 , of The livening Office of the Church. The hymn is there intrornced thus: "From the Nativity of our Lord to the Purification, exelusive; whilst the Benedietion is giving, is sung Aleste Fileles, ete.' In previous editions of this hook, pullisherl in 1710,1725 , and $17+8$, the lymm does not appear. The full text reems to consint of eiglit stanzas, of which the first, thiml, fifth, aml sixth, with, more rarely, the fourth, are thise generally in use in France; while the first, seconl, seventh, and cighth represent the English use. It is the latter cento which is found in the Stonylurst ILs., in all the books now referred to, and generally in all knglish collections, whether in the original Latin or in trinslations.

The conclusion seems to the that the hymn and tume eame into use together, in the services of the Roman Catholic Chmreh, during the first part of the eighteenth century; that they were in eirculation in manuscript for some time before they appeared 
in print, but that nothing definite ean as yet be stated as to the author of either words or music.

Adoration. Hy. 92.

G. J. Elvey.

The New Mitre-Hymnal adapted to the Services of the Chureh of England, with accompanying Tunes, I 875 .

Composed for the hymn 'Hark the sound of holy voices.' Original name, 'Urbs cœlestis.'

Adrian. Hy. 488.

R. P. Stewart.

The Church of England Hymnal, i 895.

Composed for the hymn 'All the way my Saviour leads me.'

Adsis Jesu. Hy. 374.

IV. H. Monk.

The date of composition is uncertain. The MS. of the tune was given by Mrs. Monk, after the composer's death, to Dr. A. H. Mann, the musienl editor of the Chureh of England Hymnal, and it was included in that book, published in 1895 , set to the hymn 'In the hush of even.' The tune is there called 'Departed.'

Agapé. Hy. 418.

J. B. Calkin.

The Hymnary, 1872.

Composed for the hymn 'Jesu, most loving God.'

In the (Irish) Church Hymmal, 1874 , it is named as above, and set to the present hymn.

Agnes. $\mathrm{Hy} .181$.

E. Bunnet'1.

The Hymnal Companion to the Book of Common Prayer. Second edition, i 877 .

Composed for the hymn 'Jesu, from Thy throne on high.'

Agnus Dei. Hy. 171.

J. Barnby.

Original Tunes to Popular Hymns, for use in Chureh and Home, eomposed by Joseph Barnby, I869.

Composed in 1866 for the use of the church of St. Andrew's, Well Street, to the hymn 'Sweet is Thy mercy, Lord.'

Aldersgate. Hy. 143.

G. P. Merrick.

The London Tune Book, a Companion to all Hymnals now in use, [1877]. Edited by Edwin Moss.

The tume is not referred to any particular hymn. 
Alexandria. P's. 148.

II. J. GalithetT.

The Hallelujah, edited by the Rer. J. J. Waite ant II. J. Gauntlett, $1851-56$.

Alford. Hy. 341 .

J. 13. WYKES.

Hymns. Ancient and Modern. Enlarged eelition, 1875 .

Composerl for this hymm.

In a letter to Mrs. lykes on the oceasion of the compuser's death, Sir Henry liaker says, "We are going to sing only lis tunes to every liymm all next sunday, and the "Dies Irae "after Evensong-for him; followed hy "Ten thousand times ten thousantl.",

All for Jesus. Hy. 218.

J. STAINER.

The Crucifixion: A lleditation on the Sacred Passion of the Inwly Rerleemer. The Inusic by J. Staner, is87.

The work contains several hymins 'to he sung by the enngregation.' The present tune is that set to the hymn 'All for Jesus-all fur Jesun, This our song shall ever be.'

All this night. IIy. 5.31.

1. S. Sulditax.

Christmas Carols New and (olid, edited by the Rev. II. IR. limanley and sir Joln stainer. Secoml series, is 8 o.

Compereerl for this hymm.

Allhallows. IIy. 69.

1. H. Brow:

The Bristol Tume liook, 1863 .

The composer stites that the tune may have been printerl previous th this date in a chureh perioslieal.

In the liristul 'Tune liook it is set to the hymm 'Beyourl, beyond that bomulless se'a.'
Almsgiving. $\quad \mathrm{Iy}, 423$.
J. 1. 1) ҮKEs.

The Holy Year, by Charles Wordworth, I).I), with alpwe. priate Tunes, wlited hy. W. Monk, I 865 .

Composed for this hymm.

Incluted in the Aprendix to Iymms Ancient and Motern, I 868.

Alstone. IIy. 5i

C. E. Wildivg.

Hymms Aneient and Modern. Appendix, s 868.

Composed for this liymu. 
Amor Dei. Hy. 210.

Oeffentliche Kirehen-Gesänge, von D. Martin Luther und andern geistreichen Mïnnern zusammen getragen. . . . Bremen, 1707.

In this work the melody stands thus-

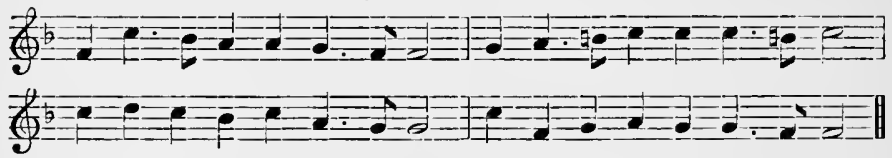

and is set to the hymn 'Hör' liebe Seel, dir ruft der Herr.' The present arrangement was made by Sir Joln Stainer for The Church Hymnary.

Angel Voices. Hy. 396.

E. G. Monk.

Composed for this hymn. Both hymn and tune were written at the request of the Rev. W. K. Macrorie, afterwards Bishop of Maritzburg, for the opening of an organ at Wingate Church, Lancashire, in February 1861. The Rev. Francis Pott, author of the hymn, states that the tune was repeatedly printed in Choral Festival books and similar publications. It appears in The Congregational Church Hymnal, 1887, and in the Supplement to Hymns Ancient and Modern, i 889, but may have been inclucled in collections of an earlier date.

Angels' Song. $\mathrm{H}_{\mathrm{y}} .376 . \mathrm{Ms}, 1,2$.

O. Gibbons.

The Hymmes and Songs of the Church, by George Wither, 1623 .

This work contains a number of tunes in two parts, treble and bass, by Orlando Gibbons, the jresent being set to the song begimning 'Thus angels sung, and thus sing we.' The meloty stands as follow's:-

(2)

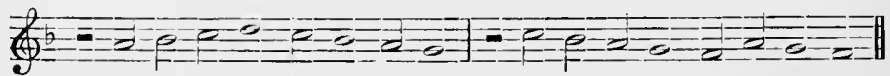

It is also set to another song in six-line form by the adlition of two lines as follows:-

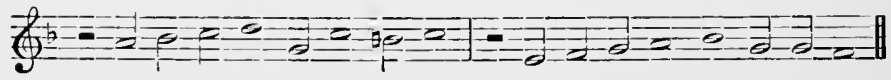


The triple time form of the tune seems to have been introrluced early in the eighteenth century, and is the form usually foumd in both English and Soottish collections down to a comparatively reeent ilate. An abrilged version in common metre aml rommon time, unler the name 'Trestminstre', alpeared in Playfort's l'salms, $167 \mathrm{I}$, and in several uther collections of hater date.

\section{Angels' Story. 11y. 545.}

A. II, Maxs.

The Methodist Sunday School Tune Book, I 88I.

Composed for this hymm.

Angelus. $11 \% 111$.

R. Jarkisos.

Sierenl Leaflets for Chureh and ITome. Hymm Tunes composed by Robert Jallism, [cirea 1885$]$ ].

Composed for the hymm "When the day of toil is done.'

Angelus. $11 \mathrm{y} .353$.

(i. JOSELH.

Ieilige reelenlust, orker Geistlirhe Hirton-Liecler . . . von

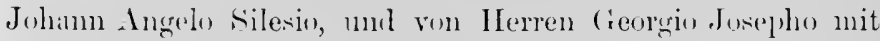

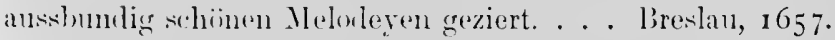

Though this volume has alwalys been riterl as the sompe of the presint tune, the first line and half of the secoml are the only jarts of it which are really to be fomel there. The entire tune has not boen discovered in any arlier publication than the following :-Cantica spiritualia, orler Auswahl ter seliinsten gristlichen Lierler iilterer Zeit, ete., vol. ii., Munich, 1847. In this it alpuras in its present form, set to the hymm

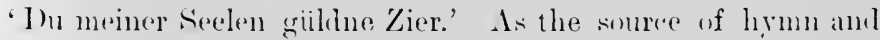
tume, the erlitor of Cantiea Spiritualia names the 1657 bonk, of which the title is criven alover, and also Iram's beho Hymnolia Coelestis, I675. The melonly of the hymn 'Dn meiner Seelen, etre,'in buth of these burk is exactly the same, and is as follows:-

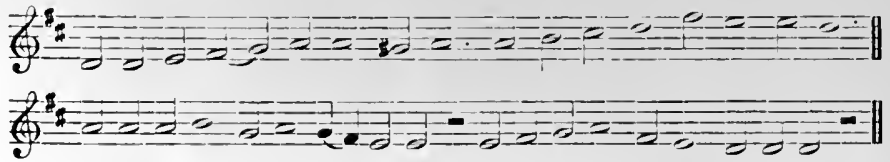

Dr. Wr. Baiunker is of opinion that this, the original melorly, was arbitrarily altered by the editor of Cantica Spiritualia. 
It was evidently from this work, and not from the original, that the tune was taken when it was set to the present hymn in the Appendix to Hymms Ancient and MLodern, I868.

Antioch. Hy. 458 .

C. Steggall.

The Song of Praise; or Psalm and Hymn Tunes, collected and arranged by Vietoria Evans-Freke, i 876.

Composed for the hymu 'By Christ redeemed, in Christ restored.'

Argyle. Hy. 96.

E. H. Turpix.

Hymn Tunes, edited by E. H. Turpin, 1872.

No words are attached to the tunes in this eollection.

Armageddon. Hy. 269.

Alapted by J. Goss.

The Church Psalter and IIymn Book, by the Rev. IT. Mereer. Appendix, I872.

Set to the hymn 'Onward, Christian Soldiers.' The tune seems to be an adaptation from the following melorly, which appears in Part III. of Layriz's Kern des deutsehen Kirehengesangs, r 853 , set to the hymn 'Wemn ich Ihn nur habe,' and ascribed to Luise Reichurdt.
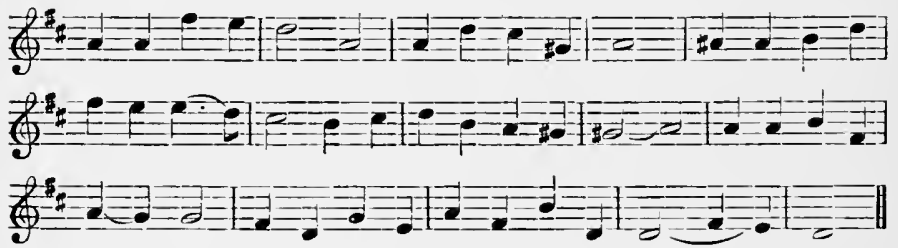

Arms of Jesus. Hy. 593.

IT. II. DonNe.

Songs of Devotion for Christian Associations, s87o, edited by W. H. Doane.

Composed for this hymu.

Arnold. I's. 28.

S. Arnoli.

The Psalms of David for the use of Parish Churches. The Music selecterl, arlapterl, and composed hy Dr. Arnoll . . assistel by J. WT. Calleott, 1791 .

The tume is taken from the setting of Psalm is by I)r. Aruold. 
Arnsberg. Hy. 128.

J. NeAxder.

Joachimi Neandri Glaub- und Liebes-iibung: Auffgenuntert dureh Finfiltige Bundes-Lieder und Danck-Psalmen. . . . Bremen, I68o.

$A$ collertion of fifty-six hymns by Neander, the most of them being provided with tunes. This melody appears as follows :-

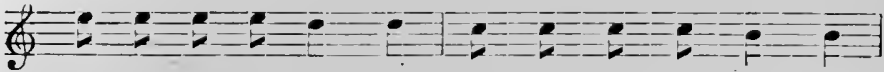

$\Rightarrow \Longrightarrow \Rightarrow=0=0$

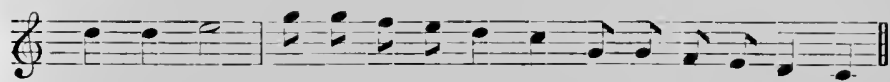

It is set to the hynn ' Wunderbarer Kïnig, Herrscher von uns allen', and is believed on good grounds to be emposed by Neamler.

Arnstadt. $\mathrm{Hy}_{\mathrm{y}} \mathbf{2 9 6 .}$

A. JRESE.

Geistrejehes Gesang-buch. . . Darmstadt, r 698.

The melorly appears as umler, set to the hymm by Drese, 'Seelenbriutigam, Jesil Gottes Lamm -

$\frac{7 b^{2}-0}{0}=-10=0$

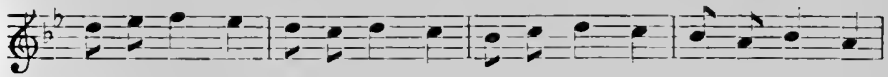

$70^{2}=0$

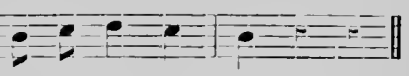

In Freylinghausen's (iesanghuch, z zo4, it appears as follows:-

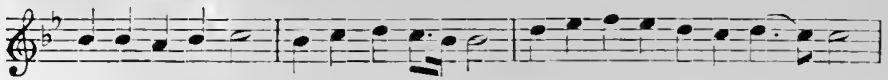

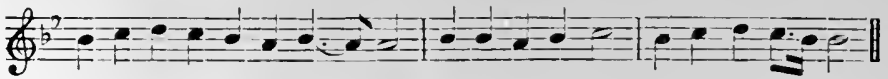

In Reimam's Collection, 1747 , the two first notes of line 2 are

The tune has appeared in English books in various forms 
as regarls both meloly and rhythm; the present arrangement was made by Sir John Stainer for The Chureh Hymnary.

Arran. Ps. 168.

S. S. WesLeY.

A Selection of Psalms and Hymns arranged for the Public Services of the Church of England, edited by the Rev. C. Kemble and S. S. Wesley, I864.

Set to the hymm 'Thy way, not mine, O Lorl.'

Arundel. Hy. 553 .

J. I3. 1)YkEs.

The Congregational Hymn and Tune Book, erlited by the Rev. R. R. Chope, i862.

Composed for the hymn 'Lord, have mercy and remove us.'

Ashgrove. Hy. 286.

H. Sirart.

The Presbyterian Hymnal, i8 77 .

Composed for the hymn 'I eannot, no I will not let Thee go.'

Aspiration. Hy. 560.

A. L. Peace.

The Seottish Hymnal, I885.

Composed for this hymn.

Aspurg. Ps. 29.

J. G. Frech.

Vierstimmige Gesänge der evangelischen Kirche. Stuttgart, 1825 .

Set to the liymm 'Singt unserm Herrn ein dankroll Lied.'

Assisi. Hy. 63.

F. II. Champneys.

Hymns Ancient and Molern. Enlarged edition, 1875.

Composed for this hymn.

Augustine. Hy. 313.

The music from which it is believed this tune is lerived is that which is fouml in eonnection with the Hymn or Sequence, sail to be by Peter Abelarl, beginning 'Mittet ad Yirginem,' sung on the festival of the Annuneiation. A German version of this hymn appeared in the Gesangbuch edited by Michael Weisse, in 1531 . The German hymn begins ' $A$ ls der gitige 
Gott, vollenden wollt sein Wurt.' From this the hymn and tune passed into various German collections, and in IBach's Vierstimmige Choralgesinge, I 769 , it is fomml in the following form :-
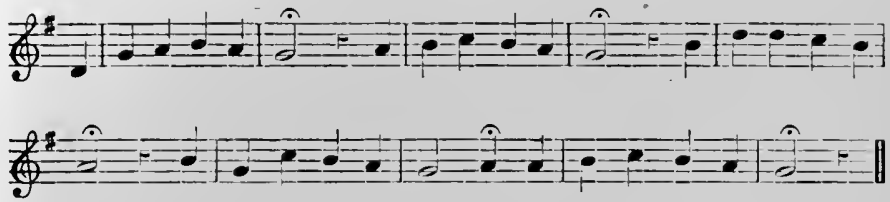

Aurelia. IIy. 454.

S. S. MESLEY.

A Selection of Psalms and Hymns arranged for the P'ublic Services of the Church of England, edited by the Rev. Charles Kemble and S. S. Wesley, i 864.

Composed for the hymm 'Jerusalem the goliten.'

It is set probably for the first time to 'The Chureh's one fommlation,' in the Appendix to Iymus Ancient and Modern, I868, and is now universally associated with that hymn.

Austrian Hymn. Ily. 461.

J. ILAYUX.

Composed for the national hymm by Hauschla, 'Gott erhalte Franz den Kaicer, and first performed on the Emperor's birthday, r 2 th February i 797 . The romponer afterwards used the melody as the subject of one of the movenents of his String Quartet, $\mathrm{N}), 77$.

Baden. IIy. $2>0$.

Auserlesenes Weimmarishes Gesanglumb. . . Weimmar, $168 \mathrm{I}$.

The molody as under is set to the hymm by S. Roligatst, 'Was Gott thut, diss ist wohl gethan,' of which the present is a translation.

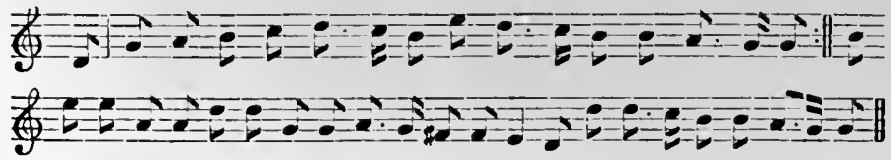

Wetzel, the German hymmologist, states that Roligast wrote the hymm in 1675 for his sick friend Severus Gastorius, Cantor 
at Jena, and that the latter, on his recovery, composed for it the above melody. Winterfeld is of opinion that this tune was composed by Johann Pachalbel of Nürnberg, but Zahn states that there is little foundation for this, and agrees with Wetzel in attributing the melody to Gastorius.

\section{Ballerma. Ps. 30.}

A Selection of Original Sacred Music. . . . Intended to form the Sixth Vol. of Steven's Selection of Sacred MIusic, ellited by John Turnbull. Glasgow, 1833 .

The tune is there attributerl to R. Simpson, but it seems to be an adaptation from a melody published by F. H. Barthélémon, set to the words of a poem entitled 'Belerma and Durandarte,' which appeared in The Monk, by M. G. Lewis.

Bangor. Ps. 31.

A Compleat Melody: or, The Harmony of Zion. . . . By William Tans'ur. (Preface dated Sept. 29, I 734.)

Set to Psaln I 2, and headed 'Bangor Tune. Composed in Three Parts. IV. T.' It is doubtful whether the tune is an original eomposition by Tans'ur, or was merely harmonised by him. In some books the tune has appeared in the Dorian mode, with no flat in the signature; in the original, however, it is in $\mathrm{D}$ minor, as at present.

Barnet. Hy. 125.

A. Cotruan.

Ten Original Tunes . . by Arthur Cottman, [1874].

Composed for the hymn 'Oft in danger, oft in woe.'

In the above publication the tunes have no names; but the tune was ineluterl, with its present name, in The Bristol Tune Book, Second series, 1876 .

Barton. Hy. 98.

E. H. Thorne.

The Church of England Hymnal, i 895 .

The tune was not written for this work, and the composer believes that it was published many years previously. $\mathrm{He}$ is unable, however, to give more definite information, and the endeavour to traee its first appearance has been unsuecessful.

Battishill. Hy. 566.

J. BattisimLl.

Twelve Hymns; the Words by the Rev. Charles Wesley, 
M.A., late stulent at Christ Church, Oxford ; set to music by Jonathan Battishill, $[\mathbf{1} ; 65]$.

The present tune is a much altered and abridged version of the original, which is set to the hymn 'Jesus, Lorrl, we look to Thee,' as follows :-

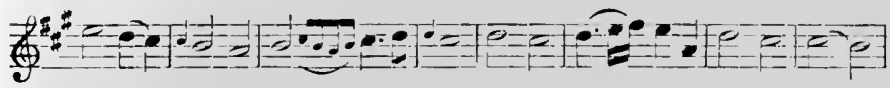

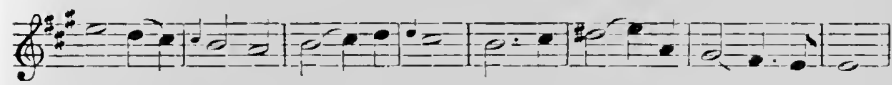

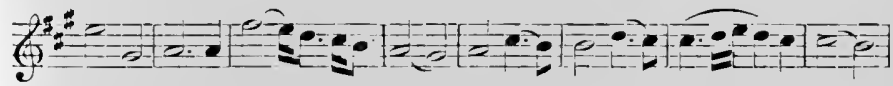

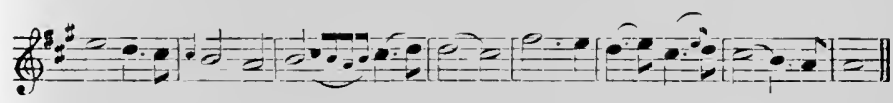

\section{Bavaria. Ps. 3.}

Geistreiches Gesangbuch . . Darmstalt, I 698.

Set to the hymn 'Preis, Lob, Ehr, Ruhm,' as follows:-

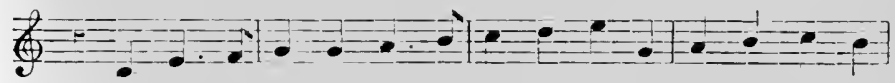

t)

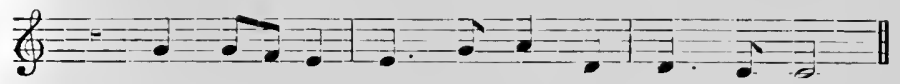

Beati Mortui. IIy. 318.

J. Stainer.

The Crucitixion : A Meditation on the Sacred Passion of the Inoly Redeemer. The M[usic by J. Stainer, $188_{7}$.

The work contains several hymns 'to he sung by the congregation.' The present tune is that set to the hymn 'IIoly Jesus, by Thy Passion.'

Beatitudo. IIy. 328.

J. В. 1)YKES.

Iymns Aneient and Morleru. Enlarged edition, 1875 .

Composed for the hymn 'IIow bright these glorious spirits shine.' 
Beautiful River. Hy. Appx. 14.

R. Lowry.

Happy Voices, 1865 .

Composed for the hymm 'Shall we gather at the river,' of which the composer is also the author.

Bedford. Ps. 32, 33 .

W. WIIEALL.

It is not possible to assign an cxact date for the first appearance of this tune, the oldest books containing it being unfortunately undated. Probably the earliest of these is 'The Divine Musick Scholars Guide, $w^{\text {th }}$ the Famous Mr. Tho. Ravenscroft's Psalm Tunes in four parts. Correeted and newly Revir'd. To which is added a choice Collection of new Psalm Tunes, Hymns, and Anthems . . . Collected and Printed by Francis Timbrell.'

The tume is printed twice in this volume, first to Psalm 27 and second to Psalm 84. The latter' is headed 'Bedford tume. By Wm. Wheal.'

It is in three parts, Cantus, Medius, and Bassus, the melody being as follows :-

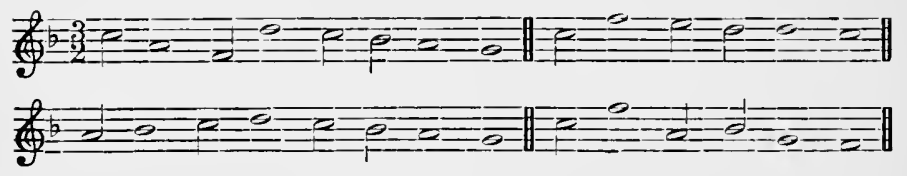

As set to Psalm 27, it is headed 'Bedford Tune,' without name of composer. The melody is the same as above, except in line 3 , which reads thus-

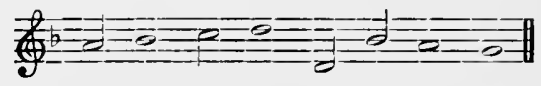

The British Museum Catalogue gives ' I7 5 ?' as the date of Timbrell's book. This is probably too early, but a copy in the possession of Sir John Stainer contains the inscription 'Thomas Bradford ejus liber, i723.'

In 'A Choice Collection of Psalm Tunes, Hymns, and Anthems. . . Colleeted and Printed by Michael Broom, Singing Master, Isleworth, Middlesex,' the tune appears again set to Psalm 84 . It is headed 'Bedford Tune, by WT. Wale, organist of Iiedford, B. of M.,' and the melody is the same as in the setting to 
I'salm 27 in Timbrell's book, the thind line having at I where the usial form has a C. liroom's book is also undated, but a colpy in the lining lilurary, Glasgow, has the antograple of a former owner and the clate 173I. In Matthew Wilkins's lowk of Palmoly, alko molated, but probably iscued about iz3o, the tume is set to I'silm $S_{4}$, the melorly leeing the same as in the setting to that joalm in Timbrell. Mr. Marergal states in his. ()h Church l'salmoly that he had fomm the tme in The I'salm-iugers Magazine, 1729 . This has not been verified, as the bow eamot now be elicoverel, but the tune is contained in 'The Ilarmonions Companion : or', the l'sahn-Ninger's Jagazine. . . . Collected by 1). Smitl, and Corrected ly Mlr. I'. l'rellues, r732.' Here the tune is set to I'silm 1 49, and the syneopated aceents which oenur in erery line in the books alreaty referred

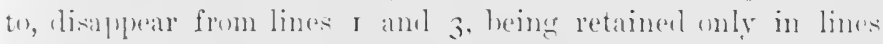

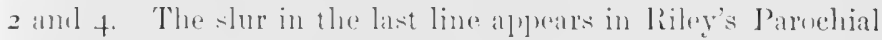

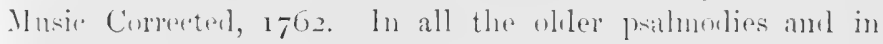
most molern lonks the tume is in triple time. l'robably its

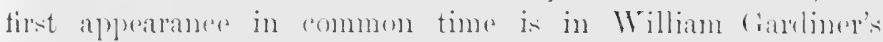
Sacred Melulies, 1812 . Here it is set to the hymm "Onr (ion, onr help in acese past,' the melonly being as follows:-

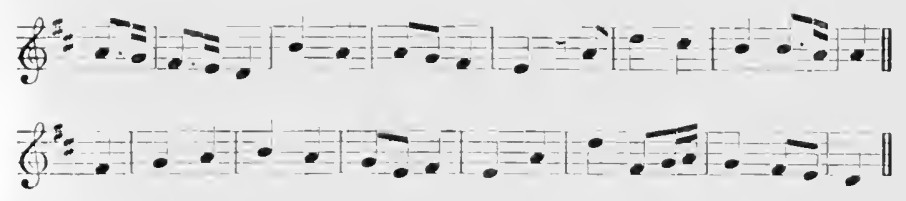

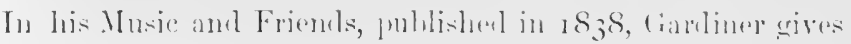
information as to the somrees of some of his caremen Melonlies, and says regarding the above:- "This fine whl tme was written

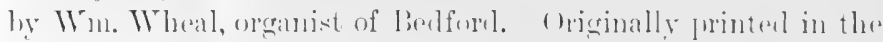
key of linal in triple time, I have chanesel the key to l) and witten it in eommon time, a measure that is more stately and

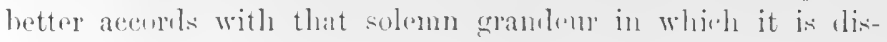
posel to more.'

It is somewhat enious that a tume hearing vory elose resemblance to 'lieulfurel' appeared in a German Roman C'atholic Cresanghueh, printel at Inulerstalt in 1724 . The melouly is 
set to a German translation of Xavier's hymn ' $O$ Deus ego amo Te,' and is as follows :-

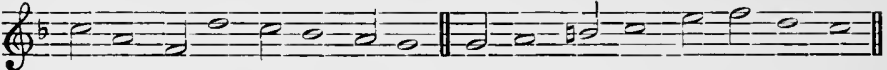

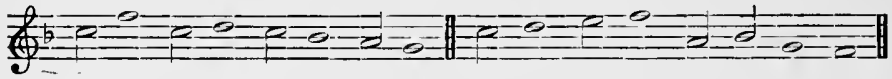

Beechwood. Hy. 526.

J. Вооті.

The Congregational Sunday School Hymnal, i 89ı.

Composed for this hymn.

Belgrave. Ps. 34.

W. Horsley.

National Psalmody . . A Collection of Tunes . . The Music harmonised, arranged, and adapted by B. Jacob [I8I7].

The present tune is marked in the Index as a new composition. It is set to Psalm I6, ver. 5, 'My lot is fallen in that blest land.'

Belmont. Hy. 583. Ps. 35.

This tune has been ascribed to Samuel Webbe, to his son Samuel Webbe, jun., and also to Mozart; but there are no sufficient grounds for assigning its composition to any of these. It appears to be an adaptation from a melody in William Gardiner's 'Sacred Melodies . . . adapted to the best English Poets, vol. i., I8I2.' This consists of eight lines, and is set to Dr. Watts's hymm 'Come hither, all ye weary souls.' The first half of the melody is as follows:-
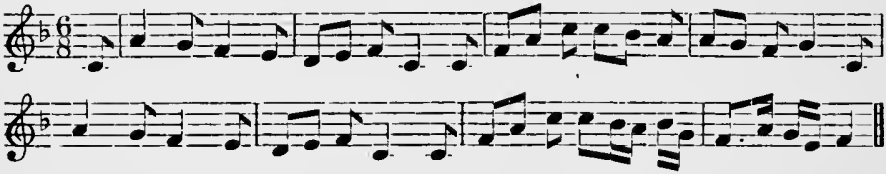

To name of composer is attached, but in a catalogue appended to his Music and Friends, 1838 , Gardiner cites it as his own composition. The tune appears, practically in its present form, in A Chureh IIymn and Tume Book, 1859 , where it is said to be harmonised by J. Bentley; in Rontledge's Church and Home Metrical Psalter and Iymnal, ז860; and in other books of about the same clate. 
Ben Rhydding. Hy. 266.

A. R. Reinagle.

The Supplemental Hymn and Tume Hook, compiled by the Rev. R. Brown[-liorthwiek], I867.

Set to the hymm ' Not all the blond of beasts.'

Bentley. IIy. 220.

J. Hillait.

Psalms and IIymns for l)ivine Worship, r 867.

Composed for this hymm.

Bergholt. Hy. 600 .

1. H. linows.

The Methodist findily sichool Tume Book, r 88r.

Composed for the hymm 'The morning bright, with rosy light.'

Berno. Hy. 366.

1. H. Mars.

The Chureh of Englind Hymmal, 1895 .

Composed for this hymm in $S_{74}$, but I)r. Mann does not think it was ever jublished, till its appeamnce in the above book, of which he wis musicil enlitor.

Bethany. IIy 71 .

E. Beximetr.

Twenty-four original tmes set to favourite hymns, by Elward Bunnett, is8o.

Composed for the hymu 'Sun of my soul.'

Bethany (Crucifer). Ily. 81, 246, 476.

II. SuART.

P'silms and Iymus for I)ivine Worship, 1867.

Composed for the hymm 'Jesus, I my ross have taken' (No. $24^{6}$ ). The original name of the tume is 'Bethany' but the name 'Crurifer' has heen given to it in several enllections, on aceont of its connection with the above hymm.

Bethesda. Hy. 622.

II. S.MAKT:

The Presbyterim Hymull, 1877.

Composed for this hymn.

Bethlehem. Hy. 28. Mexuenssom. Arr. hy II. H. Cummas. Festgesang for Male Chorus and Orchestra, r 840.

Composed for and first performed at the festival heh at Leipzig in June a fo to celehrate the invention of printing. The tune is arlapted from the chorus No. 2 of thit work. When 1)r. W. H. Cummings was organist at Waltham Abbey 
it struck him that this chorus would be a suitable setting for the hymn 'Hark, the herald angels sing.' He copied out the parts, and had the tune sung by the ehoir at W'altham Abbey. Finding that it was received with favour, he published the adaptation in 1856 , and it soon found its way into many hymm books, the first of these being the Rev. R. R. Chope's Congregational Hymm and Tune Book, 1857 , where the tune is called 'St. Vincent.' When included in Hymus Ancient and Modern in $\mathbf{r} 86 \mathrm{r}$ an unwarrantable alteration was made at the end of the twelfth bar, two slurred minims $B$ and $A$ being substituted for the single semibreve $A$ of the original. In The Church Hymnary the original note has been restored, and also the dotted notes of the original at the beginning of lines $5,6,7$, and 9 .

It is somewhat curious that some years previous to the publication of Dr. Cummings's adaptation, Mendelssohn in writing to his English publishers on the subject of an English translation of the Festgesang, said: 'I must repeat the wish I already expressed in my letter to Mr. Bartholomew. I think there ought to be other words to No. 2. If the right ones are hit at I am sure that pieee will be liked very much by the singers and the hearers, but it will never do to sacred words. There must be a national and merry subject found out, something to which the soldier-like and buxom motion of the piece has some relation, and the words must express something gay and popular as the music tries to do it.'

Bethlehem-Ephratah. Hy. 33.

J. BaRNBY.

The Home and School Hymual, r892.

Composed for this hymn.

Better World. Hy. 591.

Adapted by II. P. MAIN.

Richard Weaver's Tune-Book, [1862].

Set to this inymn.

The present arrangement of the tune appeared in Bright Jewels, edited by R. Lowry and others, 1869.

Bevan. Ps. 172.

J. Goss.

Choral Harmony : $\Lambda$ collection of tunes in short score, for 
four voices, a companion to Metrical Versions of Psalms and Hymns, by the Rev. Peter Maurice, 1854.

This tune is headed 'Written for the work, 1853 .'

Beverley. $\mathrm{Hy} .113$. II. H. MoNk.

Hymus Ancient and Modern. Enlarger edition, I875.

Composed for this hymm.

Bishopthorpe. P's. 36 .

J. Clark.

The Psilms of David for the use of Parish Churches. The Music Selected, Arlapted, and Composed by Elwarl Miller, Mus. Hoc., I 790.

The tme has not been traced to any arlier book than the above, where it is named as at present, and assigned to Jeremiah Clark. It may be an adaptation by I)r. Miller.

Bloxham. Ps. 37 .

Williams's New Lniveral P'salmodist, 1770.

Set to Dr. Wattris version of P'salm 34 .

The meloly is as follows:-

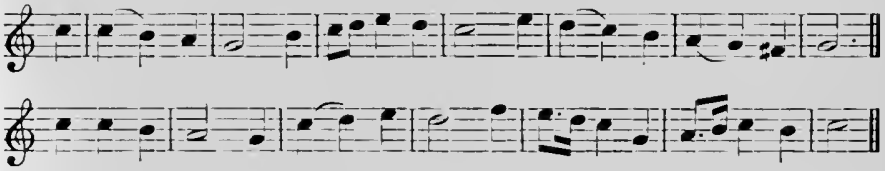

Bohemia. IIy. 611 .

The Church P'salter and Ilymu look, editerl by the Rev. Wm. Mercer, I 85 t.

Set to the hymn 'In the hour of trial.'

In the lnctex to the above houk the tume is said to be 'adapterl' by Sir John Gross, but nothing further is stated as to its souree, and the original from which the adaptation was made has nut been discovered. In its rhythm and some of its phrases it bears a resemblance to a melody found in many of the German hymu books from i 527 onwark, generally associated with the words. 'Ach, wir' armen Siinder,' ete.

Bon Accord. I's. 2:6.

[The P'salms of Iavid, ete.], Aberleen, Elward Raban, 1625 .

Of this edition of the Seottish Book of Common Order only 
two copies are known, both wanting the title-page. The printer's name and the date are on the last page.

It contains fifteen common tunes in four parts, including the twelve of the Edinburgh edition of $\mathrm{I}^{6} \mathrm{I}$ (sce under 'Abbey'). The present is headed 'Ton Accord for the xii. Psalm.' It is harmonised in 'Reports' as at present (see under 'Aberfeldy'). It appears again in Hart's Edinburgh edition of ${ }^{6} 635$ without a name, and set to Psalm i 2, but there are some slight differences in the parts as compared with Raban's arrangement. Boston. Hy. Appx. 2.

L. Mason.

The Boston Handel and Haydn Society Collection of Church Music; being a selection of the most approved Psalm and Hymn Tunes. Third edition, I824.

This tune is namel 'Hamburg.' It is headed 'Gregorian Chant, Benedictus,' and set to the hymn 'Sing to the Lord with joyful voice.'

Brackley. Hy. 319.

F. A. J. Herver.

The Church Hymmary, I898.

Composed for this hymn.

Braylesford. Hy. Appx. 1.

II. J. Gaunthett.

Church Psalter and Hymnal, edited by Rev. E. Harland. Set to tunes by H. J. Gauntlett, i 869 .

Composed for this hymn.

Bredon. Ps. 149.

II. J. Gauntlett.

Church Psalter and Hymnal, edited by Rev. F. Harland. Set to tunes by H. J. Gauntlett, i 869 .

Set to the hymns ' $O$ where shall rest be found' and ' $A$ charge to keep I have.'

Bremen. Hy. 268, 331.

M. Vulpius.

Ein schön geistlich Gesangbuch. ... Durch Melehiorem Vulpium Cantorem zu Weymar. Jehna, r6og.

The melody appears as under, set to the hymn 'Christus der ist mein Leben.'
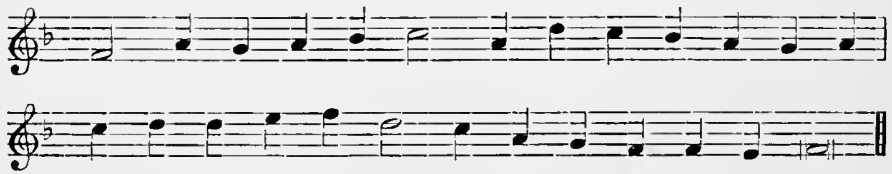
The present form of lines 3 and 4 is fouml in Criger's Praxis I'ietatis Melica, elition i 662.

Breslau. Hy. 41.

As hymnodus sacer. Zwölff Geistliehe anmuhtige unl theils newe Gesïnge. . . . Leiptzig, 1625.

The meloly, as under, is set to the hymn 'Herr Jesu Christ, meins Lebens Licht.'
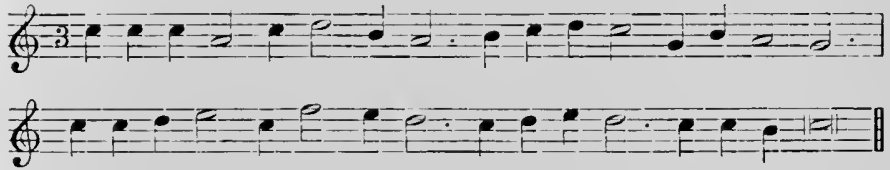

Later German books show variations in every line. The present form of the melody is that adopted by Mendeksohn in the oratorio 'St. Paul.'

Bristol. 1's. 38 .

The Whole liooke of I'salmes. . . composerl into 4 parts by sundry Authors. . . Newly correcterl and enlarged by Tho. Ravenseroft, I621.

Set to P'salms i 6 and 64, and named 'Pristoll Tune.'

Bryant. $11 y .446$.

II. Aicock.

The Church Hymuary, 1898.

Composed for this hymn.

Bucer. Hy. 276. P's. 150.

Cantica Laudis, ertited hy Lowell Mason and (r. J. Webb, I 850 .

The tune is said hy these elitors to be an arlaptation from Robert Schumann, but although it was submitted for ilentifieation to Madame Sehmmann and other experts, nothing has been found among Schumann's compositions from which it could have been ilerived.

Burford. P's. 39.

A Book of Psalmody, containing Variety of Tumes for all the Common Metres of the Psilms in the Old and New Versions, and others for Particular Measures.... all set in Four 
Parts, within such a compass as will most naturally suit the voices in Country Churches, yet may be sung in Three or Two without any Disallowances. By John Chetham, I 7 I 8.

Set to Psalm 42, New Version.

The tunes are without names, and no composers' names are given.

This tune is named 'Burforl' in Gawthorn's Harmonia Perfecta, I 730 .

In many modern collections 'Burford' is attributed to Henry Purcell, but there seems to be no evidence for this. Probably the earliest books in which it is so assigned are Cotterill's Christian Psalmody, I83I, and Novello's Psalmist, I835. The tume is found in a very large number of the eighteenth century psalmodies, ant in none is Purcell named as composer.

\section{Caithness. Ps. 40.}

The Psalmes of David in Prose and Meeter. With their whole Tunes in foure or mo parts, and some Psalmes in Reports. Whereunto is added many godly Prayers, and an exact Kalendar for xxv. yeeres to come. Printed at Edinburgh by the Heires of Andrew Hart. Amno Dom. 1635 .

This edition of the Scottish Book of Common Order contains thirty-one common tumes, the present being No. 29, headed 'Cathnes Tune.'

The edition is a most important one from a musical point of view. It is the only one in which the proper tunes, printed at the head of the psalns, are harmonised throughout; it contains a greatly increased number of common tunes; and it has, in addition, eight psalms harmonised in Reports.

The psalms are preceded by a preface 'To the gentle reader,' signed 'E M.' An investigation by Dr. David Laing has shown that these are the initials of Edward Millar, an Edinburgh musician, who graduated M.A. in the University there in I 627 .

In this preface Millar mentions the reasons which incluced him to undertake the work of editing the book, among them being 'an abuse observed in all churehes, where sundrie Tribles, Bases, and Counters set by diverse authors, being sung 
upon one and the sane Tenor, do diseordingly rub each upon another, offending both Musicall and rude cars.'

Calm. 11 y. 225.

J. F. Brivge.

The Church Hymnary, r898.

Composed for this lymm.

Cambridge New. T's. 41.

J. RAxidal.

A Collection of Psalm Tumes for Publick Wurship, by Stephen Adlington, D.I. Sixth edition, I 786.

The original arlangement, an in the above collection, is in three parts, ats follows:-
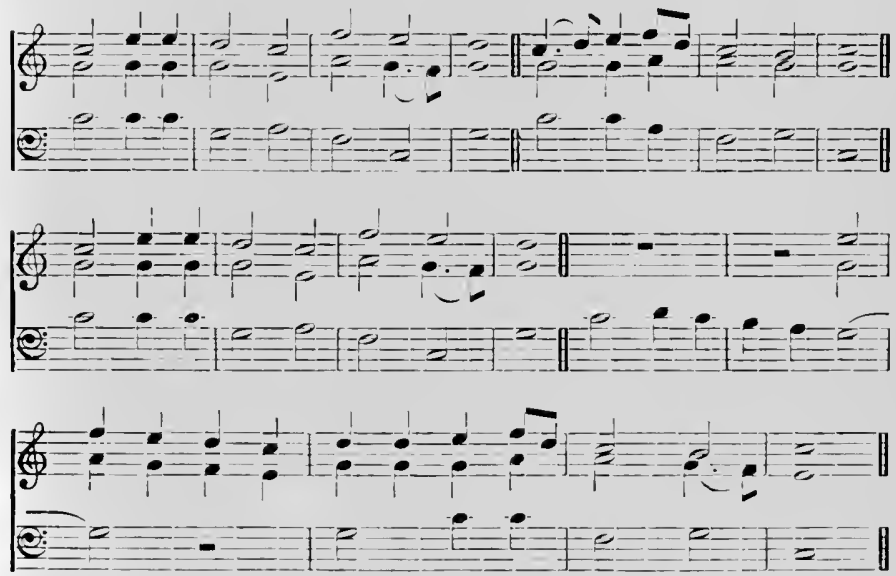

Campfields. $\mathrm{H}_{\mathrm{y}} .222$.

M. J. Moxk.

The Cliureh Hymuary, i 898 .

Composel for this hymm.

Cana of Galilee. $11 y .114$.

G. J. Finer.

The Song of P'aise ; or, Psalm and Iymm Tunes, collecterl and arranged by Vietoria kinus-Freke, 1876.

Composed for this hymm.

Cantate Domino. $\mathrm{Hy}$. 9 .

J. liarsBy.

The Ilymnary, i 872 .

Composel for this hymn. 
Capetown. Hy. 356.

F. FiLITz.

Vierstimmiges Choralbuch zunı Kirchen- und Hausgebrauch ... bearbeitet und herausgegeben von Dr. Friedrich Filitz, Berlin, [ 1847 ].

The melody is set to the hymn 'Morgenglanz der Ewigkeit' as under, the metre being 78.78 .73 .
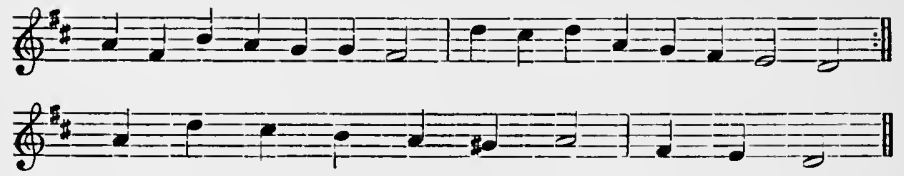

Carrow. Hy. 221.

A. S. Sullivax.

The Congregational Psalmist, edited by Dr. Henry Allon. Appendix, 1875 .

Composed for this hymn.

Casa Guidi. Hy. 310.

C. H. H. Parry.

The Church Hymnary, 1898.

Composed for this hymn.

Castle Rising. Hy. 238.

F. A. J. Hervey. The Supplemental Hymn and Tune Book, compiled by the Rev. R. Brown[-Borthwick], 1867 .

Composed for this hymn.

Lines 3 and 4 originally stood as under, but were afterwards altered by the composer to their present form.

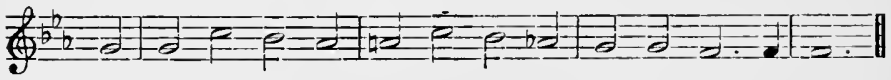

Castleford. Ps. 42.

Arr. by S. S. II esLer.

A Selection of Psalms and Hymns arranged for the Public Services of the Church of England, edited by the Rev. Charles Kemble and S. S. Wesley, i 864.

The tune appears in Dr. Wesley's European Psalmist, with the initials S. S. W., indicating that, though arranged by lim, it is not an original composition. The original has not been traced.

Certa Clarum Certamen. Hy. 86.

Church Psalter and Hymnal, edited by Rev. E. Harland. Set to tunes by H. J. Gauntlett, 1869. 
Set to the hymn 'Soltliers of Christ, arise.'

In the above book no composers' names or sources are griven for the tumes, and elitors of later books have assumerl that this: tune is an original composition by I)r. Gauntlett. It secms, however, to be an arrangement by him of the following German tune:-
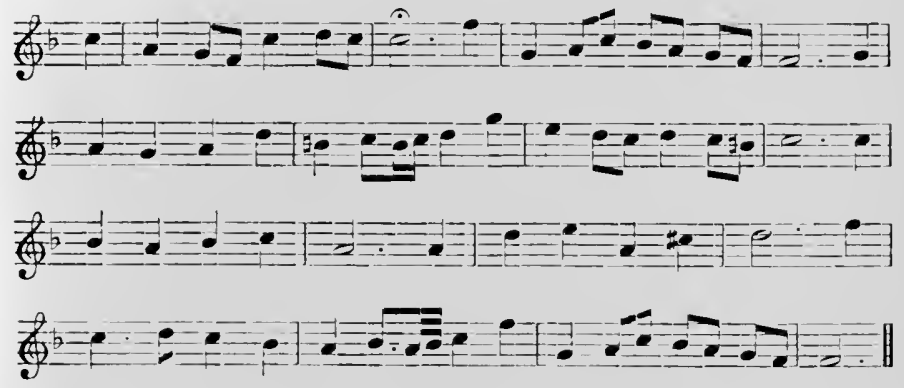

This melody appears in Mrsicalisehes Ciesang-Buch, Leipzig, I736, elited by (i. C. Schemelli. The preface states that the melodies were partly composed and partly arranged by John Sebastian lach, and Zahm is of opinion that the above melorly is Jach's composition.

Chalvey. Hy. 305.

I. G. HAYNe.

Hymns Anciont and Modern. Appendix, 1868.

Compresl for this hymn.

Charity. Iy: 24t.

J. STALER.

Iymus Incient and Molern. Appendix, I 868.

Composed for this hymn.

Chebar. $11 y .152$.

II. SIIART.

The Song of Praise; or, l'salm aml Hymm Tunes, colloced and arrangel by Victoria livans-Freke, 1876.

Set to the hymn 'There is an ancient river.'

Chenies. Hy. 232 .

T. R. MATTHEWS.

Composed for the hymm 'From Creenland's icy mountains,' and first publisherl in leaflet form about i 855 . It was then included in The Village Church Tune Book, compiled by the Rer. T. Richard Matthews, 1859. 
Cheshire. Ps. 43.

The Whole Booke of Psalmes with their wonted Tunes, as they are song in Churches, composed into foure parts.... Compiled by sondry authors. London, Thomas Fst, I 592.

One of a number of tunes which' are said to be 'newly added in this booke.' It is named Chesshire Tune, and is set to Psalm 146.

Child Service. Hy. 572 .

H. E. Button.

The Bristol Tume Book. Third Series, 189 I.

Composed for this hymn in 1886 for a Sunday School Festival.

Children of Jerusalem. Hy. 551.

The Tune Book to the Hymns and Chaunts for Sunday Schools, edited by John Curwen.

This book has no date, but the British MIuseum Catalogue gives 1842. The hymn and tune also appearer in "The Juvenile Harmonist: a Selection of Tunes and Pieces for Children, arranged for two trebles and a bass, by Thomas Clark of Canterbury,' [ 1843 ]. The present arrangement is by Dr. W. H. Monk.

Children's Song. Hy. 584.

H. WALTON.

The Church Hymnary, i 898.

Composed for this hymn.

Children's Voices. Hy. 519.

E. J. Hopkins.

Church Hymns with Tunes, 1874 .

Composed for this hymn.

Christmas Morn. Hy. 574.

E. J. Hopкiss. The Children's Hymn Book, edited by Mrs. Carey Brock, I 88 I.

Composed for the hymn 'The joyful morn is breaking.'

Church Triumphant. Hy. 22, 517.

J. W. Ellliott.

Church Hymns with Tines, 1874 .

The tune is set to three different hymns in the above book, but Mr. Elliott states that it was composerl, not for any of them, but for the hymn 'Again the Lord's own day is here.' 
City Bright. Hy. 5.5.

J. S. Tyler.

Songs of Love and Merey, 1876 .

Composed for this hymm.

The above bok was issued ly the Children's Special Service Mision, with which the composer has been connected since its fomlation in 1867 .

Clarence. Hy. 500.

A. S. Sthlimas.

Church lIymus with Tunes, 1874 .

Arranged for this hymn. l'art of the tume is an adaptation hy Sir A. Sullivan from one of his own compositions.

Clarion. Iy. 118.

MYLEs I), Fuster.

The Congregitimal Mission IIymmal, 1890.

Composed for this lyomn.

Cleethorpes. IIy. 604 .

T. R. MATTHEW:

The North Coates Supplemental Tune Book, 1874 .

Composed for the hymm 'We phongh the fields and scatter.'

Clevedon. Iy. 363.

S. S. WEsLEY.

A Selection of Psalms and Hymus arranged for the l'ublic: Serviess of the Chureh of Fugland, erlited by the Rev. Charles Kembri and S. S. Wesley, 1864.

Composerl for this hymm.

Cliftonville. $\quad$ Ir. 569.

F. C. MAKER.

The Congregational sumbay Sehool Mymmal, i Sgı.

Composed for this hymm.

Cloisters. Hy. 463.

J. IiARNBY.

Iymms Ancient and Moulem. Appentix, 1868.

Composed for this hymm.

Coburg. 11 r. Арpx. 5.

II.R.II. l'RIN'E ALBERT.

Congregational Church Music: A Book for the service of Song in the IIonse of the Lorl, i 853 .

The tume is thus reforrel to in the preface by the Rer. Thomas Binney: 'I must express my leep sense of obligation to Mis Royal Highmess Prince Albert, not only for the readiness with which he permitted the insertion of his tune (iotha, but for accompanying that permission with a copy of a Christmas 
hymn, which in the most gracious manner was placed at our disposal, and which is thus, with his authority, included in our collection.'

The tune is headed 'Christmas hymn, "Hark, the herald angels sing.",

Cœli Enarrant. Hy. 452.

R. P. Stewart.

Chureh Hymnal (authorised by the Irish Episeopal Church), I 874 .

Composed for the hymn 'The heavens declare Thy glory.'

Cœna Domini. Hy. 409.

A. S. Sullivas.

Church Hynus with Tunes, 1874 .

Composed for this hymn.

Colchester. Ps. 44.

A Compleat Melody: or, the Harmony of Zion. . . By William Tans'ur. (Preface dated September 29, I734.)

Set to Psalm I50, and headed 'Colchester Tune. Composed in Four Parts. IV. T.' The melody is as follows :-

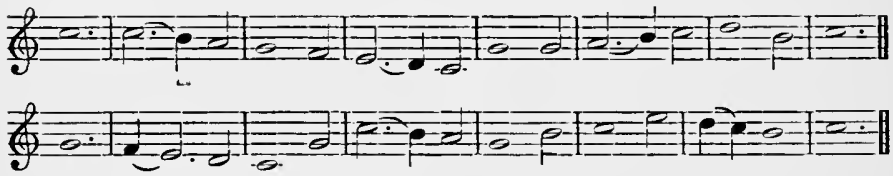

It is doubtful whether the tune is an original composition by Tans'ur, or was merely arranged by hin.

Coleshill. Ps. 45.

This is not an original tune, but is really a modified form of the tune 'Dundee' (q.v.). In the first edition of Wrilliam Barton's Book of Psalms in Metre, 1644, there is found a tune headed 'London long tune, proper for solemn ditties, and used everywhere.' The musie is full of evident misprints, but the tune bears elose resemblance to 'Coleshill.'

According to H. F. Dibdin (Standard Psalm Tune Book, I $85 \mathrm{I}$ ), the tune appears under the name 'Mejsell' in Edmund Ireland's Tunes of the Isalms in Two Parts, York, 1699, thus :- 


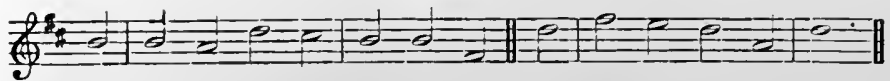

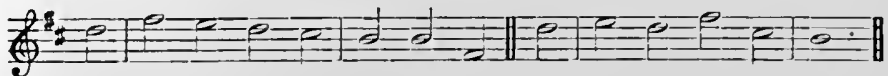

In Ireland's The Most Iseful Tunes of the P'salms, I 7 I3, it is named 'Ifull Tune,' the melody being as follows:-

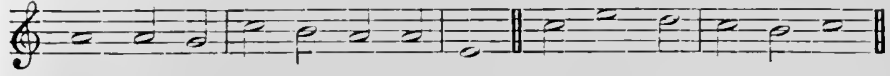

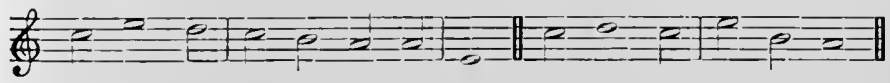

So far as has been yet ascertained, the earliest appearance of the tune in its present form is in 'The P'salms of lavid in Metre. Newly Translated. With Amendments. Ly William Barton, MI.L. Anl Set to the best Psalm Tunes, in Two Parts, viz. Treble and Bass. . . By Thomas Smith. Dublin, 1 706.' The tune is here printerl as follows, and called 'Dublin 'Tune,' the bass being given at the ent of the rolume:-
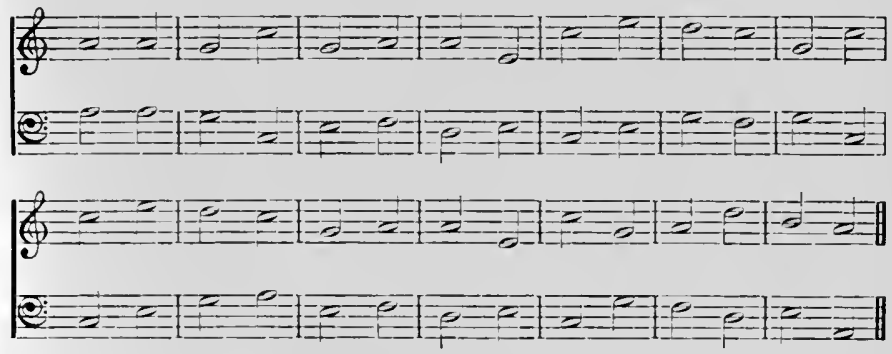

The curious misplacement of the bars is common to all the tunes in the book.

The name 'Coleshill' is attachel to the tune in ' $A$ Collection of Psalm Tunes in Four Parts. Fitted to the Old or New Versions. London, I7ı.' It is here set to Psalm i 6 , the melody being as follows :-
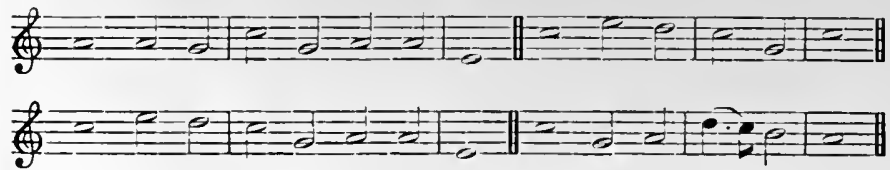
So far as has been discovered, its earliest appearance in Scotland is in Thomas Moore's Psalm Singer's I) lightful Pocket Companion, Glasgow, [1762], where the melocty is accompanied with the note, 'Sing Dundee Bass and Comter' to this Tune.'

Colwyn Bay. Hy. 211.

T. J. LINEKAR.

The Church Hymnary, 1898 .

Composed for this hymn.

Colyton. Hy. 442.

IT. H. Moxk.

The Chillren's Hymn Book, edited by Mrs. Carey Brock, I 88 I.

Composed for this hymn.

Come unto Me. Hy. 158.

J. J3. 1)YKES.

Hymns Ancient and Modern. Enlarged edition, I875.

Composed for this hymn.

Comfort. IIy. 434.

C. A. Garratt,

Hymnal of the Presbyterian Church in Canada, 1881 .

Set to the present hymn, and also to 'Come, ye disconsolate, where'er ye languish.' It was probably composed for the latter.

Comfort. Ps. 46.

I. M. Gibson.

Sacrerl Ifarmony, for the use of St. George's Church, Eclinburgh, i 820 .

Composed for Paraphrase 53, 'Take comfort, Christians.'

In the original, the key of the tune is $B$ flat, and there is adred a repeat of the last line, thus-

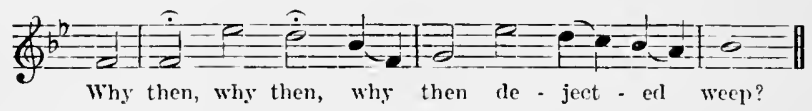

Commandments. Hy. 397. Ps. 4.

Pseaulmes cinquante de David, Roy et prophete, traduictz en vers francois par Clement Marot et mis en musique par Loys Bourgeoys. . . Imprimé à Lyon chez Godefroy et Marcelin Beringen. . . I 547.

The Metrical 1'salter of the French Protestant Church was compiled at Geneva, under the direction of John Calvin, and was the work of two writers, Clement Marot and Theodore 
Beza. Jegun with a collection of eighteen psalms printed at Strasburg in 1539, it was of grimlual growth, ant was not finally completed till 1562 . The origin of the melorlies to which the prilms were arlipterl is involved in some obscurity, but M. Donen, in his impertant work, Clement Marot et le Pautier Inguenot, has established the fact that

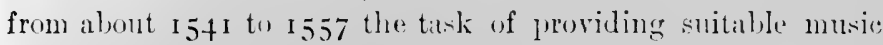
for the psialter was intrusterl by Calvin and the consistory to Lonis bourgeois, whose name appears in the above title. Which of the meluliess so provited are the compusition of Bourgeois, and which wore allipted by him from existing sources, it is now alment impossible to deternine. The present melody alpears for the first time in the above edition. It is set to the metrieal version of the Ten Commandments by Marot, and was retained in all subsequent editions. The same tune was set to the revion of the Commandments fornd in the linglish and seottish Reformation Pralm Bouks.

Commendatio. Hy. 6.5. J. I, J)YKES.

Hymms Ancient and Momlerm. linlarged elition, 1875.

Compored for this hymm.

Communion. IIy. $71,40 \pi$. I's. .5.

li. Mitiek.

The P'salus of thavil for the Lese of Parish Churelese. The Insic selected, Alliphed, and Composed by bilward Miller, Nus. Doc., I790.

The present tune is fomml seven times in this work. It is headed 'Part of the melorly taken from a hymn tune,' and is named 'Rockingham.' This name has been gemerally retained in Eughlish books. In seotland it seems to have appeared first in the collections edited hy R. A. Simith and John Wilson. It is there attached to J'alraphrase 35, and called 'Communion,' doubtless from the fact that this paraphrase is almost invariably sung on Communion occesions. In both these books the second note of the melorly in the second line is flattened, but this rearling has now been universally dropped in favour of the original.

Communion. Hy. Appx. 9.

S. S. Westey.

A Selection of P'salms and IIrmus arranged for the I'ublie 
Services of the Church of England, edited by the Rev. Charles Kemble and S. S. Wesley, i864.

Composed for the hymn 'Nearer, my God, to Thee.'

Compassion. Hy. 168.

F. NEEN.

The Congregational Psalmist Hymnal, edited by Dr. Henry Allon, r 886.

Composed for this hymn.

Compline. Hy. 101.

L. G. IIAYNe.

The Merton Tune Book: A Collection of Hymn Tunes used in the Chureh of St. John Baptist, Oxford, compiled by the Rev. H. W. Sargent, M.A. Edited and Arranged by the Rev. L. G. Hayne, I863.

Composed for the hymn 'O Saviour, bless us ere we go.'

Confidence. Ps. 6.

J. Clark.

The Divine Companion; or, David's Harp new Tun'l. Being a Choice Collection of New and Easy Psalms, Hymns, and Anthems. . . . The third edition, 1709. Edited by Henry Playford.

Set to Psalm i2 I. The tune is in key A, and the melody is the same as the present, except the last line, which in the original is as follows:-

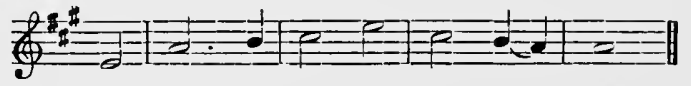

Consecration. Hy. 256.

G. M. Garret'.

The Hymnary, 1872.

Composed for the hymn 'Oft in sorrow, oft in woe.'

Consolation. Ps. 47 .

An adaptation from the theme of the Finale of Beethoven's Quintett, Op. I6.

Constance. Hy. 215.

A. S. Sullivan.

The Christian Hymnal. Five Hundred Hymns for the Chureh and Home, I873.

Composed for this hymn.

Contemplation. Hy. 445.

Mendelssohis.

'Lord, how long wilt Thou forget me?' Psalm I3. Music by F. Mendelssohn Bartholdy, [1840]. 
The present is the music of the Chorale, 'Lord, nyy Gorl, behold and hear me," No. 2 of the above work.

Copenhagen. Hy. 527.

E. Hartmans.

Ti aandelige Sange af Emil Hartmann, i860.

Composed for the Danish rersion of the present hymn. The present harmony was supplied by Sir J. Stainer.

Corde Natus. Hy. 32.

In the 'IImmal Noted, Part II., i 856,' this melody is given as 'from a XIS. at Wolfenbiittel of the xiiith century.' In the alssence of a more definite reference, and in riew of the enormous number of ISS. at Wolfenhuittel, it has not been found possible to verify this statement.

The present arrangement was made by Sir John Stainer for The Chureh Hymnary.

Corinth. Iy. 11, 164.

An Essay on the Clunch Plain Chant, 1782. (See nnder 'Adeste Fideles.')

This tune is in the second part of the work, entitled 'Part Second, containing severil Anthems, Litanies, P'roses, and Hymns, as they are sung in the P'ublic Chapels at London.' It is healed 'The Hymn at Benediction,' the words being 'Tantum ergo sacramentum,' etc. To this, as to nearly all the music in the rolume, no composer's name is attached, but many of the pieces are certainly by Samuel Webbe, and it is highly probable that he was the ectitor of the work. In his Mass in $\Lambda$, printed in $A$ Collection of MIodern Church Music, 1791 , and again in $A$ Collection of Irases. . . for the use of Small Choirs, 1792, this setting of the 'Tantum ergo' forms the elosing number; and it is again included in $A$ collection of Motetts or Antiphons. . By S. Wether, 1792. In the last volume many of the pieces are distinguished by having the name "Webbe' printed at the close, the inference being that those not so marked are not his composition. As the present is one of those without his name, it remains a doubtful point, whether it is an original composition by Webbe, or a melorly of older date arranged by lim. The present form of the tune 
is exactly in accordance with the original, with the exception of the seventh bar, which in all the above-named publications reads thus-

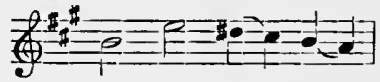

Corona. Hy. 88. Ps. 48.

E. R. BARKER.

Catholic IIymns. Set to Music by the Composer of Ilymns of the Eastern Church, [1868].

Set to the hymn entitled 'The Crown of 'Thorns,' begimning 'From circlets starred with many a gem.'

Courage, Brother. Hy. 273.

A. S. Suldivax.

Good Words, January 1872.

Composed for this hymn, and published in above periodieal as a solo with piano accompaniment. The present four-part vocal harmony was arranged by J. S. Anterson from the piano accompaniment, and appeared in The Presbyterian Hymnal for the Young, I 882.

Covenant. Hy. 302.

J. Stainer.

Hymns Ancient and Modern. Supplement, 1889.

Composed for this hymm.

Craigendarroch. Hy. 581.

F. A. J. Hervey.

The Chureh Hymnary, 1898 .

Composed for this liymn.

Crasselius. Hy. 6. Ps. 7.

Musicalisch Hand-Buch der Geistlichen Melodien ¿ Cant. et Bass. Hamburg, 1690.

The melorly, as under, is set to the hymn 'Wer nur clen lieben Gott liisst walten':-

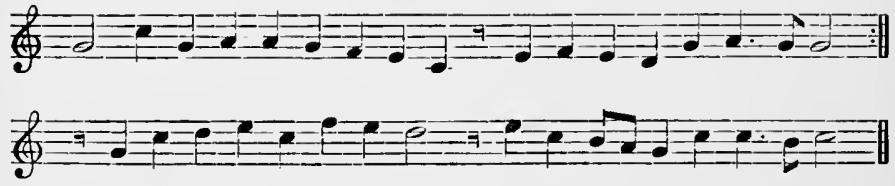

In Moore's Psalm-Singer's Delightful Pocket Companion, 
Glasgow, [ $\left.7^{62}\right]$, the tume appears in the following form, and is named 'Winehester' :-

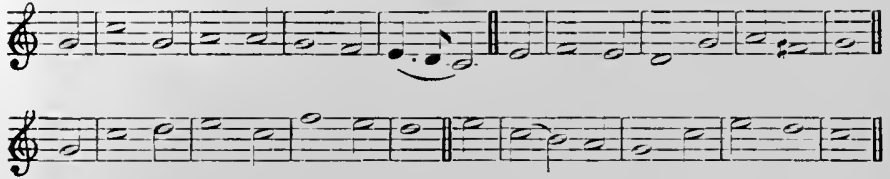

From this version the tune 'Effingham' seems to be derived.

Crathie. $11 y, 608$.

J. F. SRIDGE.

Under Lochnagar. Aberileen, 1894.

An Album, edited by Dr. P'rofeit, and published in connection with the bazan for the new parish chureh of Crathie. The tune was composerl for the hymm hegimning 'Accept of our aroming Thy Ifome of Praver, () Land,' written hy the Thke of Arogll (then Marquis of Lorme) for the above book. The tune was includerl in the Westminster Abbey Hymn look, 1897 , edited by sir F. Irridge.

Creator Spiritus. $1 \mathrm{IJ}_{\mathrm{y}} \mathrm{I37}, 629$.

J. STAINER.

The Chureh IIrmuary, 1898.

Composed for this hymm.

Crediton. Hy. 7t. 1's. 49.

T. Chark.

A Second set of Psalm Tumes adipted to the use of Comntry Choirs, [rima i 8 Io].

Set to Psalm s, new rersion, 'O Thon, to whom all creatures bow.'

The tune has no name in above collertion.

Credo. Hy. 124.

J. STAINER.

Hymms Ancient and Morlern. Enlarged edition, is75.

Composed for this hymm.

Crimond. P's. 50.

1). Grayt.

The Northern P'salter, orlitel by Wrilliam Camie, I872.

Croft. Is. 173.

Tr. Croft.

The Divine Companion; or, l)avid's Har'p new Tun'd. Being a Choice Collection of New and Easy Psahms, Hymns, 
and Anthems.... The third edition, I709. Edited by Henry Playford.

Headed 'A Psalm Set by Dr. Crofts. Psalm cxxxvi.' The melody in the original is as follows:-
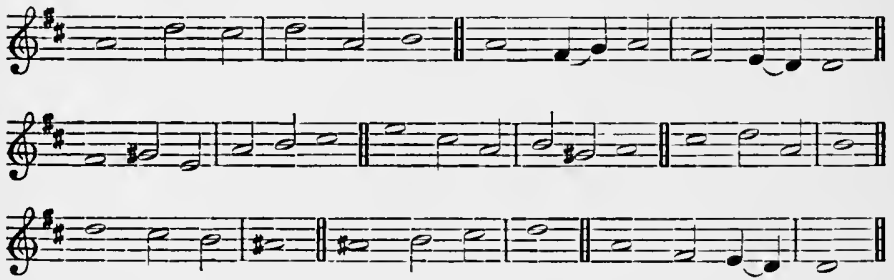

Cross of Jesus. Hy. 230.

J. Stainer.

The Crucifixion: A Meditation on the Sacred Passion of the Holy Redeemer. The MLusic by J. Stainer, i 887.

The work contains several hymns 'to be sung by the congregation.' The present tune is that set to the hymn 'Cross of Jesus, Cross of Sorrow.'

Crossing the Bar. Hy. 314.

J. BARNBY.

The Home and School Hymnal, 1892.

Composed for these words.

Crux Crudelis. Hy. 539.

A. L. Peace.

The Scottish Hymnal, i 885 .

Composed for this hymn.

Culford. Hy. 256.

E. J. Норкікs.

The Temple Church Choral Service, edited by Edward John Hopkins, I867.

Set to the hymn 'Songs of praise the angels sang.'

Culross. Ps. 51.

[The Psalms of David, etc.] Edinburgh, Printed by the Heires of Andrew Hart, I6 34 .

This small edition of the Scottish Book of Common Order (of which the eopy examinel wants the title-page) contains sixteen 'Common Tunes in foure parts,' ineluding all of those which appeared in the edition of $16 \mathbf{r}_{5}$. The present is No. vi., and is headed 'Culros Tune.' 
Cyprus (Berlin). IIy, 183.

Vollstindige Psalmen und geistliehe Lieder. . . Bremen, I639.

The melody appears as umber, set to the hymn 'Heil'ger Cieist, du 'Tröster mein.'

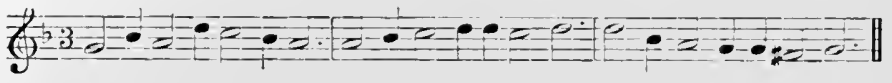

In Cruger's Gesanghuch, r6fo, it is set to the same hymm, but in the following form :-

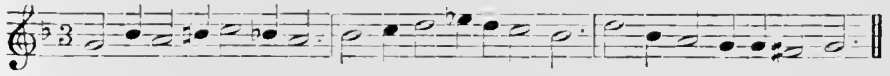

Dalkeith. It 176.

T. Hewlett.

The St. Alham Tume Bumk, [rira r S66].

Composed for the hymm ' Mrile with ne.' It was set to the present hymm, with the sanction of the composer, in the Appendix to Hymus Ancient and Modern, r 868.

Damascus. 1 y. 309.

E. R. BArker.

Hymms of the Einstem Church. In Compressed sione, for Four Vuices. First series, [1864].

Contains six of Dr. I. M. Neale's translations, with mus ir l,y Mrs. liarker, the present hymm and tume being No. 3.

The tunes were composed and fublished at I)r. Neale's special desire.

Darwall. Hy. 89. I's. I7t.

J. I)ARWALI.

Williams's New L'niversal I'salmorlist, г 7ъo.

Composed for P'salm $1+8$, new version.

The Rev. Henry I'arr, in his Churrh of England I'salmody, states that the Rev. John I)arwall 'composed Tumes in two parts to the whole I 50 I'salus, the autograph of which is now in the possession of his gramdson, the Rev. Leicester 1)arwall.'

Day by Day. Hy. $5: 4$.

E. S. CArter.

Church Hymus with Tunes, 1874 .

Composed about r 865 for the lịmn' Day by day we magnify Thee.' 
Day of Praise. Hy. 370.

C. Steggall.

The Supplemental Hymn and Tune Book, compiled by the Rev. R. Brown-Borthwick. Third edition with new Appendix, [1 869].

Composed for this hymm.

Day of Rest. Hy. 405. J. IV. Elliott.

Chureh Hymms with Tunes, 1874 .

Composed for the hymm ' $O$ day of rest and gladness.'

In Hymns Ancient and Modern, edition 1875, it was set to the present hymn.

Deerhurst. Hy. 422, 443, 482.

J. Langran.

Psalms and Hymns adapted to the Services of the Chureh of England, with accompanying tunes, selected and revised by Johu Foster, I 863 .

This work, which had appeared without music in 1836 , was erlited by the Rev. W. J. Hall, and was commonly known as the Mitre Hymn Book, from the figure of a mitre which appeared on the boards.

The 1863 edition is a cut-leared book, and the tune 'Deerhurst' is referred to the hymns 'Lord of heaven and earth and ocean' and 'May the grace of Christ our Saviour.' It was composed in 1862, and at a Choral Festival in Peterborough Cathedral was set to the hymm 'Hark the sound of holy voices.' This adaptation has been followed in Hymns Ancient and Motern and other collections.

Delhi. Hy. 271.

E. F. Rinibault.

Choral Harmony with Supplement: A Collection of Tunes in short score for four voices . . I Iy the Rev. Peter Mauriee, D.D., [1858].

Set to the hymn 'From far I see the glorious day,' and dated 1857 .

Dessau. Hy. 398 .

J. R. AILLE.

Nene geistliche auf die Sonntage durchs gantze Jahr gerichtete Andachten . . . Miihlhausen, 1664. 
In this collection the original form of the melorly appears as under, set to the hymm 'Ja, er ist;, das Heil der W'elt.'

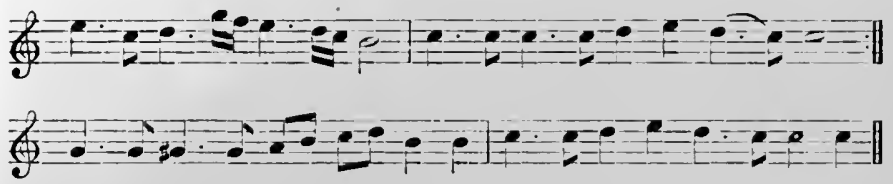

Later Gorman eollections contain the same mekmy with numerous variations. Of the present arrangenent, line I is fomkl in speer's (iesangluch, I691 ; line 2 in Fiese's (iesangbuch, I7 2 ; and lines 5 and 6 in that slitest hy Vutter in I 709 .

Deus Misereatur. Iy. 1к.5.

Il. 1) Fuster.

'The Chureh llymmary, 898 .

Compresed for this hymm.

Deus Pacis. $\mathrm{II}_{y}, 621$.

(i. Joserit.

Heilige Serelenlust mler Geistliche Hirten-Iierler . . von Joham Angelo silesio, Lnd rom Herren Georgio Josepho nit

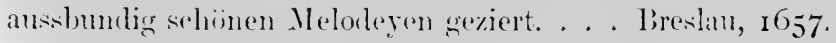

Harmonised by Sir John Staner for The Church Ilymnary. The meloly, with one trifling ehange, is the same as the original in the alove work, where it is set to the hymm "Keine Schein-

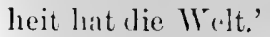

Diademata. II. 95.

(x. J. Filvey.

Iymms Ancient and Nodern. Aplentix, r868.

Composed for this hymm.

Dies Iræ.

J. Li. J)YKEs.

IIymms Ancient and Morlem, 1861.

Composed for this hymm.

Siren tumes hy Dr. Hylies appeared in this, the first erition of llyms Ancient and Morlern. 'The tunes are 'l leses Irre,

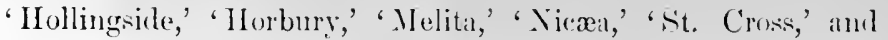
'St. Cuthbert.' They were sent to the elitor, I)r. Wonk, with a letter dated Oetober I 2, r860, in which I)r. Dykes says: 'I venture.. . to send a few Ms. tmes for your inspection, thinking it possible that some of them might do 
for your forthcoming book ... The "Dies Iræ" has given me much anxious thought. I am convinced that no single unvarying melody will bear to be sung to it throughout, without becoming thoroughly wearisome, and somewhat marring the grandeur of the words. The slight variations which I have introduced do not add to the difficulty of the composition (I have been most anxious to keep it as casy as I possibly could, consistently with the necessities of the words), but I think they will be found to relieve the hymn considerably.'

Dies Tenebrosa. Hy. 57.

J. B. Drkes.

The Song of Praise; or, Psalm and Hymn Tunes, collected and arranged by Victoria Evans-Freke, i 876 .

Composed for this hymn.

Dijon. Hy. $\Lambda$ ppx. 4.

Lieder-Buch für Kleinkinder-Schulen . . . Herausgegeben von Theodor Fliedner, 1842 .

The melody, as under, is set to the words 'Niide bin ich, geh zur Ruh.'
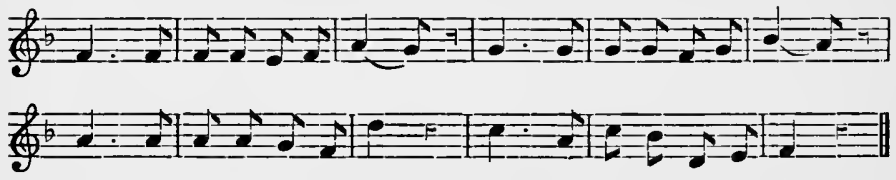

Diligence. Hy. 261.

L. MASON.

The Song Garden, i 864 .

Composed for this hymn.

Dix. Hy. 35.

C. Kocher.

Stimmen aus dem Reiche Gottes ... herausgegeben von Courad Kocher. Stuttgart, $18_{3} 8$.

The melody appears, as under, set to the hymu 'Trener' Heilanıl, wir sind hier.'

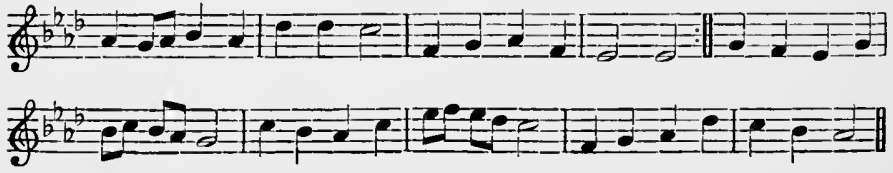


Dominus Misericordiæ. IIy. 103.

J. Stainer.

The Congregational Mission Hymnal, I 890.

Composed for this hymm.

The tune also appeared the same year in the enlirgend edition of The IIymnal Companion.

Dominus Regit Me. IIy. :19.

J. I. DYKE:

IIymns Ancient and Molem. Appenlix, r868.

Composed for this hymn.

The hymn and tune were sung at I)r. Dykes's funeral on 28 th January i 876 .

Dominus Vobiscum. 11y. 504.

A. Sumerteli.

The Chmreh Hymnary, isg8.

Composed for this hymm.

Doncaster. Hy. 243, 425.

S. WESLEY.

l'salms and Iymms for the Service of the Church . . . Sielected, adapted, composed, and arranged hy J. J3. Sale, I8.37.

Set to two psilms from the New Version, namely, l'salm $3^{1}$ and P'salm $5 \mathrm{r}$, liart 2.

Original name of the tune is 'Sethlehem.'

Dresden. $\mathrm{H}_{y} .498$.

J. А. P. S'chulz.

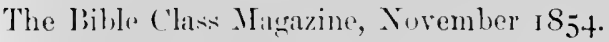

Entitlen 'Thanksgiving IIymun. Arrangerl from .J. A. I'. Sichulze. Words trunslated by Rer. S. F. Smith.' The present hymn is a translation ly Mlisw .J. M. Camploll of the same original. To information is given in the abrve magraine as to the original music by sichuly from which the arrangement was mate, and although a large numlere of his songs amb other works have been examined, nothing at all resembling it has been fomd. The metre of the refrain in the original German Iroem thes not suit the present tune, so that the latter could not have been written for it, but in a Gesangbuch published at Dortmund in I 893 , the hymn appears set to this tune, with the words of the refrain altered to suit it.

Duke Street. Hy. 438. P's. 8.

J. Hatton.

A Select Collection of Psalm and Hymn Tunes ... By the late Henry Boyd, Teacher of Psalmody, Glasgow, 1793. 
The composer died in I793, but the tune loes not seem to have appeared in any collection prior to the above. It is there headed 'Adlison's igth Psalm,' no composer's name being given. In Euphonia, a collection of tunes, edited by $W^{\prime}$. I)ixon, and pulblished in Liverpool about $\mathbf{8} 80_{5}$, it is found uncter its present name, and attributed to Hatton.

Dundee. Ps. 52.

The former [second] Booke of the Musicke of M. William Damon, late one of her maiesties Musitions : conteining all the tunes of David's Psalmes, as they are ortinarily soung in the Chureh : most excellently by him comprosed into 4 parts. In which Sett the Tenor [highest part] singeth the Church tune, I59I.

In this book 'Dunclee' appears for the first time in the form of a psam tune, but it is probable, as has been pointed out by the Rev. H. Parr, that it is an adaptation from one of the tunes in Christopher Tye's Actes of the Apostles, 1553. (See under 'Gethsemane.') The tune in question is that set to chapter iii., the treble being as follows:-
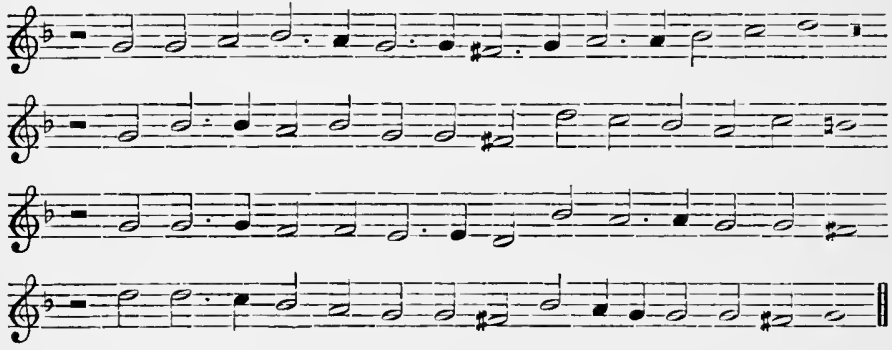

Damon's work consists of eight separate books containing two complete settings of the tunes, each in four parts, namely, Cantus, Altus, Tenor, and liassus. In one of these sets, called on the titles the 'former booke,' the melocly is in the Tenor; in the other, called the 'second booke,' it is in the Cantus. No complete set of either of these is now known, but it may be of interest to give in score the Cantus, Altus, and liassus (the Tenor being missing) of the present tume as they appear in I)amon's 'former booke.' The tune is set to 1'salm 116 . It 
HISTORIC.II

47

will be observed that although the 'former books' is that in which, according to the title-page, 'the Tenor singeth the Church tune, get in this particular case the melody is in the Cantus part.
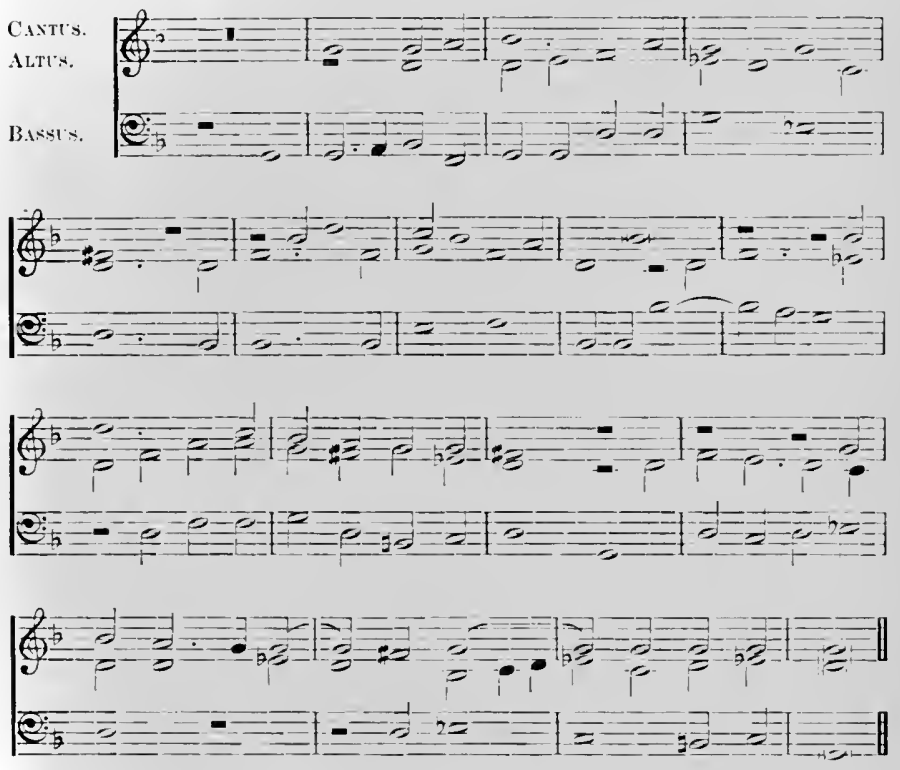

The tune is next form in 'The Whole Soke of Psalms with their wonted tunes. . . Wherein the Church tues are carefully corrected, and theremin allied other short tunes usually song in lomblom, and other places of this Revalue. . . Imprinted at London by Thomas list, 1592.'

In a table at the end of this volume the tune is incluterl among 'those tunes newly adored in this hoke.' It is set to Psalm 16 , the harmony being by (i. Kirby. The melody is as follow: :-

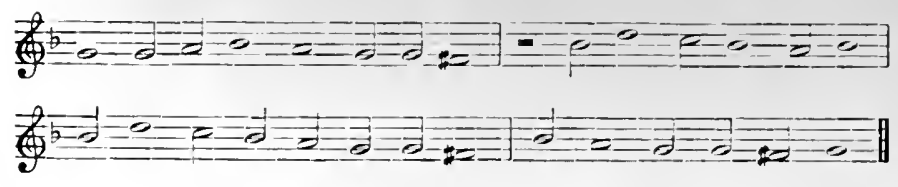


No name is here attached to the tune, but in three subsequent editions of the same book it is called 'Suffolk Tune.' In Ravenscroft's Psalter, I621, it appears four times, and is named 'Windsor or Eaton,' being classed in the Index among ' English tunes.' The name 'Windsor' is that by which it has eontinued to be known in England. The earliest appearanee of the tune in Seotland is in the edition of the Book of Common Order, printed by $A$. Hart in 1615 . It is printed, as under, among the Common Tunes, and headed 'Dundie Tune.' (See under 'Abbey.')

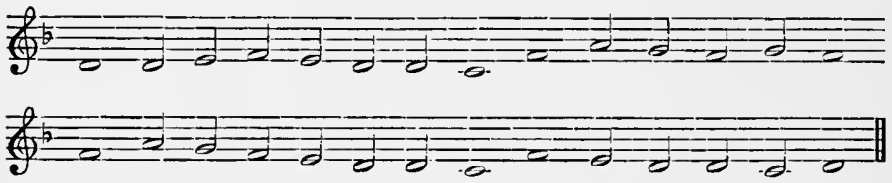

In Raban's edition, $16_{33}$, the sharp seventh is introduced at the penultimate note, and in that of 1635 the aecidental is also inserted at the last note of lines $I$ and 3 . The form of the second line in the above is found in nearly all Scottish books down to the early part of the nineteenth eentury. Since then the present form has become general.

Dunfermline. Ps. 53.

The CL. Psalmes of David, in Prose and Meeter: with their whole usuall Tunes, ete., Edinburgh, ${ }^{6} 6{ }_{5}$.

One of the 'xii. Common Tunes' which appeared in this edition of the Seottish Book of Common Order. (See under 'Abbey.') The first appearance of the tune in an English psalter is in Ravenscroft's Whole Booke of Psalmes, I62I, where it is classed in the Index as a 'Seottish tune.'

Durham. Ps. 54.

The Whole Booke of Psalmes. . . . composed into 4 parts by sundry Authors. . . . Newly corrected and enlarged by Tho. Ravenseroft, $162 \mathrm{r}$.

Set to Psalms 28 and 76 , and elassed as a 'Northern Tune.' It is included among the Common Tunes in the 1635 edition of the Scottish Book of Common Order. 
Eastburg. $11 y .171$.

G. C. Maита.

The Clumeh of linglind Irymual, r 895.

Composed for the hymm 'U Master. When Thon callent.'

Easter Hymn. Ily. 7 .

Iyra I arilica, w a Collection of l livine somers and IIrmus, partly New Composel, party Trunslated from the llish German and Latin Iymus; and set to easy and pleasint Tune, I 7 OS.

The hymn and tune appear as miler, headed 'The Resurection'-

$F^{2}:=\square \square$

Jes - us Christ is risen to dlar, nal - le- lial - ke lu - jah :

9:5:-0:0010

$\mathrm{Q}=\mathrm{O}$

Our tri-umph-ant IIn - Iy - lay, lial - le - lial - le - ln - jah !

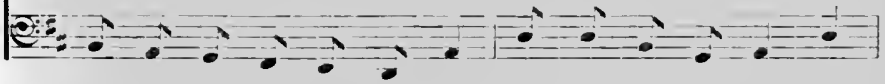

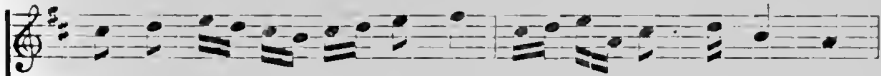

Who to late - Iy on the Cross, IIal - le - Ilul - le - In - jah !

:

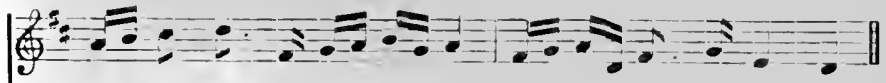

Suf - fermi to re - leem our lose, Inal - le - II:al - lk - In - jahn!

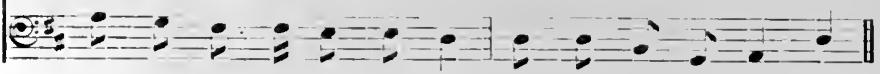

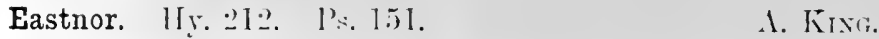

The Bristol Tune lbok, 1863.

Eden. Hy. 346.

O. M. Feiluex.

A Selection of P'silm and Ifymn Tumes, edited and arranged by L. II. Thorne. Linlarged edition, [I 863$]$. 
Set to the hymn 'Go forward in your course, ye armies of the sky.' The harmony is by Mr. Thorne.

Eden. Hy. 42. Ps. 55.

II. H. Havergat.

A Hundred Psalm and Hymn Tumes, 1859.

The tune was composed in 1845 , and may have been published in America about that date, as Dr. Lowell Mason, in a letter to the composer, dated April 30, 1847 , refers to the tune having been sung by his choir.

Edina. Hy. 240.

II. S. OAKELEY.

Hymns Ancient and Modern. Appendix, r 868.

Composed for this hymn.

Edinburgh. Ps. 56.

H. SiART.

The Hymnary, i 872 .

Composed for the hymn 'From lands that see the sun arise.'

Edom. Hy. 94.

A. L. Peace.

The Scottish Hymnal, $188_{5}$.

Composed for this hymn.

Effingham. Ps. 57.

Musicalisch Hand-Buch der Geistlichen Melodien ì Cant. et Bass. Hamburg, I69o.

See under 'Crasselius,' of which this tume is a modification.

Ein' Feste Burg. Hy. 464.

M. Luther.

This melody, and the hymn to which it belongs, have always been attributed to Luther. They are beliered to have first appeared in 'Geistliche Lieler . . . J. Klug, Wittemberg, 1529,' but no copy of this work can now be found. In an edition of the same work dated ${ }^{1} 535$, and in 'Kirche Gesenge, Niirenberg, I 53I,' the melody is found as follows :-
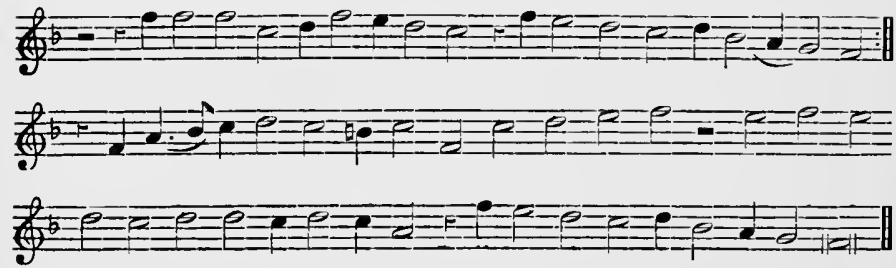
Eirene. Hy. 475.

F. R. Hatergat.. Havergal's Psalmody, edited by F. R. Havergal, 187 r.

Eisenach. Hy. 56.

J. H. SCIIELS.

First published on a single sheet entitled "Trost-Liedlein iiber den seligen ILintritt der Frawen Margariten, des Herrn Caspar Werners. . . I Iausfrawen . . . Coniponirt und MLusicirt von Johan-IIerman Schein, I628.'

It was incluled in the second edition, 1645 , of Cantional oder (iesangbuch $\Lambda$ ugsburgischer Confes:ion, edited by Schein.

The hymn for which it was composed is also, as indicated in the above title, by Schein, and begins, 'Machs mit mir, Gott, nach deiner Giit.'

Elgin. Ps. 58 .

[The Psalms of Davirl, ete.], Aberdeen, Edward Raban, 1625 .

(If this edition of the Scottish liook of Common Orler only two copies are known, both wanting title-page. The printer's name and the date are on the last page.

It contains fifteen common tunes harmonised in four parts, 'Elgin' being No. it.

Elim. Hy. 227.

IV. II. Callcott.

Psalms and Hymns for Divine Worship, 1867 .

Composed for this hymn. The original name of the tune is 'Rest.'

Ellacombe. IIy. 538 .

Vollstïndige Sammlnng der gewöhnlichen Melorlien zum Mainzer Gesangbuche . . . von Xav. Lucl. Ifartig, Mainz, [ rirca 1833$]$.

Set to the hymn 'Ter du im heil'gen Sakrament.' The melocly has set above it the date 1700 , but Dr. Baiumker states that Inartig is very ineorrect as to the sources of tunes, and he does not believe the present melocly is older than the beginning of the nineteenth century.

Ellers. Hy. 617.

E. J. IIOrkins.

The Supplemental IIymn and Tune Took, compiled by the Rev. R. Brown-Borthwick. Third edition, with new $\Lambda_{\text {ppendix, }}$ [1869]. 
Composed for this hymn, and arranged for voices in unison, with organ accompaniment, the latter being raried in each verse. The present four-part arrangement appearel in the Appendix to the Bradford Tune Book, edited by Samnel Smith, [1872]. The following note is appended:-'The above four-part rocal arrangement has been kindly prepared by the composer, at the request of the editor, specially for this work.' Another four-part arrangement appeared in Chureh Hymns, I874, and in Dr. Allon's Congregational Psahmist, $18_{75}$. In the latter book the arrangement is stated to be by Sir A. Sullivan.

Ellesmere. $\mathrm{Hy}_{\mathrm{y}}$. $15 \%$.

A. R. Reinagle.

The Praise Book, being 'Hymus of Praise' with accompanying tunes. By William Reid, M.A. Harmonies written or revised by Henry Edward Dibdin, 1866.

The tune is set to the hymn 'Master, we would no longer be,' and the Index states that it was 'sent by the composer for this work.'

Ellingham. Hy. 208.

S. S. Wesler.

A Selection of Psalms and Hymns arranged for the Public Services of the Church of England, edited by the Rev. Charles Kemble and S. S. Wesley, 1864.

Set to the hymn 'Father of Hearen, in whom our hopes conficle.'

The rhythm of line 2 has been slightly altered to suit the present hymm.

Elsenham. Hy. 603.

J. D. MACEY.

The Congregational Sunday School Hymnal, 1891.

Composed for this hymn.

Elvet. Hy. 155.

J. D. Drkes.

The Congregational Hynn and Tune Book, editer by the Rev. R. R. Chope, 1862.

Composed for the hymn 'Spirit of Wisclom, guile Thine own.'

Elvey. Hy. 100.

G. J. ELveY.

Choral Harmony, with Supplement: 1 Collection of Tunes in 
short score for four voices. . . Iy the Rev. Peter Maurice, I).I)., [ [ $\left.s_{5} 8\right]$.

This tune is there named 'Tindsor Cante, and is set to the hymm 'All language must he faint, The blesterluess to paint.'

Ely. Hy. $7,46,381 . \quad$ Ps. 9.

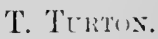

1 Collection of Psalm amel Hymn Tumes . . forming the first part of the Ponple's Music book, edited hy James 'Turle and Edward Taylor, is $8+4$.

Set to the Tate and liraly version of Psiln 100 , "With one consent let all the earth.'

Original name of the tune is 'St. Catherine.'

Emmaus. Hy. 2-8ะ.

J. listisy.

I'sahns and Iymns for Public Workhip, with aplropriate Tunes, erlited hy J. Turle, 1863.

Compred for the hymn 'The day, O Lord, is spent.'

Epiphany. 11!. 423.

E. J. Hopkiss.

The Conspregational I yrmm and Tune book, extited by the Rer. R. R. Choper, is62.

Compreal for the hymn "lirightert and bent of the suns of the morning.'

Epworth. 1'‥59.

C. MESLEY.

The l'silmist: A Collection of Psaln and lfymn Tunes, alited by Vincent Norello. I'art III., is $s_{3} 8$.

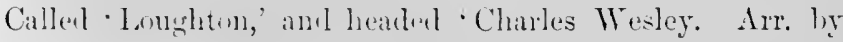
S. Wesley.'

Erin. IIy. 145, 400. Ps. 60.

Churdh Ilymual (anthorisen by the Irish Episcopal Chureh), $187+$.

In the lingraphical Index to the above IIymal, compiled by Iajor Crawforl, it is stater that this is 'one of the tumes collected by the lite $\mathrm{Ir}$. George Petrie in the remote parts of Irelanl, and believel by him to be a hymm of the Ancient Irish Chureh.'

The first two lines of the melorty have been slightly altered 


\section{5+ THE MUSIC OF THE CHLRCH HYMATRY}

from the resion published by Dr. Petrie, which is as follows:-

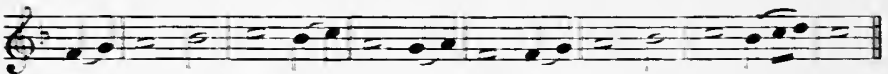

Ernstein. Hr. 55\%.

T. F. הNIFT.

The Methodist Sundar School Tune Berk. ISSI.

Compoed for the hrmn 'summer suns are gluwing."

Eternity. Hr. 3:?.

¿. $\therefore$ MEIES.

The Song of Praise: or. Psalm and Hrmn Tunes, collecent and arranged br Victoria Erans-Freke. is;6.

Composed for the hrmn - When the dar of wil is done."

Etiam et Mihi. Hr, Isa.

T. F. TY⿱乛龰Es.

The Hrmnal Companion to the Bowt of Common Prayer. second edition, Is 7 .

Compoed for this hrmm.

Eton. Hr. 16:.

T. HARSEY.

The Congegational Psalmis: Hrmmal, edied or I'. Henry Allon, isSó.

Composed for the hrmn - Come, re sinness mon and wretched.

Eucharistica. Hr. 414.

T. I.Aignas.

The Jem Mite-Hrmal. arawed w the services of the Church of England, with acconganing Tunes. IS-5.

Composid for inis hrmu.

Eran. Hr. 144. 174. Ps 61.

IV. H. HarEgent.

The crimal of this whe is a serting oy Mr. Haregal.

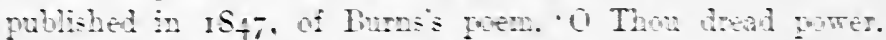
who reign"s atwre. The melonis is as follows:-
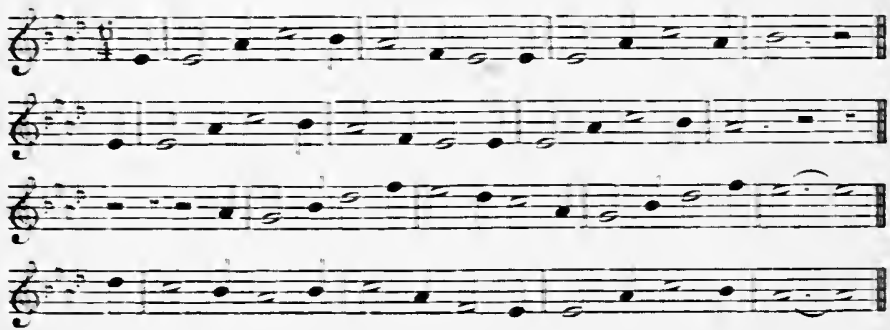


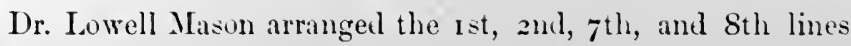
as a psalm tune, and published it in the New Carmina Sacra, I $S_{50}$, unler the name 'Kra,' with the initial 'II.' as composer.

Mr. Havergal diel not approve of this, and in 1870 he rearranged the tune, and wrote thus regarling it: 'As the American arrangement was a sill estrangement, I have reconstructed the tume after a more correct form.'

In the arrangement hy the composer each line berins and ends with a semibreve. Except in that particular, the composers rersion has been athered to in The Church Hymary both in resigect of melonly and harmony.

Evangel. I's 139.

Church Hymms with Tunes, IS $7+$.

Set to the hymm "While shepherds watched their flocks by night,' and called an '()lil Carol.'

It reems, however, to be founder on a setting composed by (r. W. Fink in $1 S_{+} 2$ of the song by M. C'landius hegiming 'War einst ein Rieso Goliath.' The meloly of this song is as follow: :-
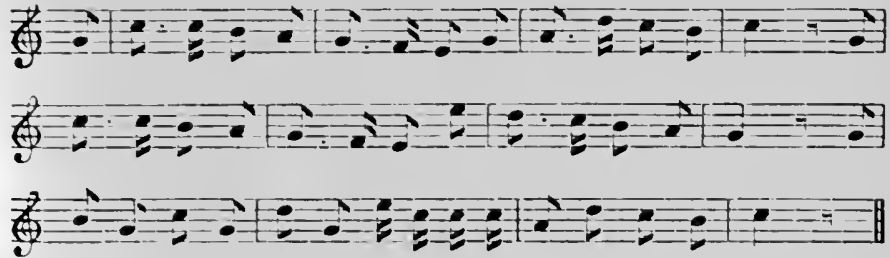

Evelyn. Hy, 149.

A. S. Sellivis.

Church Hyms with Tunes, is 7 .

Set to the 'Litany of the Passion,' and also to the hrum 'In the hour of my distress.'

Evening Hymn. H!: 3.)l.

T. Til.tis.

The whole Psalter translated into English Yletre, which contarneth an hundreth and tifty Psalmes.

This book bears neither date nor author's name, hut it is known to be the work of Matthew l'arker, Arehbishop of Canterbury, and was printed probably ahout $1_{5} 61$.

At the end of the book are nine tumes by Thomas Tallis, set 
in four parts (Meane, Contratenor, Tenor, and Iass), with the following note:-'The Tenor of these partes be for the people when they will syng alone, the other partes, put for greater queers or to such as will syng or play them privately.' The present is the eighth of these tunes, and is referred to P'salm 67. The melorly in the original is the same as at present, exeept that each lime is repeated before the next is introduced. The tune starts in the Tenor, the canon being in the lighest part or 'Meane.' The present four-line form appears in Ravenscroft's Whole Booke of I'salmes, I62I, where it is set to 'A Psalme before Morning Prayer.'

Evening Prayer. 11y. 601.

J. S'TAINER.

The Church Hymnary, isg8.

Composed for this hymm.

Eventide. $\mathrm{Hy}_{y} 365$.

W. H. Monk.

Hymus Ancient and Modern, r S6r.

Composed for this hymm.

It is said that Dr. Monk composed this tme in about ten minutes, while a pianoforte lesson was being given in the same room.

Eventide. Hy. 372.

II. SuART.

The Song of P'raise; or, Psalm and Hym Tunes, collected and arranged by Vietoria Evans-Freke, I 876 .

Composed for the hymn 'The Lord be with us as we bent.'

Ever Faithful. Hy. 17.

Chureh IIymns with Tumes, I874.

Composed for this hymn.

Everton. IIy. 164.

The Congregational Chureh Hymmal, i 887.

Composed for this hymn.

Everton. Hy. 90.

A. S. Sullivas.

Psalms and Hymns for Divine Worship, I 867 .

Set to the hymm 'Mighty God, while angels bless Thee.'

Ewing. Hy. 334.

A. EWIng.

Published on a single sheet in ${ }_{5} 8_{53}$.

Composed for the section of Bernard's hymn beginning 'For 
thee, $\mathrm{O}$ dear, dear country. The tme was origrinally in triple time as follows:-
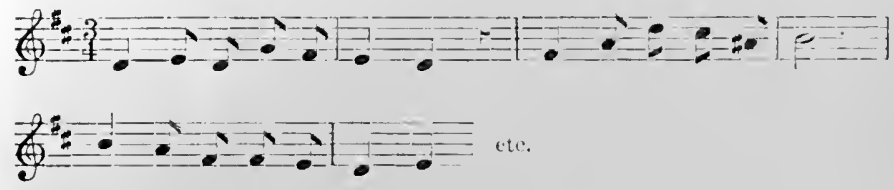

It alperars in this form under the name 'st. Jerles' in ' $A$ Mammi of l'salm and Hymn T'unes . . e elited by the lron. and Rev. J. Grery, 1857 .'

The first apprarane of the tume in the present form was probably in Hymus Ancient and Molern, IS6I, where it was set to the present worls.

Writing in 1861. In. Neale silist: "I hareso often been asked to what tume the work of liemand may be shos, that I may here mention thit of Mr. Ewing the arliest writson, the best known, and with childern the most popular; no small proof in my estimation of the gooriness of churcle music.'

Faber. 11y. 16\%.

S. Micuck.

The Chureh II ymuary. 1898.

This tune was mot slectidly compereel for this hymu, hut was

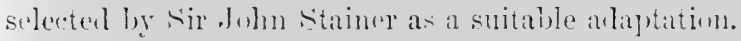

Fairfield. P's. 16.5.

I'. IA Tromis.

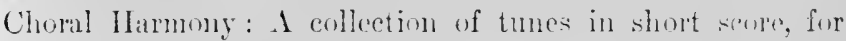
four voices, a companion to Metrieal Verwons of l'salms and

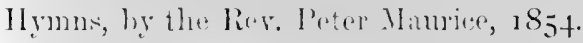

inet to the hymn '(iive to the winls thy fears,' and marked 'Contributed for the work.'

Faith. Hy. 51, 22:3. P's. 6.2. J. J. WYKES.

Psalms aml Mymmi for Livine Worship', 1867.

It is not certain for what particular hymu (if any) the tume was composed.

Fareham. Iy. 368.

J. Fioss.

The Iymmiry, 1872 .

Composel for the hymn 'I Lift "l' the Adrent strain.' 
Farrant. Ps. 63.

Adapted from the anthem 'Lord, for Thy tender mercies' sake,' usually attributed to Richard Farrant, but by some writers to John Hilton.

Felix. Ps. 64.

The Hallelujah, edited by Lowell Mason, 1854 .

The tune is founded on the following phrase in Mendelssohn's oratorio 'Christus.'

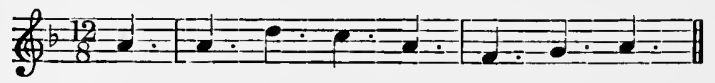

Feniton Court. Hy. 11.

E. J. Hopkins.

The Temple Chureh Choral Service, edited by Edward J. Hopkins. Supplement, 1877 .

Composed for this hymn.

Ferrier. Hy. 596.

J. B. DYkes.

Accompanying Tunes to the Hymns for Infant Children, 1862.

Composed for this hymn.

Fiat Lux. Hy. 429.

J. B. DYKES.

Hymns Ancient and Modern. Enlarged edition, i875.

Composed for this hymn.

Fidelis. Hy. 590.

A. Sonervell.

The Chureh Hymnary, 1898.

Composed for this hymn.

Fides. Hy. 8.

C. C. Scholefield.

Chureh Hymns with Tunes, 1874 .

Composed for this hymn.

Fiducia. Hy. 45.

S. S. W ESLEY.

Chureh Hymns with Tunes, 1874 .

Composed for this hymn.

Filitz. Hy. 579 .

F. FiLitz.

Vierstimmiges Choralbuch zum Kirehen- und Hausgebrauch

. . . herausgegeben von Dr. Friedrich Filitz, Berlin, [1847].

The melody as here is set to the hymn 'Wem in Leidenstagen.' 
Fingal. Hy, 50.

J. S. Axinerson.

The Scottish Iymnal, i $88_{5}$.

It is there set to the hymn 'I am not worthy, IIoly Lorl,' but was not specially eomposed for that hymm.

Follow Me. 11 y. 567 .

A. Somervell.

The Church IIymnary, i 898 .

Composed for this hymn.

Fortitude. Hy. 561 .

II. R. PALMER.

Sabbath School Songr, i 868.

Composed for this hymn.

Franconia. Hy. 142. I's. 15:2.

Ifarmonischer Lieder-s Shatz, oder Allgemeines Evangelischer Choral-Ijuch. . . gestellet von Johann Jialthasar König, I 738 .

The melody, as under, is set to the hymn ' Mas ist, tas mich betriibt?'
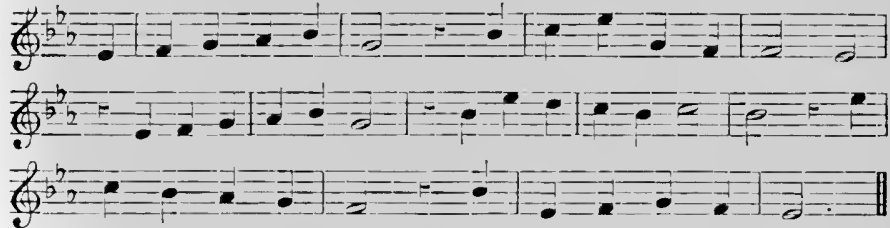

The present tune was arranged from this by the Rev. II. II. IIavergal, and published in his ()h Chureh Psalmoly, is 8 7.

French. Hy. 151, 468. I's. 65.

The CL. I'salmes of llavid, in P'rose and Meeter: with their whole usirall Tunes, ete, Eilinhurgh, I6 5.

One of the 'xii. Common Tunes' foumd in this extition of the Scottish Took of Common Orler. (See under 'Abbey.') The first appearance of the tune in an English l'salter is in Ravenseroft's Whole Booke of Psalmes, I621, where it is named 'I undy,' and clissed in the Index muder 'Scottish Tunes.' 'I umelee' is the name by which it is still generally known in England, though it has also been ealled ' Torwicl.'

Garrett. $\mathrm{II}_{\mathrm{y}} .54$.

G. M. G.hriett.

The Chureh of Engrlinel Ifymmal, 1895.

Composed for the hymn ' $A$ broken heart, my God, my King.' The original name of the tune is 'Walton.' 
Gauntlett. Hy. Appx. 7 .

II. J. Gaunthett.

The Presbyterian Hymnal, 1877.

Set to this liymn (No. 2I I).

Gerontius. Hy. 25.

J. 1). IYKES.

Hymns Ancient and Modern. Appendix, r 868.

Composed for this hymn.

Gethsemane. Hy. 55.

WT. H. Monk (from Tre).

The Actes of the Apostles, translated into Englyshe Metre, and dedicated to the Kynges moste excellent Maiestye, by Christopher Tye, Doctor in Musyke, and one of the Gentyhen of hys graces moste honourable Chappell, wyth notes to eche chapter, to synge and also to play upon the Lute, very necessarye for studentes after theyr studye, to fyle theyr wyttes, and also for all Christians that cannot synge, to reale the good and Godlye storyes of the lyves of Christ hys Apostles, I 553.

The work, of which the above is the full title, contains a metrical version of the first fouteen chapters of the Acts of the Apostles, each chapter having set to it a tune in four parts. The present is adapted from that of chapter xii., which is as follows :

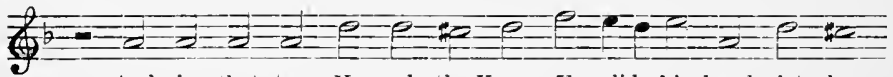

And in that tyme Ifer-orle the Kynge He did his hands let slyp,

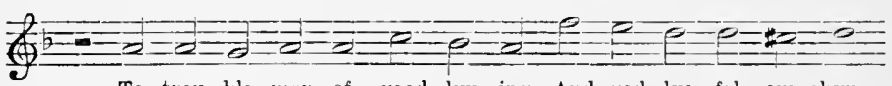

To trou-ble men of good lyv-ing And god-lye fel-ow-shyl,

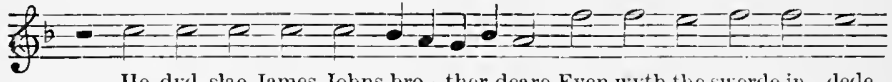

Ile dyd slae James Johns bro - ther deare Even wyth the swerde in - dede,

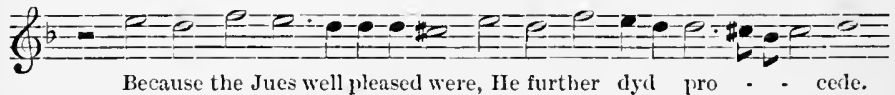

The arrangement by I). W. H. Monk appeared in Hymms Ancient and Molern, I86r, set to the present hymn.

Gibbons. IIy. 479 .

O. Gibions.

The Hymues and Songs of the Church. By George Wither, 1623 .

This work contains a number of tunes in two parts, treble 
and bass, by Orlando Cibbons, the present heing set to the song beginning ' $O$ my Love, how omely now', as follows:-
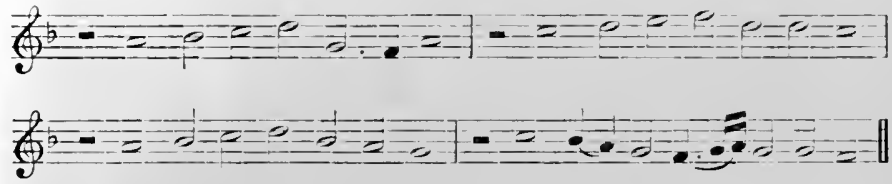

Girtford. 111. 274 .

(i. .I. G. IIIRLTTT.

The Chureh of England IIymual, i 895 .

Composed for this hymn.

Glasbury. 11y, 547.

S. S. Westry.

A Selection of P'salms and Iymms arranged for the I'ulblic Services of the Church of Eingland, eclited by the Rer. Charles Kemble ant s. S. Wesley, i 864 .

Set to the hymm "The Lord is our refuge, the Lord is our guiile.'

Glasgow. l's. 66.

The Psalm singer's Pocket Companion, containing great variety of the best linglish l'sahn Tmes. : . likewise all the Tunes that are nsually sung in mest parts of seutland. Glasgow, 1756 .

One of the collections exlited by Thoma. Moure.

Glebefield. IIY: 200.

J. 1. IYKKe.

13 ymns Aneient and Morlern. Finlared edition, i 875 .

Composed for the hymn 'Joy, becante the circling year.'

Gloaming. $11 y .360$.

J. S'TANLi:

The Chureh Hymnary, isgs.

Composel for this hymn.

Glory. IIy, 333.

C. J. Vixcest.

The Ilymual Companion to the liook of Commen l'rayer, with aceompanying Tunes. Second edition, is $S_{77}$.

Composed for the lymn 'The sands of time are sinking.' The last line of the tune was slightly altered ly the composer to suit the present hymn. 
Glory. Hy. 587.

The Tune Book to the Hymns and Chaunts for Sunday Schools, edited by John Curwen, [1842].

Set to the present hymn, with which it has always been associated.

\section{Gloucester. Ps. 67.}

The Whole Booke of Psalmes. . . . composed into 4 parts by sundry Authors. ... Newly corrected and enlarged by Tho. Ravenscroft, 162 I.

Set to Psalms Io, 48 , and 143 .

Line 3 in the original is as follows :-

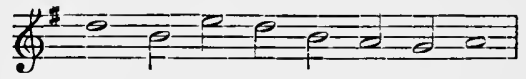

The present form is found in Playford's Psalms, 1677 .

God in Nature. Hy. 521.

J. Stainer.

The Westminster Abbey Hymn Book, I 897.

Composed for this hymn.

Godesberg. Hy. 131.

H. $\Lambda$ LBert.

Finfter Theil der Arien oder Melodeyen. . . . von Heinrich Alberten. Königsberg, 1642 .

Set to the hymu 'Gott des Himmels und der Erden.' Melody exactly as in present tune.

Golden Sheaves. Hy. 495.

A. S. Sullivan.

Church Hymns with Tunes, 1874 .

Composed for this hymn.

Gorton. Hy. 338.

W. Holling WORTH.

IIollingworth's Psalmody, 1889 .

Composed in 1883 for the hymn 'Come, ye that love the Lord.'

Goshen. Hy. 565.

The Bible Class Mragazine, 1860.

The present hymn and tune appear in the above under the heating 'Our Shepherl.' No composer's name or source is given, and the tune has not been found in any earlier publication. 
Gotha. $11 y .619$.

II.R.II. J'Rnise Aluzert.

Songs and Ballads written and set to Music by their Royal Ifighnesses Albert and Ernest, Princes of Saxe-Cobnrg Crotha, 1840 .

Set to a poem by Eichendorff hegrinning 'O wunderhares tiefes Schwingen,' the English transhation being ly G. F. Richardson.

The meloly is as follows:--
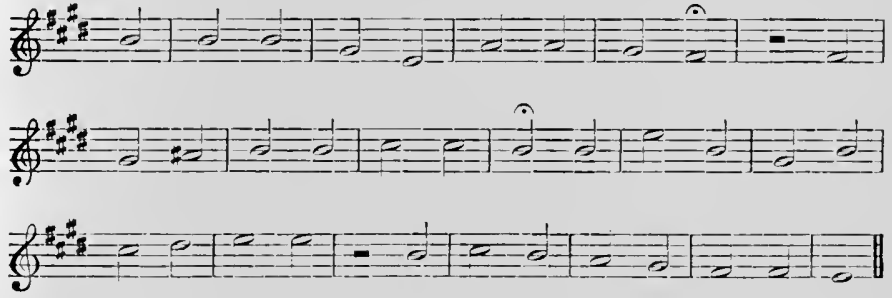

It appeared at a long metre tune in Westrop's T'niversal Psalmodist, and in The Sacred Choir, Glasgow, $18+1$. In its present form $(87.87)$ it is fouml in Lowell Mason's Psaltery, I $8+7$, and in Congregational Church Music, 1853 . Its insertion in this form in the list-named work was expressly sanetioned by the compriser.

Gouda. Hy. 387.

B. Totrs.

The Ilymnary, i 872 .

Set to the hymms 'O Gorl, who lovest to abide,' and 'How sweet the name of Jesus sonnds.' It is not certain for which of these the tune was composed.

Gounod. $11 y .131$.

C. Gouxod.

The Iymnary, 1872.

Set to four diflerent hymns, but composed for 'IIark, ten thousand harps and roices,' which was not ineluded in the collection.

Gräfenberg. $11 y .424$. I's. 6s.

Praxis Pietatis Melica. I)as ist: Ulung ler Gottseligkeit in Christlichen und trostreichen Gesingen... verfertiget ron Johann Criigern. . . E Editio v., lierlin, I653. 
'The melory, as under, is set to the hymu ' Nun danket all und hringet Ehr.'

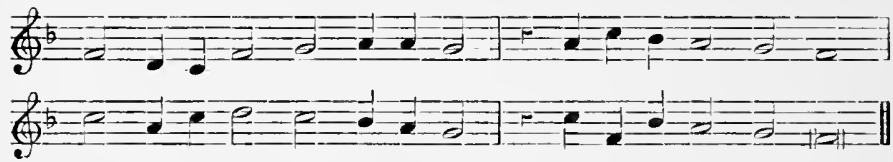

Aceorling to Zahn, the melody is Cruiger's composition.

Grandpont. Hy. 245.

J. Stainer.

The Chureh Hymnary, I 898 .

Composed for this hymn.

Grange. $\mathrm{H}_{y} .375$.

J. М. Bell.

The National Book of Hymn Tunes, ete., I $88_{5}$.

Gratias Agimus. $\mathrm{Hy} .420$.

IV. AllCOCK.

The Church IIymnary, I 898 .

Composed for this hymn.

Gretton. Hy. 224.

R. Jirown-Bontinwek.

The Supplemental Hymn and Tune Book, compiled by the Rev. R. Brown[-Borthwick], i 867.

Set to the hymn 'Thro' all the changing seenes of life.'

Guild. Hy. 259.

A. L. PEACE.

Composed for this hymm, and first printed in r 889 on a single sheet for use at Guild meetings. In its original form the tume is set in Key $\mathrm{F}$ for male voices in three parts, first and second tenor and bass; it was afterwaris arranger by the composer for mixed voices in its present form, and published in Life and Work for January I 890 .

Haddo. Hy. Аppx. 3.

F. J. Норкаль.

The Temple Chureh Choral Service Book, edited by Edwarl J. Hopkins, r 880.

Composel for the hymm ' No, not lespairingly.' Althougl the tune appeared first in the above collection, it was written for the Free Church Hymn Iook pmblisher in is 88.

Hallelujah. IIy, 26.

E. J. Horkess.

The Temple Chureh Choral Service, edited ly Edwari J. Hopkins. Supplement, r877.

Composed for this hymm, and originally named 'Jehovah.' 
Hamerton. IIy. 532.

S. C. H. Hention.

Two Christmas Carols, [1861].

The present is the seeoml of these, and is hoalder] "Waknen, Christian ehildren, worls and molorly hy tho liev.. '. '. Hamerton.'

Hampden. IIY. 5:59.

II. Filistonk.

'The Children's Mymn lionk, adited by Mrs. Ciarey lirock, ı88ı.

Composed for the hymn 'Jexus, we are far away.'

Hampton. Ily. 430. I's. 153.

Psalmody in Miniature, by Aaron Williams, [rira 177o].

It is also containel in 'A Collection of l'salun Tumes in Three Parts. . . . ly ls. Sunith,' which alpealued about the same dite. In this collection the melorly is as follows:-

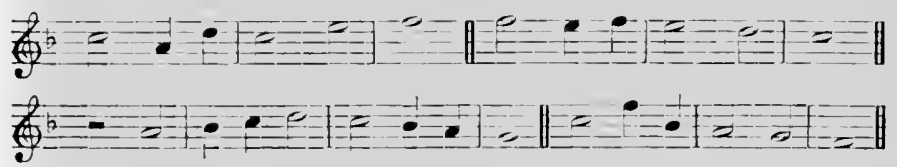

In both of these looks the tune is named 'I 'murhan.'

Hanover. Hy. 12, 19.

II. Clzof's.

A Simplement to the Vew Version of Psalms by Ir. Liarly and Mr. Tate, ete. The Sixth edition, corrected and much enlargerl, 1708 .

The tune is set to the version of P'salm 67 beginning '( ) 17 r Gonl bless us all with merey and love.' It is withont a name, and is hearled '. I New Tune to the r foth P'silm of the New Version, and the rofth P'silm of the ()hl.' No eomposers' names are given. It is genemally believel that Ir. Croft was concemed in the proluction of the above book, hint the evidence in support of his being the composer of the present tume is not entirely conelusive. In collections issued in the end of the eighteenth and begiming of the nincteenth centuries it is frequently attributed to llandel ; but as IIandel did not come to England till I 7 Io, it is almost impossible that a hymn tune ly him should have been published in an linglish eollection in 1708 . Further, the tune is found in many collections published during Inandel's 
residence in England, and in none of them is he mentioned as composer; while in Rilcy's Parochial Music Corrected, published in 1762, within three years of Handel's deatl, the tune is headed 'Hanover tune, the author not known.' In the collection of tunes called the People's Music Book, edited by J. Turle and E. Taylor in 1844 , the tume is called Old royth, and has Handel's name attached to it; but in the Inclex it is credited to Dr. Croft, and the following note added:- "This Tune has been ascertained to be the composition of Dr. Croft, by satisfactory evidence, since the page in which it is contained was printed.'

\section{Happy Land. Hy. 592.}

The source of this melody, which has been described as an 'Indian Air,' has not been traced. The history of its connection with this hymn is thus told by Mr. Andrew Young, the author of the latter, in the preface to a volume of poems published in 1876 :- Many years ago I was spending an evening with a family of friends, and the lady of the house played several musical compositions of great beauty. Among these was a sweet and tender air which charmed me exceedingly. On asking the name of it, I was told it was "an Indian Air called "Happy Land." " It immediately occurred to me that such a melody could not fail to be popular in Sunday schools, if wedded to appropriate words. And accordingly I wrote the little hymn which has now spread over all the world, and been translated into almost all languages. It was sung daily in my classes in the Niddry Street School; and on a visit by Mr. James Gall he was so delighted with the music and hymn, that he noted down the simple air, had it harmonised, set to the words, and published in his Sacred Songs; and from his father's well-known printing and publishing house it was copied into hymn books everywhere, and so became a general favourite.' The full title of the book thus referred to is 'Anthems and Sacred Songs, arranged for Two, Three, or Four Voices, by Alexander Hume.' It bears no date, but must have been issued about 1839 . The hymn and tune are included in Sacred Melodies for Chilılren, edited by C. H, Bateman, I 843 ; 
and in the Juvenile Harmonist, published in the same year hy the Sunday Selool Union.

Harington. P's. 69.?

II. Halisgion.

Retirement: A (ilee for 3 Voices, by IIenry Ilarington, [rirca i 780$]$.

The original form is as folluws :-
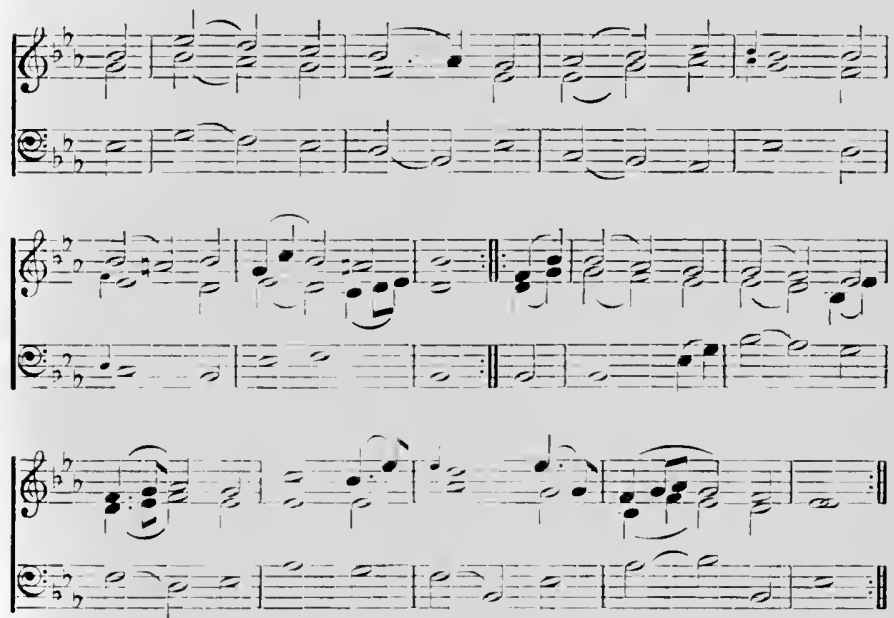

The glee has three verses, the first being -

Beneath the silent ruril cell

Of innocence and peace,

With sage retirement let me dwell

And tiste each hone-felt bliss.

Harrow. IIy. 3:3.

F. F⿻上丨a.

The Chur'h Ilymmary, 1898 .

Compuserl for this hymn.

Harts. IIy. 17 .

I). Mifgrove.

Sixteen Hymms as they are Sung at the Right Honourable the Countess of Ifuntingdon's Chalpel in liath. Siet to Musie by benj" Milgrove, $[1769$ ?].

The present is No. 15 in this collection, and is set as under 
to the hymn 'Brethren, let us join to bless,' with the aldition of a 'Hallelujah,' which has now been dropped.

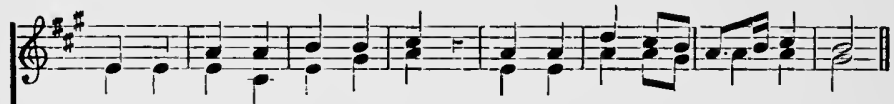

TExor. Sve lower.

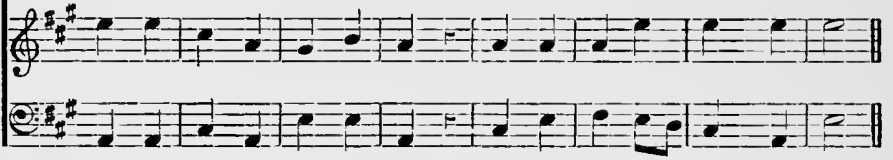

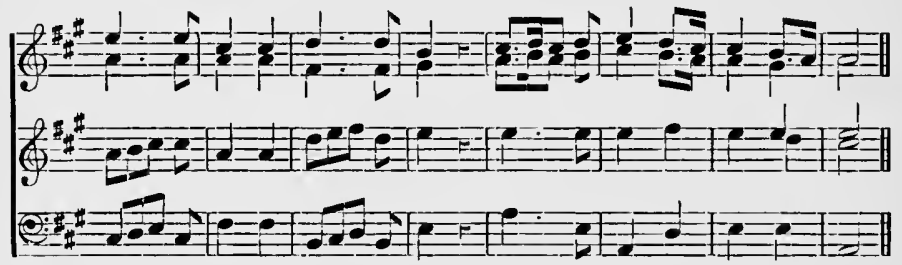

Women alone. AItogether. Women alone. Altogether.
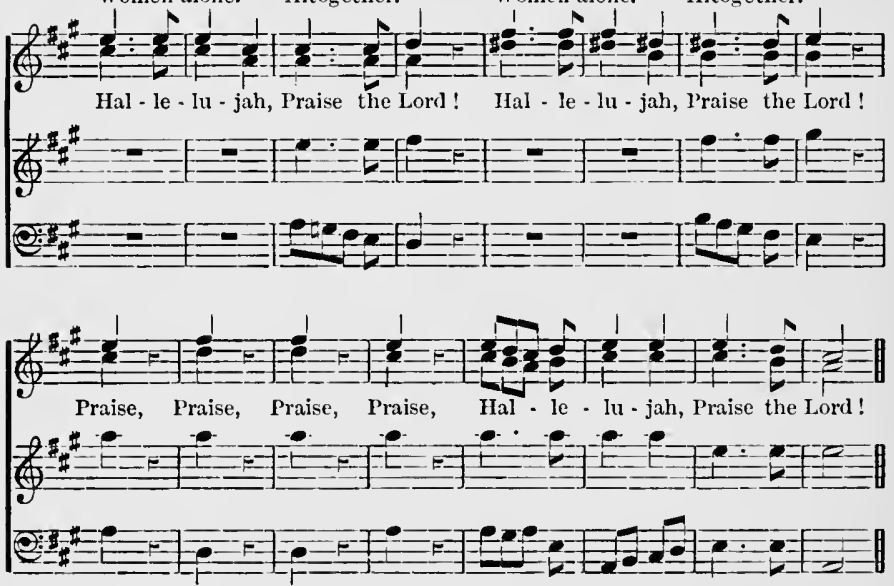

A note at the beginning of the book says, "The Men that sing the Air must rest where 'tis written the Women to sing this part alone, and begin where the word Altogether is written.' 
Harvest. IIy. $48 \overline{7}$.

1). 'Tours.

The Children's Iymn Ibook, edited by Mrs. Carey Brock, i 89 I. Composed for this hymn.

Hasboro. IIy. 492.

1. Ml. Maxis.

The Chureh Jymnary, 1898.

Composed for this hymu.

Havergal. IIy, 412.

IV. H. HAVERGAL.

Havergal's Psalmody, 1871 .

Composed on April 16, 1870 , at the request of a friemd, for the hymm 'Mighty Father! Blessed Son!'

The origrinal has nine lines, the present tume eonsisting of the first three of theee. Mr. Havergal died on 1 pril 19, i 870 , this tune being the last music composed hy him. In llawrol's l'salmody, the memorial volume adited by the emuposer's dinghter, the tume is givon in the three-line form set to the present hymm.

Havilah. $\mathrm{I} y \cdot 62 \pi$.

IV. II. IIAVERGAL.

Havergal's l'salmorly, 1871 .

The Ms. of the tume is diated Januiny isjo.

Hawarden. IIy. 4.).

S. S. WESLEY.

The European Psilmist: I Collection of IIymm Tumes . . . The whole revised. . and much of the new fortion romposed ly simmel Sehastian Wesley, 1lus. I loc., 1872.

Composed for the hymm 'There is a blessed home.'

Heathlands. Hy. $24 \%$.

II. S̈InkT.

Psalms and Hymms for livine 11 or:hip, r 867 .

Set to the hymn ' (iod of merey, (iod of grate.'

Heber. IIy. 441 .

I. MAsON.

The Boston Hamled and Hayhn Sorety Collertion. Nintl elition, 1829 .

Comprosed in $182+$ for this liymm.

Heinlein. IIy. 39.

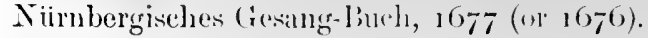

Set to the hymm 'Aus der 'Tirfe rufe irh.'

The melody hats attached to it thr intials .11. II., which Zalu conjectures may stand for Martin Jerbst. The time was attributel in some books to l'aul Heinlein; hence its name. 
Herbert. Hy. 389 .

R. R. CHope.

The Congregational Hymn and Tune Book, edited by the Rev. R. R. Chope, I862.

Composed for the hymn 'My God and Father, while I stray.' In the original the last three bars are as follows:-

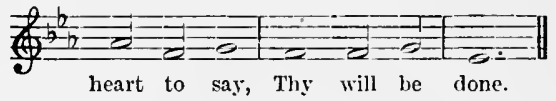

The alteration to the present form was permitted by the composer, on the suggestion of Sir John Stainer, in order to suit the rhythm of the present hymn.

Hereford. Hy. 340.

H. J. Gaunthett. The Church Hymn and Tune Book, by W. J. Bilew and H. J. Gauntlett, $\mathbf{1}_{5} 2$.

Set to the hymu 'Anointed One! Thy work is done.'

Hereford. Ps. 140.

II. HAYES.

Sixteen Psalms selected from the Rev. Mr. Merrick's New Version. Set to Music by W. Hayes, I 774.

Set to the version of Psalm 47, 'Arise, ye people, clap the hand.'

Hermas. Hy. 543.

F. R. Havergat.

Havergal's Psalmody, r87 I.

Set to the hymn 'Earth below is teeming.'

Hermon. $\mathrm{Hy} .46$.

BatTison IIATNES.

The Church IIymnary, i 898 .

Composed for this hymm.

Hesperus. Hy. 41.

II. liAKER.

A Hymmal for use in the English Chmel, with accompanying Tumes, 1866 . Edited by the Hon. and liev. J. Cirey.

Original name of the tume is ' Whitburn.'

Set to the hymn 'Sum of my soul.'

Highgate. Hy. 397.

F. C. Woods.

The Church Hymnary, i898.

Composed for this hymn.

Highnam. Hy. 281.

J. LANGran.

Psalms and IIymns adapted to the Services of the Church of 
Lingland, with aceompanying Tumes, selected and revised by John Foster, r863. (Sce under 'Deerhurst.')

Composed for the hymn 'Gorl that marlest earth and heaven.'

Hilary. Нy, 399.

Zionsharfe, lin Choralschatz . . von 1)r. Comral kinher. Vierte Abtheilung, enthalteml dire schinsten Melenlieen del' Katholischen Kirche, 1855 .

Set to the hymn 'o) du liebe meiner Liebe.'

The name 'Ganther' is attacherl, alprarently as compuner of the tune, but nothing can be discovered about any nuvician of that name.

His for ever. IIy. 215 .

J. BiRNBi:

The Ifymal Comprnion to the book of Common l'rayer. Thirl edition, isgo.

Composed for this hymm.

Hodnet. Hy. I I I x. I3.

DATTAN HATE:

The Church Ilyminty, 1 sogs.

Composed for the hymn 'Then art gone to the grate.'

Holcombe. IIy. 70.

F. H. SYKL:

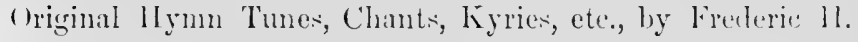
Sykes, [1 8060$]$.

Holley. 11y. 5:0.

(i. Hews.

boston Acerleny Cullection, edited by Lowell Masm, 1835.

set to the hymm "Suftly now the light "f day.'

Hollingside. IIy, 193.

.J. I. 115кK.

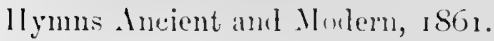

Comprisel for this liymm.

Holy Church. IIy. 194.

1. 11. Binis:

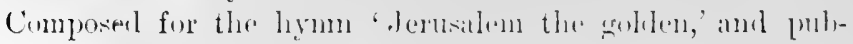
lished in 1862 , along with right others, of which 'st. Anitnlins.' was one, unler' the tithe "The diay is past and orer: an Evening liymn, to which are alled at few wther hymms.'

\section{Holy Cross. 11y. 369.}

1. II. Brow:

The Congregationial Ilinsion Hymual, 1890.

Composed for the hymm 'Show me 'Thyself, o lloly Lord.' 
Holy Trinity. Hy. 104.

J. BARNBY.

New I'salm and Hymn Tunes used at the Church of St. James the Less, Westminster, by J. Barnby, r86r.

Composed for the hymn ' $\Lambda$ s now the sun's declining rays.'

Holyrood. Hy. 576.

J. WATSON.

Psalms and Hymns for Divine Worship, I867.

The tume is anonymous in that work, the composer of the melody being a partner in the firm of J. Nisbet \& Co., the publishers of the book. The harmony is by Dr. Rimbault.

Holywood. Hy. 106, 625 .

This tume seems to have come into use in the Roman Catholic Churches in England about the same period as the 'Adeste Fideles,' but nothing definite has yet been discovered as to its composer or source. It is found in An Essay on the Chureh Plain Chant, I782, in Webbe's Collection of Motetts, etc., I792, and in the Wade MS. at Stonyhurst College. (See under 'Alente Fideles.') In all of these it is set to the Iymn at Benelliction, 'Tantum ergo sacramentum.' The Stonyhurst MS. contains five, and the 'Essay' four settings of the same words in addition to the present. The melody in all the above books is, with very trifling exceptions, the same as in the present version. $\Lambda$ slightly different form appeared in Gardiner's Saered Melodies, vol. ii., I $8 \mathbf{I}_{5}$. It is there headed 'Subject from the Missal Book,' and is set to the hymn 'Lord, dismiss us with Thy blessing.' The same arrangement and adaptation appeared in Sacred Harmony, for St. George's Chureh, Elinburgh, I820; and this form of the tune, under the names 'Disinission' and 'Augustine,' is found in several collections since that date.

Honidon. Hy. 3.

T. R. MaTTHEWS.

Composerl for the hymn 'Jesus, Lover of my soul.'

Printed in a collection of 'Sixteen Tunes' by Mr. Matthews, which was sold in aid of the rebuilding of North Coates Church in 1865 .

Horbury. Hy. 237.

J. D. DYKes.

IJymns Ancient and Modern, 186r.

Composed for this hymn. 
Horeb. $\mathrm{Hy}_{\mathrm{y}} 358$.

J. liskisi.

The Hymnary, i 872 .

Composed for this hymm.

Horsley. Hy. ¿) 40.

W. HORSAEY.

Twenty-four Psalm Tumes and Eight Chants, composed hy Win. Horsley, i $8+4$.

The present tume is So. 3. It has no name, aml is mot reforred to any particular hymm.

Hosanna. $11 y .48$.

J. Liмn:

The Iymmary, 1872.

Composerl for this hymm.

Hosanna we Sing. Ily.5:37.

I. I?. I) IIE:

Hymus Ancient and Murlem. Enlared alition, $1 S_{75}$.

Composerl for this liymu.

Houghton. IIY. 1:2.

II. I. (:.ILXTI.ETT.

The (ongregational I'silnnist, mlitel hy I)r. H. Mllon, Part [] I., I $S 6$ I.

Composed for this lymm.

Houghton-le-Spring. Iy. 2尺i.

S.. WESLEY.

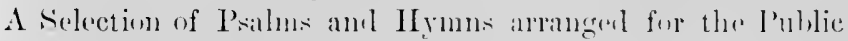
Serviees of the Chureh of lingland, edited hy the liev. Chatres Kemble and s. si. Wesley, is64.

Composed for the hymm 'Rork of Ages.'

The tune is anted a 860 in this work, It is fommel with the. name 'St. Selontian' in . I Irmmal for I'se in the Enerlish

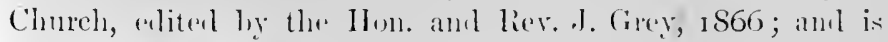
there natred 'Compuned for this work.' The Rev. J. (irey was reetur of IInughtun-le-s]pring.

Howard. 1's. 70.

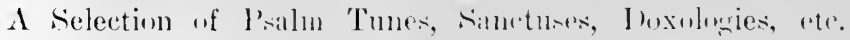

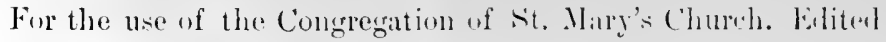
by John Wilson. Eilinburgh, 1825.

The tume is anonymons in this lexk.

In books publisherl in 18 o and in $185+$ it is aseriberl to sir John Stevenson, and in some hroks it has heen eredited 
to Dr. Samuel Howard. The latter statement is entirely without foundation, and is a mistake arising from the name.

Huddersfield. Ps. 71 .

II. MADAN.

A Collection of I'salm and Hymn Tunes, never publisherl before, i 769. Edited by M. Madan.

Known as the 'Lock Collection.'

In the original the second half of the tune is as follows:--

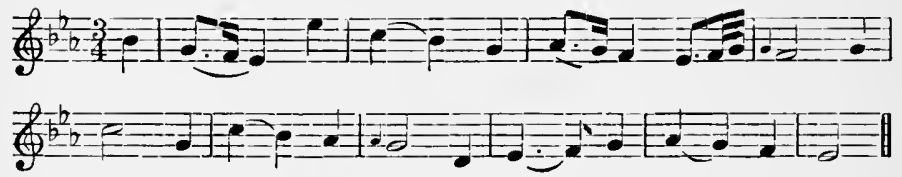

Set to the hymn 'My hiding-place, my refuge, tower, and shield art Thou, O God.'

Hull. Hy. 465.

The origin of this tune is very obscure, and it is quite uncertain whether it was originally the melody of a seeular song or of a hymn tune. In 'The Ameriean Musieal Miscellany: a Collection of the Newest and Most Appoved (sic) Songs, set to Music. Printed at Northampton, Massachusetts, by Andrew Wright, I798,' it appears as under, set to a song ealled 'The Indian Philosopher':-
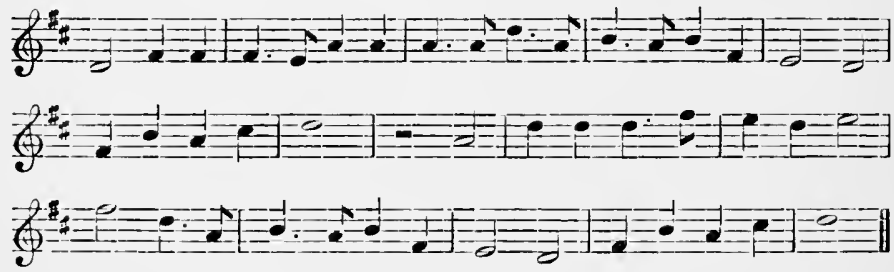

In regard to this, Mr. IIubert P. Nain, of Now York, writes: 'I have seen it in earlier books, but when it was first adapted as a sacred hymn tune I do not know for certain. I think, however, it was used by the early Methorlists as far back as 1770 , and possibly came to America from England with the early Methodist preachers. It was one of the fayourite hymns of the early Methodists and Congregationalists ; generally ealled "Ganges," and credited to S. Chandler, 
I790; but this is evidently an error. Chandler wrote a tune about i 790, or earlier, commeneing as follows:-

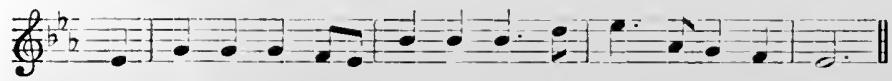

but the only similarity to "Ganges" is in the first line."

In 1731 the Rev. Joshua Leavitt inchuled the tune in The Christian lyre, and stated that it "was originally composed for a song of I r. W'atts'; but he loes not give the oricrinal words, nor the name or date of the publiation in which it first appeared.

Humility. $\quad 11 y, 520$.

1. (ioss.

Christmas Citrols, Sew and Old, edited hy the liev. 11. R. Iiramley and J. Staner. Sceond series, 1870.

Conposerl for this hymm.

Hursley. 11y. 3.5.

Sire 'l'ascall.'

Iconium. P's. $7:$.

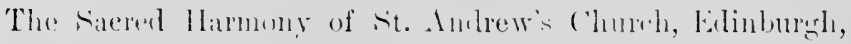
adited hy diam limman, is $S_{+3}$.

The tume is here attributed to 1)r. Nires, hut it has mot heen found in any older collection, and the stitement as to the comprese lasks ronfirmation.

Ilkley. Hy. 117.

J. H. 1)YKEs.

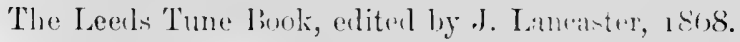

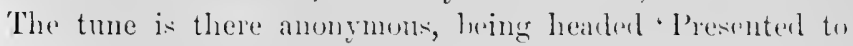
the elitor,' and is set to the hymm "There is a ealu for these who weep.' In the Free Chureh lymu lionk, 1882 , it is set to the present lymm, and is agitin without composer"s name. In an artiele in the strand Magazine for July 1895 , a faresmile

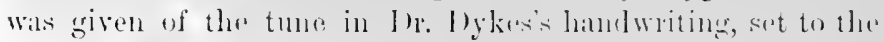

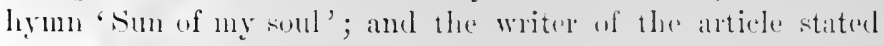
that it was an impuhli-herl tune, and haul luen "griven hy Dr. lykes shortly hefore his death to a frimul, antong whose papers it harl lain for many yeals.' 'The farets alre that the tme was enmposed by 1)r. Dykes for 'Sun of my soul,' and given in Ms. to Mr. Sumowlon, viear of llkley, for the nse of the choir of his church. Dr. lykes never consented to, and was possibly not aware of, its publication in the Leeds Tune 
Book. It may have been given to the editor of that book by a member of the choir or some other friend at Ilkley. The harmony of the tune seems to have been altered more than once by Dr. Dykes. The present is believed to be his latest version.

Illsley. 11y. 117 .

J. Bishor.

A Sett of New Psalm Tunes in Four Parts. . . B By Joln Bishop, organist of the College at Winton, [ $\mathrm{r}$ 7oo].

Set to Psalm Ioo, 'All people that on eirth do dwell.'

In the Scottish Hymnal and Scottish Psalter the tume was altered in the last line. It is now restored to the original.

Illuminatio. Hy. 154.

G. J. Elvey.

The Chenies Tune Book, specially adapted to the Book of Common Praise. Dedicated to the Rev. the Rt. Hon. Lord Wriothesley Russell, Rector of Chenies, with affectionate respect by his Daughter. Ldited by E. G. Cocks. (Preface (lated Dec. I 885.)

This tume is there called 'Cephas,' and is marked 'Composel expressly for this work.' It is not referred to any particular hymn, but was probably written for ' Rock of Ages.'

\section{In Memoriam. Hy. 586. \\ J. Stainer.}

Hymns Ancient and Modern. Enlarged edition, I 875 .

Composed for this hymn.

This tune was written in the following circunstances:-The committee engaged on the music of the above were meeting at the Langham Hotel, London, and when this hymn came up for consideration it was found that though they had several tunes before them, none were considered satisfactory. It was suggested that a new tume might be written by one of the conmittee, anr sir llenry laker proposed that Sir John Stainer should retire to his (Sir IJenry's) bedroom, and try what he conld do. Sir John complierl with the suggestion, and in a very short time returned with the present tune, which was at once adoptet.

In Sabbato. 11y. 602.

IV. H. Moxk.

The Church of England Ilymnal, i 895 .

Though first published in this book, the tune was written 
for the Westminster Abbey IIymn liook, which was in preparation before Dr. Nonk's death, though not issued till 1897 .

The tume was romposed for the hymn '. Is Thom didit rest, (1) Father.'

In the Field. $115,529$. J. PALMER.

Christ and llis Sulliers: 1 Sacred Oratorio, is 878 .

Worts and minic reproduced exactly from this work.

Innocents. IIy. 299.

The P'arish Choir, vol. iii., No. 59, November is5o.

Shet to the hymn 'Little flowers of martyritum' under its present name, and styled as an 'Ineient Iitany.' The melorly has not, however, been traced to any earlier sontre.

Innsbruck. IIy. 416 .

II. Istac:

The melody hat heen arenerally attributed to this composer.

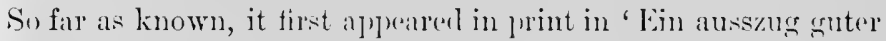
alter un newer Tentscher liedlein. Niirnberg, I539.' It is there set to the songr 'Inshruck ich muss dirh liswon' in the following form :- -
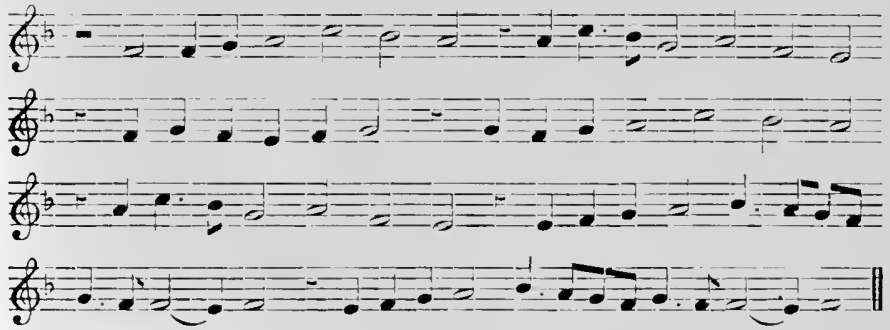

Later the melorly was arlapted to the hymn ' $O$ We't ich muss dich lassen,' and later still to Gerhardt's hymn 'Num ruhen alle Wiiliter."

The melorly appear in a large variety of forms in German collections from the alove date to the present day. The form of the melorly here, with the exerption of the last line, is that adopted by Bach in his 'St. Matthew Passion' and elsewhere. The harmony is also largely lik. The last line has been moditied to suit the metre of the hymn. 
Intercession. Hy. 393.

II. II. Callcott.

Psalms and Hymns for Divine Worship, 1867.

Composed for this hymm.

The last two lines are from Mendelssohn's 'Elijah,' being lart of the prayer for rain by the prophet and people.

Intercession. Ps. 10.

Easy Music for Clumeh Choirs. Part III., I 853.

Set to the hymn 'Deus tuorum militum.'

This work contains music for the various parts of the service of the Roman Catholic Church. No composer's name or source is given for this tune, and it has not been traced to any oliter source. It was included under its present name in the Appendix to Hymms Aneient and Modern, r 868.

Invermay. Hy. 575 .

J. LiMB.

The Presbyterian IIymmal for the Young, i 882.

Composed for this hymn.

Invocation. Ps. 222.

R. A. SyiriI.

Sacred Music . . sung in St. George's Church, Elinburgh, edited by R. A. Smith, r 825 .

Composed for Psilm 43, vers. 3-5, with which it is always associated.

Irby. Hy. 533 .

H. J. GavitietT.

Hymus for Little Chilıren. . . . Set to music with pianoforte accompaniment, by H. J. Gamitlett, 1858 .

Composed for this hymn. As originally written, it was intended to be sung by roices in unison, with harmonised accompaniment.

Irene. Hy. 311.

C. C. Scholefield.

Church Hymns with Tumes, i 874 .

Composed for this hymn.

Irish. Ps. 73.

A Collection of Hymns and Sacred Poems, Dublin, I 749.

The present tume is among the 'Tunes atapted to the foregoing Iymns' at the end of the volume. It is without a name, and seems to have reeeived the name 'Irish' in Ash worth's colleetion, published about 1760 . 
Israel. $\mathrm{Hy} .27,204$. (․ C. Mantis.

The Church Irmnary, r 898.

Composer for No. 20,4, 'Come, O 'Thum Traveller unkmown.'

Jackson. Hy. 620. I's. 74.

T. J J

Twelve Psalm Tunes and Eighteen Tomble and ringle Chants . . . (omposed for Four voices, 1780.

Set to P'raln 47. In Ir. Miller's cullection, issued in 1 SoO, the tume is called 'liyzantimm, and it still bears this nam. in English collections.

Jam Lucis. 11 y. 318.

This meluly is one of sereral set to the hymm 'Jam Jucis orto sidere, in Guilletti's lirectorium Chori, tirst published in I582. It seems to have been adilytel from musi: in use before thit late to some of the short versicles and responses verimring in virious church utrices:

Jesu Magister Bone. Ily. 209.

J. H. I) YTES.

The Sung of I'roise; or, I'salm and Hymn Tunes, enllertal and anranged by Tictoria Evans-Freke, $18-6$.

Composed for the hymn '() Jesus, I have promincel.'

Jesu Refugium Meum. 11y. 193.

Tollständiges Hessen- Hananisehes l'silhnen- und ChoralBnch..... heransgegeben von Johann linniel Miillele Franckfurt an Mayn, 175.

Set to the hymm 'Komm mein Jesu, koum zu mir.' Harmonised by Sir John Stainer for 'The Church Hymmary.

Jesus Loves Me. Ily. 548. IV. H. MiRAnistiy. The Golden Chain, ellited by Wr. 1). Brarlbury, i 86 i. Composed for this hymn.

Joy Bells. Hy. 612. J. STHINER.

The Chureh Hymnary, i 898 .

Composed for this hymu.

Joyful. $\mathrm{H}_{\mathrm{y} .} 589$.

T. Haby.

The Tume book to the Hymns and Chamts for Sumlay Schools, edited by John Curwen, [18+2].

Set to the present hymn. 
It also appeared in The Juvenile Harmonist, published in I 843, where it is ascribed to 'Bilby.' The hymn appeared without music in Bilby's Infant Teacher's Assistant, 3rd elit., 1834. It has been doubted whether he composed the tune, but his son, Mr. Henry Bilby, elaims for his father both hymn and tume. It has been suggested that the tune may be baserl on one which appeared in The Christian Lyre, New York, 1832 , but the latter seems to resemble the present tune only in respect of a few phrases and the rhythm of the refrain.

Jubilate. Hy. 626.

II. Simart.

The Presbyterian Hymnal, 1877 .

Composed for this hymn.

Just as I am. Hy, 175.

J. BARNBY.

The Home and School Hymnal, I892.

Composed for this hymn.

Kemsing. Hy. 496.

J. W. Elliot'.

The Church Hymnary, I 898 .

Composed for this hymn.

Kenilworth. Hy. 130.

E. BuNNeTt.

The Church of England Hymnal, I895.

Composed for the hymn 'A wake, ye saints, awake.'

Kensington. Hy. 60.

W. D. Maclagan.

Hymn Tunes by William Dahrymple Maclagan, D.D., Lord Bishop of Lichfield, r 884 .

Composed for the hymm "Weary of earth, and laclen with my sin,' but afterwards set by the composer to the present hymm, of which he is the author.

Kensington New. Hy. 105.

J. Tilleard.

I'ublished separately in I 866 as an 'Advent Hymn' to the words 'Lo, He comes with elouds deseending.'

Kilmarnock. Ps. 75.

N. Dougall.

Parochial Psalmody: A New Collection of the Most Approved Psalm Tunes .... By J. P. Clarke. Seeond edition, I 83 I.

The above seems to be the earliest eollection in which the 
tune was printed, but it was certainly circulated in manuseript for some time previuusly.

In $185+$ the eomposer issued a volume entitled ' l'wens and Songs by Neil Jougall, with a Memoir of the Author.' 'The' following prassage oceurs in the Memoir:- "One day IR. 1 . Snith and the late Joln Taylor, who was then Preeentor in the Mirdle Parish Chureh, paid him (1)ougall) a visit. . . . After some converwation Smith sairl, "Anything new doing, Mr. Dougall ? nu seraps to divert ths?" Mr. Inugall went to a clawer and brought the first few seraps of paper he endel lay his hand on. Simith took up one, and hastily humming it over, saill, "A very pretty melorly ; and what do you call it?" "It's not ehristened yet," was the answer; "but do you olserve anything peruliar about it?" "I \&lo," sairl Sunth; "it is on the Calerlonian scale, the same as "Morven." "Yes; the sume as your tune." "No, no; not my tune," sais smith. "Wrill you oblige me with a coly of your nameless tume?" "With pleasure," said the composer, "and we'l christen't 'Kilmarnock';" and this ented the conference.'

Kilsyth. 1's. 76 .

The melorly from which this is adapteal is found in 'Coeystliehe Lierler', leipzig, 1 $5+5$.'

It is set to the hymm 'Allein zu dir Ilerr Jesu Christ,' amel comsists of seven lines. 'The material of the first three lines of the present tune is tracealble in the original, but there is nothing corresponting to line 4 .

Knecht. IIy. 293.

.J. 11. KXECHT.

Vollstimlige Sammlung . . . Chomalmelorien . . . Herausgegeben von Christmamn und Kuecht, Stuttgart, 1799.

The present tune is exactly as in the alwre collection, where it is markel as new, and is set to the hymn 'Der niedern Menschheit IIiille.'

Lacrymæ. Hy. 388. A. S. Sillivas.

The Hymnary, i 872.

Composed for the hymn 'Lord, in this Thy merey's ilay.' 
Lambourne. 11y. 255.

G. C. Martis.

The Church Hymnary, 1898 .

Composed for the hymu 'Jesus, Thon joy of loving hearts.'

Lancashire. Hy. 83 .

II. Sitan'T.

Psalms and Hymms for Divine Worship, i 867 .

Composed about i 836 for the hymn 'From Greenland's icy mountains,' on the occasion of a missionary meeting at Iblackburn.

The musie of the opening 'Alleluia' of the present hymn was adled by Sir John Stainer.

Lancaster. Ps. 77 .

S. HOward.

Paroclial Harmony; consisting of a Collection of Psalm Tunes in three and four parts, ete, by William Riley, r 762.

Set to Psalm I, and called 'St. Clement's 'Tune.'

Laudes Domini. Hy. 122.

J. Barnby.

Hymns Ancient and Modern. Appendix, 1868.

Composed for this hymn.

In his 'Original Tunes' published in 1869, the composer altered the last two bars as follows:--

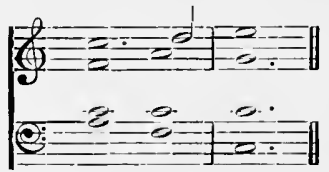

This alteration, however, has not been alopted in other collections.

Laus Deo. Hy. 23.

R. Redinead.

Churel 1Iynum Tunes, ancient and modern, for the several seasons of the Christian Year,... selected, composed, and edited by Richard Redhead, 1853 .

No. 46 in that collection. The above name was given to the tune in The Church 1 Jymnary.

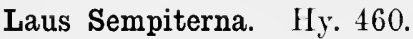

E. Provit.

The Congregational Church Hymnal, i887.

Composed for this hymu. 
Lawes. $11 y .206$.

II. I.IWEs.

A Paraphrase npon the l livine Poems, hy Georese Sandys, 1638.

This, the secomel edition of Simlys's metrical version of the Psalms, continin a mumber of tmes ly lienry Lawes, in two parts, Treble and bass. The present is the tume sot to P'silm 32, harmonised hy Sir John Stainer for The Cliurel Hymnary. The tumes are anonymons in the ${ }_{1} 6_{3} 8$ enlition, but those of later date give IJenry Lawes as the eompuser.

Lebbæus. Hy. 559 .

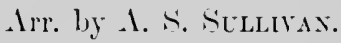

Church IIymms with Tunes, 1874 .

Siet to two metrical litanies.

The tune is andmynous in the alove book, but is marked in the lnctex as arranged by the ellitor, Sir 1 . Sullivan. The actual souree of the melorly is unlinown. It alyerared with a different seeond line in Children is Worship, 1879 , edited hy br. Henry Allon.

Leicester. Hy. 411.

WT. Innist.

Hymns Ancient and Modern. Enlarged elition, 1875.

Composed for this liymm.

Leipsic. Hy. 148 .

C. (iREGUR.

Chomalluch, enthaltenil alle zu dem Gesunghuche dor Lvangeliwehen brüder-Gemeinen vom Jahre 1778 gehörige Dlelorien. I.eip)ig, 1784 .

This eollection was elited hy Cloristian (iregor.

The present melorty, which is set to the liymu "Der Targ vertreibt die finstre Nacht,' is marked as new, and there is little doubt that it was composed by Gregor himself.

The harmony is by Sir Joln Stainer.

Leominster. $11 y$. 305.

(i. W. MARTIN.

The Joumal of P'art Muric, vol. ii., I 862.

Comprosed for this hymu.

The present arrangement is hy sir 1 . Sullivan, and appeared in Church Hymms with Tunes, I $87+$, where, however, the tume is not acknowledged to Martin, but is stated to be an old melody.

Leoni. $\mathrm{Hy} .302$.

The history of the connection of this hymn and tune alpears 
to be as follows:-The hymn by $\mathrm{T}$. Olivers was written about I77o, and is founded upon the Hebrew Yigrlal, or Metrical Doxolugy sung at the close of the synagogue service on the eve of the Sabbath. Leoni was then ehorister at the Great Synagogue, Aldgate, London. Olivers applied to him for the melody to which he was in the habit of singing the Yigdal, and published the hymn in tract form, with the following title:'A Hymn to the God of Abraham. In Three Parts : adapted to a celebrated air sung by the priest Signior Leoni, at the Jews Synagogue in London.'

The form of the meloly in The Church Hymnary, so far as it differs from that hitherto in use, is in accordance with that found in ' $\Lambda$ Handbook of Synagogue Music for Congregational Singing, r889, edited by the Rev. F. L. Cohen.' Mr. Cohen states that this is 'the most correct form of the melody at present in use.'

Leuchars. Ps. 169.

T. L. Hately.

Scottish Psalmody, i 858.

Composed for Psalm I 43, second version.

The tune has appeared with slight ehanges as regards the length of the first and last notes of each line. The present is the form in which it was written by the composer.

Lichfield. Iy. 431.

IV. I). Maclagan.

Iymns for Mission Services, by the Compilers of Mymus Ancient and Modern, with accompanying 'Tunes, 1877 .

Set to the hymn 'My God, and wilt 'Thou hear my ery?'

Original name, 'Spes poenitentis.'

Limpsfield. Hy. 609.

J. Воотн.

The Church Hymnary, 1898.

Composed for this hymn.

Lincluden. Hy. Аppx. 6.

W. H. MONK.

The Congregational Church IIymnal, I 887.

Set to the hymm ' Walking with Thee, my God.'

Litany. Hy. 262.

IV. Newront.

Chureh Hymnal (authorised by the Irish Episcopal Church), I 874 .

Composed for this hymn. 
Little Children. Hy. 530.

(i. J. Hatey.

Christmas Carols, new and old, elliter by the Rev. If. IR. Bramley and Sir John Stainer. First series, 1867.

Composed for the carul 'Come, ye lofty, eome, ye lowly.'

Liverpool. I's. 78 .

R. WAINWRTHT.

Ilivine ITamony; being a Collection in Seore of P'salms and Anthems, composed by the most eminent master.s. . . . Selecterl ant . . Revised by R. Langton, 1774 .

Set to Psalm 8, without a name. The present name is given in ILarrison's siacred Ilarmony, wol. ii., 1791.

Some variations aceur in the melorly ats given in cliflerent. books. The present is in aceordance with the original, exeept that one on' two grecere notes are omitterl.

Lochbie. $11 y .550$.

IV. H. Mlowk.

The Congregational l'silmist Iymmal, edited ly lr. Henry Allon, 1886.

Composed for this hymn.

London New. 11y, 25:2, 507. P's. 79.

The P'salnes of 1havil in P'rose and Ifeeter, with their whule T'unes, etc., Eilinburigh, 1635 .

()ne of the thirty-one 'C'ommon Tunes' found in this edition of the Seottish book of ('ommon (Order. (See unter 'Caithness.') The tume is there namel ' Newtom,' and the melorly is the same' as the present, with the exception of line 3 , which reats thus-

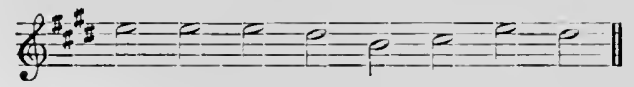

This form is found in the collections of Hruce (1726), liremner $\left(175^{6}\right)$, and many other Seottish books, lown to alout I820; principally in the bouks issued in the ectst and north of Seotland. The present form of the melonly seems to have appeared first in l'layford's l'salms, 1671 , and is that founl in all English broks, and also in Moore $(1-62)$, Mlolten ( $7-66)$, and other books publisherl in the rest of scothanl. It is the form foumt in R. A. Smith's Collection, 1825, and since that date has become universial. Another variation in the meloly is the substitution at the fourth note of line 2 of the sixth or 
fourth of the scale instead of the fifth. This peculiarity is found in the Supplement to the New Version of the Psalms, I 708 ; in some editions of Playford ; in Chalmers's Collection, Aberdeen, 1748 or 1749 ; and in one or two other books published in the north of Scotland.

Longwood. 1Iy, 298.

J. Barnbi.

The Ilymmary, i872.

Composed for the hymn 'Saviour, again to Thy dear name we raise.'

Lowliness. Пy. 541.

13. R. Hanby.

The Dove: A Collection of Mrusic for Day, and Suntay Schools, Chicago, I 866.

Composed for this hymn, of which the composer is also the author.

Lowton. Hy. 390.

A. LowE.

The Hymnary, 1872 .

Composed for the hymn 'Spouse of Christ, in arms contending.'

Lübeck. Hy. 192.

Geistreiches Gesang-Buch . . von Johann Anastasio Freylinghausen, Halle, I 704 .

Set to the hymn 'Gott sei Dank in aller Welt,' as follows :-

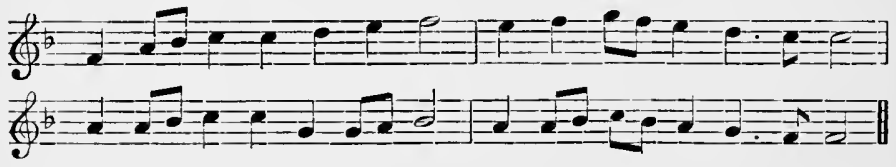

Lucca. Hy. 316.

The origin of this tune seems to be a secular song found in a collection issued by Jacobus Regnart at Nïmberg in $\mathbf{1 5 7 4}$. The melorly is as follows:-

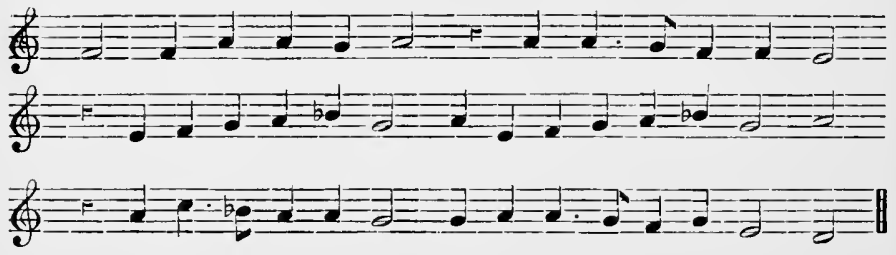


It was tirst set als a hymn tme to the words "Man sprielet: Wen Gott erfrent,' by birtholomew (xesins, in his fin amler new Opus (reistlicher l heutscher Liedrer, publishral at Frankforton-Orler in I605.

The melorly there is considerably altered from the alove, and further variations oecur in sulkefuent ferman bosks. In Sehein's Cantional, 1627, it appear's as muler, set to the hymm 'Auf meinen lieben (iott,' and this form his ben gemerally atlopted in later books.

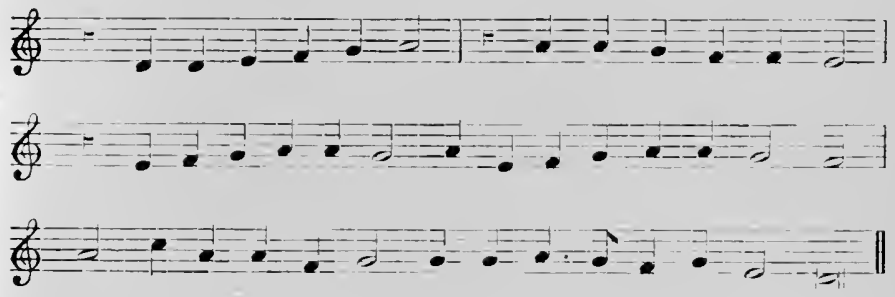

Ludborough. II. .5)

T. R. MATTHEWS.

Church llymus with Thues, 1874 .

The tume was composel in 18 fo for the lymu 'Fom arery stormy winl that bluws,' hut remainest in Ms. till [mblisherl in ('hureh llymus.

Lugano. 11 ș. 363.

Catholir Ilymn Tumes and litamies, anlapted to Latin and Euglish words, edited hy J. M. ('apes, list., $18+9$.

Set to a Kylie, aml healed 'I itany li. V...1.'

Xo information is grven ats to the sondee of the melexly. The present arrangement and alaptation to this hymm was male ly Willim Shore, and appeared in The Musinal Times for ouly 1850 .

Lumen Vitæ. II . 300.

J. Hisкв:.

The Sirum Ilymual, with proper Tunes, the Music erliterl hy T. E. Aylward, i 869 .

Composel for the hymn 'Learl, kimlly Light.'

The name of the tune, as above, appeatrs first in The Clourch Ifmnary ; in some other collections it is called ' (rriel.' 
Lux Alma. IIy. 345. Ps. 11.

II. J. GaunthetT.

The Office of Praise, 1870. Edited by Dr. Crauntlett.

The tune was probably first printed in this book, though it is not among the tunes marked in the Index as 'Composed for this work.'

Lux Benigna. Hy. 297.

J. B. DYKes.

Psalms and Hymns for the Church, School, and Home, elited by the Rev. D. T. Barry, 13.A. With accompanying Tunes from the Parish Tume Book, 1867.

Composed for this hymn.

In the above book the tume is named 'St. Oswalı.' It is set in the key of $G$, and contains slight differences in the harmony as compared with the present arrangement, which appeared in Hymns Ancient and Modern, Appendix, 1868. It was doubtless revised by the composer for that work.

In the Life of the composer it is stated that 'Dr. Dykes's friends remember his telling them that the tune to "Lead, kindly Light" came into his head while walking through the Strand in London.' The Rev. George Huntington relates the following incident: 'I had been paying Cardinal Newman a visit. . . . I happened to mention his well-known hymn "Lead, kindly Light". . I ventured to say, "It must be a great pleasure to you to know that you have written a hymn treasured wherever English-speaking Christians are to be found; and where are they not to be found?" He was silent for some moments, and then said with emotion, "Yes, deeply thankful, and more than thankful"; then, after another pause, "But you see it is not the hymm, but the tume, that has gained the popularity! The tune is Dykes's, and Dr. I)ykes was a great master."

Lux Eoi. IIy. 82, 469, 628.

A. S. Sullivan.

Church IIymns with Tunes, I $S_{74}$.

Composed for the hymn 'ILark ! a thrilling voice is sounding.' The tume was written for the second edition of Hymns for the Chureh of England with proper Tunes, but that book not having been publishert till 1875 , the actual first appearance in print of the tume was in Church Hymus. 
Lux in Tenebris. $11 y . \Lambda_{p} p x .11$.

A. S. Sirlukis.

Six Sacred Part-Sings, by $A$. A. Sullivan, 187 I.

Composed for this hymn.

Lux Mundi. Hy. 161.

1. S. Sildivax.

The IIymary, r 872.

Composinl for this hymm.

Lux Prima. $11 y .347$.

G. A. Marearimes.

The Songr of l'raise; or, I'salm and Ilymu Tunes, collected and arranged by Victuria Evans-liekw, a 876 .

Composed for this liymm.

Lyndhurst. ॥y. 599.

Church I'raise with Tines, 1883 .

The tune was given to the committee who compiled the alwo book hy Mr. Alexander Guthrie, after whose resilence in Liverpool it is numed. Mr. Cuthrie states that the laughter of the Russian Consul in liverpol having "heard the air somewhere on the Continent, noted it lown, and had it harmonised by a musieal friend.' When it came into Mr. Ciuthrie's hands, it was set to the present hymm.

Lyte. $11 y .301$.

J. WHKEs.

IIyms Ancient and Modern, I 861.

Composer for this hymu.

Madrid. $\mathrm{H}_{y}, 5+4$.

The origin of this tune is obsure. So far as las been ascertaineel, its earliest appearance as a hymn tune was in a publication unler the following title, "The Spanish Iymm, arranged amb composel for the Concerts of the Musical Fund society of Philatelphia, by Benjamin Carr. The dir from an ancient Spanish Melody. I'rinter from the comlensed seore of the Society, and presented to the Composer as a tribute of respect and regard by some of the members, his friends. Ihiladelphia, 1826.' The preface to the publication states that the music was performed on December 29, 1824 .

Under the name 'Spanish Chant,' the tune appears in A Collection of Metrical Versions, ete., by M. Burgoyne, London, iS27. 
Magdeburg. Нy. 502.

F. Fuxcke.

Lüneburgisehes Gesangbueh. . . L Liineburg, I686.

Set to the hymn 'Jesu, meines Herzens Freud,' as follows:-
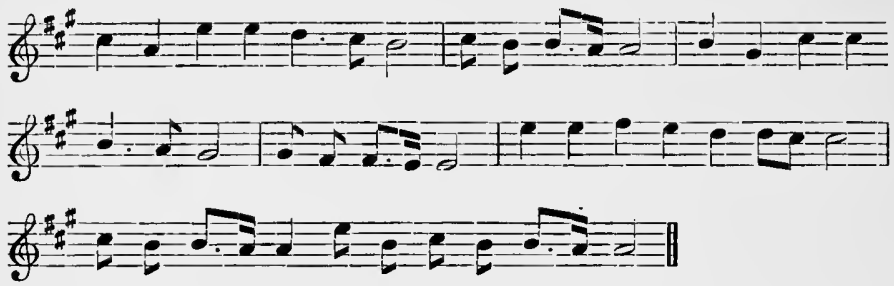

The present adaptation appeared in The Home Hymn Book, 1886, and is by Mr. Edwin Moss, the musieal editor of that work.

Maidstone. Hy. 377.

W. J. Gilibert.

Songs of Praise and Ten other Hymns set to Musie by Walter B. Gilbert, [1862].

Composed for the hymn 'Songs of praise the angels sang.'

Mainzer. Hy. 140, 437, 448. P's. 12.

J. Mainzer.

Mainzer's Choruses, No. 2, [circa 1841$]$.

Set to a version of Psalm 107 .

In the composer's Standard P'salmody of Scotland, 1845 , it is set to the second version of Isalm 102 .

Mamre. Hy. 568.

F. K. L. Scilolinus.

Hauschoralbuch. Giitersloh, 1844.

Set to the hymn 'Erwacht vom siissen Selılummer.'

Manchester. P's. 80.

R. WAINWRIGITT.

Divine Harmony ; being a Collection in Score of Psalms and Anthems eomposed by the most eminent masters. . . . Selected and . . . Revised by R. Langdon, 1774 .

Set to I'salm IO3, without a name. The present name is given in Harrison's Saered Harmony, vol. i., i 784 .

Mannheim. Hy. 295.

F. FiLit\%.

Vierstimmiges Choralbueh zum Kirehen- und IFausgebrauch ... herausgregeben von Dr. Friedrich Filitz, Ijerlin, [1847].

The present form of the melody appeared in Congregational 
Church YLusie, 1853 , and is much altered from the original, whieh is as unler, and is set to the hymm 'Auf, auf, weil der' 'Tiug erschicuen.'
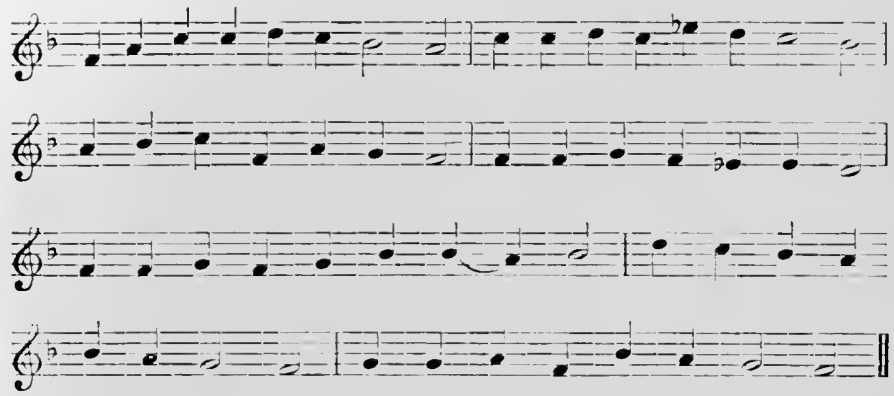

Mansfield. $11 y, 7: 3$.

I. linkwisi.

The Cungregational Missim Ilymual, isgo.

Cimpresed for the hymin 'Ye of the Father loverl.'

The tune wis set to the present hymm, with the eompuser's approvil, in the llome and seluol IIymull, i 892.

Mariners. Hy. .心I.

This meludy is salul to be a sicilian but-sing. The ariginal latin worts are a hronn alderseel to the Virgin, herinning

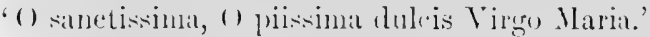

In the entitinn of J. (i. llemler's anllected works, Thibingent, I 807 , part $S$ of the section entitled '\%ur schönen literatur und limst, a fiernan translation of the aluse is given with the present meluly. It is heared 'An die Jungfral Maria. Gïn sieilianiseher schifferlied,' with the following note: 'Als shrinste I'robe italianiwher Vullislieder steht hier, statt vielor, das sirilinischer sehifterlied mit seinco einfachen sinften Mclodie in Original und in einer hiezu singbaren Uebersetzung.' to far as hats been discuvereml, its earliest appraranee in an linglish collection is in 'The P'sillus of litvil from a Puetical Version, ly" the Rer. James Meriek . . with new music collerterl from the most eminent composers, hy the liev. W. 1). Tattersill, I794.' It is there set to the tirst seven veriess of Psilm 19, and is styled 'sicilian Iymu.' 
Marken. Hy. 349, 404.

1). Touns.

The Iymmary, 1872 .

Set to the hymns 'The flaming sun has sunk in night' and ' $O$ happy day when first was poured.' It is uneertain for which of these the tune was composed.

Marlborough. Hy. 250.

Arr. by 1 . S. Selliwan.

Church Ifymns with Tunes, I 874 .

Set to the hymn ' $O$ Strength and Stay, upholding all ereation.'

Martyrdom. Hy. 236. Ps. 81.

H. WILSON.

Composed in the end of the eighteenth century and first printed on single slips for the use of music classes. The original form of the melody is in common time. Its first appearance in triple time seems to have been in R. A. Smith's 'Sacreil Music sung in St. George's Church, Edinburgh, I825.' There it is designated 'Old Seottish Melorly,' and the harmony is stater to be 'by Mr. Sunith.' It also appeared in The Seraph, a selection of Psalms and Hymns, edited by J. Robertson, and published in Glasgow in 1827 . There it is also in triple time, and a footnote states that "the above tme "Fenwick" or "Martyrdom," and by some ealled "Drumclog," was eomposed by Mr. IIugh Wilson, a native of Fenwick.'

The publication of the tune by R. A. Smith seems to have been the occasion of a legal dispute as to its ownership, but abundant evidenee was produced to show that Wilson was without doubt the composer. $\quad \Lambda$ bout fifty years ago a writer in The Psalmodist said, "I well remember the day it ("Martyrdom") was first sung in St. George's, Edinburgh, for Dr. Thomson then said to me, "O man! I could not sing for weeping."

Martyrs. Ps. 82.

The CL. Psalmes of David in Prose and Meeter: with their whole usuall Tunes, ete., Edinburgh, i615.

One of the 'xii. Common Tunes' which al'peared in this edition of the Scottish Book of Common Oriler. (See under 'Abbey.') Its first appearance in England seems to be in Ravenscroft's I'salter, 1621, where it is classed among 'Scottish 'Tunes,' and is in triple time. Playford and other English editor's follow Ravenscroft in this respect. In all the old books, 
both Seottish and binglish, the tune is in the Dorian mole as in the present bosk, but many elitols have introuluced changes into the tume in orler to force it into the morlern minor morle.

Maryton. 11 y. 205.

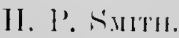

Chureh llymus with Tunes, 1874.

Compred for the hymm 'Sun of my soul.'

Meinhold. IIr. 3:3.

Lineburgisches fiesanghneh. . . . Limohnm, 1686.

Set to the hymn 'Jesus ist mein Aufenthalt,' as follows :-

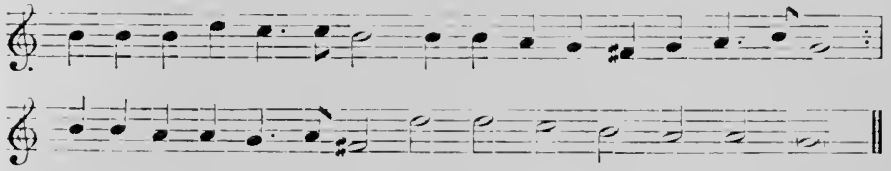

Later books exhibit variations in the melody. The present form is that foumd in J. s. Lach's Vierstimmige Cloralgesange, г 760 .

Melcombe. Hy. 135, 4s5, 511. Ps. 1:).

In Esiay on the Chureh I'lain Chant, I782. (Nee muler 'Alleste Fideles.')

The tme appears in the second part of the work, set to the words '() Salutaris hostia,' ete, and is heated ' At kxposition, levation, or benerliction of the bleserel Sacrament.' No composer's name is attacherl, hut in 'A Collection of Ilotetti, ctr.,'

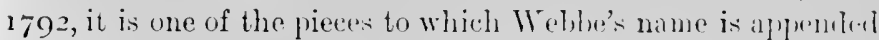
as composer. It appeared as a hymm tune unier its present name in vol. ii. of R. Itarrison's Sarerel Harmuny, publisher

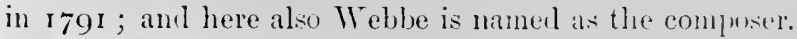

Melita. Iy. 509.

J. I. lYKES.

Ifyms Ancient and Morlern, 1861.

Composed for this hymm.

Melrose. Ps. 83.

The I'salmos of livirl in I'ruse and Mtroter: with their whole Tunes, etc, Elinburgh, 1635 .

This edition of the Scottish limk of Common (Orler contains thirty-one Common Tumes, of which 'Melroce' is No. 24. (See under 'Caithness.') 
Memoria. Hy. 417.

S. S. W ESLEY.

The Hymnary, i 872 .

Composed for the hymn ' $O$ Lord of heaven and earth and sea.'

Metzler. IIy. 132, 203.

R. Renhead.

Ancient Hymn Melodies and other Church Tumes as used at All Saints' Church, Margaret Street, arranged, composed, and harmonised by Richard Redhead, organist.

Preface dated Easter, 1859 .

Miles Lane. Hy. 91.

IV. Shrubsole.

The Gospel Magazine, November I 779 .

Printed with one verse of the hymn, but without author's or composer's names. Shortly afterwards the tune appeared in the Rev. Stephen Addington's Collection, under the name 'Miles's Lane'; Shrubsole being named as the composer.

Milton. Hy. 178.

W. H. LoNghurst.

Hymns Ancient and Modern. Supplement, I 889.

Composed for this hymn.

Minto. Hy. 505.

W. H. Monk.

The Church of England Hymnal, 1895.

Set to the hymn 'Art thou weary.' The tune was in MIS. at Dr. Monk's death, and was supplied by Mrs. Monk to I)r. Mann, the editor of the above book.

Miserere. Hy. 99.

II. H. Monk.

Hymns Aneient and Modern, I86r.

Composed for this hymn.

Misericordia. Hy. 175.

H. Sirart.

Hymns Ancient and Modern. Enlarged edition, I875.

Composed for this hymn.

Mistley. Hy. 214.

L. G. HAYNE.

The Merton Tune Book: $\Lambda$ Collection of Hymn Tunes used in the Church of St. Joln Iaptist, Oxford, compiled by the Rev. H. W. Sargent, M.A. Edited and arranged by the Rev. L. G. Hayne. Oxford, i 863.

Composed for the hymn 'Nearer, my God, to Thee.' 
Monica. Hy. 324.

M. I). Foster.

The Congregational Chmrch Iymmal, i 887.

Composed for this hymm.

Monkland. Hy. 395).

Iymms Ancient and Morlem, is6r.

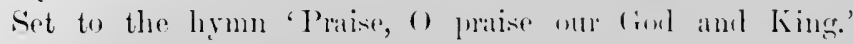
The tune is saicl to be 'arranged ly J. Wilkes', but its original has not been discovered.

Montgomery. IIy. 307.

I. WOODBURY.

The Choral Adrocate, i $8_{52} 2$.

Composed for this hymn.

Moravia. I's. 84.

The melorly from which this tme is clerived seems to have appeared in lavid Woller's New C'atedhsmus Gesanghichlein, Hamburg, I 598 .

since that date it has been includer in many German collections, but with very numerous variations. In J. S. Bach's Vierstimmige ('horalgesinge it appears as unler, and is referred to the hymn 'Aus meines Ilerzens Crmule.'
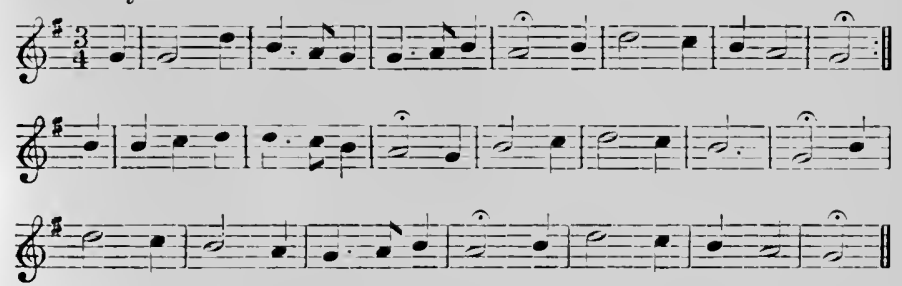

Moredun. IIy. 379.

II. SINART.

The P'reshyterian Hymmal, i 877 .

Comprosel for this hymn.

Morning. Hy. 36т.

II. II. MUNk.

The Scottish Hymnal, 187 .

Composed for this hymm.

Morning Hymn. IIy. 34:.

F. H. linthéléyon.

The Hymns and I'sahns used at the Asylum or House of Refuge for Female Urphans. Printed for W. Gawler, Organist to the Asylum, [1 789 ?]. 
Set to the present hymn, and hearled 'New Tume. Published by permission of Mr. Barthélémon.' 'The book las no date, but a copy in the possession of Dr. W. II. Cummings has the antograph of a fomer owner and the date 1789 . A previons edition of the work was publisher in 1785 ; in this the hymn is set to a different tune. In the Life of Barthélemon, by his clanghter, it is stated that 'about the year 1780 an arquaintance commenced between Mr. I;. and the Rev. Jacob Duché, then chaplain to the Asylum . . . one immediate consequence of this acquaintance was an application to Mr. B. to compose a hymn tune to "Awake, my soul.",

Morning Light. IIy. 267.

G. J. Wenis.

The Odeon: A Collection of Secular Melodies, designed for adult singing schools and for social music parties, by G. J. Webb and Lowell Mason, Boston, i $8_{37}$.

Set to a song beginning "'Tis dawn, the lark is singing.' Its first appearance as a hymn tune was in The Wesleyan Psalnist, I $8+2$.

Mors et Vita. $\mathrm{H}_{y} .326$.

J. STALNER.

The Church IIymnary, i 898 .

Composed for this hymm.

Moscow. Hy. 429 .

F. (riarinin.

A Collection of T'salm and IJymn Tunes, never published beforr, s 769 . Editel by the Rev. M. Madan.

Known as the 'Lock Collection.'

Composed for the hymn 'Come, Thou almighty King', and headed 'Hymn to the Trinity, set by F. G.'

In the original the last two lines read as under:-

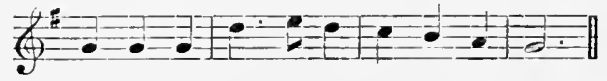

Mount Zion. Hy. 217.

1. S. Sullivan.

Psalms and Hymns for Divine Worship, I 867.

Set to the hymn 'Rock of Iges.'

Nachtlied. Hy. 362.

H. Silat'.

The Hymnary, 1872 .

Composed for this hymm. 
Nain. Hy. 167 .

L. MIASON.

Spiritual Songs for Social Worship . . . by Thomas Hastings of Boston and Lowell Mason of New York, i833.

Set to the present hymm in the following form -

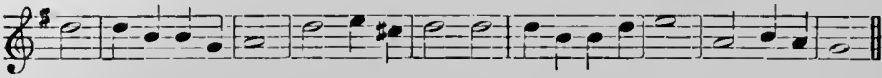

Nantwich. $\mathrm{H}_{y}, 516$.

T. R. MatThews.

The Clutreh of England Hymnal, i 895 .

Composed for the hymn 'Ye holy angels bright.'

Narenza. IIy. 277. Ps. 154.

Catholische Kirchen Gesiing . . . Cïlln, I6rg.

The melody of which the present tune is an adaptation is found in the above book, in triple time, set to the hymn 'Ave Maria klare, du liechter Morgenstem.'

In Töpler's Alte Choral-Melodien, I832, it appears as follows :-
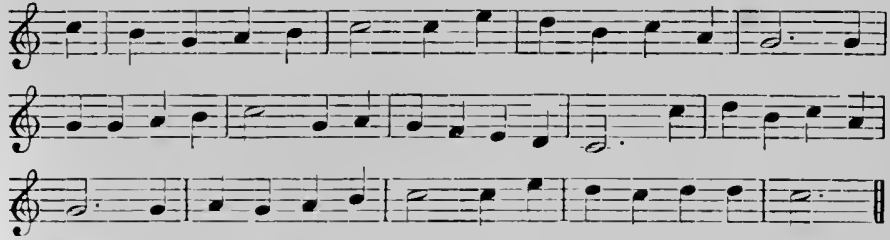

From this the present tune was arranged by the Rev. W. H. IIavergal, and published in his Old Chureh Psalmody, I847.

National Anthem. Ity. 511.

The origin of both words and music of this hymn is still, in spite of much investigation, very obscure. Its use as the National Anthem dates from about 1740 , in which year it was sung ly Henry Carey at a public dinner. About two years later both worls and tune were printed in Iarmonia Anglicana, and in 1745 they again appeared in the Gentleman's Magazine. In neither of these publications was the authorship of words or music attributed to Carey, and it was not till I 795 that his son George S. Carey claimed the anthorship for his father. Dr. Arne, who arranged the anthem for performance in I 745, stated that "it was a received opinion that it was written for 
the Catholic Chapel of James II.' On various grounds it is probable that this is the case, but although resemblances to the melody have been traced in various old English airs, its actual source is still undiscovered.

Nativity. Hy. 85.

II. LAHEE.

The Metrical Psalter ... Arranged for singing at each Sunday service throughout the year ... With Appendix of Hymns for Festivals . . . The Lusic arranged . . . by Henry Lahee, Organist of Brompton Church, [1855].

The present tune is in the Appendix, set to the hymn for Christmas Day 'High let us swell our tuneful notes.'

Ne Derelinquas Me. Hy. 385.

C. II. LloỲ.

The Children's Hymn Book, edited by Mrs. Carey Brock, I 88I. Composed for the hymn 'In the fair morning of our youth.'

Neander. Hy. 624.

J. Neander.

Joachimi Neandri Glaub- und Liebesuibung: Auffgemuntert durch Einfältige Bundes-Lieder und Danck-Psalmen ... Bremen, I68o.

Set to the hymn 'Unser Herrscher, unser König,' as follows :-
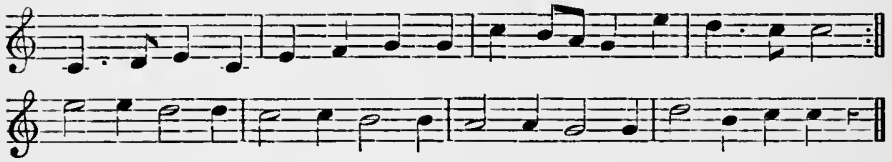

Nenthorn. Hy. Appx. 8.

T. I. IIately.

The Church of Seotland Hymn Tune 13ook, 1865.

Composed for this hymn.

Neumark. Hy. 278.

G. Neumark.

G. Neumarks .... Fortgepflantzter Musikalisch-Poetischer Lustwald. . . . Jehna, 1657 .

Set to the hymn 'Wer nur den lieben Gott lïsst walten,' as follows :-
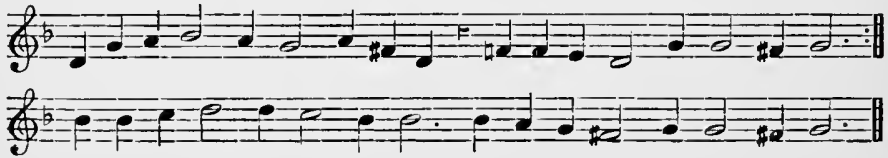
The present form of the melody is that adopted by Mendelssohn in 'St. Paul.'

New Calabar. Hy. 613.

J. Downing Farrer.

The Lowestoft Supplemental Tune Book, containing fiftysix Iymn Tunes. . . . Composed by J. Downing Farrer, I885.

Set to the hymn 'Come, my soul, thy suit prepare.'

New Year Morn. Hy. 483.

E. BuxinetT.

Twenty-four original tunes set to farourite hymns by Elwarl liunnett, i88o.

Composed for the hymn 'Welcome, happy moruing.' Original name of tune is 'Easter Morn.'

New 136th. Ps. 166.

A. L. P'EACE.

The look of P'salms and Paraphrases, with Tunes, by Authority of the General Assembly of the Chureh of Scotland, I 886.

Composed for Psalm 136 , first version.

$\Lambda$ slight alteration has been made by the composer on the tune as now printecl.

New 143rd. Ps. 171.

J. M. MELL.

The Bonk of Psalms and Paraphrases, i 886 (as above).

Set to I'silm 143 , second version.

Newcastle. Hy. 67 .

H. L. MORLEY.

The London Tune Buok, a Companion to all Hymnals now in use, [ ${ }_{1877}$. Eilited by Edwin Mloss.

Set to the hymn 'Eternal light! Eternal light!'

Newington. IIy. 403.

W. D. MaClaGaN.

IIymns Aneient and Morlern. Enlarged edition, 1875 .

Composed for this hymn.

Newington. Ps. 85.

Tr. JoNes.

Ten Chureh Pieces for the Organ, with four anthems in score, composed for the use of the Church of Nayland in Suffolk, by William Jones, i 789 .

The tune appears at the end of this work set to Psalm 23, and ealled 'St. Stephen's Tune.' Under the name 'Stephens' it appears in Knott's Sacred Harmony, Aberdeen, 1815. 
Newland. H.y. 64.

H. J. Gaunthett.

The Congregational Psalmist, edited by Dr. Henry Allon and H. J. Gauntlett, 1858 .

Nicæa. Hy. 1.

J. 13. DYKES.

Hymns Ancient and Modern, I86.

Composed for this hymn.

Nicolai. Hy. 116.

P. Nicolai.

Frewden Spiegel des ewigen Lebens ... durch Philippum Nicolai, Franckfurt am Mayn, I 599.

Set to the hymn 'Wachet auf, ruft uns die Stimme,' of which the present hymn is a translation. Both hymn and tune are believed to be by Nicolai.

The following is the melody as it is in the above book :-

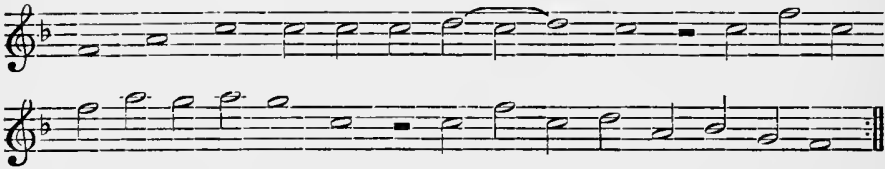

(2)

(3)

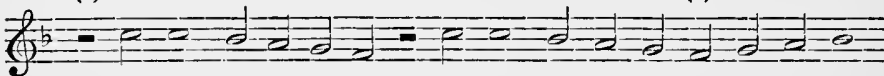

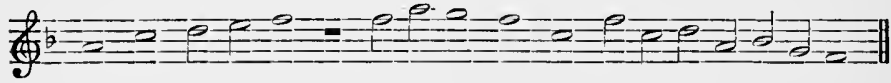

Owing, possibly, to misprints, there are some false rhythms in the above. To correct these Zahn suggests that the note at (I) should be a dotted semibreve, the rest at (2) should be omitted, and the note at (3) should be a semibreve. The present arrangement, both "as to melody and harmony, is substantially that adopted by Mendelssohn in 'St. Paul.'

Night Watch. Hy. 357.

J. Barniby.

The Hymnary, 1872.

Composed for this hymn.

Noel. Hy. 29.

Arr. by A. S. Sullivan.

Church Iymns with Tunes, I874.

The melody of the first four lines was given by a friend to Sir Arthur Sullivan, who edited the above book. He slightly 
altered the melody, harmonised it, and wrote the second half of the tune as it now stands, setting it to the present hymn.

Nomen Domini. IIy. 34.

Hin Gesangbueh der Brider in Behemen und Alerherm (Preface by Johann IIorn), Niimberg, I 54.t.

Set to the hymn 'O liebster I Ierr Jesu Christ.'

Inarmonised hy Sir John Stainer for The Chureh IIymnary.

North Coates. 11y. 258.

T. R. MATTHEW'S.

Congregational Melodies: $\Lambda$ Collection of Tunes ... by the Rev. T. R. Matthews, 1862.

Composed for the hymn "Glory be to Jesus, who in bitter priins.'

Northrepps. IIy. 5.2.2.

.. Jivotir.

The Congregational Chureh 11 ymial, 1887 .

Composed for the hymn '() Thou whose sacred feet have troul.'

Norton. 11 y. 598.

11. P'Afil.

Church of Eingland Psalmody, edited by the Rev. Ifenry P'ilr', is 86 .

The tune is there dated 1838 . It is not referred to any lymn in particular.

Norwich. I's. 86.

The Whole Booke of Psalmes . . Composed into four parts by sundry Authors. . . Newly corrected and enlarged by Tho. Ravenseroft, I6 2 .

Set to Psialuns 5, 55, and I02, the harmony being by John Milton, father of the poet. I slight change has been made in the last line, which in the original reads thus-

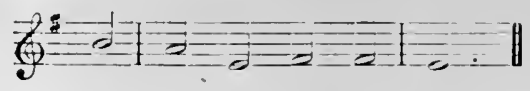

Nox Præcessit. Hy. 2:31.

J. li. CALKIN.

The Christian Hymnal. Five huntred Ilymns for the Cliureh and IIome, [1873].

Composed for the hymn "Jirile of the Lamb! awake, awake'; but in the same book it is also set to the present hymn, 
and a note states that it was adapted to that hymn by the composer.

Nun Danket. Hy. 20.

Praxis Pietatis Melica, edited by Johann Criger.

Of this famous collection between fifty and sixty editions were issued, dating from the middle of the seventeenth to the middle of the eighteenth century. Of the first two editions no copies have survived, but a single copy (wanting title-page) has been preserved of what is, on good grounds, believed to be the third edition, issued in 1648 . The present melody is found in this book, but it may have appeared in one or both of the earlier editions. It is set to the hymn 'Nun danket alle Gott,' of which the present is a translation, as follows:-
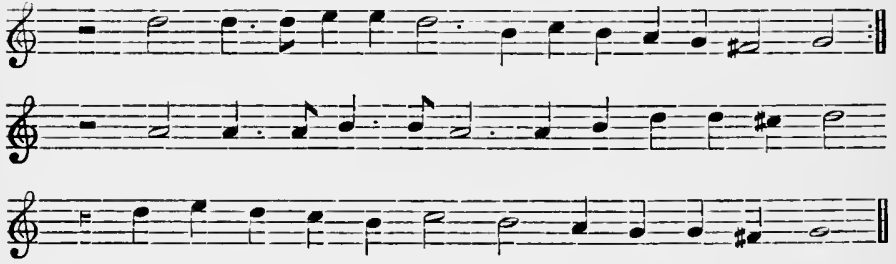

With slight variation, the hymn and tune are found in almost all German collections down to the present day. The arrangement here is substantially that by Mendelssohn in his 'Lobgesang,' the harmony being reduced from six parts to four.

Nutfield. Hy. 354.

IV. H. Monk.

Hymus Ancient and Modern, I86I.

Composed for this hymn.

o Filii et Filiæ. Hy. 79.

This melody and the hymn with which it is associated appear to be of French origin, and to date probably from the earlier part of the seventeenth century. The hymn is contained in the Office de la Semaine Sainte, Paris, I674, and the melody is found in slightly varying forms in books of the eighteenth century, including La Feillée's Methode Nouvelle pour apprendrc . . . les regles du Plain Chant. In a German Jesuit collection published in $167 \mathrm{I}$, entitled Nord-Sterns Fiihrers zur Sceligkeit, 
a German translation of the Latin hymn is given with the melody, as follows :-

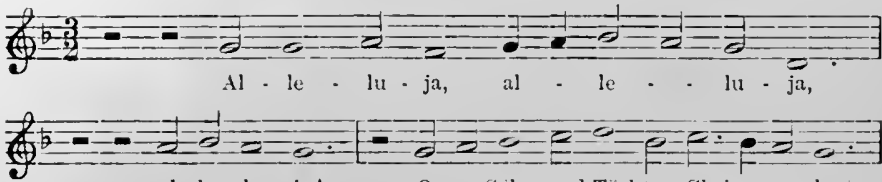

al - le - lu - ja !

o Solm und Töchter Chris-ten - leut,
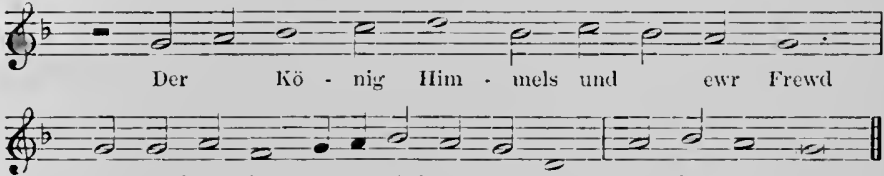

Fr-stand-en ist ron Torl - ten heut, Al-le - lu $\cdot$ ja:

The present form of the tune is slightly modified from that found in An Fssay on the Church Plain Chant, 1782, and Webbe's Collection of Motetts, I792.

O Perfect Love. IIy. 474 .

J. IiARBi.

Arranged from the anthem written for the marriage of the Duke and Duchess of Fife, 1889.

Composed for this hymn.

Oblation. IIy. 251.

J. IV. ElLLIOTT.

The Church Hymnary, 1898.

Composerl for this hymn.

Old 29th. I's. 141.

The forme of prayers and ministration of the sacraments, etc., used in the Englishe Congregation at (ieneval . . Geneva, 1556 .

This volume was issued for the use of the congregation of English and Seottish exiles which had been formed at Geneva, and of which John Knox was for a time co-pastor. It was known as the 'Order of Geneva,' and in its completed form was alopted by the Church of Scotland in 1564 as the 'Iook of Common Order.' The second portion of the rolume contains metrical versions of the psalms with the following title, 'One and Fiftic Psahmes of David in Englishe metre, whereof 37 were made by Thomas Sterneholde, ad the rest by others, etc.' These fifty- 
one psalms consist of forty-four by T. Sternhold and J. Hopkins which had been printed in England in $\mathbf{1} 549$, with seven by $\mathrm{W}$. Whittingham, one of the leaders in the Genevan congregation. Additions were made to the number of the psalms in 1560 and I 561, and the English and Seottish psalm books were completed in 1562 and $15^{64}$ respectively, the Scottish version forming a part of the Book of Common Order above referred to. The two collections are identical as regards about two-thirds of the entire number of psalms, but of the remainder different versions were adopted by the English and Seottish editors.

Each of the fifty-one psalms in the Genevan book is furnished with a tune, but nothing further is known as to the origin of these, nor as to who was responsible for the selection and arrangement of the musie in the volume. In later editions, notably that of I 561, a number of tunes were taken from the French Protestant Psalter.

The present tune is that set to Psalm 29. It was retained in all subsequent Scottish editions, but was not ineluded in the English Psalter.

\section{Old 44th. Hy. 265. Ps. 142.}

The forme of prayers, ete., Geneva, $155^{6}$.

See above, under 'Old 29th.'

The present is the tune of Psalm 44, and was retained in all subsequent editions both of the Scottish and English Psalm Books.

\section{Old 81st. Ps. 143.}

The Whole Booke of Psalmes . . . with apt Notes to synge the withal. . . . Imprinted at London by Jolnn Day, ${ }_{5}^{62}$.

This is the first complete edition of the English Metrieal Psalter. The present tume is set to the 81st and also to the 77 th Psalu, both of these versions appearing for the first time in this edition. In the complete Seottish book printed in $\mathbf{1 5}_{5} 64$, a different version of Psalu 8I was inserted and the tune is also different, but Psalm 77 is the same as in the English book, and is set to the present tune. There are some points of difference in the tune as printed in the various editions, the chief of these being that it is sometimes in common and sometimes in triple time. 
Old 100th. Hy. 380, 634. Ps. 14, 15.

Pseaumes oetante trois de David, nis en rime Francoise. A savoir quarante neuf par Clement Marot. . . . Et trente quatre par Theodore de Besze . . . A Geneve, 155 I.

As stated under 'Commandments,' the Metrical l'salter of the French Protestant Church was of gradual growth. In I55 I appeared the first instalnent of the work of Theodure liezal, consisting of thirty-four psalms. Among these was the $13+$ th, and the present melody is attached to that psalm. Its original form is as follows:-

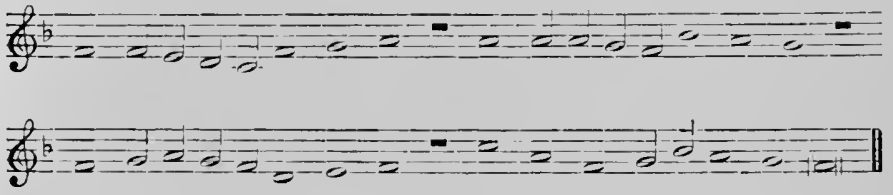

The first edition of the Anglo-Genevan Psalter in ${ }^{5} 55^{6}$ (see under 'Old 29th') diel not contain any version of P'salm 100. That by William Kethe, 'All people that on earth do dwell,' appeared in an edition printed at (ieneva in 1561 , containing eighty-seven psalms, and in another printed at London the same year, containing eighty-three psalms. It is an unsettled point which of these two editions was issued first. In both of them the present tune is attached to this $\mathrm{l}_{\mathrm{s}} \mathrm{alm}$, and has ever since remained indissolubly assoeiated with it.

Old 124th. Ps. 176.

This tune appears in the 1551 edition of the French Metrical Psilter. (See above under 'Old Iooth.') It is set to the version of P'salm i 24 , one of the thirty-four lyy Theorlore lieza. The linglish rersion hy William Whittinghan, which with slight changes is that still in use, is found set to the present tune in an edition containing sixty-five psalms printed (probably in England) in 1560 ; but there is ground for supposing that it alpeared two years previously in an edition issued in Geneva, of which no copy has yet been discovered. Whittingham certainly based his version on the French, probably with the view of its being sung to 
the French tune. This will appear from a comparison of the opening verse in the two versions. Beza's is-

Or peut bien dire Israel maintenant

Si le Seigneur pour nous n'enst point esté

Si le Seigneur nostre droit n'eust porté

Quand tout le monde à grand' fureur renant

Pour nous meurtrir dessus nous s'est jetté.

W'hittingham's is (spelling modernised)-

Now Israel may say, and that truly,

If that the Lorl had not our cause maintained;

If that the Lord liad not our right sustained,

When all the world against us furiously

Made their uproars and said we should all die.

It is a curious faet that although the Scottish Reformers in compiling their Psalm Book were largely indebted both as regards words and music to the Church of Geneva, yet this is the only case in which from the Reformation to the present day the same psalm and tune have eontinued to be used together in the churches of John Calvin and John Knox. Two incidents in which the psalm and tune have a place may be referred to, one being from Genevan, the other from Scottish history. One of the last attempts made by the Dukes of Savoy to crush the Protestant movement, and reconquer the town of Geneva was made in 1602, and is known as the Escalade. The attack was repulsed by the bravery of the eitizens, and when the confliet was over, Theodore Beza, then eighty years of age, returned thanks for the victory, and gave out the r 24th Psalm to be sung. Sinee then it has always been sung in Geneva, on the I 2 th Deeember, the anniversary of this event; and on a monument erected to commemorate the same, one of the reliefs represents Beza at the door of the cathedral giving out the psalm. The other incident is the well-known one connected with John Durie, one of the ministers of Edinburgh, who was banished from the eity for using too great freedom of speech against the king's designs. On $4^{\text {th }}$ December $15^{82}$ he re-entered the eity amid the rejoicing of the populace, the scene being thus described by Calderwood: 'At the Netherbow they took 
up the r 24th Psalme, "Now Israel may say," etc., and sung in such a pleasant tume in four parts, known to the most part of the people, that coming up the street all barehealed till they enter in the kirk, with such a great sound and majestie that it movel both themselves and all the huge multitule of the beholiters, looking out at the shots and over stairs, with admiration and astonishment. The Duke (Lennox) himself beheld and reave his beard for anger: he was more affrayed at this sight than anie thing that ever he had seene before in Seotland.'

Old 134th. Hy. 115. P's. 15.5.

The tune of which this is an adaptation appeared in the 1551 edition of the French Metricil Psalter. (See abuve under 'Old rooth.') It is set to the version of I'salm ror by Marot (replacing a ditherent tume fomel in the earlier editions), and is as follows:-

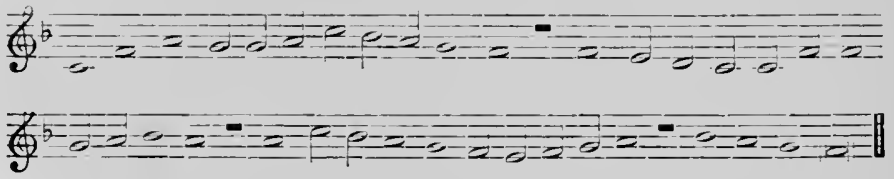

In the $\mathrm{I}^{6} \mathrm{G}$ edition of the Anglo-Genevan Psalter, the tune aphears as muler, set to P'silm 134 :-
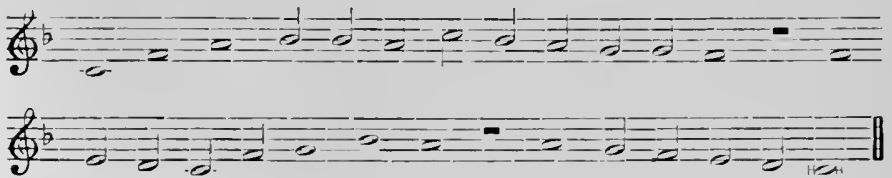

Possibly the fourth and fifth notes here are due to a mispint, as those of the origrinal (G instean of 1 ; flat) are restored in all other editions. With the exception of these two notes, this form of the meloly is retained in all the elitions of the seottish P'salter, but those of the Engrish P'salter show some variations. In all of these the thirl line is the same as at present, while line $t$ is fouml in two forms. The earlier ellitions from $\mathbf{1 5 6 2}$ have

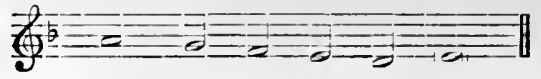


but from 1577 the form adopted in nearly all editions is

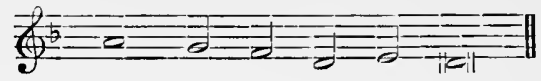

The present form of the tune, and also the name 'St. Michael,' by which it is usually known in England, are probably due to Dr. Crotch.

Old 137th. Ps. 144.

The forme of prayers, etc., Geneva, $155^{6}$.

See above under 'Old 29tlı.'

The present is the tune of Psalm 137, and was retained in all subsequent editions, both of the Scottish and English Psalm Books.

Olivet. Hy. 197.

I. Mason.

Spiritual Songs for Social Worship ... Words and Music arranged by Thomas Hastings of New York and Lowell Mason of Boston, 1833 .

The hymn having been given by the author, Dr. Ray Palmer, to Dr. Mason, the latter composed the present tune for it, and published it in the above collection.

Ora, Labora. $\mathrm{Hy} .253$.

R. P. Stewart.

Church Hymnal (authorised by the Irish Episcopal Church), I 874 .

Composed for this hymn.

Oriel. Hy. 37, 453.

Cantica Sacra in usum Studiosæ juventutis. Collegit et edidit J. Nichael Nauber . . . Cantui Chorali accommodavit vocem organi Casparus Ett, Regiæ Ecelesiæ aulicæ ad S. Michael Monac. organoedus, Monachii, 1840.

Set in four parts to the hymn 'Pange lingua gloriosi.' It is not quite certain whether the tune was entirely composed by Ett, or only arranged by him; but it has not been tracel to any earlier source. In Easy Music for Church Choirs, P'art III., 1853 , Ett is named as the composer.

Orientis Partibus. Hy. 432.

In some parts of France, notably at Beauvais, during the 
Niddle Ages, there was celebrated on the It January a church festival known as the Feast of the Ass. It was intended to commemorate the flight into Egypt. On this occasion a young woman holding a child in her arms was seated on an ass, and after a procession through the streets of the town, the ass, with its burlen, was led into the principal chureh and took its stand beside the high altar while mass was celebraterl. During the service a hymn was sung, written in a mixture of mediæval Latin and old Freneh, of which the first lines were 'Orientis partibus adventavit asinus.' The melody of this hymn has been preservel, and from it the present tune was alapted, and published by R. Redhead in his Church IIymn Tunes, I 853. M. Félix Clément has tracel the melody to a manuseript preserved in the Library of Sens, entitled 'Office de la Circoncision it l'usage de la ville de Sens.' In his Notice sur les Chants de la Sainte Chapelle, I 852 , M. Clément states that this 'Office' is the work of Pierre cle Corbeil, Arehbishop of Sens, who died in r 222. Ife further says: ' Among the items composing this office, there is a piece which has been ealled "Prose of the Ass" ("Prose cle l'ane"). Nothing in this piece justifies the opinion, which several writers hostile to Catholieism have endeavoured to maintain in regard to a feast, in which the ass played a burlesque and ridiculous rôle. The French refrain, and two of the verses eited by IIM. Dulaure, Millin, and Miehelet, do not exist in the Sens manuscript, which is older by two hundred years than that of lieaurais, which these historians have consultell. . . . These writers have taken the parody of the Prose for the Prose itself.' The melody, as quoted by M. Clément, is as follows:-
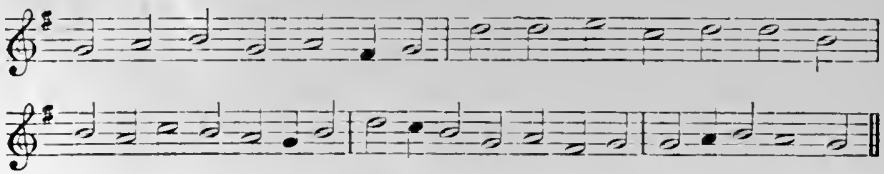

Oxford. IIy. 196.

J. Stainelk.

The Ifymnal Companion to the Book of Common Prayer. Third edition, I 890 .

Composed for this hymn. 


\section{Palestrina. Ps. 87.}

An adaptation from the 'Gloria Patri' of the 'Magnificat Tertii Toni,' contained in the work entitled 'Magnificat Octo Tonorum,' published by Palestrina in I 591 .

The music seems to have been arranged as a hymn tune for the first time in the Parish Choir, $185 \mathrm{I}$, the metre being in six lines of eight syllables each. The present arrangement as a C.M. was made by T. L. Hately, and appeared in The Church of Scotland Hymn Tune Book, I862.

Paradise. Hy. 335.

H. SMART.

Hymns Aneient and Modern. Appendix, r 868.

Composed for this hymn.

\section{Pascal. Hy. 191.}

Katholisehes Gesangbuch, auf allerhöchsten Befehl Ilırer k. k. apost. Majestät Marien Theresiens zum Druck befördert. Wien, im Verlag der katechetischen Bibliothek. (This book has no date, but from internal evidence it cannot be earlier than I774, nor later than 1780, the year of Maria Theresa's death.)

The origin of this melody is still obseure. So far as at present known, the above book contains its earliest appearance as a hymn tune. It is set to the hymn 'Grosser Gott, wir loben dich,' as follows :-

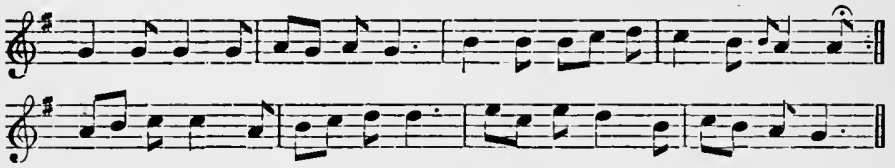

It is associated with the same hymn in many later German books, both Catholic and Protestant. Its earliest appearance in a Protestant collection seems to be in Schicht's Choral-Buch, published at Leipsie in I8I9. .It is there set to the above words in the following form-
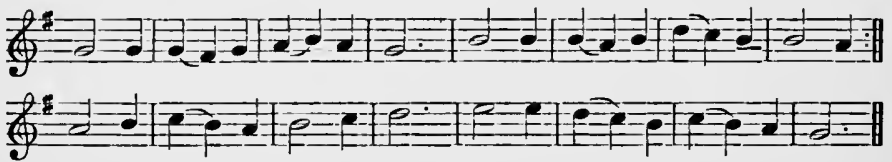
The choral-book edited by Jakob and Riehter in 1873 contains a setting of the melody ascribed to Peter Ritter, a Mannheim musieian born in 1760 . This gave rise to the opinion, which had the support of the late I)r. Rimbault, that the tune was composed by Ritter; but it is hardly conceivable that a melody by Ritter conld appear in a book published in Viemna while the composer was still in his teens. Further, the tune appears in several German books issued during Ritter's lifetime, and in none of them is he designated as the composer.

The tune seems to have been first set to English words in vol. ii. of the Serpuel to Weyman's Melodia Sacra, published in I) 'Stillorgan,' in the form now known as 'IIursley,' and is set to the hymn 'Jesus, and shall it ever be.' The name 'Hursley' is that of the parish of which the Rev. J. Keble was vicur, and it was doubtless given to the tune when it came to be associated with his hymn 'Sun of my soul.'

Passion Chorale. IIy. 6s.

H. I. IIASSLER.

Lustgarten Neuer Tentscher Gesing . . . Componirt dureh IIanns Leo Ilassler von Niumberg, I6or.

The melarly is here set to a secular song begimning 'Mein Gmüt ist mir verwirret,'an follows :-
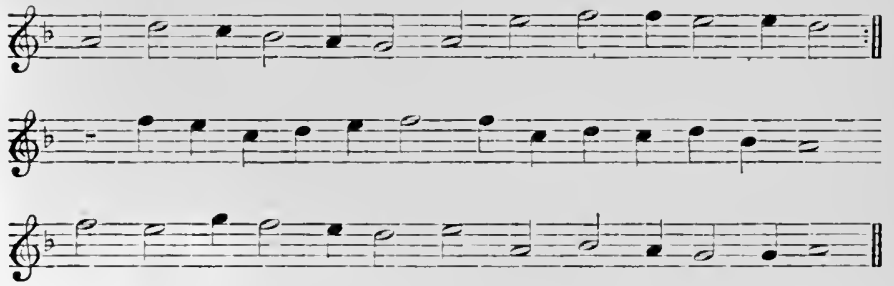

In Harmonix Sacrm, Gorlitz, 1613, it is set to the hymn 'Ierzlich thut mich verlangen,' and in later books it is generally associated with 'o Jaupt voll I'lut ant Wunden,' of which the present hymn is a free translation. Jach used the clorale five times in his 'St. Matthew Passion.' The form of the melody used by him is that adopted here, and the harmony is also mainly his. 
Pax Dei. Hy. 617.

J. B. DyKes.

Hymns Ancient and Modern. Appendix, 1868.

Composed for this hymn.

Pax Tecum. Hy. 226.

G. T. Catdbeck.

The Hymnal Companion to the Book of Common Prayer. Second edition, 1877 .

Composed for this hymn. The MS. was sent by Mr. Caldbeck to the author of the hymn, the Rev. E. H. Bickersteth, who included it in the above book, of which he was the editor. The tune was slightly altered before publication.

Pearsall. Hy. 160.

R. L. De Pearsall.

Katholisches Gesangbuch ... zum Gebrauche bei dem öffentlichem Gottesdienste. Herausgegeben vom bischöflichen Ordinariate des Bisthums St. Gallen, St. Gallen, I863.

The work contains five settings of hymns for the service of the mass. The present tune is that of the Sanctus in the first setting, the German words beginning 'Singt Heilig, heilig, heilig, ist unser Herr und Gott.' No composers' names are attached to the tunes, but the preface states that this tune was composed by Pearsall, who also harmonised about half of the tunes in the work.

Penitence. Hy. 166.

W. II. Monk.

The Scottish Hymnal, i 87 .

Composed for this hymn.

\section{Per Recte et Retro. Hy. 381 .}

J. StAlNer.

The Church Hymnary, 1898 .

In the tune lines 3 and 4 consist of lines $\mathrm{I}$ and 2 read backwards in all the parts. This is the first instance in which this device has been carried out in a hymn tune.

Peterborough. Hy. 13. Ps. 26.

J. Goss.

The Church Psalter and Hymn Book, edited by Rev. Wm. Mercer. Rearranged edition, I864.

Peterborough. Ps. 88.

Sacred Harmony ; or, A Collection of Psalm Tunes Ancient and Modern, edited by R. Harrison, vol. ii., I79I. 
The original form of the melody is as follows:-

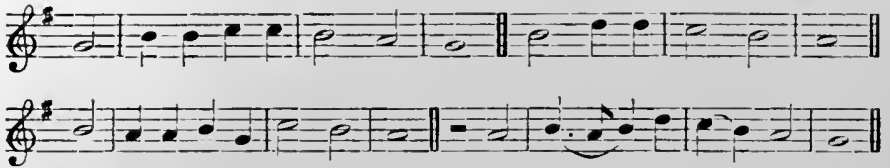

The rhythm of the above is faulty ; probally the first notes of lines I and 3 are misprinted, and should be semibreres.

Petersham. IIy. 123. Ps. 145.

C. II. PoOle.

The Congregational Psalmist, edited by Dr. Henry Allon. Second Appendix, 1875 .

Set to the hymn 'The roseate hues of early dawn.'

Petra. Hy. 191.

R. RenHeAD.

Chureh Iymn Tunes, Aneient and Modern, for the several seasons of the Christian Year. . . selected, composed, and edited by Richard Rerlhead, 1853 .

Referrel in the Index to the present hymn.

Pilgrim Band. Iy. 580.

J. STAINER.

The Church IIymnary, I 898 .

Composed for this hymn.

Pilgrims. Hy. 308.

II. SyART.

IIymus Ancient and Molern. Appendix, I 868.

Composed for this hymn.

Playford. Ps. 16.

Psalms and Hymns in Solemn Musick of Foure Parts. . . . By John P'layford, 1671.

Set to Psalm I 2 , the version by Bishop Ilenry King, ' $\mathrm{C}_{\mathrm{P}}$ to the hills I lift mine eyes.'

This tume is not found in any of the earlier metrical psalters, nor does it appear in l'layford's Whole look of I'salms, I677.

Potsdam. Ps. 156. Alapted from J. S. PACH.

An adaptation from the subject of the Fugue in $E$, of the ' 48 Prelurles and Fugues.'

Prætorius. 11y. 85. Ps. 89.

Harmonicæ hymnorum seholæ Gorlicensis, Gorlitz, 1599. 


\section{4 THE MUSIC OF THE CHURCH HYMIARY}

Set to the hymn 'Fuir dein empfangen Speis und Trank,' as follows :-

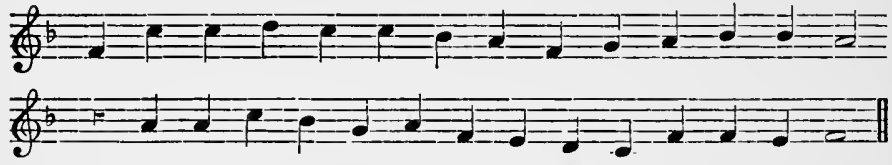

The tune appears in M. Prætorius's Musæ Sioniæ, Part VI., r6o9, and was thought to be his composition; hence its present name.

Prague. Ps. 157.

L. R. WEst.

The Hymn Tunes of the Church of the Brethren. . . Arranged for Four Voices in Score, by John Lees, 1824.

Praise. Hy. 15.

E. J. Hopkins.

The Hymnary, 1872.

Composed for the hymn 'Every morning mercies new.'

Praise, My Soul. Hy. 18.

J. Goss.

The Supplemental Hymn and Tune Book, compiled by the Rev. R. Brown-Borthwick. Third edition, with new Appendix, [i 869].

Composed for this hymn. The tune is given in the above book both as here with the varied arrangement of the several verses, and also in four-part vocal harmony, the latter setting being in key $\mathrm{E}$.

Propior Deo. Hy. 237.

A. S. Sullivan.

The Hymnary, i 872.

Composed for this hymn.

Protection. Hy. 402.

F. C. MAKER.

The Bristol Tune Book. Third series, 189I.

Composed for this hymn.

Quam Dilecta. Hy. 373.

H. L. JENNER.

Hymns Ancient and Modern, I86I.

Composed for this hymn.

Rabenlei. Hy. 564.

J. C. H. Rink.

L. Erk's Weihnachtslieder, Berlin, [1850?].

Set to the hymn 'Alle Jahre wieder,' and headed 'Mel. 
von Christian Heinr. Rinck, 1827.' It has not been ascertained whether this is its original form, nor in which of Rink's published works the melody appeared.

Radford. Hy. 371 .

S. S. MEsLEY.

Church 11 ymus with Tunes, I874.

Composed for this hymn.

Raleigh. $\mathrm{Hy}$. 506.

E. Prout.

The Congregational Chureh Iymnal, r 887.

Set to the hymm 'I bring my sins to Thee.'

Ramoth. IIy. 623.

J. I?. Calisis.

The Supplemental Ilymn and Tune Book, compiled by the Rev. R. Brown-Borthwick. Third edition, with new Appendix, [i 869].

Composed for the hymm 'I.ord, to Thee alone we turn.'

Ratisbon. IIy. $3+4$.

Choralbuch zu den neuen sächsischen Gesangbiichern ... vou Johann Gottlob Werner, Leipzig, i $8 \mathbf{I}_{5}$.

Set to the hymn 'Jern, meines Lebens l.eben,' as follows:-
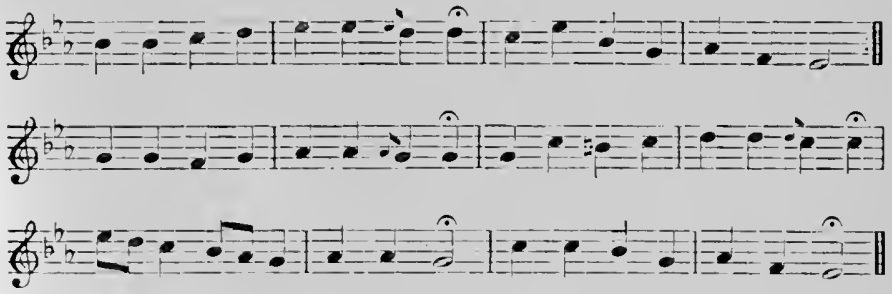

This is, howerer, largely an alaptation of an oleler melody which is found in Neander's Choralbuch, I680, to the hrmu ' (irosser Prophete, mein llerze begehret,' as fullows :-
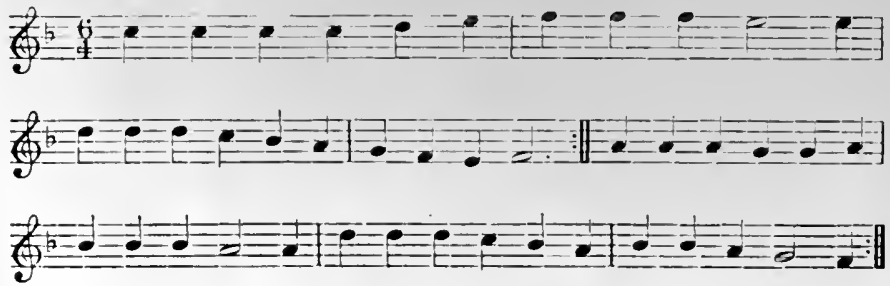
I 6 THE MUSIC OF THE CHURCH HYMNARY

Ravendale. By. 497 .

T. R. Matthews.

The North Coates Supplemental Tune Book, 1874.

Composed for the hymn ' $O$ Thou from whom all goodness flows.'

Ravenna. By. 392.

J. H. KNECHT.

Vollständige Sammlung . . . Choralmelodien . . Herausgegeber vo Christmann ind Knecht, Stuttgart, I799.

Set to the hymn 'One Rest ind unverweilt.' The melody is exactly the same as the present tune, with the exception of the second note of line 3 , which in the original is flattened (Ft in the present key).

Ravensburg. Ps. 90.

F. Silloher.

Vierstimmige Gesänge der evangelischen Kirche, Stuttgart, 1825 .

Set to the hymn 'Preis ibm, er schuf and er erhält,' as under :-
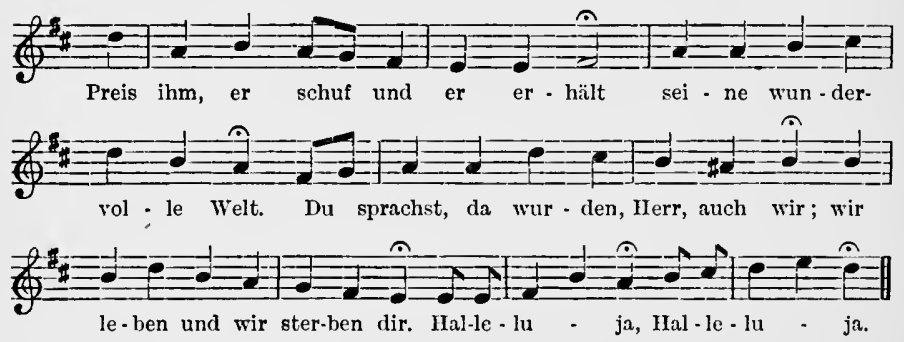

Ravenshaw. Wy. 153.

Fin New Gesengbuchlen, I 53 .

The earliest German hymn book of the Bohemian Brethren, edited by Michael Wise.

Set to the hymn 'Menschenkind, mark eben,' as follows :-
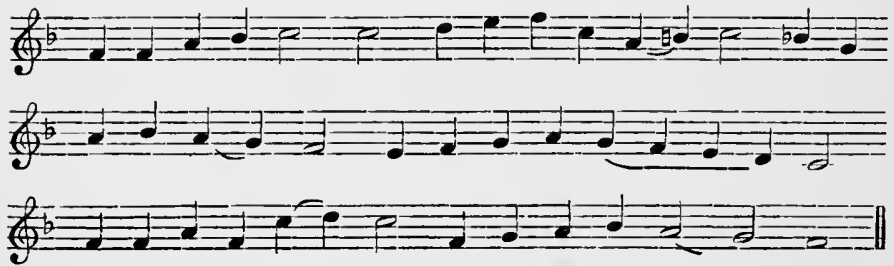
The original has no $b$ in the signature, but this is supplied in the subsequent editions of this book. The melody is of preReformation origin, and was associated with the Latin hymn beginning 'Ave Hierarchia, coelestis et pia.' The present arrangement by Dr. Monk appeared in Ilymns Ancient and Modern, I86ı.

Redemption. Hy. 37, 631 .

C. Govion.

The Hymnary, 1872 .

Composed for the hymn 'Lo, He comes.'

Redemption. Ps. 223.

A. M. Tuouson. Sacred Harmony for the use of St. George's Church, Edinburgh, 1820 .

Composed for Paraphrase 44, vers. $3^{-6 .}$

Regent Square. Jy. 10, 414.

II. SyarT.

Psalms and IYrmes for Jivine Worship, 1867 .

Set to the present hymn (No. Io).

Remembrance. IIy. 170.

J. Bootir.

The Church Iymnary, i 898 .

Composel for this hymm.

Repose. $\mathrm{Iy} .35 \%$.

J. Stainer.

The Westminster Abbey Hymm Book, I 897.

Composel for this hymm.

Requiem. $\amalg_{y}, 321$.

J. IjARNBY.

The Sarum Iymnal, with proper tumes. The Music edited by T. E. Aylwarl, i 869.

Composel for this hymn.

Requiem. Hy. 427.

IV. Schulthes.

Oratory Iyrm Tunes, arranged by Wr. Pitts, Organist at the Oratory, [I87 I].

Headed 'Consolatrix Afllictorum,' and set to the hymm 'Like the voiceless starlight falling.' It was set to the present hymn in the enlarged edition of Iymus Aneient and Modern, i 875 .

Requiescat. $\mathrm{Hy}_{\mathrm{y}} 325$.

J. I). DYKES.

Iymns Aneient and Modern. Enlarged edition, 1875.

Composed for this hymn. 
Rest. Hy. 234, 337 .

J. STAINER.

The London Church Choir Association Festival Service, I873.

Composed for the hymn 'Thou hidden love of God,' No. 234.

In Hymns Ancient and Modern, enlarged edition, 1875, the tune was set, under the composer's sanction, to 'The saints of God, their conflict past,' No. 337 .

Rest. Ps. 91.

The Hallelujah, edited by Dr. Lowell Masoll, 1854 .

The present tune is an adaptation by Mr. William Carnie of $A$ berdeen from a tune named 'Millbury' in the above collection, where it is anonymous.

Reynoldstone. Hy. 419.

T. R. MatThews.

Composed for the hymn 'Rock of Ages.'

Printed in a collection of 'Sixteen Tunes' by Mr. Matthews, which was sold in aid of the rebuilding of North Coates Church in 1865 .

Riseholme. IIy. 179.

II. J. Gauntlett.

Composed in I87 I for the hymu, by Bishop Wordsworth, 'Father of all, from land and sea.'

Dr. Julian (Dictionary of Hymnology) states that the hymn was 'written by request after the Nottingham Church Congress, i87 r, and set to music by H. J. Gauntlett.'

Rivaulx. Hy. 2.

J. B. DYKes.

A Hymmal for use in the English Church, with accompanying Tunes, i 866 . Edited by the Hon. and Rev. J. Grey.

Composed for this hymu.

River of Life. $11 \mathrm{y} .594$.

J. STAiner.

The Church IIymnary, 1898.

Composed for this hymn.

Rochester. Hy. 141. Ps. 17.

The Whole Booke of Psalmes, collected into Englysh metre .. with apt notes to synge the withal . . Imprinted at London by John Day . . $\mathbf{1 5 6 2 .}$

The statement that the present tune is contained in the above work appears to rest on the authority of the late Dr. 
Henry Allon, who published the tune in the Congregational Psalmist, 1858 . In his preface to that work, Dr. Allon gives a full description of the 1562 Psalter, and says ' $a$ copy of it now lies before me.' Unfortunately, however, this copy cannot now be traced, and no other is known. If it is the case that it contains 'Rochester,' it is somewhat singular that the tune is not to be found in the editions of the Psalms published by Day in $1_{5}{ }^{6} 3$ and $1_{5}^{6} 4$, nor inteed in any of the subsequent editions of the 'uld Yersion.'

Rock of Ages. Hy. 191.

Neu-rermehrtes . . . M einingisches Gesangbuch, Meiningen, 1693 .

Set to the hymn ' Nicht so traurigr, nicht so sehr,' as follows :-
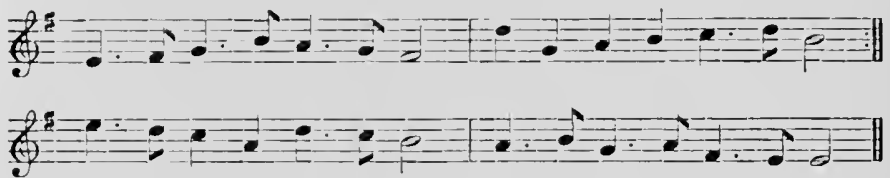

Arranged by Sir John Stainer for The Chureh Iymnary.

Rossall. Hy. 62.

E. T. Sineting.

The Church Hymnary, 1898 .

Composed for this hymm.

Rothley. Iy. 449.

J. Goss.

The IIymnary, is 72.

Composed for the hymn 'Our blest Redeemer, e'er lle breathel.'

Rousseau. Hy. 605.

J. J. Rousseat.

An adaptation from the following melody in his opera, 'Le Devin du Village,' performed for the first time in $175^{2}$ :-
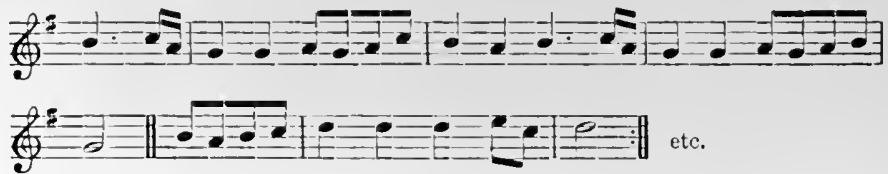

It is set to the present hymn in Sacred Melodies for Chilkren, I $8_{43}$, edited by the Rev. C. II. Bateman. 
Ruth. Hy. 493.

S. Sмith.

Composed for the hymn 'Earth below is teeming,' and printed in a collection issued by the composer for private circulation in 1865 .

In Church Hymns, 1874 , it is set to the present hymn.

Rutherford. Hy. 306.

C. Urhan.

Chants Chrétiens, Paris, r834.

Set to the hymn 'Eternel, O mon Dieu, j'implore ta clémence,' as follows:-
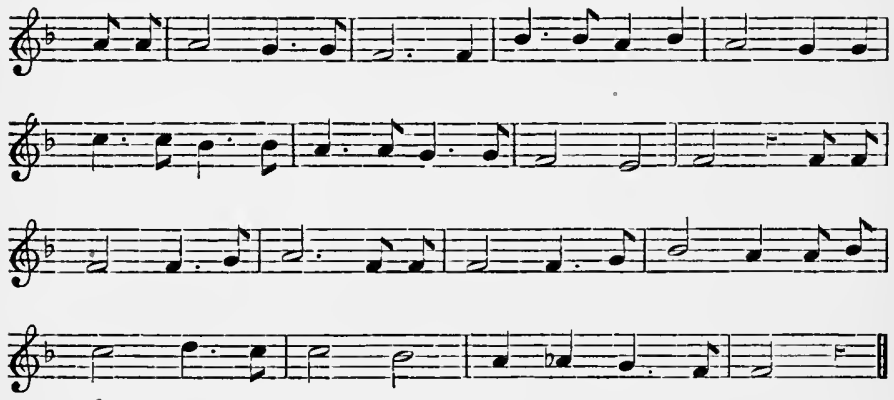

The present arrangement appears in Psalms and Hymns for Divine Worship, r867, and was made for that work by Dr. E. F. Rimbault.

Ruthwell. Hy. 127.

J. M. BeLL.

The National Book of Hymn Tunes, etc., $188_{5}$.

Composed for this hymn.

Sacrifice. Hy. 515.

H. LAHEE.

One Hundred Hymn Tunes, edited by H. Lahee, 1867.

This collection was compiled for use with the $\mathrm{II}_{\mathrm{m} m \mathrm{~m}}$ Book edited by Dr. W. J. Irons, r 866.

The present tune is not referred to any particular hymn.

St. Aëlred. Hy. 44.

J. I. DYKes.

The Congregational Hymn and Tune Book, edited by the Rev. R. R. Chope, I862.

Composed for this hymn. 
In the above book the last line is in common time, and ends in minor, thus-

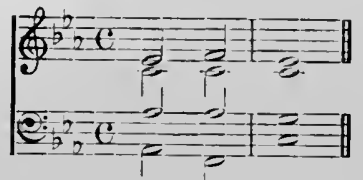

It was altered to the present form by the composer when included in the Appendix to IIymns Ancient and Iodern, I 868.

St. Agatha. Hy. 188.

F. Soltilgate.

Favourite Ifymn Tunes . . used at St. Botolph's Church, Northfleet, London, $\mathrm{I}_{7} \boldsymbol{7}_{3}$.

Composed for the hymn 'Lord of merey and of might.'

St. Agnes. IIy. 415.

J. LAsgras.

Composed for the hymn 'Abide with me,' and published in seprarate form in 1861 . Thereafter it appeared in I'salms and Ilymns adipted to the services of the Church of lingland, with aceompanying tunes selected and revised by Juhn Foster, I863. (S.e under 'Deerhurst.')

The tune is there set to 'Abide with me,' and is named 'Evensong.'

St. Agnes, Durham. IIy, 202. Ps. 92. J. 13. I)КEs. A IIymnal for use in the English Church, with accompanying Tunes, i 866. Edited by the IIon. and Rer. J. Grey.

Composed for this hymn.

St. Aidan. IIy. 413.

IV. II. Musk.

Hymns Ancient and Modern. Enlargod edition, I 875 .

Composed for this hymn.

The tune is without a name in Ifymns Ancient and Modern. Present name first given in The Chureh Hymnary.

St. Alban. Hy, 406.

The St. Albans Tune 1jook, [circa I 866]. Eilited by the Rev. H. A. Walker.

Dr. Ball, Provost of Cumbrae College, writes regarding this tune: 'It was written sometime in the fifties, I think, by 
a Mr. (G. ?) Fleet, at that time Secretary of the Church of England Sunday School Institute, and the tune was originally published in some magazine issued by that Society. . . . I gave the tune to the Rev. H. A. Walker or to T. Morley, who re-harmonised it.'

St. Albinus. Hy. 80.

H. J. Gaunthett.

The Church Hymn and Tune Book, edited by W. J. Blew and H. J. Gauntlett, $185^{2}$.

Composed for an Easter hymn 'Angels to our jubilee.'

The second form of the tune here corresponds with the original; lines 5 and 6 of the first form were added by the composer for the Presbyterian Hymnal, I 877.

St. Alphege. Hy. 332, 472.

H. J. Gauntlett.

The Church Hymn and Tune Book, edited by IV. J. Blew and H. J. Gauntlett, 1852 .

Set to the hymn 'The hymn of glory sing we.'

St. Ambrose. Hy. 139.

IV. H. Monk.

The Hymnal, with Tunes old and new. New York, 1874. Edited by the Rev. J. Ireland Tucker.

Composed for the hymn ' $M y$ faith looks up to Thee.'

St. Ambrose. Hy. 384, 410.

C. Steggali.

Chureh Psalmody, edited by Charles Steggall, I 849 .

Tune is dated 1847 .

St. Anatolius (I.). Hy. 364 .

A. H. Brown.

Composed for this hymn, and published along with eight other tunes by the same composer in I862, under the title 'The Day is past and over; an Evening Hymn, to which are added a few other hymns.'

St. Anatolius (II.). Hy. 364.

J. B. DYKEs.

The Congregational Hymn and Tune Book, edited by the Rev. R. R. Chope, I 862.

Composed for this hymn.

St. Andrew. Hy. 40.

E. H. Thorne.

Hymns Ancient and Modern. Enlarged edition, I875.

Composed for this hymn. 
St. Andrew. Ps. 93.

The New IIarmony of Sion . . by IV. Tans'ur. Book II. 1764 .

Set to Psalm ${ }^{5} 5^{\circ}$, and healed 'Barby Tune, eomposed in four parts, Wr. T.'

St. Anne. IIy. 21, 47̄, 635. P's. 94.

II. Croft.

A Supplement to the New Version of Psalms by Mr. Brady and Mr. Tate. ... The Sixth Edition, corrected and much enlarged . . . 1 708 .

The tune, with its present name, is set to the new version of Psalm 42, in two parts, treble and bass, as follows :-
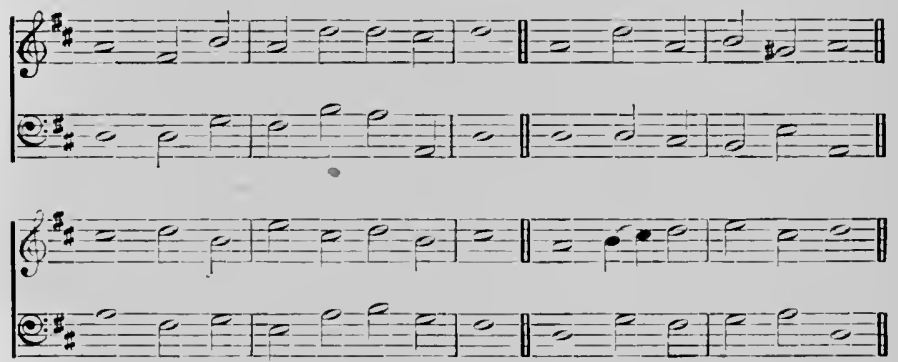

It is market in the Intex as a new tune. To composers' names are given in the above work, lut it is generally believed that Dr. Croft was eoncerned in its production, and the present tune has been almost universally attributerl to him. It is found with his name attached to it in Melodies I'roper to be sung to any of $y^{e}$ versions of the P'salms of David, edited by Philip Iart, and puldished about 1720 ; and also in 1 In Introduction to Psalmody, by John Chureh, published in 1723 . Both of thiese editors were contemporaries of Croft, and the latter was master of the chorister's of Westminster Abbey while Croft was organist there.

St. Anselm. Hy. 150. Ps. 18.

Easy Mrusic for Church Choirs. Part III., I 853 .

Set to the hymn 'Jesu Relemptor omnium.' 'The present arrangement is by the Rev. L. G. Hayne, and appears in the MIerton Tune Book, $\mathbf{1 8 6} 3$. It is there said to be an 'ancient 
melody,' but it has not yet been traced to an earlier source than the above.

St. Asaph. Ps. 146.

G. M. Gionnivichi.

Sacred Music . . . sung in St. George's Church, Edinburgh, edited by R. A. Smith, I 825 .

The tume has not been found in any earlier collection than the above. It is there assigned to Giornivichi, but the original has not been discovered among the works of that composer.

St. Audoën. Hy. 462.

R. P. Stewart.

Church Hymnal (authorised by the Irish Episcopal Church), I 874 .

Set to the present hymn.

St. Augustine. Hy. 315.

J. B. Calkin.

The Congregational Church Hymnal, I887.

Composed for the hymn 'Still will we trust, though earth seem dark and dreary.' Slight alterations were made by the composer to suit the present hymn.

St. Augustine. Ps. 158.

L. Mason and J. Goss.

The first part (major) is slightly altered from a tune by Dr. L. Mason called 'Lathrop' appearing in his New Carmina Sacra, I850. The second part (minor) was written by Sir John Goss for Mercer's Church Psalter and Hymn Book, I 854, where the tune is set to the two hymus 'The Church has waited long,' and ' $\mathrm{O}$ where shall rest be found.' In each of these certain verses are marked to be sung to the minor form of the tune.

St. Bartholomew. Ps. 95.

R. R. Cirope.

The Congregational Hymn and Tune Book, edited by the Rev. R. R. Chope, I 862.

Set to the hymn 'In stature grows the Heavenly Child.'

St. Beatrice. Hy. 499.

J. F. Bridge.

Hymns Ancient and Modern. Enlarged edition, 1875 .

Composed for this hymn.

St. Bees. Hy. 198.

J. B. Drkes.

The Congregational Hymn and Tune Book, edited by the Rev. R. R. Chope, I 862. 
Composed for the hymn 'Jesus, name of wondrous love.' Set to the present hymu in Hymns Ancient and Modern, enlarged edition, 1875 .

St. Benedict. $\mathrm{H}_{y}, 570$.

J. Stainer.

The Church Hymnary, i 898 .

Composed for this hymn.

St. Bernard. $\Pi_{y} .282$.

II. II. Monk.

Hynuns Ancient and Modern, I 86 I.

Set to two hymns 'O Jesu, Lord of light and grace,' and 'Jesu! the very thought is sweet.'

St. Bernard. Hy. 52, 97. P's. 96.

Neues... Kirchen und Hauss Gesang der . . Tochter Sion. . . Cölln, I 7łı.

The original of the present tune is set in the above collection to one of the hymns in praise of the Virgin Mary, the melocly being as follows:-
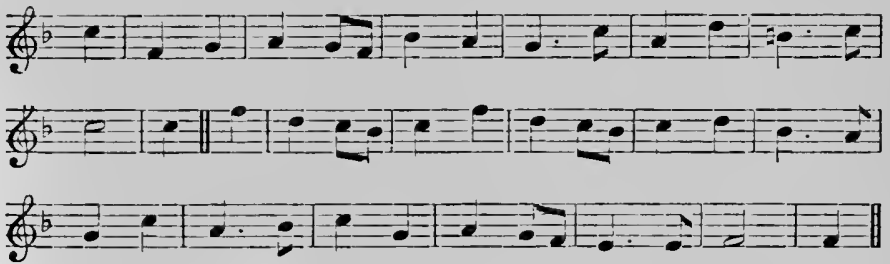

In a hymn book published in 1767 , entitled 'Heil- und IIiilfs-Mittel zum thiitigen Christenthum,' the meloly appears in the following form :-
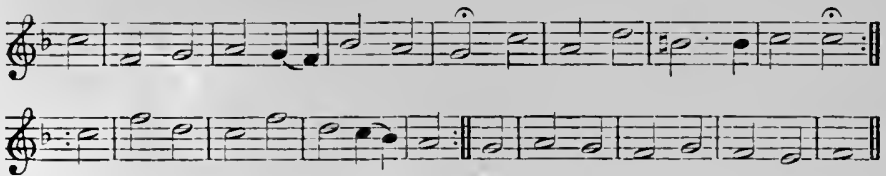

This is also found in Cantica Spiritualia, vol. ii., Munich, I 847. The present tume has probably been arranged from the last-named book, and seems to lave first appeared in Easy Hymn Tunes with the worls in full, arlapted for Catholic Schools, etc. This book has no date, but the British Museum 
Catalogue gives ${ }^{2} 8_{5} \mathrm{I}$. The tune is set to the hymn 'Jesus, the very thought of Thee,' and is headed 'Hymn of St. Bernard.' The adaptation was possibly made by J. Richardson, and the tune has been attributed to him in several collections.

St. Blane. Hy. 66 .

C. C. Scholefield.

Church Hymns with Tunes, I874.

Set to two metrical litanies.

Present name given in The Church Hymnary.

St. Bride. Hy. 186. Ps. 159.

S. Howard.

Parochial Harmony; consisting of a Collection of Psalm Tunes in three and four parts, etc., by William Riley, I 762.

Set to Psalm 130, New Version, and headed 'St. Bridget's Tune, by Mr. Saml. Howard.'

St. Cecilia. Hy. 110 . Ps. 170.

L. G. HAYNe.

The Merton Tune Book: A Collection of Hymn Tunes used in the Church of St. John Baptist, Oxford. Compiled by the Rer. H. W. Sargent, M.A. Edited and arranged by the Rev. L. G. Hayne. Oxford, i 863 .

Composed for the hymn 'Thy way, not mine, O Lord.'

St. Chrysostom. Hy. 213.

J. BARNBY.

The Hymnary, i 872.

Composed for this hymn. The tune was written for the above book, of which the composer was editor, but it was first printed in the Musical Times for December $187 \mathrm{I}$.

St. Clement. IIy. 371.

C. C. Scholefienu.

Church Hymns with Tunes, 1874 .

Composed for this hymn.

St. Columba. Hy. 361.

11. S. Irons.

Hymns Aneient and Modern, I86r.

Composed for this hymn.

St. Crispin. Hy. 249.

G. J. Elver.

A Selection of Psalm and Hymn Tunes, edited and arranged by E. H. Thorne. Enlarged edition, [1863].

Composed for the hymn 'Just as I am.' 
St. Cross. Hy. 58.

J. 1. DYKEs.

IIymns Ancient and Modern, I86I.

Composed for this hymn.

St. Cuthbert. IIy, 133, 633.

J. B. DYKES.

Hymns Ancient and Modern, I861.

Composed for this hymn.

St. Cyril. 11y. 525.

I. P. JiLiss.

The Charm: A Collection of Sunday School Mrusic. Cincinnati, I87I.

Composed for the present hymn, of which Mr. Bliss was also the author.

St. Cyril. I's. 97.

1. Patton.

Church Ifymmal (authorised by the Irish Episcopal Chureh), $187+$.

Set to the hymn ' $A$ pproach, my soul, the mercy-seat.'

St. David. IIy. 16, 636 . Ps. 98.

The Whole liooke of Palmes . . Composed into 4 parts by sundry $\Lambda$ uthors . . Newly corrected and enlarged by Tho. Ravenseroft, I62 I.

Set to Psalnis 43 and 95, the arrangement of the tune being by Ravenscroft himself. In the Index it is under the heading 'Welsh Tunes.' The melorly is as follows:-

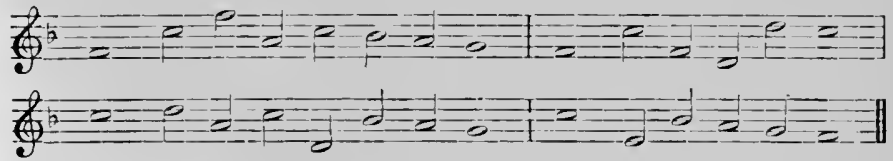

In John I'layford's P'salms and 11ymms, I6 $\mathrm{I}$, the tune appears exactly in the above form, but in his Whole Book of Psalms, 1677 , it is found in its present form.

St. Drostane. IIy. 47 .

J. 13. DYkes.

The Congregational Iymn and Tune Bork, edited by the Rev. R. R. Chope, I862.

Composel for this hymn.

St. Dunstan. Hy. 102.

li. ReIHEAD.

Church Hymn Tunes, Ancient and Modern, for the several 
seasons of the Christian Year ... selected, composed, and edited by Richard Redhead, I 853 .

Referred in the Index to the hymns 'Now the day's declining wheel,' and 'Holy Saviour ever blessed.'

St. Ebbe. Hy. 456.

R. Redifead.

Ancient Hymn Melodies and other Church Tunes, as used at All Saints' Church, Margaret Street. Arranged, Composed, and Harmonised by Richard Redhead, Organist, I 859 .

The tune is without a name, and is not referred to any hymn in particular.

St. Edmund. Hy. 303.

A. S. Sullivan.

The Hymnary, 1872.

Composed for this hymn.

St. Ethelreda. Hy. 228, 386. Ps. 99.

T. Turton.

Psalms and Hymns for Public Worship, with appropriate Tunes, edited by James Turle, i 863 .

The tune is dated in this book 1860 , but does not appear to have been published previously.

St. Ethelwald. Hy. 270.

W. H. MoNk.

Hymns Ancient and Modern, i86I.

Composed for this hymn.

St. Fergus. Hy. 455 .

J. W. Elliott.

Hymns Ancient and Modern. Enlarged edition, 1875.

Set to the 'Litany of the Holy Ghost.'

Present name given in The Church Hymnary.

St. Flavian. Hy. 14. Ps. 100.

The Whole Booke of Psalmes, collected into Encrlysh metre ... with apt notes to synge the withal . . Imprinted at London by John Day . . . I562.

The present is the first half, with slight alterations, of the tune of Psalm I32; the complete tune is as follows :-

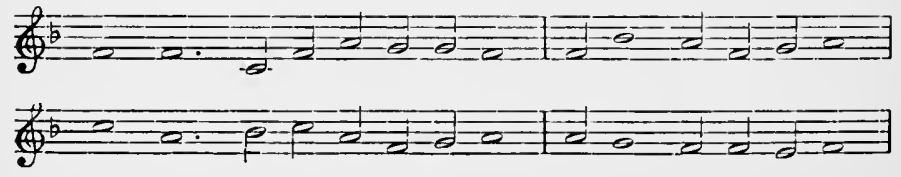



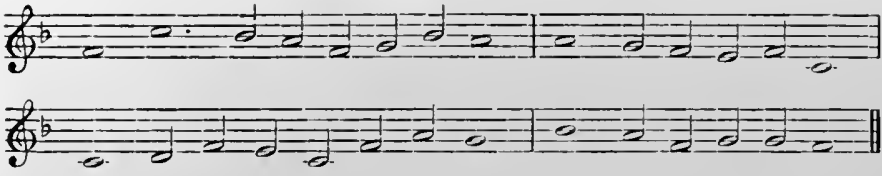

St. Frances. Hy. 53. Ps. 101.

G. A. Löır.

The Chorale Book, compiled by II. II. Bemrose and arranged by $\mathrm{Wr}$. Adlington, I86r.

Composed for the hymn 'Now that the daylight dies away.'

St. Francis. Hy. 401.

A. S. Sullivax.

Chureh Hymns with Tunes, I874.

Composed for this hymn.

St. Fulbert. Ir. 291. Ps. 102.

II. J. Cauntlett.

The Chureh Iymm and Tune Book, edited by W. J. lilew and II. J. Gauntlett, $185^{2}$.

Set to the hymn 'Now Christ, our Passover, is slain.' Original name of the tune is 'St. Leofred.'

St. George. Ps. 103.

N. Herman.

Ein Christlicher $A$ bentreien, vom Leben und ampt Johannis des Tauffers .... X. H., I 554 .

A tract of seven leaves, containing Herman's hymn 'Kommt her ihr liebsten Schwesterlein,' set to the melody as follows :-
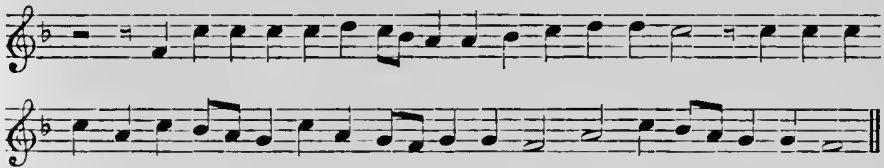

In his collection of hymns entitled 'Die Sontags Evangelia uber das gantze Jar, in 'iesenge verfasset,' issued in $\mathbf{5} \mathbf{5 6 0}$, Iferman set the tune to his hymu 'Lobt Gott, ihr Christen, alle gleich,' with which it has remained associated in Germany. The melody has undergone several modifications both in German and Einglish books.

St. George's, Edinburgh. Ps. 224.

A. MI. Thouson.

Sacred Harmony for the use of St. George's Church, Edinburgh, I 820 .

Composed for Psalm 24, vers. 7-10. 
St. George's, Windsor. Hy. 76, 494.

G. J. Elver.

A Selection of Psalm and Hymn Tunes, edited and arranged by E. H. Thorne. . . . Adapted to Psalms and Hymns compiled by the Rev. T. B. Morrell and the Rev. W. W. How, $185^{8}$.

Set to the hymn 'Hark, the song of Jubilee.'

St. Gertrude. Hy. 272.

A. S. Sullivan.

The Hymnary, 1872.

Composed for this hymn. The tune was written for the above book, but appeared first in the Musical Times for December 187 I.

St. Giles. Hy. 425.

J. M. BeLL.

The Scottish Hymnal, 1885 .

The tune is there set to the present hymn, but was not specially composed for it.

St. Godric. Hy. 467.

J. B. Dykes.

The Congregational Hymn and Tune Book, edited by the Rev. R. R. Chope, 1862.

Composed for the hymn 'Lord of the worlds above.'

St. Gregory. Hy. 518.

E. BunnetT.

Sacred Harmony, r865. A work containing Chants, Tunes, and Organ Pieces by Dr. Bunnett.

St. Gregory. Ps. 19.

Neuer Helicon mit seinen Neun Musen. Das ist, Geistliche Sitten-Lieder, etc., Nürnberg, I684.

The hymns in this book are by Christian Knorr, Baron von Rosenroth, and Zahn thinks that the melodies also may probably be his. The present is set to the hymn 'Zeuch meinen Geist, triff meine Sinnen,' as follows :-
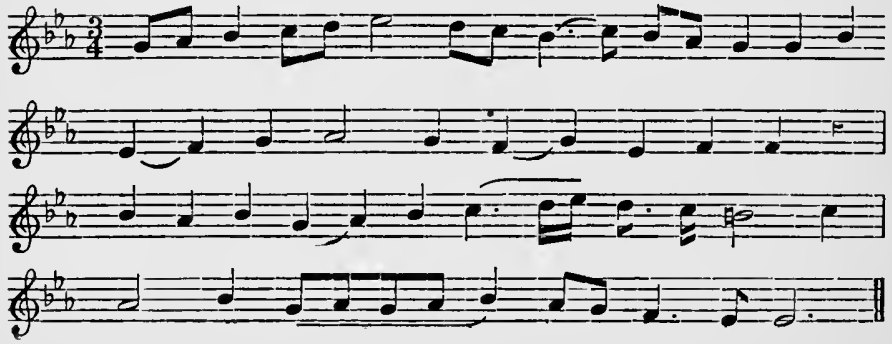
In later books the tune is altered and simplified. The present form is, with a slight alteration, that found in König's Choralbuch, 1738 .

St. Gregory. P's. 104.

R. WAINWRIGIT.

A Collection of Psalm Tunes internixed with Airs. . . set for four voices, for the use of ehoirs and families . . . and redieated to S. Weblbe, sen., by his son, S. Weble, jun., [1 808].

The tune also appeared in lipphonia, containing sixty-Two Psalm and Iymn Tunes. . . IIarmonised, Arranged, and Composed. ... By W. Dixon. This has no date, but must have been published between i 805 and I 808 .

St. Helen. Hy. 292.

W. HATELY.

The Scottish Hymnal, 1871 .

Composel for this hymn.

St. Helen's. IIy. 159.

R. P. STEWART.

Church Ifymial (authorised by the Irish Episcopal Chureh), 1874 .

Composel for this hymm.

St. Hugh. Hy. 283. I's. 10.).

E. J. Horkiss.

The Congregational Hymn and Tune Buok, edited by the liev. R. R. Cliupe, I862.

Set to the hymn 'There is a fountain filled with blood.'

St. Ignatius. $\mathrm{Hy}, 484$.

J. JiARxiy.

The Ilymnary, 1872 .

Composed for this hymn.

St. James. Hy. 127. Ps. 106.

R. Counthinhe.

Select l'salms and IIymus for the use of the I'arish C'hurch and Tabernacle of St. James's, Westminster, 1697.

St. Jerome. Hy. 173.

I. .J. GaveTtelet?.

The Church Ifymn and Tune Book, editerl by 11 . J. Blew and II. J. Gauntlett, 1852 .

Set to the hymn 'The day is past and gone.'

St. John. IIy. 632. I's. 175.

The Parish Choir, vul. iii., I8 8 I.

No information is given as to the source or composer of this 


\section{I32 THE MUSIC OF THE CHURCH HYMNARY}

tune, and it has not been traced to any earlier collection. The rhythm of the first line is slightly different from that now in use, being as follows:-

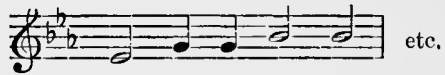

and the second and third last notes of the tune are minims instead of semibreves. The present form appeared in Congregational Church Music, 1853.

St. John Baptist. Hy. 279.

O. M. Feilden.

A Selection of Psalm and Hymn Tunes, edited and arranged by E. H. Thorne. Enlarged edition, [1863].

Set to the hymn 'Jesu, meek and gentle.'

St. John, Westminster. Hy. 410.

J. Turle.

Psalms and Hymns for Public Worship, with appropriate Tunes, edited by James Turle, I 863 .

Composed for this hymn.

St. Joseph. Hy. 573.

J. B. Calkin.

The New Mitre-Hymnal, adapted to the Services of the Church of England, with accompanying Tunes, 1875 .

Set to the hymn 'My God and Father, while I stray.'

St. Kerrian. Hy. 412.

The melody is quoted by Zahn from a Manuscript Book of Chorales, written at Dresden, г76г.

It is there set to the hymn ' $\mathrm{Da}$ Christus geboren war,' as follows:-

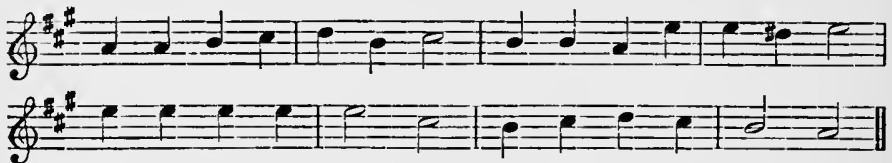

The present adaptation is by Sir John Stainer, and was published in the Hymnal Companion, third edition, 1890, set to this hymn.

St. Keverne. Hy. 216.

A. H. Brown.

The Bristol Tune Book. Supplement, I88r.

Composed for this hymn. 
St. Kilda. Ps. 107.

IV. R. Broomfield.

P'ublished on single slips about 1850 . The tune is carved on the monument erected over the composer's grave in Allanvale Cemetery, Aberdeen.

St. Lawrence. Hy. 450.

L. G. Hayne.

The Merton Tune Iook: $\Lambda$ Collection of Hymn Tunes nsed in the Chureh of St. John Baptist, Oxford. Compiled by the Rev. II. W. Sargent, M.A. Edited and arranged by the Rev. L. G. Hayne. Oxford, i863.

Set to the hymn 'Sun of my sonl.'

It is set to the present hymn in IIymus Ancient and MIodern, Appendix, 1868.

St. Lawrence. Ps. 108.

R. $\Lambda$. SHITII.

Devotional Mrusie Original and Selected, arranged mostly in Four parts, by R. A. Smith, [181o].

Set to the paraphrase 'Te hearens, send forth your song of praise,' and marked as 'composed for this work.'

St. Leonard. IIy. 108, 239, 491. Ps. $109 . \quad$ II. Sмart. I'salms and Ifymns for Iivine Worship, i 867.

St. Lucy. IIy. 523.

II. J. Poole.

Twenty-two Original IIymn Tunes, by Two Oxford Ciraduates, Oxford, 1867 .

Composed for the hymn 'Oft in sorrow, oft in woe.' The names of the composers are not given in the above collection, but MIr. I'oole's tunes are distinguished by the initial 'J.'

St. Mabyn. Iy. 187.

A. II. Brown.

Composed in 1868 to the hymm 'Warth has many a noble city.'

Appeared in the Bristol Tune book, Seconl series, 1876 , but may have been printed previous to that date.

St. Magnus. IIy. 88. I's. 110.

J. Clatik.

The Divine Companion: or, 1)aril's ILarp New Tun't. Being a Choice Collection of New and Lasy Psalms, IIymns, and Anthems . . . The Thirl elition, r 709 .

Set to Dr. Patrick's version of Psalm II7, 'Let all the nations of the world.' 
No composer's name is attached to the tune, though the three tunes which immediately precede it are said to be 'by Mr. Jer. Clark.' In W. Riley's Parochial Harmony, i 762, it bears its present name and is ascribed to Clark. It is called 'Nottingham' in Gawthorn's Harmonia Perfecta, I73o.

St. Margaret. Hy. 207.

A. L. Peace.

The Scottish Hymnal, I885.

Composed for this hymn.

St. Margaret. Hy. 59.

IV. Statham.

Hymns Ancient and Molern. Enlarged edition, I875.

Composed for this hymn.

St. Martin. Hy. 558.

C. Steggali.

Hymns for the Church of England with Proper Tunes. Second edition, 1875 .

Composed for the hymn ' $O$ let him whose sorrow.'

St. Mary. Hy. 182. Ps. 111.

Llyfr y Psalman, wedi en cyfieithu, a'i cyfansoddi ar fesur eerdil, yn gymraeg, I62 I.

The Welsh Metrical Translation of the Psalms by Arehdeacon Prys.

Set to Psalm 2.

The second line reals thus-

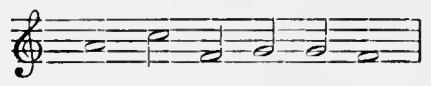

There is no I flat in the signature, so that the tune is apparently in the Dorian mode, the $\mathrm{B}$ in the first line remaining natural. $A$ s, however, the music printing in the volume is very faulty it is possible the omission of the flat may be aceidental. The tune is found in its present form in Playford's Book of Psalms, i677.

St. Mary Magdalene. Нy. 263.

J. B. DYKes. The Congregational Ifymm and Tune Book, edited by the Rev. R. R. Chope, 1862.

Composed for this hymn. 
St. Matthew. Hy. 43, 512. Ps. 147.

IV. Croft.

A Supplement to the New Version of Psalms by Dr. Brady and Mr. Tate... The Sixth Edition, corrected and much enlarged ... r 708 .

The tune bears its present name, and is marked in the Index as a new tune. It is set to Psalm 33, in two parts, treble and bass, as follows :-
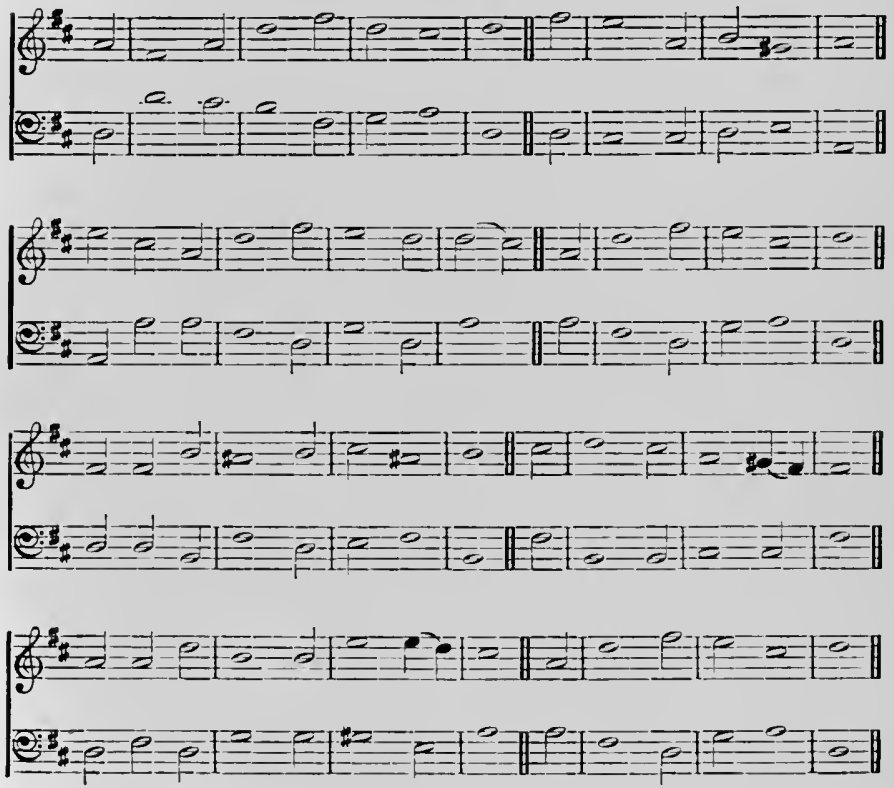

The above publication contains no composers' names, but it is generally believed that Dr. Croft was concerned in its production, and that 'St. Natthew' is his composition. From the middle of the eighteenth century his name is invariably attached to it in all the collections in which composers' names are found.

St. Matthias. IIy. 618.

W. II. Mosk.

IIymns Ancient and Modern, I86r.

Composed for this hymn. 
St. Matthias. Ps. 112.

O. GibBons.

The Hymnes and Songs of the Church, by G. Wither, I623.

This book contains a number of tunes in two parts by Orlando Gibbons. The present is set to Song 67 for St. Matthias Day, beginning ' When one among the Twelve there was.'

The present tune is unchanged from the original.

St. Medan. Hy. 149.

Har. by Wr. H. Monk.

Hymns Ancient and Modern. Enlarged edition, I 875.

Set to the 'Litany of the Passion.'

Present name given in The Church Hymnary.

St. Mildred. Hy. 378.

C. Steggall.

Church Psalmody, edited by Charles Steggall, 1849.

St. Mirren. Ps. 113.

R. A. Smiti.

Sacred Music . . . sung in St. George's Church, Edinburgh, edited by R. A. Smith, 1825 .

St. Neot. Ps. 114.

Under the name 'Worksop,' this tune is found in many collections of the eighteenth century. Probably the earliest to include it are those published by John and James Green. No trace can be found of the first two editions of Green's book, but the title of the third is given by the Rev. Henry Parr, as follows: 'A Collection of Choice Psalm Tunes in Three and Four parts; with New and Easie Psalm Tunes, Hymns, and Spiritual Songs . . . Third edition, I 7 I 5.'

In this and the subsequent editions of Cireen's collection, the nelody of 'Worksop' is as follows :-
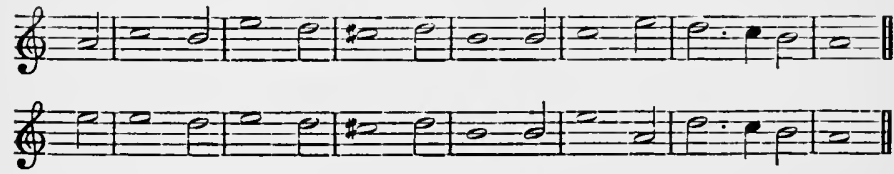

St. Nicholas. Ps. 115.

The Spiritual Man's Companion: or, The Pious Christian's Recreation ... The Fifth edition, with large Additions, never before printed, by Israel Holdroyd, Philo-Musicæ, I753. 
Set to Psalm 119, second part, and healed 'St. Nicholas's Tune.' No composer's name. The melody is as follows:-
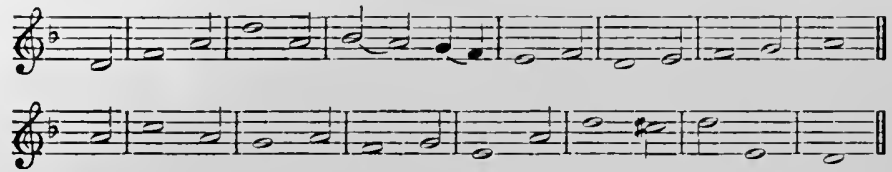

In Riley's Parochial MIusic Corrected, $\mathbf{1 7 6 2}$, it stands as follows :-
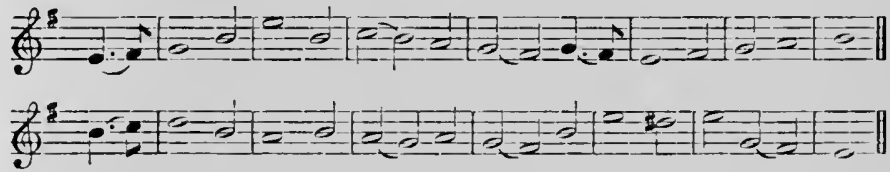

Later books exhibit various slight differences in the form of the melody, especially in the close of line $\mathrm{I}$ and in line 4 . The present form probably first appeared in the Sentish Psalmody, 1854, where it is said to be 'arranged by Herr Diurmer.'

St. Nicolas. IIy. 107.

R. REDHEAD.

Church IIymn Tunes for the several seasons of the Christian Year. Second scries, [1859].

Referred to the hymn 'Lo, the gollen light is peering.'

St. Ninian. IIy, 5.

Zionsharfe, Ein Choralschatz . . von Dr. Conrad Kocher. Vierte Abtheilung, enthalteml die schünsten Melodicen der katholischen Kirche, 1855 .

Set to the hymm 'Kommst du, Jesu, Licht der IIeiden.' The melouly lias not been traced to any earlier source.

St. Olave. IIy. 327, 473 . I's. $160 . \quad$ I1. J. (inuntlett. The Church IIymn and Tnue Iimk, elited by W. .J. Hhew and II. J. Gituntlett, I 852 .

Set to the hymn 'Delight and joy of earth.' Originally named 'St. George.'

St. Oswald. Iy. 459.

J. J. I)YKes.

A Manual of P'salm and IIymu Tunes used in the Parish Church of St. Michael, Houghton-le-Spring, edited by the IIon. and Rev. J. Grey, i 857. 
Set to the hymn 'Praise the Lord! ye heavens, adore Him,' and named 'St. Bernard.' In Hymns Ancient and Modern, I875, the tune is named 'St. Oswald,' and is set to the present hymn.

St. Palladius. Hy. 177.

J. BARnBy.

The Home and School Hymnal, 1892.

Composed for this hymn.

St. Patrick. Hy. 84 .

A. S. Sullivan.

Church Hymns with Tunes, 1874 .

Composed for this hymn.

St. Paul. Hy. 294. Ps. 116.

So far as has yet been ascertained the earliest book containing this tune is a small collection printed by James Chalmers in Aberdeen in I749. The only copy at present known wants the title-page, but the date is ascertained from the names of the provost and bailies of Aberdeen, to whom the work is dedicated.

The tune bears its present name, and is in two parts, tenor and bass, as follows:-
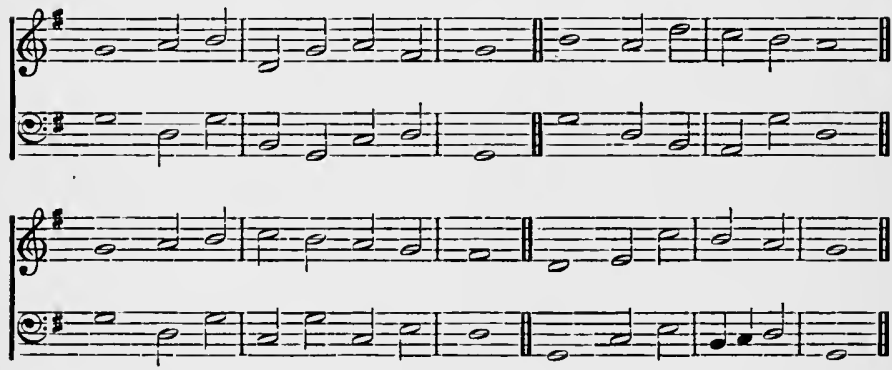

The $\Lambda$, fourth note of line 2 in the bass, is a misprint for $\mathrm{C}$, and is duly noted in the preface as a 'fault of the engraver.'

The tune is included in Bremner's collection issued in Edinburgh in ${ }^{1756}$, under the name 'Aberdeen or St. Paul.'

St. Paul's. Hy. 614.

J. Stainer.

Iymus Ancient and Modern. Enlarged edition, 1875 .

Composed for the hymn 'Lord Jesus, think on me.' 
St. Peter. Hy. 201. Ps. 117.

Psalm Tunes for the Voice and Pianoforte, ly $\Lambda$. R. Reinagle, 1830.

Set to Psalm I 8.

St. Peter's, Westminster. IIy. 106. J. TurLe.

Psalms and Hymns for Public Worship, with appropriate Tunes, edited by James Turle, $186_{3}$.

Composed for this hymn.

St. Petersburg. IIy. 234.

I). Bortsianski.

The original of this melody is in a Mass composed by Bortnianski in 1822 . It is found as a hymn tune in a collection entitlel 'Choralbuch, Enthaltend die Melodien zu der Sammlung . . . von Johannes Gossner, Leipzig, 1825.' In this book, which was editel by I. II. Tscherlitzky, an organist in St. Petersburg, the tune is set to the hymn 'Ieh bete an die Macht der Liebe,' as follows :-
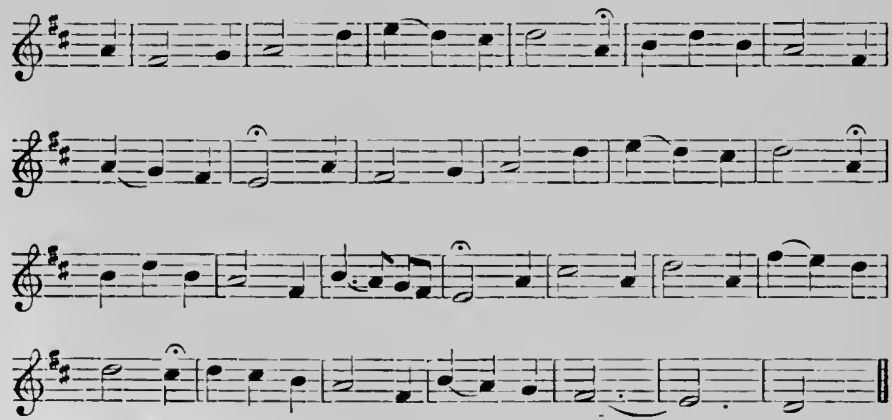

The tune appears as the 'Prayer' or slow movement in the (irosse Zapfenstreich (Grand Tattoo), a kind of serenade which, at the cluse of the annual manourres of the Cerman army, is played by the combined bands of the regiments.

St. Philip. IIy. 339.

J. liarsit.

The Sarum I ymnal, with proper Tunes. The II sic edited by T. E. Aylward, i 869 .

Composed for this hymn. 
St. Philip. Hy. 138, 183.

W. H. MIonk.

Hymns Ancient and Modern, i86r.

Composed for the hymn 'Lord, in this Thy mercy's day' (No. 183 ).

St. Polycarp. Hy. 394.

Sacred Melodies . . . adapted to the best English Poets . . . by William Gardiner, vol. ii., I 8 I5.

The melody, headed 'Subject from Pleyel,' is as follows :-
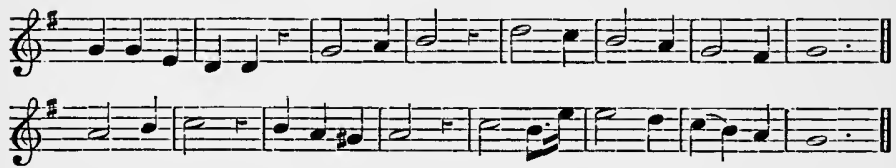

The words being 'Father of mercies, God of love, Send Thy pardon from above,' etc.

St. Raphael. Hy. 262.

E. J. Ногкікs.

The Congregational IIymn and Tune Book, edited by the Rev. R. R. Chope, I862.

Composed for the hymn ' Jesu, Lord, we kneel before Thee.' Named 'St. Giles' in the above book; 'St. Raphael' in the composer's Temple Church Choral Service, 1867.

St. Saviour. Hy. 489.

F. G. BAKER.

The Bristol Tune Book. Second series, 1876 .

St. Sebald. Hy. 556.

C. H. Dretzel.

Evangelisches Choral-Buch . . . herausgegeben von Cornelio IIeinrich Dretzeln, Niurnberg, I 731.

Set to the hymn 'Meine Hoffinung stehet feste.'

'The present form of the melody is the same as the original. Harmonised by Sir John Stainer for The Chureh 11ymary.

St. Sepulchre. Hy. 426. Ps. 20.

G. Coorer.

The Congregational Hymn and Tune Book, edited by the Rev. R. R. Chope, I862.

Set to the hymn 'Lord Jesu! when we stand afar.'

St. Stephen. Ps. 118.

I. SMITII.

A Collection of Psalm Tunes in Three Parts . . . by Isaac Smith, [circa 1770 . 
The original name of the tune is ' $\Lambda$ bridge,' by which it eontinues to be known in England.

In Sacred Harmony for the use of St. George's Church, Edinbursh, i 820, it appears under the name 'St. Stephen's,' and with the following form of the last line--

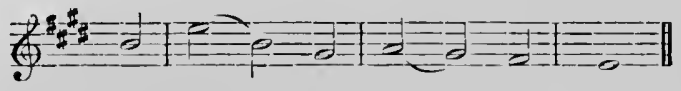

This was adopted in some later books published in Sectland, but the present form is in aceordance with the original.

St. Sylvester. IIy. 31\%.

J. I. DYKES.

The Congregational Hymn and Tune Book, edited by the Rev. R. R. Chope, 1862.

Composed for this hymn.

St. Theodulph. IIy. 49, Аppx. 15.

MI. Tesciner.

Ein antkiehtiges Gebet . . . so wol ein tröstlieher Gesang, darinnen ein frommes IIerz dieser Welt Valet gibet, etc. Leipzig, 1615 .

$\Lambda$ small tract of six leaves containing the hymn by Herberger, 'Talet will ieh dir geben,' and two melorlies set to it by Melehior Teschner. Isoth are arranged for five voices. The present is the secoml of the two, and is as follows:-
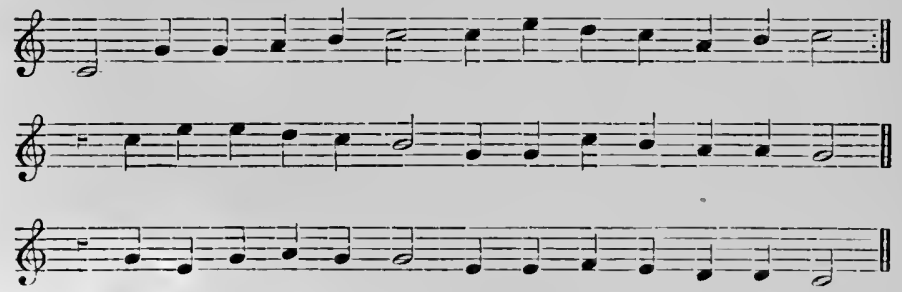

Later German books exhibit various slight elanges in the nelody. The substitution of $\mathrm{C}$ for $\mathrm{A}$ at the eleventh note is found in the Gotha Cantional, 1648.

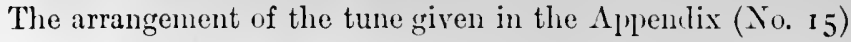
is that used at Nerton College, Oxforl.

St. Thomas. Ps. 119.

A Collection of Tunes... suited to the several MIetres 
commonly used in Publick Worship, set in Four Parts . . . by C. Ashworth, [circa I 760$]$.

Called 'Walney 'Tune,' the melody as follows :-
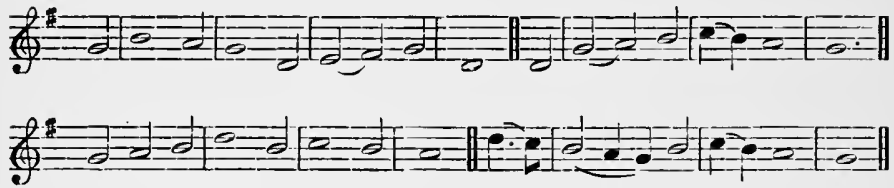

It appears in its present form and with the present name in Moore's Psalm Singer's Delightful Pocket Companion, Glasgow, 1762 .

St. Victor. Hy. 436, 597.

R. Redhead.

Ancient Hymn Melodies and other Church Tunes, as used at All Saints' Church, Margaret Street. Arranged, Composed, and Harmonised by Richard Redhead, Organist, I 859 .

St. Werbergh. Hy. 190.

R. P. Stewart.

Church Hymnal (authorised by the Irish Episcopal Church), I 874 .

Composed for this hymn.

Saints of God. Hy. 38.

A. S. Sullivan.

Church Hymns with Tunes, I 874 .

Composed for the hymn 'The saints of God, their conflict past.'

Salamis. Hy. 534.

In 1841, Mrs. Luke, the author of this hymn, visited the Normal Infant School in Gray's Inn Road. She says: 'Among the marching pieces at Gray's Inn Road was a Greek air, the pathos of which took my fancy, and I searched Watts and Jane Taylor, and several Sunday school books, for words to suit the measure; but in vain. Having been recalled home, I went one day on some missionary business to the little town of Wellington, five miles from Taunton, in a stage-coach. It was a beautiful spring morning, it was an hour's ride, and there was no other inside passenger. On the back of an old envelope I wrote in pencil the first two of the verses now so well known, in order to teach the tune to the village school.' The hymn so written and the 
tune referred to, have remained associated, but nothing further seems to be known of the origin of the latter. They were printed in the Sunday School Teacher's Magazine, at the end of the volume for $184 \mathrm{I}$.

Sales. Hy. 148.

F. H. Cinamereys.

Hymns Ancient and Modern. Enlarged edition, 1875 .

Composed for this hyms.

Salisbury. Ps. 120.

The Whole Booke of Psalmes. . . Composed into 4 parts by sundry Authors. . . . Newly corrected and enlarged by Tho. Ravenseroft, 1621 .

Set to Psalms 17 and 54, named 'Salisbury Tune,' and classed in the Index anong English Tunes. The melody is exactly as at present.

Salzburg. Ps. 121.

J. M. HAYDN.

Adapted from a morement in a Mass composed 'for the use of country choirs.' The movement is printed in the Rev. C. I. Latrobe's Selection of Saered Music. It is in 6-8 time, beginning thus-

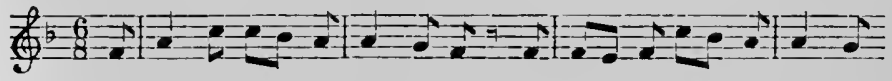

Samuel. Hy. 606.

A. S. Sullivax.

Church Hymns with Tunes, 1874.

Composed for the present hymm.

The original arrangement is for treble voices in unison with organ aceompaniment. The present four-part arrangement was made by the composer for The Presbyterian Hymmal, I 877 .

Sanctuary. Hy. 336, 433.

J. 1). DYKFs.

The Anglican Hymn Jook, 1871.

Composed for this hymm ( $\mathrm{T}$ o. 336).

Sandon. Hy. 297.

C. HI. PURday.

The Chureh and Home Metrieal Psalter and Ily'mnal, erliterl by Charles H. Purday, 1860.

Composed for this hymn.

In the above the tune is anonymous, but in a later edition, I862, Mr. Purlay's name is attached to it. 
Sandown. Hy. 599.

J. BaRnBy.

The Hymnal Companion to the Book of Common Prayer. Third edition, I 890 .

Composed for the hymn 'Do no sinful action.'

The tune is set to the present hymn in The Home and School Hymnal, 1892, of which the composer was musical editor.

Sandringham. Hy. 175.

F. A. J. Hervey.

The Church Hymnary, i 898 .

Composed for this hymn.

Saxony. Hy. 121. Ps. 21.

Christlichs Gesangbüchlein, etc. . . . Mit einer Vorrede M. Cyria. Spangenberg . . Eisleben, I 568.

Set to the hymn 'Christ, der du bist der helle Tag,' as follows :-
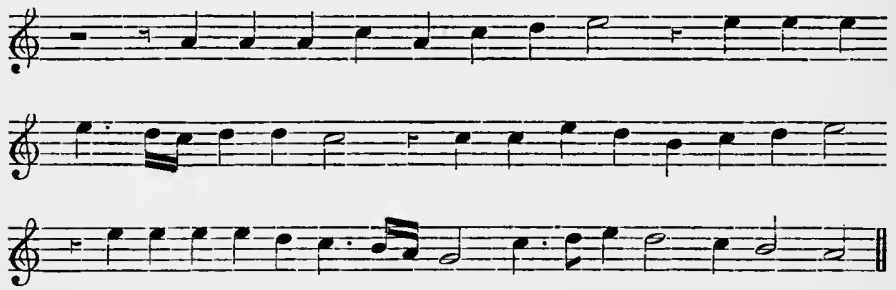

Later German collections exhibit many variants in the melody. The present arrangement was probably first published by the Rev. W. H. Havergal in his Old Church Psalmody, I 847 .

Schönberg. Hy. 478.

J. Hintze.

Praxis Pietatis Melica. . . Editio xix., 1678.

Set to the hymn 'Alle Menschen muissen sterben.' The tune is here anonymous, but it appears in the twenty-fourth edition (1690) of the above work, with the initials J. H., which are known to stand for Jacob Hintze.

The tune has been frequently attributed to J. Rosenmiiller. This mistake secms to have arisen from the fact that the above hymn, 'Alle Menschen,' etc., was written for the funeral of a 
Leipzig merchant in $\mathbf{1 6 5 2}$, and was printed with music by Rosenmuiller. This music, however, is totally different from the present tune.

Scopas. Hy. 542.

C. Haxcock.

The Congregational Psalmist, edited by Dr. Henry Allon. Second Appendix, 1875 .

Composed for this hymn.

Sebaste. Hy. 355 . J. Stainer. Hymns Ancient and Modern. Enlarged extition, 1875. ? 1868 Composed for this hymn.

Second Advent. Hy. 112.

A. L. Peace.

The Church of England IIymnal, 1895.

Composed for this hymn.

The refrain was slightly alterel by the composer.

Sefton. Hy. 610.

II. A. Crosbie.

The Burnley Tune Book, 1875 .

Composed for the hymn 'Saviour, breathe an evening blessing.'

Selma. Ps. 161.

R. A. SMitir.

Sacred Music . . . sung in St. George's Church, Edinburgh, edited by R. A. Smith, 1825 .

Set to Psalm 67, and described as an 'Ancient Scottish Melody. Noted in the Island of Arran, and harmonised by Mr. Smith.'

Sepulchre. Hy. 72.

E. H. Thorne.

A Selection of Psalin and IIymn Tunes, edited and arranged by E. II. Thorne. Enlarged edition, [1863].

Composed for this hymn.

Serenity. Ps. 162.

C. Bryax.

A Collection of the most esteemed Psalm Tunes, Ancient and Modern, Selected and Harmoniserl for Four Toices, and interspersed with a few original Compositions, edited by Cornelius Bryan, [circa i83o].

Set to Psalm 25, ver. 8 (Tate and Brady version). 
Sheffield. Ps. 122.

W. MATHER.

Dr. Watts's Psalms and Hymns, set to new music . . . eomposed by Edward Miller . . . to which is added a copious Appendix containing the most favourite tunes now used in different congregations, I 802 .

The present tune is in the Appendix. It is named ' $A$ ttereliffe,' and is set to the hymn 'Begin the high celestial strain.' In the Index it is marked as a 'new tune, never beforc printed.'

Shoreham. Hy. 359.

J. B. DYkes.

Congregational Church Musie. Enlarged edition, I87 r.

Composed for the hymn 'My God and Father, while I stray.'

Simplicity. Hy. 554.

J. S'TAINER.

The Chureh Hymnary, i 898.

Composed for this hymn.

Slingsby. Hy. 289.

J. B. Drkes.

The Supplemental Hymn and Tune Book, compiled by the Rev. R. Brown[-Borthwiek], I867.

Composed for this hymn.

Smart. Hy. 241.

H. SMART.

The Hymnary, 1872.

Composed for this hymn.

Soldau. Hy. 140. Ps. 22.

Geystliche gesangk Buchleyn. Wittenberg, I524. Edited by Johann Walther.

Set to the hymn by Luther, 'Nun bitten wir den heiligen Geist,' as follows :-
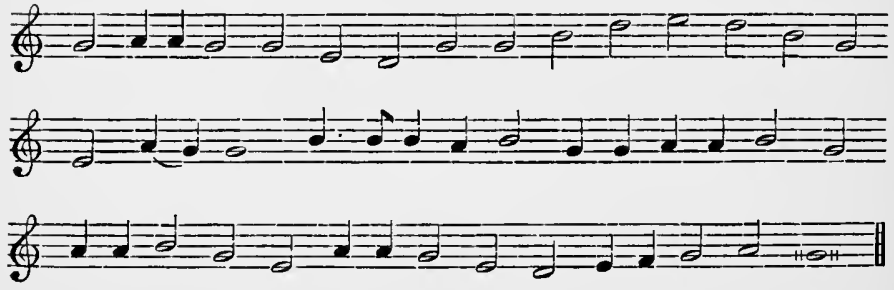
The melody may be from a pre-Refurmation source, and adapted by Walther.

The present form of the tune appeared in Dibdin's Standard Psalm Tune Book, I 85 I.

Sonning. Hy. 350.

II. J. Gauntiett.

The Congregational Psalmist, editerl by Dr. IIenry Allon and II. J. Gauntlett, i 858 .

Sons of Labour. Iy. 260.

J. Stainer.

IIymns Ancient and Modern. Supplement, I 889.

Composed for this liymn.

Southwark. Hy. 169. Ps. 123.

C. Tye.

The Aetes of the Apostles, translated into Englyshe Meter . . . by Christopher Tye, 1553. (See under ' Gethsemane.')

The first half of the tune set to chap. viii. thus-

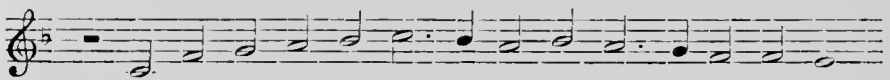

The death of Steven rlid Saule eom-fort who did a-gre with them

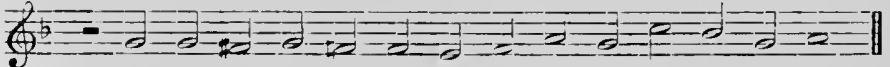

That wold have slayne the god - lye sort Then at Je - ru - sa - lem.

Southwell. 11y. 329. Ps. 124.

II. S. Iross.

Hymns Aneient and Morlern, 186r.

Composed for this liymn.

Southwold. Ps. 125.

I. J. GaunthetT.

The Church Ilymn and Tune liook, edited by W. J. Blew and H. J. Gauntlett, 1852 .

Set to the hymn 'Now that the daylight dies away,' and ealled 'Southwell Tune.' The name is changed to 'Southwold' in the Congregational Psalmist, 1859, enlited by Dr. H. Allon and Dr. Crauntlett.

Spohr. IIy. 391, Appx. 12. Ps. 126.

L. Sporrls.

Calvary (Des Heilands letzte Stunden): In Oratorio by Louis Spohr. First performed at Cassel on Good Friday, $18_{35}$.

The present tune is an adaptation from the solo and ehorus 'Though all thy friends forsake thee.' 
Springfield. Hy. 36.

H. J. Gauntlett.

The Comprehensive Tune Book, edited by H. J. Gauntlett, 1846-5 I.

The tune is there named 'Stowell,' and is in 7777 metre, as follows :-
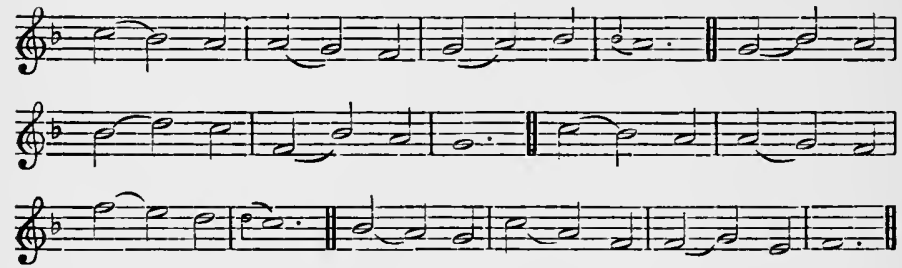

The present form of the tune appeared, without composer's name, in Maurice's Choral Harmony, 1854 .

Springtide Hour. Hy. 595.

J. Barngy.

The Methodist Sunday School Tune Book, 188r.

Composed for the hymn 'The springtide hour brings leaf and flower.'

Set to the present hymn in The Home and School Hymnal, 1892, of which the composer was musical editor.

Springtime. Hy. 490.

Arr. by A. S. Sullivan.

Chureh Hymns with Tunes, 1874 .

Arranged for this hymn from a chant attributed to Dr. Aldrich.

Stabat Mater. Hy. 61.

J. B. DYKES.

Hymns Ancient and Modern. Enlarged edition, 1875 .

Composed for this hymn. Written in $187 \mathrm{I}$ for the ehoir of St. John's Church, Leeds.

Stand up for Jesus. Hy. 267.

J. Barnat.

Hymns Ancient and Modern. Supplement, 1889.

Composed for this hymn.

Star of Peace. Hy. 615.

L. MASON.

The National Psalmist, edited by Lowell Mason and G. J. Webb. Boston, Mass., I 848 .

Composed for this hymn. 
Steggall. Hy. 549.

C. Steggali.

Hymns for the Church of England with Proper Tunes, edited by Charles Steggall, $186_{5}$.

Composed for the hymn 'God that madest earth and heaven.'

Stella. Hy. 618.

Lasy Ilymn Tunes with the words in full, alapted for Catholic Sehools, etc., [1851?].

Set to the hymn 'Hail, Queen of Heaven, the ocean star.' No composer's name or source is given. The tune is probably alapted from an old English popular melody.

Stephanos. Hy. 159.

II. W. IBAKER.

Hymns Ancient and Modern. Appendix, 1868.

Composed for this hymn. The harmony is by Dr. W. H. Monk.

Stettin. Hy. 184.

N. Decius.

(ieistliche Lieder auffs new gebessert und gemehrt... Leyptzick, I 539 .

Set to the hymn 'Allein Gott in der IHöh' sei Ehr,' the version by Nicolaus Decius of the 'Gloria in excelsis,' as follows:-
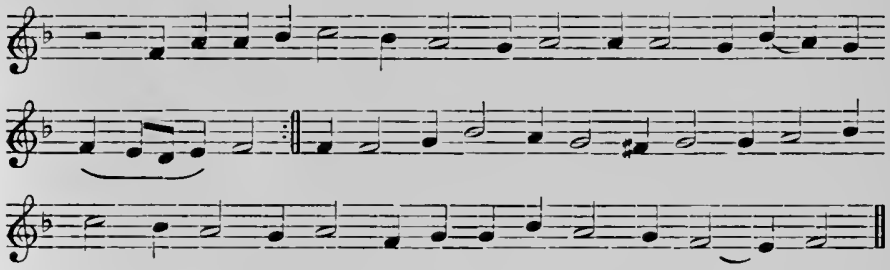

The melody is probably an adaptation from a pre-Reformation source.

The present form of the tune is that used by Mendelssohn in 'St. Paul.'

Sto ad Ostium. Hy. 161.

(i. C. Martix.

The Chureh Hymnary, r 898.

Composed for this hymn.

Stobel. Hy. 197.

Old Church Psalmorly, erlited by the Rev. W. H. Havergal, Appendix to 5th edition, I860. 
Stated to be 'from J. D. Muiller's Choral Buch, I 754.' That book, however, contains no tune at all resembling this, nor has it been discovered in any other German collection.

Stockton. Hy. 421 . Ps. 127.

T. WRIGHT.

This tune was used in the church of Stockton, where the composer was organist from 1797 to 1818 . It was subsequently used in Wakefield Parish Church, but remained in MIS. till r861, when it was printed in Hymns Ancient and Modern, the arrangement there being by Dr. Dykes. In the original the last line is

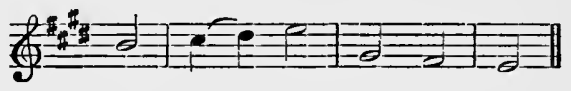

Stroudwater. Ps. 128.

A Book of Psalmody, containing some easy instructions for young beginners; to which is added a select number of Psalmtunes, Hymns and Anthems. Collected, Printed, Taught, and Sold by Matthew Wilkins of Great Milton near Thame in Oxfordshire, [circa 1730 .

The present tume is set to Psalm 146, and is headed 'Stroudwater New Tune.'

Stuttgart. Hy. 607.

Psalmodia sacra, oder, Andächtige und schöne Gesänge . . . Gotha, I7 5 .

Set to the hymn 'Sollt es gleich bisweilen scheinen,' as follows :-
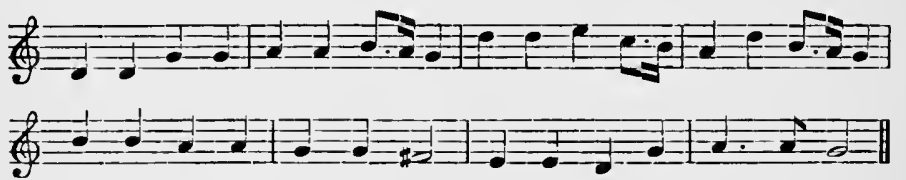

Sunninghill. Hy. 480 .

G. J. ELVEY.

The Congregational Church Hymnal, 1887.

Composed for the hymn ' $O$ throned, $O$ crowned with all renown.'

Suppliant. Hy. 317.

Myles B. Foster.

The Congregational Church Hymnal, 1887.

Composed for this hymn. 
Swabia. Hy. 229. Ps. I63.

Davids Harpffen Spiel, In hundert und funffzig Psalmen, Auch dreyhundert zwey und vierzig Lieder Melodien ... Aufgesetzt von Johann Martin Spiess . . Heydelberg, 1745.

Set to the hymn 'Ach wachet! wachet auf!' as follows:--
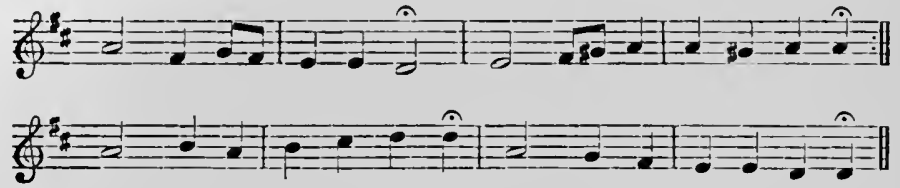

The present arrangement of the melody is by the Rer. W. H. Havergal, and appears in his Old Church Psalmody, i 847 .

Sweet Hosannas. Hy. 546.

Alapted from Handel.

From the chorus 'From the east unto the west' in 'Solomon.'

The present arrangement was probably made by T. Clark of Canterbury. It appeared set to this hymn in the Bible Class IIagazine, July i 851, headed 'The Children's Hosanna, arlapted from Handel.' It was ineluded in the enlarged edition of 'The Juvenile Harmonist, published the following year.

Tabor. Hy. 588.

C. Steggall.

Psalms and Hymns for Divine Worship, I867.

Set to this hymn.

Tadcaster. Hy. 457 .

E. J. Hopkiss.

The Temple Church Choral Service, edited by Eitwarl J. Ifopkins. Supplement, 1877 .

Composed for the hymn ' Forward be our watchword.'

Tallis. Hy. 510. P's. 129.

T. Tallis.

The whole Psalter translated into Finglish Metre, ete., [by Matthew Parker]. (See under 'Evening IIymn.')

This is the last of the nine tunes by Tallis printed at the end of the book. It is set to the metrical version of the hymm 'Veni Creator Spiritus,' begimingr 'Come, Holy Ghost, eternall God.'

In this instance the melody is in the highest part or 'Meane,' instead of in the Tenor. 
Temple. Hy. 354.

E. J. Hopkins.

The Temple Church Choral Service, edited by Edward John Hopkins, 1867 .

Composed for this hymn.

Tenbury. Hy. 180.

J. Stainer.

The Church Hymnary, 1898 .

Composed for this hymn.

Tenderness. Hy. 549.

R. W. BEAT'Y.

The late Major G. A. Crawford stated that this tune was composed by Beaty about the year 1830 for the children of Lady Harberton's School, Dublin. It has not been ascertained whether it was published at that time, nor for what hymn it was written. It is set to the present hymn in the Rev. C. H. Bateman's Sacred Melodies for Children, I843. In Psalmodia Britannica, a collection of psalms, etc., by Edwin Flood, vol. ii., 1854, it appears as 'arranged by Eberhard Siehl,' and is set to a poem beginning ' When the spark of life is waning, Weep not for me.'

Ter Sanctus. Hy. 4. Battison Haynes.

The Church Hymnary, I898.

Composed for this hymn.

Tetworth. Hy. 242.

G. M. GARRETT.

The Church of England Hymnal, 1895.

Composed for this hymn.

Thanksgiving. Hy. 87, 582 .

W. B. GILbert. Songs of Praise and Tcn other Hymns set to Music by Walter B. Gilbert, [1862].

Composed for the hymn 'Come, ye thankful people, come.'

The Blessed Home. Hy. 330.

J. Stainer.

Hymns Ancient and Modern. Enlarged edition, 1875.

Composed for this hymn.

The Blessed Rest. Hy. 320. J. Barniby.

The Home and School Hymnal, I892.

Composed for this hymn. 
Theodora. Hy. 129.

A. LEGGE.

The Congregational Psalmist, edited by Dr. Henry Allon. Second Appendix, 1875 .

Written some time previously for the use of the choir of the Parish Church, Ashford, where the composer is organist.

Composed for this hymu.

Tichfield. Hy. 447, 623.

J. Richardson.

Collection of Catholic Hymns for the use of Choirs and Congregations, edited by the Rev. If. Formby and J. Lambert, I 853 .

The tune has no name, but Richardson is given as the composer. It is set to a hymn headed 'Litany of the Passion of Jesus,' beginning 'By the blood that flowed from Thee.'

Tiverton. Ps. 130.

- Grigg.

$\Lambda$ Selection of Psalm and Iymm Tunes, from the best authors, in three and four parts: adipted principally to I)r. Watts's Hymus and Psalms, and to Dr. Rippon's Selection of Hymns, by John Rippon, D.I)., [circa 1795].

The composer's name is given as above, without any Christian name.

Totland. Hy. 248. J. STAINER.

The Church Hymnary, I 898.

Composed for this hymm.

Tours. Hy. 536.

I3. Tours.

The Hymnary, 1872 .

Set to the present hymn, and also to 'For thee, $O$ dear, dear country.' It is uncertain for which of these the tune was composed.

Trinity. Hy. 1.

S. S. WESLEY.

$A$ Selection of Psalms and Iymns arranged for the Public Service of the Church of England, edited by the Rev. Charles Kemble and S. S. Wesley, i864.

Composed for this hymn.

Triumph. Hy. 93, 466, 630.

H. J. Gauxtlett.

The Church Hymn and Tune Book, edited by W. J. Blew and II. J. Gauntlett, $18 \mathbf{5}^{2}$.

Set to the hymm 'Sing the glorious body broken,' and named 
'Tune of the Blessed Sacrament.' The present name is attached to it in Dr. Allon's Congregational Psalmist, 1858, of which Dr. Gauntlett was musical editor.

True-hearted. Hy. 257.

J. Воотн.

The Congregational Mission Hymnal, 1890.

Composed for this hymn.

Truro. $\mathrm{Hy}$. 435.

Psalmodia Evangelica : $\Lambda$ Collection of Psalms and Hymns in Three Parts for Public Worship, by Thos. Williams, 2 vols., 1790. Set to the hymn 'Now to the Lord a noble song.' The tune has been assigned to Dr. Burney, but there seems to be no evidence in support of this. It is without composer's name in the above collection, while several tunes by Burney have his name duly attached to them.

Trust. Hy. 501.

J. B. DYкеS.

The Hymnal, with Tunes Old and New, New York, I874. Edited by the Rev. J. Ireland Tucker, Troy.

Composed for the hymn 'Rock of Ages,' and originally named 'Faith.' The present form of the last line is by the composer's son, Mr. J. St. O. Dykes, and was substituted for the original at the request of Dr. Dykes's representatives.

Ulpha. Hy. 444.

E. Moss.

The London Tune Book, a Companion to all Hymnals now in use, [1877]. Edited by Edwin Moss.

Set to this hymn.

University College. IIy. 275.

H. J. Gaunthett.

The Church Hymm and Tune Book, edited by W. J. Blew and II. J. Gauntlett, 1852 .

Set to the hymn 'Since the heavenly Lamb hath stood.'

Urswicke. IIy. 195.

G. J. ELveY.

The Children's Hymn Book, edited by Mrs. Carey Brock, 1881.

Composed for the hymn 'In God's holy dwelling.'

Uxbridge. Ps. 131.

The Standard Psalm Tune Book . . . Arranged for 4 voices with an organ accompaniment by IEenry Edward Dibelin . . . I $8_{5}$ I. 
In this work the tune is headed 'Ascribed to Purcell,' but no confirmation can be found for this statement, nor has the tune been discovered in any earlier collection.

Valediction. Ify. 503. J. IT. Einfoter.

The Church IIymnary, i 898 .

Composed for this hymn.

Valete. $\mathrm{Hy} .508$.

A. S. Sullivax:

Church Hymns with Times, 1874.

Composed for the hymn "Sweet Silviour, bless us ere we go.'

Vaughan. $1 \mathrm{yy} .163$.

J. J. ILorkixs.

The Temple Chureh Choral Service Book, edited hy Edward J. Ilopkins, r 880 .

Comprosed for this hymn.

Veni cito. IIy. 119.

J. 1). Drkes.

Hymus Ancient and Modern. Enlarged edition, 1875 .

Composed for this hymn.

\section{Veni Creator. 1Iy. 136.}

This melody has been associated with the hymm 'Veni Creator Spiritus' ever since that hymn eame into use in the services of the Church, not later than the tenth century. The first of the two forms here given is that adopted in 1Fymus Ancient and Modern. It liffers to some extent from that found in the pre-Reformation 'Hymnale Sarum,' which is as follows:-
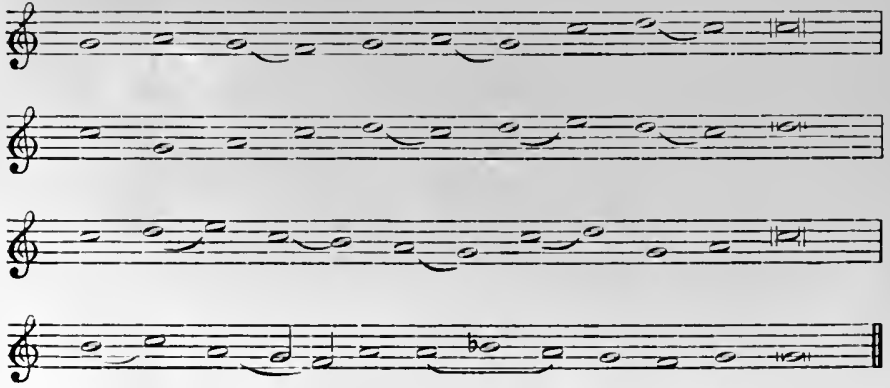
The second or Lutheran form is that adopted in nearly all the German Protestant hymn books. It is found in Geistliche Lieder, Wittemberg, I535, set to Luther's translation of the Latin hymn.

Veni Domine Jesu. Hy. 535.

J. Barnby.

The Congregational Mission Hymnal, r89o.

Composed for this hymm.

Veni Immanuel. $\mathrm{Hy} .109$.

IIymnal Noted. Part II., I 856.

In that book this melody is said to be 'From a French Missal in the National Library, Lisbon.' These Missals have all been examined by the Rev. W. Hilton of the English College, Lisbon, but this melody is not to be found in them. In all probability it is not a genuine mediæval melody, but has been made up of a number of plain-song phrases, most of these being found in settings of the Kyrie. The tune in its present form cannot be traced to an earlier source than the Hymnal Noted, and the likelihood is therefore that the adaptation was made for that book to suit Dr. Neale's translation.

Veni Spiritus. Hy. 146.

J. Stainer.

The Church Hymnary, i 898 .

Composed for this hymn.

Venit Hora. Hy. 55.

J. Stainer.

The Chureh Hymnary, 1898 .

Composed for this hymm.

Vesalius. Hy. 475.

E. C. Perry.

The Chureh of Fingland IIymnal, 1895.

Composed for the hymn 'Praise ye Jehovah.'

Vespers. Hy. 361.

R. P. Stewart.

Church Hymnal (authorised by the Irish Episeopal Church), I 874 .

Composed for this hymn.

Vexillum. Hy. 571.

H. Syart.

Hymns Ancient and Modern. Appendix, 1868.

Composed for this hymn. 
Via Crucis. Hy. 285.

J. IIARYBY.

The Hymnary, I 872.

Composed for this hymn.

Victory. Hy. 322.

J. IBARTBY.

A Hymnal, chiefly from The Book of Praise by Sir Roundell Palmer. Set to music, selected, harmoniser, and comprosed by John Hullah, I 868.

Composed for this hymn.

Victory. Hy. 78.

Alapted from Palestiusa.

In adaptation from the 'Ciloria l'atri' of the 'Magnificat Tertii Toni,' contained in the work entitled 'Magnificat Octo Tonorum,' published by Palestrina in I 591 .

The present arrangement was male by I)r. Wr. H. Mouk for this hymn, anrl appeared in IImms Ancient and Modern, I 861 .

Vigilate. IIy. 264.

W. II. Mosk.

Hymns Ancient ant Modern. Appendix, 1868.

Composed for this hymn.

Vox Dilecti. Hy. 172.

J. I, DYkes.

Ilymns Ancient and Modern. Appendix, 1868.

Composed for this hymn.

Vox Domini. Hy. 172.

J. BARNBY.

Unpublished Hymn Tunes by Joseph liarnby, 1896 .

Composed for the hymn 'Te that have spent the silent night.'

The form of the first bar in original is-

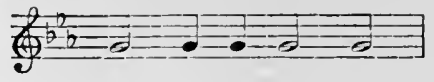

Wainwright. Iy. 233.

R. WAINWRight.

A Collection of Hymms, with appropriate Symphonies and Accompaniments, as originally composed for the Children of the Liverpool Blue Coat IIospital, (circa 1790).

Set to the hymn 'My God, and is Thy table spread,' and 
named 'Newmarket.' The original form of the tune is as follows :-
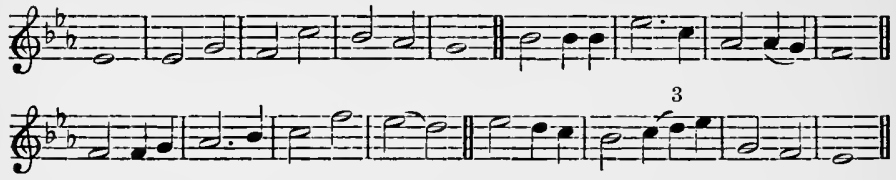

Waldeck. Ps. 132.

J. H. KNeCIIT.

Vollständige Sammlung . . Choralmelodien . . Herausgegeben von Christmann und Knecht, Stuttgart, I799.

Set to the hymn 'Du, Gott, bist uiber alles Herr.'

Waldrons. Hy. 199.

C. E. Miller.

The Hymnal Companion to the Book of Common Prayer. Third edition, 1890 .

The tune was composed in $187 \mathrm{I}$ and sung in the same year in St. Peter's Church, Croydon, to the hymn 'Approach, my soul, the mercy-seat.'

Mr. Miller states that this was the first tune written by him.

Walton. Hy. 70. Ps. 23.

Sacrel Melodies from Haydn, Mozart, and Beethoven, adapted to the best Finglish Poets, and appropriated to the use of the British Church, by William Gardiner, vol. ii., I8I 5 .

The melody is headed 'Subject from Becthoven,' but the original has not been discovered in any of that composer's works. In his Music and Friends, 1838 , Gardiner gives some information as to the sources of his Sacred Melodies, and states regarding the present that it 'is somewhere in the works of Beethoven, but where I cannot now point out.'

Wareham. Hy. 408, 481. Ps. 24.

W. Kंnapp.

$\Lambda$ Sett of New Psalm Tunes and Anthems, in Four Parts, . . . by William Knapp, 1738 .

Set to Psalm 36, vers. 5-10, new version, 'But, Lord, Thy mercy my sure hope,' and headed 'For the Holy Sacrament.' 
The melody is as follows:-

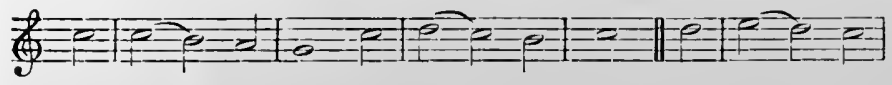

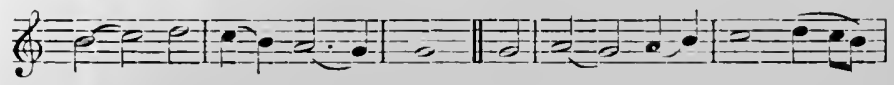

$7 \bar{y}=0$

In another publication entitled New Chureh Melody . . . by William Knapp, 1754 , the tune appears as under in common time, set to Psalm I 39, and called 'Plandford Tune.'

t)

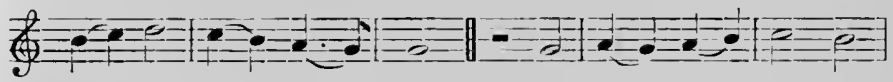

toe

Warfare. $\quad \mathrm{II} .563$.

I. J. Hutton.

Twenty IIymns for Children. Set to music by Laura J. Intton. Printed for private circulation, I88o.

Composed for this hymn.

Warrington. Hy. 438. Ps. 25.

R. HARRTíon.

Sacred IIarmony; or, A Collection of P'salm Tumes, Ancient and Molem. ... The whole set in Four Parts. . . My R. Harrison, wrl. i., [ 1784$]$.

This tur. is set in key D, the melody being as follows:-

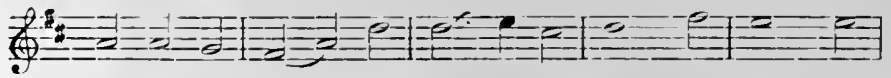

$780=$

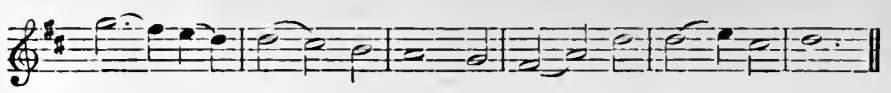


Waterstock. Hy. 156.

J. Goss.

Parochial Psalmody: A Collection of Ancient and Modern Tunes. . . The whole arranged with an accompaniment for the Organ or Pianoforte by John Goss, organist of Chelsea New Church, 1826.

Set to Psalm 136 'To God, the mighty Lord.'

The present form of the melody contains some slight variations from the original, which is as follows :-
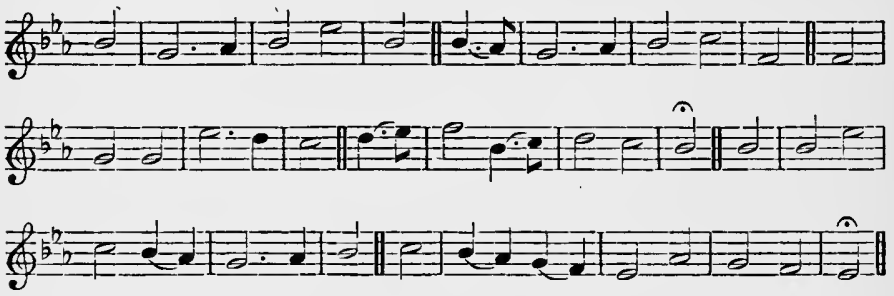

Wellesley. Hy. 486.

G. J. Elvey.

The Children's Hymn Book, edited by Mrs. Carey Brock, I 88I. Composed for the hymn ' $O$ Jesus, I have promised.

Westenhanger. Hy. 288.

C. W. Poole.

The Congregational Psalmist, edited by Dr. Henry Allon, Part III., I86I.

Westminster. Hy. 24 . Ps. 133.

J. Turle.

The Psalmist: A Collection of Psalm and Hymn Tunes . . . edited by Vincent Novello, Part II., I 836.

Named 'Birmingham' in this collection, which was issued in four parts, each containing a hundred tunes, at intervals between 1835 and I 844 .

Westmoreland. Hy. 75 .

C. Steggall.

Psalms and Hymns for Divine Worship, 1867.

Composed for this hymn.

Wetherby. Ps. 134.

S. S. WESLEY.

The European Psalmist: A Collection of Hymn Tunes; . . . the whole revised ... and much of the new portion composed by Samuel Sebastian Wesley, Mus. Doc., 1872.

Set to the hymn 'Awake, ye saints, and raise your eyes.' 
Weybridge. Hy. 616 .

IV. II. Saxgster.

Hymms Ancient and Modern. Appendix, i $\$ 68$.

Composed for this hymn.

When He Cometh. Hy. 585.

G. F. Root.

Our Song Birls, r 866.

Composed for this hymm.

When the Weary. Iy. 393.

(r. J. EILEY.

The Home and School Hymmal, 1892.

Composel for this hymn.

Wigton. P's 13\%.

The Psalmes of l havil, in Prose and Meeter: with their whole Tunes, etr., Edinburgh, 1635 .

This edition of the Scottish Book of Common Oriter contains thirty-one Common 'Tunes, the present being No. I6. (See umler 'Caithness.')

In the original the first line stands thus--

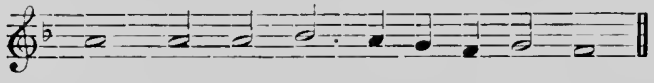

Wildersmouth. IIy. 578 .

E. J. Mopliss.

The Temple Church Choral Service, edited by Eilward J. IIopkins. Supplement, i 877 .

Set to the hymns 'O'er the realms of pagan darkness' and 'Angels from the realms of glory.'

Wilton. Iy. 126 .

A. H. MANA.

The Chureh Hymnary, 1898 .

Composed for this hymn.

Wiltshire. 1 y. 284. Ps. 136.

G. T. Syart.

I)ivine Amusement, Being a Selection of the most admired Psalms, Iymms, and Inthems used at St. James's Chapel. . . . The whole Composed and Compiled ly George Thomas Smart, organist of St. James's Chapel . . [ [rirca 1795$]$.

Set as under to Psalm 48 -

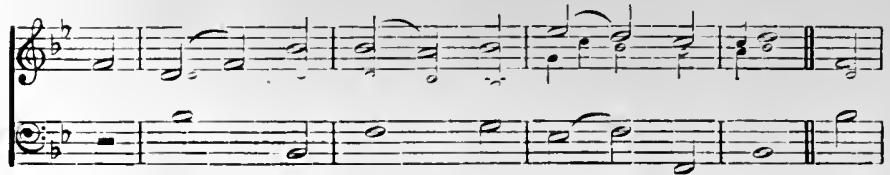



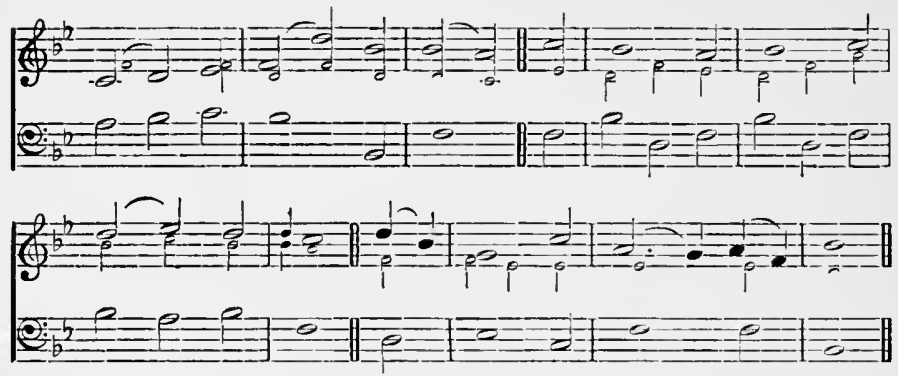

The bass is figured, and at the begimning of the volume there is the following note: "For the accommodation of those who lo not understand thorough Bass, it is explained in Small Totes, which may be Played or Omitted at Pleasure.' From this it will be seen that at the beginning of the second line the small notes of accompanying harmony have now been adopted as the melody, while the original notes of the melody have been transferred to the alto part. Apparently this ehange was allowed and approved by the composer, for he adopted it when he included the tume in his Collection of Sacred Music, published in 1863; and he gave his express sanction to the present form of the tune when published in Church Melodies, elited by Dr. Henderson, I'aisley, in 1856 . Other forms of the tune have appeared in different eollections.

Wimbledon. Hy. 290.

S. S. WESLEY.

$A$ Selection of Psalms and Hymns arrangel for the Public Services of the Church of England, edited by the Rer. Charles Kemble and S. S. Wesley, 1864.

Composed for this hymn, and dated 1863.

Winchester. Hy. 134, 439. Ps. 137.

The Whole Booke of Psalmes with their wonted Tunes, as they are song in churches, composed into foure parts... Compiled by sondry authors. London, Thomas Est, I 592.

Set to Psalm 84, the name of G. Kirby being attached to it, meaning that the arrangement is by lim. In the editions of this book issued in 1594, 1604, and I6I I the tune does not appear, Psalm 84 being set to the tune known as 'Old Common 
Tune'; but in Ravenscroft, 1621 , P'layford, 1671 and 1677 , that Psalm is again set to 'Winchester.' The name of the tune appears first in Ravenscroft.

The tune seems to be partly alapterl from the second half of melody set to chap. viii. in C. Tye's Aetes of the Apustles, which is as follows:

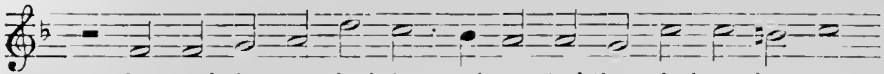

Scat-tred they were both far and uye, And through the regions crept

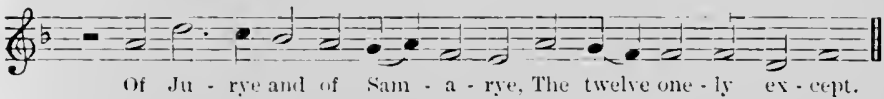

The secoml last note is shown by the harmony to be a misprint for $\mathrm{k}$. The first half of this melocly is the tmue 'Sonthwark' (\%r.).

Winscott. My. 25:), 343.

S. S. MESLEY.

The European I'salmist: I Collection of $]$ ymm Tunes . . . The whole revised . . and much of the new portion enmposed by Sammel Sebastian Wesley, Mus. Doe., I 872.

Composed for the hymu 's'm of my soul.'

Wirksworth. P's. 164.

i lionk of l'salmorly containing Variety of Tunes for all the Common Metres of the Psalms in the ()d, and New Versions, and others for I'articular Measures . . all set in Four Parts, within such a compass as will most naturally suit the voices in Country Clunrehes, yet may be sung in Three or Two without any lisallowinces. Hy John Chetham, 1718.

The tunes are not named, aml no composers are griven. The present tmue is set to I'siln 50 , as follows:-

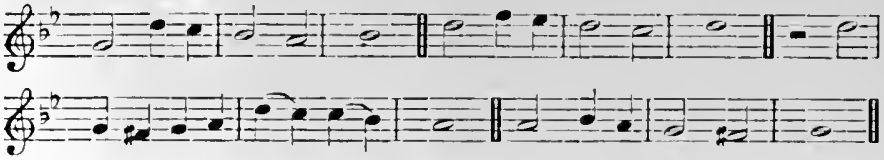

In the third edition, 1724, of the same book, the last line is altered to

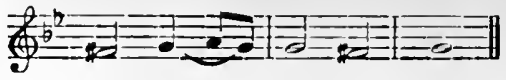


The present form of the tune is found in A Book of Psalm Tunes with variety of Anthems in Four Parts . . . By James Green. Fifth edition, I 724 .

Woodbrook. Hy. 557 .

J. ADcock.

The School Hymnal Tune Book, edited by J. Adcock, 1887.

Set to the hymn 'Jesus, tender Saviour.'

Wordsworth. IIy. 470.

WT. H. Monk.

The Holy Year, by Charles Wordsworth, D.I., with appropriate Tunes, edited by W. H. Monk, $186_{5}$.

Composed for the hymn ' $\mathrm{O}$ day of rest and gladness.'

York. Hy. 513. Ps. 138.

The CL. Psalmes of David, in Prose and Meeter : with their whole usuall Tunes, etc., Edinburgh, I6 5 .

One of the 'xii. Common Tunes' found in this edition of the Scottish Book of Common Order. (See under 'Abbey.')

The name of the tune there and in all old Scottish books is 'The Stilt.' Its earliest appearance in England is in Ravenscroft's Whole Booke of Psalmes, 1621 , where it is classed as a 'Northerne Tune,' and named 'Yorke.' In this work it is found with three different harmonies, two of these being by John Milton, the father of the poet. This has given rise to the mistake committed by many later compilers, who have assumed that the harmoniser was also the composer of the melody.

Zion. Hy. Appx. 10.

IV. AscoCk.

The Church Hymnary, 1898.

Composed for the hymn ' Little travellers Zionward.'

Zoan. Hy. 440.

IV. H. Havergai.

$\Lambda$ Hundred Psalm and Hymn Tunes by Wr. H. Havergal, I 859 .

Set to the liymn 'From Greenland's icy mountains.' 


\section{CHANTS}

Note.-In regard to many Chants it is difficult to state with certainty in what book they were first printed. It must be understood therefore that in many eases the date of the collection cited is not to be taken as that of the comjosition or earliest use of the Chant. Many of them were donbtless in nse at an earlier period, and would he found in the mannscript, or frivately printed, collections belonging to the various Catherlials and Churches.

Aldrich in F. Ps. 189.

II. Aldiricir.

1 Collection of Tunes and Chants for Public Worship, compiled by the Rer. Wm. IIarrison. . . . The arrangement by Mr. Jno. Hopkins, i 848 .

The above is the earliest collection in which the chant has been found. There and in more recent collections it is attributed to Dr. Allrich, hut it is doubtful whether it is really by him. It does not appear in any of the older eollections whieh contain his chants.

Ayrton in E flat. $\mathrm{Iy}: 6+2$.

E. Arrtos.

Divine IIarmony, Being a Collection of Two IIundred and Seven Double and Single Chants in Score, Ancient and Modern. Sung at His Majesty's Chapels Royal. London, Feby. 1770. Engraved and Published by Thos. Tandernan.

Battishill in A. Ps. 17\%.

J. Battisinil.

Fifty Double and single Chants being the must farorite as perfor'm'd at St. I'aul's, W' estminster, and most of the Cathedrals in England, [circa 1768 ].

Also in Vandernan's Collection (see above).

Beckwith in D. Ps. 190.

J. C. Вескінitu.

The First Yerse of every Psalm of David, with an Ancient or Modern Chant in Seore, 1808. 
Chants-continued.

Beethoven in C minor. Ps. 191.

Arr. by J. Goss.

Parochial Psalmody, Part II., editer by John Goss, 1838 .

Arranged from the Allegretto of Beethoven's 7 th Symphony.

Blow in $\mathbf{E}$ minor. Ps. 178.

J. Blow.

An Introduction to the Skill of Musick, by John Playford. Serenth edition, 1674 .

At the end of this edition is 'The Order of performing the Divine Service in Catliedrals and Collegiate Chapels,' and the present chant is given as one of six 'sung in His Majesties Chappel with the organ to the Psalms, Te Deum, ete.'

Boyce in D. Hy. 644. Ps. 192.

IV. Borce.

Divine Harmony, Being a Collection of Two Hundred and Seven Double and Single Chants in Score, Ancient and Modern. Sung at His Majesty's Chapels Royal. London, Feby. I770. Engraved and Published by Thos. Vandernan.

The chant is there assigned to 'Mr. Davis.' In the Rev. R. Harrison's Sacred Harmony, rol. i., $\mathbf{z} 784$, it appears as a short metre tune, and in rol. ii., I79r, as a chant. In both cases Dr. Boyce is named as the composer, but as Vandernan was a Gentleman of the Chapel Royal, and published his collection while Ir. Boyce was organist there, it is quite probable that he is correet as to the composer of the ehant.

Bullinger in E flat. Hy. 562 .

E. W. Bullixger.

There is some dubiety as to the history of this chant. It appeared, set to the present hymn, in The Children's Hymn Book, 188I ; the editor of that book having received it direct from Dr. Bullinger. The latter writes, on 3 Ist August I900, 'I certainly composed the metrical chant you refer to some years ago.' It appeared, however, in The Bristol Tune Book, I863, where it is assigned to ' $\mathrm{Ir}$. Reynolks,' and set to the hymn 'My God and Father, while I stray.'

Camidge in $\mathbf{E}$ minor. Ps. 193.

M. CAMidge.

Chants, Ancient and Modern, in score, edited by John Goss, I 84 I. 
Cirasts-continned.

Cooke in C minor. Ps. 194.

R. Cooke.

Chants, Ancient and Morlern, in score, ellited by John Goss, I $S_{+1}$.

Cooke in G. P's. 195.

R. Cooke.

Chants, Ancient and Molern, in score, edited by John Goss, I $S_{+}$I.

Cooper in G. Ps. 196.

J. T. Cooper.

The Chant-Book Supplement to the II ymual Companion to the Buok of Cummon Prayer. Cimpiled and arranged under the exlitorship of Jusph Thomas Conper, 1871 .

Croft in A minor. Ps. 179.

II. Croft.

Cathmiral Mnsic, being a collection in score of the most valuable ant useful compsitions for that Service ly the sereral English Masters of the last two humber rears. The whole selected aml carefully revisel hy Ih. William buree, vol. i., i 760.

Crotch in C. P's. 197.

IV. Croteri.

A Selection of Single and Double Chants . . eollecterl and arrangerl by John Clarke (afterwardi Clarke-Whitfelil), Mus. Lhe., Cambrilge, [rirea is so].

Crotch in G. P's. 19R.

IV. Croteir.

Cithedral Chants, edited hy Alfrel liennett and William Marshall, 1829 .

Crotch in G. I's. 199.

IV. Croter.

Cathedrul Chants, elited by Alfred Iennett and William Marshall, i 829.

Crotch in A. 1's. 200.

IV. Croteri.

Catheilal Chants, elited by Alfred Bennett and William Marshall, i 829.

Dupuis in A. Ps. 201.

T. S. Dupuis.

Cathelral Music . . by 1)r. William linyce (see above, umler 'Croft'), vol. ii, 1768.

Farrant in F. I's. 180 .

R. Farrant.

Adipted from the anthem 'Ioril, for Thy tender mercies' sale.' 
Chants-continued.

Felton in E flat. Ps. 181.

IV. Felton.

Sacred Harmony; or, A Collection of Psalm Tunes... Together with a Selection of Chants, etc. By R. Harrison, vol. ii., [1791].

Flintoft in G minor. Ps. 202.

L. Flintoft.

Fifty Double and Single Chants being the most favorite as perform'd at St. Paul's, Westminster, and most of the Cathedrals in England, [circa I768].

Also in Vandernan's Collection, I770. The chant may be an adaptation from a tune in Playford's Psalms, 167I. (See ante under the tune 'Playford.')

Gibbons in G. Hy. 644 .

C. Gibbons.

Fifty Double and Single Chants, [circa 1768] (as above).

In this collection the chant is headed 'by Mr. Preston,' but in Vandernan's Collection, I770, it is assigned to C. Gibbons.

Goodenough in G. Ps. 203.

R. P. GoodexougiI.

A Collection of Chants as used at Christ Chureh Cathectral and St. John's College Chapel, Oxford ... By W. Cross, Organist of Christ Chureh Cathedral, [circa I810].

Goss in E flat. Hy. 641.

J. Goss.

Chants, Ancient and Modern, in scorc, edited by John Goss, I $84 \mathrm{I}$.

Handel in G. Ps. 204.

Alapted by W. KNyveTr.

Cathedral Chants, edited by Alfred Bennett and William Marshall, i 829.

Adapted from the duet 'Joys in gentle trains appearing' in the oratorio 'Athaliah.'

Havergal in A. Ps. 205.

IV. H. Havergal.

A Hundred Double Antiphonal Chants, with Remarks on Chant and Chanting, by W. H. Havergal, 1836 .

Hopkins in $\mathbf{E}$ flat. Ps. 182.

E. J. Hopkins. The Anglican Chant Book ... edited by Edwin George Monk. Second edition revised, 1853 . 


\section{Chants-contimued.}

Hopkins in C. Ps. 206.

E. J. Норкiss.

The Temple Church Choral Service, edited by Edward Joln Hopkins, I 867.

Hopkins in G. P's. 207.

E. J. Hopkiss.

Chants as used in Westminster Abber, edited by James Turle, [1 1857 .

Hopkins in G minor. P's. 208.

E. J. Hopkiss.

The Temple Church Choral Service, edited by Edward John Hopkins, 1867 .

Humfrey in C. P's. $1 \leqslant 3$.

P. HLMFrey.

Cathedral Murie ... by 1)r. William lingee (see above, under 'Croft'), vol. i., i 760.

Set to the 'Tenite.'

Kelway in D. Hy, 644.

T. KFLWAY.

Chants as need in Westminster Abber, edited by James Turle, $[1857]$.

Langdon in F. P's. 209.

R. Lasgnos.

Divine Ifarmony: being a Collection in Seore of P'ralnins and Anthems, composed by the mont eminent manters . . . relected and . . . revised by R. Langilon, I $\mathbf{\jmath}+$.

The chant is anonymous, but has always been ascribed to Laingion.

Lawes in C. I's, 210.

II. LAwes.

Chants, Ancient and Modern, in seore, edited by John Goss, $18+1$.

Headed 'Artanged from Lawes,' but the original has not been traced.

Lee in F. $11 y, 642$.

W. ILE.

Fifty Duble and single Chants being the most favorite as perform'd at st. Paul's, Westminster, and must of the Cathedrals in England, [circa 1768 ].

Macfarren in C. Ps. 185, 186.

G. A. Macfarrex.

The Angliean Chant liook ... edited by Elwin George Monk, 1850. 
Chants-continued.

Morley in D minor. Ps. 211.

TI. MorLEY.

Cathedral Music .. by Dr. William Boyce (see above, under 'Croft'), vol. ii., I 768 .

Mornington in E flat. Ps. 212.

Earl of Morisgton.

This chant in its present form and also the one following are in Cross's Colleetion, circa i 8ı. (See under '(roodenough.') This may have been their first appearance in print, though they have been in continuous use in the 1)ublin Catherlrals since the time of the composer. The original form of this chant, still usect in Dublin, is-
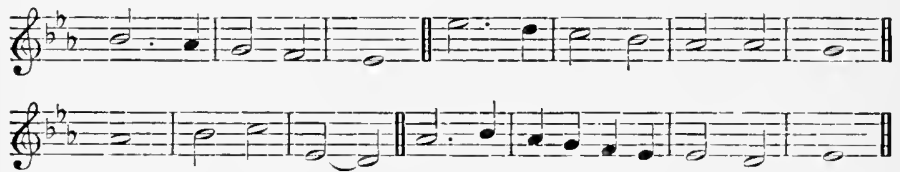

Mornington in E flat. Ps. 213.

Earl of Mornington.

See above. This chant is also inelucted in A Selection of Single and Double Chants . . . collected and arranged by John Clarke (afterwards Clarke-Whitfelı), Mus. Doc., Cambrilge, [cirea isio].

Norris in A. Ps. 214.

T. Norris.

A Selection of Single and Double Chants.. . by John Clarke (afterwards Clarke-Whitfeld), [cirea i8 8 o].

The chant is also included in Cross's Collection. (Siee abore under 'Goodenongh.') It is meertain which of these collections was the earlier in date.

Ouseley in D. Hy. 643 .

F. A. G. Ouseley.

The Psalter with the Canticles and Hymns of the Church. Pointed for chanting and set to appropriate chants. Ellited by the Rev. Sir F. A. Core Ouseley and F. F. Monk, [1862].

Ouseley in D. Hy. 641 .

F. A. G. Ouseley.

The Psalter, etc. (as above).

Ouseley in G. Iy. 644 .

F. A. G. Ouseley.

The Anglican Chant Book . . . elited by Edwin George Monk. Second edition revised, I 853 . 
Chaxts-continued.

Patten in $\mathbf{E}$ flat. II. $6+0$.

W. I'Attex.

Cathedral Chants, edited by Alfred Bennett and William Marshall, i 829.

Pring in G. I's. 215.

.) PRIsici.

Cathedral Cliants, edited by Alfred Fennett and William Marshall, 1829 .

Randall in D. Iy. $6+4$.

J. RANDALL.

I Selection of Single and Double Chants... hy John Clarke (afterwarls: Clarke-Whitfeld), [cirea r 8 Io].

The chant is also ineluled in Cross's Cullection. (see above muler '(iookenomgh.') It is uneertain which of these colleretions was the arlier in date.

Robinson in E flat. Ps. 216.

J. Ronisson.

Catherlral Muse... by Dr. William Inyce (see abuve, under 'Croft'), vol. i., I 760.

Stafford Smith in A. Hy. 64t.

J. S'tafford Simtit.

Twelve Chants eomposed for the use of the Choirs of the Chureh of Englanel, hy John Statforl smith, [ rire r $80_{5}$ ].

Soaper in D. $11 y .117$.

I. SOAprer.

Cliants, Ancient and Morlern, in seore, edited by John fins, I $S_{+}$I.

Stainer in B minor. Iy. 643 .

I. STMINER.

The Chureh Hymmary, is 89 .

Composed for the worls to which it is set.

Stainer in C. $1 / y, 644$.

.J. STATAER.

St. Paul's Cathedral Cliant Book. A Collection isined privately for use in the Cathedral in 1872 . Afterwarts published in C'athedral I'salter Chants, I877.

Tallis in F. I's. 184.

T. TALLIS.

Set to the 'Venite' in Tallis's Service, Preces and Litany, as printed in Boyce's Cathedral Music, vol. i., 1760.

Tallis in C. Hy. $64 t$.

T. Talis.

This is ascribed to Tallis in Cathedral Psalter Chants, but 
Chants-continued.

there seems to be little or no evidence in support of the statement. It appeared without any composer's name in 'The Preces and Litany, set by Thomas Tallis . . . with some Chants of the xvi and xvii centuries from MSS. of Dean Aldrich, edited by the Rev. H. E. Havergal, [1847].' $\Lambda$ chant having exactly the same melody but different harmony appeared in 'Sixty Chants, Single, and Double . . . composed by the ehoirsters of St. Paul's Cathedral, I795.' The chant is No. I in this collection, and has the name 'G. Williams' attached as composer.

Troyte in E flat. Hy. 290, 365 .

A. H. D. Troyte.

Forty-eight Hymn Tunes MS. or less known for hymns in the Salisbury Hymn Book, i 860.

The present is dated 1848 .

Troyte in G. $\mathrm{Hy} .584$.

Adapted from IV. HaYes. Forty-eight Hymn Tunes (as above), I86o.

The present is dated 1850 . It is an abridged version of a ehant by Dr. W. Hayes.

Turle in C. Ps. 217.

J. TurLe.

Single and Double Chants, eomposed for the use of the Choral Service of Westminster Abbey, by James Turle, [ 1855 ].

The present is headed 'Purcell Commemoration Chant, used in Westminster Abbey 5th evening of the month.' The original key is $\mathrm{D}$.

Turle in D minor. Ps. 218.

J. Turle.

Chants, Ancient and Modern, in score, edited by John Goss, I84 I.

Turle in F. Ps. 219.

J. Turle.

Single and Double Chants, composed for the use of the Choral Service of Westminster Abbey, by James Turle, [I 855].

Turle in E. Hy. 641.

R. Turle.

Cathedral Chants, edited by Alfred Bennett and William Marshall, I829. 
Cinasts-continued.

Wesley in F. Ps. 187.

S. S. WESLEY.

$A$ Selection of Psalms and Iymns arranged for the Public Services of the Chureh of England, edited by the Rev. Charles Kemble and S. S. Wesley, 1864.

Wesley in E. IIy. 304. P's. 220.

S. W EsLey.

Composed for and published in one of Tincent Novello's collections of music for the services of the Roman Catholic Church. The exact title and late of the collection have not been ascertainet. The chant afterwards appeared in The Psalter or I'salms of liavil with Chants . . a arranged by Simuel Sebastian Wesley, $18+3$.

West in G. IIy. 640.

H. WEST.

Cathedral Chants, edited by Mlfred liennett and William Marshall, I829.

Woodward in B flat. I's. 188.

R. WOODWARD.

Cathedral MLusic, consisting of one compleat service, Seven Anthems, Several Chants, etc. . . . composed by Richard Woorward, Mus. D., Grganist of Christ Church Cathedral, I)ublin, $[1771]$.

Woodward in D. Ps. 2.23.

R. WOODWARD.

Cathedral Music ... by Richard Woodward, [177I] (as above). 


\section{SPECIAL SETTINGS}

Blessed be Jehovah. Hy. 637.

In its present form this seems to have been first printed in Sacred Harmony for the use of St. George's Church, Edinburgh, I 820 ; the arrangement being most probably the work of $\mathrm{R}$. A. Smith. It is an adaptation of a melody found in various forms in books of the seventeenth century, where it is always associated with the Latin hymn 'Stabat mater dolorosa.' In a Roman Catholic Gesangbuch published at Mainz in I66I it appears as follows :-

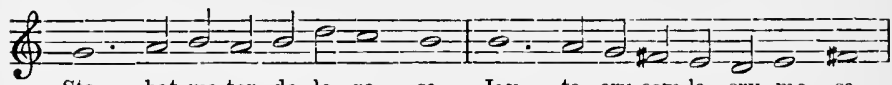

Sta - bat ma-ter do-lo-ro sa, Jax - ta cru-cem la - cry-mo - sa.

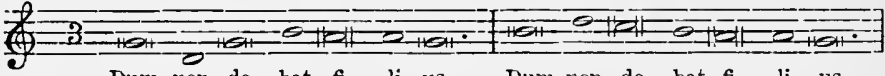

Dum pen-de - bat fi - li-us, Dum pen - de - bat fi - li - us.

In An Essay on the Church Plain Chant, ${ }_{17} 82$, and in Webbe's Collection of Motetts or Antiphons, 1792, it appears as follows:-
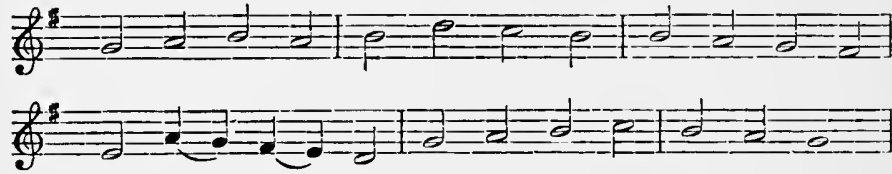

It was probably from this last that the present arrangement was made.

Glory be to the Father. IIy. 638 (1st setting).

A form of the Fifth Gregorian Tone, known in England as 'The Parisian Tone,' it being one of the late forms of the old Psalm Tones which came into use in France, especially in Paris and Rouen. 
Special SetTixgs-continued.

Glory be to the Father. Hy. 638 ( 2 nd setting). T. Taldis. From Tillis's Service, Preces and Litauy.

Sanctus. IIy. 639 (Ist setting). S. LEVEY.

1 Collection of Psalm and Ilymn T'unes, Chants, and other Musie . . arranged by A. R. Reinagle, Oxforl, i $S_{\text {fo. }}$

Sanctus. Hy. 639 (ㄹnd setting). J. STHINER.

The Chureh Hymnary, 1898.

Composed for this brulk.

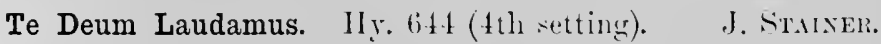
The Chureh Hymuny, isys.

Composed for this book.

Responses to the Commandments. Hy. 645) (1st setting).

l'. F. IIAMISLEY.

National Psalmoly . . . A Collertion of Tunes, ete. . . The Musie IIarmonised, Arranged, ant Adipted by b. Jacob, $\left[\mathrm{I}_{\mathrm{S}} \mathrm{1} 7 \mathrm{7}\right.$.

Incluiled in the Index in 'I Table of the New Compositions.'

Responses to the Commandments. IIy. 645 (:mul setting).

J. STAINEli.

The Chureh Iymmary, i 898 .

Composed for this book.

Responses to the Beatitudes. Hy. 646.

Alapted frum responses in Common Prayer with appropriate Musie, by W. H. Monk; and Responsive serviees, hy J. II. Ridelette.

The Lord's Prayer. Hy. 647.

The Apostles' Creed. IIy. 648.

J. STHANER.

Accompaniments written for The Chureh Iymmary, 1898.

The Lord bless thee. Hy. 649.

Arranged by I)r. Lowell Mason from a so-ealled 'Hebrew Psalter with notes' published by a German organist, who professed to have discovered in the Hebrew points some guide to the ancient music of the psalms. Modern Jewish authoritics 
Special Setrings-continued.

do not, however, admit that there is any foundation for the theory, or that the present is in any sense a Hebrew melody.

Dresden Amen. Hy. 650.

This old ecclesiastical cadence probably received its name from its use in the Court Church, Dresden. Several modern composers have made use of it, notably Mendelssohn in the 'Reformation Symphony' and Wagner in 'Parsifal.'

Threefold Amen. Hy. 650.

As used in the Lutheran Churches of Denmark.

Fourfold Amen. Hy. 650.

J. Stainer.

Composed for The Church Hymnary, 1898.

Sevenfold Amen. Hy. 650.

J. Stainer.

A Choir-Book for the Office of Holy Communion, edited by J. Stainer, 1873 . 


\section{CIIRONOLOGICAL LIST OF WORKS CITED AS SOCRCES}

1524. Gerstliche gesangk Buchlern, Wittenherg . . . 146

1531. Kirche Gesenge, Niirnberg . . . . . . 50

1531. Ein New Gesengluchlen, M. Weisse . . . . 116

1539. Geistliche lieder, Letipzig . . . . . . . 149

1539. Ein ansszug griter alter un newer Teutscher liedlein . T

1544. Ein Gesangluch der Brider in Behemen und Xerherrn 101

1545. Cerstliche Lieder, Leiprig . . . . . . . 81

1547. P'seaulmes cinquante de Darid, Lyons . . . . 34

1551. Pseaumes octante trois de Davil, Genera . 105, 107

1553. The Actes of the Apostles, Christopher Tye . 46, 60, 147, 163

1554. Fin Christlicher Aluentreien, X. Herman . . . 129

1556. The forme of pravers and ministration of the Sacraments, ete., used in the Englishe Congregation of

Genera . . . . . 103, 104, 108

$1560(?)$. The Whole l'salter, tranklated into English metre,

Archlishop Parker . . . . . . 55, 151

1562. The Whole Booke of Psalmes, collected into Englysh

metre . . . . . . 104, 118, 128

1568. Christlichs Gesangl,iichlein, M. C. Spangenberg . . 144

1591. Magnificat octo tonorum, Palestrina . . . 110, 157

1591. The former Booke of the Musicke of MI. William Damon $46 \mathrm{f}$

1592. The Whole Booke of P'salmes with their wonted Tunes,

composed into foure parts . . . . $30,4 \bar{\tau}, 162$

1598. New Catechismus Gesangliichlein, Hamburg . . 95

1599. Frewden Spiegel dess ewigen Lebens, P. Xicolai . . 100

1599. Harmonite hymnorum schole Gorlicensis . . . 113

1601. Lustgarten Neuer Teutscher Gesïng, H. L. Hassler . 111

1605. Em ander new Opus Geistlicher Deutscher Lieder,

B. Gesius . . . . . . . . . 87

1609. Ein sehön geistlich Gesangbuch, II. Vulpius . 24

1615. The CL. Psalmes of Javid in Prose and Afeeter, Elin-

burgh . . . . . . . $3,48,59,92,164$ 
1615. Ein andächtiges Gebet, so wol ein trüstlicher Gesang . 141 1619. Catholische Kirchen Gesäng, Cologne · · 97 1621. The Whole Booke of Psalmes, T. Ravenscroft 25, 48, 62, $101,127,143$

1621. Llyfr y Psalmau, E. Prys

. 134

1623. The Hymnes and Songs of the Chureh, G. Wither 10, 60, 136 1625. [Psalms in Metre], Aberdeen . . . . 23,51 1625. As hymmodus sacer, Leipzig . . . . . . . $\quad$. 25 1628. Trost-Liedlein, J. H. Schein . . . . . . $\quad$. 51 1633. The Psalms of David in Prose and Metre, Aberleen . 4 1634. The Psalmes of David in Prose and Meeter, Edinburgh 1635. The Psalmes of David in Prose and Mecter, Edinburgh $\quad . \quad . \quad . \quad . \quad . \quad . \quad .26,85,33,161$

1638. A Paraphrase upon the Divine Poems, G. Sandys . . 83 1639. Vollständige Psalmen und geistliche Lieder, Bremen . 41 1642. Fünfter Theil der Arien, H. Albert . . . . 62 1648. Praxis Pietatis Melica, J. Criger, 3rd edition . . 102 1653. Praxis Pietatis Melica, J. Criiger, 5th edition _ . $\quad 63$ 1657. G. Neumarks . . Musikalisch-Poetiseher Lustwald . 98 1657. Heilige Seelenlust, J. Angelus Silesius and G. Joseph 11, 43 1664. Neue geistliche . . . Andachten, J. R. Ahle . . . 42 1671. Psalms and Hymns in Solemn Musiek, J. Playford 85, 113 1674. An Introduction to the Skill of Musick, J. Playford, 7th edition. . . . . . . . . 166

1677. Niirnbergisches Gesang-Buch . . . . $\quad$. 69 1678. Praxis Pietatis Meliea, J. Criiger, 19th edition . . 144 1680. Joachimi Neandri Glaub- und Liebesibung - $\quad 13,98,115$ 1681. Auserlesenes Weinmarisches Gesangluch . . . 15 1684. Nener Helicon ... Das ist: Geistliche Sitten-Lieder,

Nuirnberg . . . . . . . . . 130 1686. Liineburgisches Gesaugbuch . . . . . 9 90,93 1690. Musicaliseh Handbueh der Geistlichen Melodien, Hamburg . . . . . . . . . . . 38,50 1693. Neu-vermehrtes . . Meiningisches Gesangbueh . . 119 1697. Select Psalms and Hymns for the Parish Church of St. James's, Westminster

1698. Geistreiches Gesang-Buch, Darmstadt . . . 13, 17

1699. Tunes of the Psalms, E. Ireland . . . . . 32

1700. A Sett of New Psalm Tunes, J. Bishop . . . . . 76

1704. Geistreiches Gesang-Buch, J. A. Freylinghausen 13, 86

1706. The Psalus of David in Metre, W. Barton . . $\quad 33$

1707. Oeffentliche Kirchen-Gesiinge, Bremen . . . . 10 
1708. A Supplement to the New Yersion of Psalms ly Dr. Brady and Mr. Tate, fith edition . . 6is, 123, 135

1708. Lỵa l)avidica

1709. The bivine Companion, 11. Play ford, 3rd edition 36, 39, 133

1715. A Collection of P'salm Tumes, John and James Green, 3rd edition

1715. Psalmodia Silcra, fothal .

1718. A liook of l'silmoly, J. C'hetham . -25) $1(3 ; 3$

1723 (?). The Jivine Musick sicholar. (inicle, F. Timhrell

1730(?). A book of Psillnody, M. Wilkin.

19,150

1731(?). A Choice (ollection of P'saIm Tunes, MI. Broom

1731. Evangeliccles ('horal-Buch, C. H. Dretzel

1734. A Compleat Melody, W. Timsur.

1736. Musicalisches Ciewing-liurh, (i. (C. sehemelli .

1738. A sett of New P'silm Thue's, W. Knaly'

1738. Harmon ischer Lienler-Sichat\%, J. B. Kinnig

1741. Nenes... Kirehen und IFanss-Gesang der... Tochter Sion, Cologrue

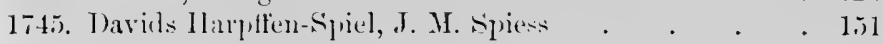

1749. [Chureh Tune- J. Challuers, Aberdeen . . . 138

17.9. A collection of IIymus and sacred l'oems, Dublin . 78

1751. Cantus Diversi, Mis., J. F. Wade . . . . . 7, 72

1753. The Spiritul Man's Companion, J. Ifoldroyd, stherition 136;

1754. Vollstindiges . . Choral-Bueh, J. 1). Miiller . . 79

1756. The Psalm Singer's Pocket Companion, T. Moore . . 61 1760(?). A Collection of Tunes, C. Ashworth . . . . 141 1760-8. Cathedral Mnie, W. Boyce . . 167, 169, 170, 171

1761. Choralbuch, IIs., Iresden . . . . . . 132

1762. Parochial Harmony, W. Riley . . . . . 8 $82,1 \pm 6$

1764. The New Ifamony of Zion, Wr. Tans'ur . . . 1233

1765. Twelve Hymus, J. Battislill .

1768 (?). Fifty lounl,le and single Chants. . . 165, 168, 169

$1769(?)$. Sixteen Hymms, B. Milgrove

1769. A Collection of P'salm and Ifymn Tmes, M. Madin 74, 96

1769. J. S. Bach's Vierstimmige Choralgesinge

15,95

17\%. Divine Iarmony, T. Vandernan .

165,166

$1770($ ?). A Collection of Psalm T'mes, I. Smith

$65 \quad 140$

1770. Williams's New Universal Psahmodist.

23,41

$1760(?)$. Palmody in Miniature, Williams

17TI(?). Cathedral Music, R. Woodward .

1774. Divine IIarmony, R. Langdon 
1774(?). Katholisches Gesangbuch, Vienna . . . . 110

1779. The Gospel Magazine, Norember 1779 . . . . . 94

1780. Twelve Psalm Tunes, T. Jackson . . . . . . $\quad .79$

1780(?). Retirement: A Glee for 3 Voices, H. Harington . 67

1782. An Essay on the Church Plain Cliant 6, 37, 72, 93, 103, 174

1784-91. Sacred Harmony, R. Harrison . . . 112, 159, 168

1784. Choralbuch, C. Gregor . . . . . . . . 83

1786. A Collection of Psalm Tunes, S. Addington, 6th edition 27

1789. Ten Church Pieces for the Organ, W. Jones . . . 99

1789(?). The Hymns and Psalms used at the Asylum . . . for

Female Orphans . $\quad . \quad$. $\quad . \quad$. $\quad . \quad$. 95

1790. Psalmodia Evangelica, T. Williams . . . $\quad .154$

1790. The Psalms of David, E. Miller . . . . 23, 35

1790(?). A Collection of Hymns . . . for the Liverpool Blue

Coat Hospital . . . . . . . . . 157

1791. The Psalms of David, S. Arnold and J. W. Callcott . 12

1793. A Select Collection of Psalm and Hymn Tumes, H.

Boyd . . . . . . . . . . . 45

1794. The Psalms of David, W. D. Tattersall . . . . 91

1795. Sixty Chants... by the Choirsters of St. Paul's

Cathedral . . . . . . . . . 172

1795 (?). A Selection of Psalm and Hymn Tunes, J. Rippon . 153

1795 (?). Divine Amusement, G. T. Smart . . . . 161

1798. The American Musical Miscellany . . . . 74

1799. Vollstäudige Sammlung . . . Choralmelodien, Clırist-

mann and Kneclit, Stuttgart . . . $\quad 81,116,158$

1802. Dr. Watts's Psalms and Hynms set to new music . . 146

1805(?). Twelve Chants, J. Stafford Smith . . . . . 171

1808. The First Verse of every Psalm of David, with an ancient

or modern Chant, Beckwith . . . . . . 165

1808. A Collection of Psalın Tunes, S. Webbe, jun. . . 131

1808(?). Euphonia, W. Dixon . . . . . . . . 131

1810(?). A Selection of Single and Double Chants, J. Clarke

[-Wlitfeld] $\cdot \quad \cdot \quad \cdot \quad \cdot \quad \cdot 167,170,171$

1810(?). A Collection of Chants, W. Cross . . 168, 170, 171

1810(?). A Second Set of Psalm Tunes, T. Clark . . . 39

1810. Devotional Music, R. A. Snith . . . . 133

1812-5. Sacred Melodies, Wm. Gardiner I9, 20, 140, 158

1815. Choralbuch, J. G. Werner, Leipzig . . . . 115

1817. National Psalmody, B. Jacob . . . . 20,175

1820. Sacred Harmony for the use of St. George's Church,

Edinburgh . . . . . 34, 117, 129, 174 
1822. [Mass by D. Bortniansky]

1824. The Ifymm Tunes of the Chureh of the Brethren .

1824. The Boston Handel and Haydn Society Collection, 3rd edition

1825. Sacred Music sung in st. (ieorge's Churel, Edinburgl,
Ii. A. Simith
. $78,92,12-1,136,145$

1825. A Selection of Psalm 'Tunes for st. Mary's Church, Edinlurgll, J. Wilson

182.5. Vier:timnige Gesinge, Stuttgart

1826. l'arochial P'silnorly, J. (ioss.

18:66. The Spanisis IIsmu, J. Carr .

1829. Cathedral Chants, $A$. Bennett and W. Marshall $16 \bar{\pi}, 168$, $171,172,173$

18.29. The Boston Inandel and Haydn Society Collection, 9th edition

1831). I'salm Tunes, A. R. Reinagle

1830. A Collection of Palm Tune, C. Bryan. . . . 145)

1831. P'arochial P'salmody, J. P’. Clarke, zind edition . . 80

1833. Spiritual fongs for social Worship, T. Hastings and

$$
\text { L. DFason . . . . . . . } 97,108
$$

1833. A Selection of Original Sacred Music, J. Thumbull . 16

1833(?). Vollstindige Sammlung der Afelodien zum Maanzer Gesungluelse . . . . . . . . . 51

1834. Chants C'hrétiens, Paris. . . . . . . . . 120

1835. Buston Acarlemy Collection, L. Mason . . . . 71

1835. Cal vary ; an oritorio, L. spohr . . . . . . 147

1836. The Paslmist, V. Novello, l'art II. . . . . . 160

1836. A II undred Chants, W. II. Havergal . . . . . 168

18:37. The Odeon, (i. J. Wêh, and L. Mlason . . . . 96

18:37. P'silms amd IIymmis, J. B. Sale . . . . . 4i

1838. The P'silmist, V. Novello, P'art ill. . . . . . 03.

1838. P'al'ochial P'salmody, P'art II., J. liows . . . . I6f;

18:38. Stimmen ans dem Reiche Gottes, (C. Korher. . . . 4t

1839(!). Antlemes and siacred songs, A. 11mme . . . 66

1810. Cantica Sacra, C. Ett, Junich . . . . . 108

1810. l'salm xiii., Mlentelssuln . . . . . . . 36 ;

18 40. Festgesing, Mendelsohn . . . . . . . 21

1840. Songs and Ballads, Princes Albert and Ennest . . 63

1840. A Collection of P'salm and Hymn Tines, A. R. lieinagle . . . . . . . . . 175

1841. Cliants, Ancient and Modem, J. Ciuss . . 166, 167, 168, $169,171,172$ 
1841. The Sunday School Teachers' Magarine 1841 (?). Mainzer's Choruses . . . . . . 90 1842. The 'Tune Book to the Hyuns and Cliaunts for Sunday

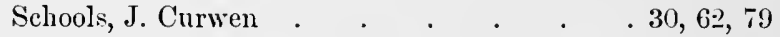

1842. Lieder-Buch fïr Kleinkinder-Schulen, T. Fliedner • 44

1843. The Psalter, S. S. Wesley . . . . . . . 173

1843. Sacred Melodies for Children, C. H. Bateman 119, 152

1843. The Juvenile Harmonist, T. Clark . 30, 80

1843. 'The Sacred Harmony of St. Andrew's Chnreh, Elinburgh 75

1844. A Collection of Psalm and Hymn Tunes, J. Turle and

E. Taylor . . . . . . . . . . 53

1814. Twenty-four Psalm Tunes, W. Horsley . . . . . 73

1814. Hausehoralbuch, Giitersloh . . . . . . $\quad .90$

1845-7. Cantica Spiritnalia, Mnnich . . . . . . 11

1846. The Comprehensive Tume Book, H. J Gauntlett . . 148

1846. Church of England Psalmody, H. Parr . . . . 101

1847. The Preces and Litany, etc., H. E. Havergal . . . 172

1847. Vierstimmiges Choralbuch, F. Filitz . . . 28, 58, 90

1848. A Collection of Tumes and Chants, J. Hopkinıs . . 165

1848. The National Psalmist, L. Mason and G. J. Webb. . 148

1849. Church Psalmody, C. Steggall . . . . 122, 136

1849. Catholic Hymn Tunes and Litanies, J. M. Capes . $\quad 87$

1850. Cantica Laudis, L. Mason and G. J. Webb . . $\quad 25$

1850. New Carmina Sacra, L. Mason . . . . . 55, 124

1850. The Anglican Chant Book, E. G. Monk . . . . 169

1850(?). L. Erk's Weihnachtslieder, Berlin . . . . . 114

1850-1. The Parish Choir . . . . . . . 77,131

1851. Easy Hymn Tunes for Catholic Schools · . 125, 149

1851. The Standard Psalm Tune Book, H. E. Dibdin 147, 154

1851. The Hallelıjah, J. J. Waite and H. J. Gamntlett . . 9

1851. The Bible Class Magazine, July $1851 \quad$ • $\quad$ • $\quad$ • $\quad$. 151

1852. The Church Hymn and Tune Book, W. J. Blew and H.

J. Gauntlett . 70, 122, 129, 131, 137, 147, 153, 154

1852. The Choral Adrocate . . . . . . . 95

1853. Easy Mnsic for Church Choirs, Part III. 78, 123

1853. Church Hymu Tumes, R. Redhead . 82, 109, 113, 127

1853. The Anglican Chant Book, E. G. Monk, 2 nd edition 168, 170

1853. Collection of Catholic Hymns, H. Formby and J.

Lambert . . . . . . . . . 153

1853. Congregational Church Music . . . . . $\quad$. 31

1853. Kern des deutschen Kirchengesangs, F. Layriz, Part III. 12

1854. The Hallelujah, L. Mason . . . . . 58, 118 
1854. Choral IIarmony, P. Maurice

I'AGE

185f. The Clumeh Psalter and Hymu Book, W. Mercer .

22,57

1854. The bihle Class Magazine, November 1854

23,124

1855. 'The Metrical P'salter, II. Lahee

45

98

18.55. Single and bouble Chants, J. Turle

172

1855. Zimblarfe, C. Kocher.

71,137

18.56. Hrmmil Foted, Part 11.

37,156

1857. A Namual of P'salm and Hymn Tunes, J. Grey . 5 57,137

18\%. Chants as used in Wustminster Abbey, J. Turle . . 169

1858. Seottish P'silnody, enlarged (3ri) edition . . . 84

1858. Choral llarmony, with supllement, P. Manrice . 42, 52

1858. A Selection of Prilm and IIym Thues, E. H. Thorne. 130

18is. The Congregational P'salmist, 11. Allon . . 100, 147

18.8. Hrmms for Little Chilelren, H. J. (rauntlett . . . TR

18.59. A Hundred P'silm and Hym Thnes, W. H. Havergal 50, 16t

18.59. The Village Churel Tune Book, T. R. Matthews . . 29

1859. C'hurel llym Tunes, li. Redliead, Ond series . . 137

1859. Ancient Hym Velodies, R. Rerlhear . . 94, 128, 142

1860. Old Chureh P'salmody, W. H. Harergal, sthedition . 119

1860. Forty-eight Iymn Tumes for the Salisbury Irmu Book 172

1860. Church and Ifone Metrical Paslter and Hymal, C. II.

Purlay

143

1860. 'l'i aandelige Sange af Emil Hlartmant . . . . . . 37

1860. The Bible Class Magazine . . . . . . 62

1861. Hynus Ancient and Ilodem . 43, 56, 60, 71, 72, 89, 93, 9.4,

$95,10(1,10.2,114,12.5,126,1.27,1.28,135,140,1.17,150$

1861. The Congregationil P'silnist, 11. Allon, l'art 111. . 73, 160

1861. New Palm and Hyun Thunes, J. Barnly . . . . 72

1861. The Golden Chain, W. H. Bradbury . . . . . 79

1861. The Chorale book, II. H. Bemrose and W. Adlington . 129

1861. Two C'hri-tmats Cirrols. . . . . . . 65

1*6:- The Congregitional Hymn anm Thue Book, R. li.

Chople . . . . 14, 5.2, 53, 70, 120, 1.2.2, 12.4,

$12-130,131,134,1.10,141$

186.2. Congregational Melorlies, T. R. Matthews . . . 101

1862. The Journal of Part Musie, (i. W. Martin . . . 83

1862. The bay is past and over, ete, A. 11. Brown . . 71, 12.2

1862. Songs of l'raise and Ten other Hymns, W. B. Gillbert 90, 152

186.9. The Chureh of Scotland Hym Tune Book . . . 110

1862. Hymns for Infant Chillen . . . . . . 58

1862. Richard Wearer's Tune Book . . . . . . 22

1862. The Psalter, F. A. G. Ouseley and E. G. Mlonk . . 170 
1863. Psalms and Hymns, J. Foster

1863. A Selection of Psalm and Hyım 'Tunes, E. H. Thorne, enlarged edition $49,126,132,145$

1863. The Bristol Tune Book, 1st series .

1863. Psalms and Hymns for Public Worship, J. Turle . $9,49,166$

53,128 , 132,139

1863. The Merton Tune Book, L. G. Hayne . . . 36, 94, 126, 133 1863. Katholisches Gesangbuch, St. Gallen . . . . . 112 1864. A Selection of Psalms and Hymms, C. Kemble and S. S.

Wesley · 14, 15, 28, 31, 35, 52, 61, 73, 153, 162, 173 1864. The Church Psalter and Hymm Book, Rearranged edition . . . . . . . . . . 112 1864. Hymns of the Eastern Church, E. R. Barker . . . . 41 1864. The Song Garden, L. Mason . . . . . . 44 1865. The Holy Year, C. Wordsworth . . . . . 9, 164 1865. Hymns for the Church of England with Proper Tunes,

\section{Steggall}

1865. [Sixteen Tunes], T. R. Matthews

1865. Happy Voices

1865. Sacred Harmony, E. Bumnett

1865. [Hymn Tunes], S. Smith

1865. The Church of Scotland Hymn Tune Book . 1866. A Hymmal for use in the English Church 1866(?). The St. Albans Tune Book.

1866. 'The Praise Book, W. Reid

1866. The Dove, Chicago.

1866. Advent Hymn, J. Tilleard

1866. Our Song Birds

1867. Psalms and Hymns for Divine Worship

$$
\begin{array}{rrr}
. & . & 149 \\
. & 72,118 \\
. & . & 18 \\
. & . & 130 \\
. & . & 120 \\
. & . & 98 \\
70, & 118, & 121 \\
. & 41,121 \\
. & . & 52 \\
. & . & 86 \\
. & . & 80 \\
. & . & 161
\end{array}
$$

1867. One Hundred Hymn Tumes, H. Lahee .

1867. The Temple Church Choral Service, E. J. Hopkins 40, 152, 169 1867. Psalms and Hymns, D. T. Barry . . . . . 88 1867. The Supplemental Hymn and Tune Book, R. Brown . 4, 21, $28,64,146$

1867. Twenty-two Original Hymn Tunes

1867. Christmas Carols New and Old, H. R. Bramley and John Stainer, 1st series

1868. A Hymnal, chiefly from The Book of Praise, J. Hullah

1868. Hymns Ancient and Modern, Appendix $9,29,31,43,45$, $50,60,82,110,112,113,149,156,157,161$ 
1868. The Leeds Tune Book, J. Lancaster . . . . 75

1868. Catholic Iymms, E. R. Barker . . . . . . 38

1868. Sabbath Sehool Songs, H. R. Palmer . . . . 59

1869. The Sarum Iymmil . . . . . . $\quad 8 \overline{7}, 11 \overline{7}, 139$

1869. C'hurch P'salter and Hymnal, H. J. Gauntlett • 24, 28

1869. Original 'Tumes, .l. Barmby . . . . . . . 8

1869. The Supplemental IIsmn and Tune Book, R. Brown-

Borthwiek, 3ril edition . . . . .49,51, 114, 115

1870. The Otfiee of Praise, II. J. Gauntlett . . . . 88

1870. Christmats Carols, H. R. Bramley and J. Stainer, End

$$
\text { series. . . . . . . . . . . . . . 75 }
$$

1870. Songs of Jerotion, W. H. Doane . . . . . . 12

1871. The Scottisl Irmmal . . . . . 95, 112, 131

1871. Oratory Hymu Tunes, W. Pits . . . . . . 117

187. Inavergal's P'salmody . . . . . . . . 51, 69, 70

1871. The Charm, Cincimati . . . . . . . 197

1871. The Anglican Hymn Book, Revised edition . . . 143

1871. Congregational Churel Musie, Enlargerl edition . . 146;

1871. The Chant-bork supplement to the Hymnal Companion 167

1871. Six Satred Part Songs, A. S. Sullivan . . . . 89

1872. The Hymmary $8,-27,36,50,57,633,73,81,86,89,9.2,94$,

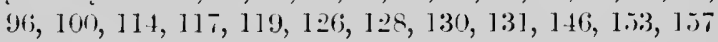

187.2. The European P'silnist, S. S. Westey . (69, 160, 163

187.2. IIym Tunes, E. H. Turpin . . . . . . 12

1872. The Church Psalter and Hymm Book, Appendix . . 12

1872. Ciood Words, January 1872 . . . . . . . 38

18\%.-. The Northern Palteri, W. C'arnie . . . . . . 39

18\%.2. St. Paul's Cathedral C'hant book . . . . . . 171

187.2. The Bradiond Tume Book, Aplendix . . . . . 52

1873. The Christian Hymul. . . . . . 36, 101

18i3. Farourite llym Tunes, F'. Sunthgate . . . . . 121

1873. London Chureh Choir Asociation Festival service . 118

1873. A Choir-book for the Uflice of Iloly Communion, J.

Stainer . . . . . . . 176

1874. Chureh Hyuns with Tunes . . . 30, 31, 3:2, 41, 4.2, 5.5,

$$
56,58,6: 2,78,83,87,88,92,93,100 \text {, }
$$

$115,1 \div 6,1.39,138,14 \cdot 2,143,1+8,155$

187. Chureh Iymmal (I rish Episcopral) . 4, 32, 5i3, 81, 108, 1:4, $1.27,131,1+2,156$

1874. The North Cuates Supplemental Tume Book, T. R.

Matthews . . . . . . . . 31, 116

1874. Hymnal with 'lunes Old and New, New York 122, 154 
1874. Ten Original Tunes, A Cottman . . . . $\quad 16$ 1875. Hymns Ancient and Modern, Enlarged edition 4, 9, 14, 17, $23,34,35,39,58,61,73,76,83,94,99,117,121$, $122,124,128,134,136,138,143,145,148,152,155$ 1875. Hymus for the Church of England with Proper Tunes, C. Steggall, 2nd edition 134

1875. The Congregational Psalmist, H. Allon, Appendix II. . 28,

1875. The New Mitre-Hymnal $113,145,153$ 1875. The Burnley Tume Book . $8,54,132$ 1876. The Song of Praise, V. Evans-Freke

1876. Songs of Love and Mercy $12,27,29,44$ $54,56,79,89$ 1876. The Bristol Tune Book, 2nd series 133,140 1877. The Hymnal Companion, 2nd edition . . 8, 54, 61, 112 1877. The Temple Church Choral Service, Supplement . 58, 64, 151,161

1877. Hymns for Mission Services .

1877. The London Tune Book

1877. The Presbyterian Hymmal : . $\quad 14,21,60,80,95,122$

1878. Christ and His Soldier's, J. Farmer

1880. The Temple Church Choral Service Book . . 64, 155

1880. Twenty-four Original Tunes, E. Bunnett 21,99

1880. Twenty Hymns for Children, L. J. Hutton . . . 159

1881. The Methodist Sunday School Tune Book • 11, 21, 54, 148

1881. The Children's Hymu Book 30, 34, 65, 69, 98, 154, 160, 166

1881. The Bristol Tune Book, Supplement . . . . 132

1881. Hymnal of the Presbyterian Church in Canada . . 34

1882. The Presbyterian Hymmal for the Young . . . 78

1883. Church Praise . . . . . . . . . $\quad$. 89

1884. Hymn Tunes, W. D. Maclagan . . . . . $\quad$. 80

1885. The Scottish Hymmal . . . 14, 40, 50, 59, 130, 134

1885. The National Book of Ilymn Tunes . . . 64, 190

1885. The Chenies Tune Book . . . . . . . . 76

1885. The Lowestoft Supllemental Tune Book . . 99

1885 (?). Sacred Leaflets, R. Jackson . . . . . . 11

1886. The Congregational Psalmist Hymnal, I1. Allon • 36, 54, 85

1886. The Book of Psalms and Paraphrases . . . $\quad 99$

1887. The Congregational Church Hymnal . . 56, 82, 84, 95,

$101,115,124,150$

1887. The Crucifixion, J. Stainer . . . . . 9, 97, 40

1887. School Hymnal Tune Book, J. Adcock . . . . 164 
1889. Hymus Ancient and Modern, Supplement 3, 38, 94, 147, 148 1889. Hollingworth's Psalmody . . . . . . . 62 1890. Life and Work, January 1890 . . . . . 61 1890. The Ifymal Companion, 3rd edition . $\quad 71,109,144,158$ 1890. The Congregational Mission IIymmal 31, 45, 71, 91, 154, 156 1891. The Congregational Sunday Sehool Hymnal . 20,31, 52 1891. The Bristol Tune Book, 3td series . . . 30, 114 1892. The Home and school Hymnal . 22, 40, 80, 135, 152, 161 1894. Under Lochnagar . . . . . . . . . 39 1895. The ('hureh of England Hymuil . 8, $16,21,49,59,61,76$, $80,94,97,145,152,156$

1896. Original Irmu Tunes, F. [1. Nykes . . . . 71

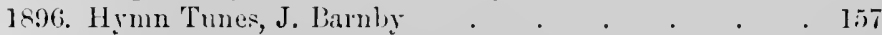
1897. The Westminster Albey Hym Brok . . . 6으, 11 T 1898. The Chureh Hymuary 24, 25, $27,28,30,34,38,39,43,45$, $56,57,58,59,61,64,67,69,70,71,79,80,82$, $84,96,103,112,113,117,118,119,125,144,146$, $149,152,153,155,156 ;, 161,164,171,175,176$

The new tunes, printed for the first time in The Clumreh Ifymary, were contributed by the following composers :-

Alcoek, Stanley.

Alcork, Walter, MIus, Bac.

Booth, Josiah.

Bridge, Sir Frederiek, Mus. Doc.

Elliott, Janes IV.

Faning, Eiston.

Foster, M. Birket.

Ilaynes, Battison.

Hervey, Rev. Frederie A. J.

Linekirr, Thomas J.

Mann, Arthur II., Mus. Doe.

Martin, Sir (ieorge C., Mus. Woe.

Monk, Mark J., Mus. Doe.

Parrs, sir C. II. H., Mus. Doc.

Somervell, Artluu.

Stainer, Sir John, Mus. Duc.

Sweeting, Elward T., Mus. Doc.

Walton, Herbert.

Woods, F. Cumningham. 


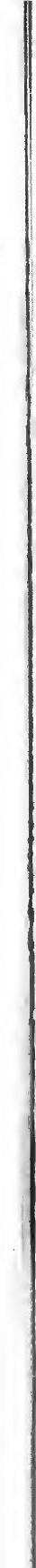




\section{PART II \\ BIOGRAPHICAL NOTICES \\ OF THE \\ COMPOSERS}




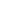




\section{BIOGRAPHICAL NOTICES}

OF TIE

\section{COMPOSERS}

Adcock, John, born at Loughborongh, Angust 31, I8 83 ; at the age of ten he joined the church choir and sang solos at oecasional coneerts; when sixtecn he became usher in a boarding-school at Spalding, and was appointed choirmaster of the ehapel and conductor of a choral society; about i 858 entered the music establishment of Mr. Henry Farmer at Nottingham, and rose to the position of manager, holding that office until Mr. Farmer's death in $189 \mathrm{I}$; choirmaster at Castle Gate Chureh, Nottingham, for twenty-one years; on the retirement of Mr. Farmer, appointed conductor of Nottingham Sacred Harmonic Society, holding the position for sixteen years; compiled The School Hymnal Tune look, to which he contributed a number of tunes.

Ahle, Johann Rudolph, born at Miihlhhausen in Thuringia, December 24, 1625; edneated at the Universities of Göttingen and Lrfurt; cantor of St. Andreas' Clureh, Erfurt ; organist of St. Mlasius' Church, Mrilhlhausen, in 1649 ; six years later member of the council, and in $\mathbf{1 6 6} \mathbf{I}$ burgomaster of Mühlhausen ; died there July 1673.

Albert (Prince), Francis Albert Augustus Charles Emmanuel, Consort of Queen Vietoria; born at the Rosenau, near Coburg, August 26, 1819; died at Windsor Castle, December 14, 186I. His compositions inelude a choral service 
and an anthem for the church, many German songs, and a piece entitled 'L'Invocazione all' Armonia,' which was performed with success at the Birmingham Musical Festivals of I 849 and 1855 .

Albert, Heinrich, born at Lobenstein, Voigtland, July 8 (Old Style, June 28), I604; attended the Gymnasium at Gera, and became, in 1622 , a pupil of his uncle Heinrich Schuitz, at Dresden, but on the advice of his parents abandoned his musical studies and removed to Leipzig to study law. It is recorded that, in 1626 , he went to Königsberg in Prussia, and started with an embassy to Warsaw; but on the road he was taken prisoner by the Swedes, and did not return till $\mathbf{1 6 2 8}$, after enduring many hardships. The study of law had no charm for him, and he abandoned it on being chosen organist of the Cathedral of Königsberg in 1632, continuing his musical stucties under Stobäus. Albert was also gifted as a poet, and wrote the words of many of the songs which he set to music; died at Königsberg, October 6, $\mathbf{1}_{5}$ I.

Alcock, Stanley, son of Mr. Walter William Alcock; born at Twickenham, November I87 I ; self-taught amateur musician ; composer of several hymu tunes, chants, etc.

Alcock, Walter Galpin, elder brother of the preceding; born at Ednebridge, Kent, December 29, I86I ; studied under Sir Arthur Sullivan, Sir John Stainer, Dr. Prout, and J. F. Barnett; assistant organist at the Parish Church, Twickenham, I873; organist there, I879; organist of Quebec Chapel (now the Church of the Annunciation), Portman Square, London, I887; assistant organist of Westminster Abbey since I889; professor of the organ at the Royal College of Music, I893; organist of Holy Trinity Church, Sloane Street, London, I 896.

Aldrich, Very Rev. Henry, son of Mr. Henry Aldrich; born at Westminster, 1647 ; graduated B.A., Oxford University, I666; M.A., I669; B.D. and D.D., I68ı-82; took Holy Orders, I669; rector of Wem, Shropshire; canon of Christ Church, Oxford, I68I-82 ; dean of Christ Church, ı689; died at Oxford, December I 4 , I 7 I 0. 
Anderson, James Smith, son of Mr. William Anderson, town treasurer of the royal burgh of Crail, Fifeshire; born at Crail, June 30, I853; received his musical education at Eidinburgh under Mr. (now Sir) G. C. Martin, Mus. Doc., organist to the Duke of Buccleuch at Dalkeith, from his successor Mr. (i. F. Tendall, Mus. Bac., and afterwards at (ilasgow under 1)r. A. L. Peace; graduated MIus. Pialc., Oxford, 1878; Fellow of the College of Organist., Lomlon, 1878 ; organist and choirmaster of Nicolson Syuare Chapel, Eilinburgh, 1872 t" 1877; Abbey Parish Church, 1877 to 1879; St. Thomas's Episcopal Chapel, 1879 ; since 1881 has held the position of organist and choirmaster at St. Andrew's Parish Church, George Street, Edinburgh. Mr. Anderson has contributed to many Hymnals, and he revised the harmonies of the lHackburn Tune liook and of The Presbyterian IIymmal for the Young.

Arnold, Samuel, won of Mr. Thomas Arnoli ; born in Lomlon, Aurust Io, I7fo; studied in the Chapel Royal under liernarl (iates and Irr. Nares, and obtained the degree of Iloctor of Insic at Oxford in 1773 ; ten years later appointed organist and composer to the Chapel linyal, and in 1793 organist of Westminster Abbey; died (1)tober 22, 1802, and was huried in Westminster Albey.

Ayrton, Edmund, born at Iipon, 1734; chorister in York Ninster, unler I)r. James Nares, 1747; organist of Southwell Minster, 1754; gentleman of the Chapel Royal and vicar choral of St. Paul's Cathedral, 1767 ; lay vicar of Westminster $A$ bbey, 1780 ; Mus. Doc., Cambridge, $178+$; manter of the children of the Chapel Royal, 1783 to $180_{5}$; died Mlay 22 , I 808 ; buried in the north cloister of Westminster $A$ bbey.

Bach, Johann Sebastian, son of Juhann Ambrosius liach; born at lisenach, March 21, 1685 ; sturlied at Ohrdruff, where his elder bruther Johann Christoph was organist, and at Luineburg. After occupying positions of importance at Arnstalt, Mrihlhausen, Weimar, and Cöthen, he was in 1723 appointed cantur of the Thomas-Schule in Ieiprigr, and director of the music in two of the principal churches there. He died at Leipzig, July 28, $175^{\circ}$. 
Baker, Frederick George, born in the Isle of Wight, May 19, 1840; chorister in Winchester Cathedral for seven years, part of which time Dr. S. S. Wesley was organist; studied harmony under Dr. Iliffe,-otherwise self-taught; organist of Christ Church, Sandown, Isle of Wight, from 1864 to I872; since then organist of St. Saviour's, Shanklin, Isle of Wight.

Baker, Henry, son of the Rev. James Baker, chancellor of the diocese of Durham; born at Nuneham, Oxfordshire; educated at Winchester School; graluated Mus. Bac. at the University of Oxford in 1867 ; is a civil engineer.

Baker, Rev. Sir Henry Williams, son of Vice-Admiral Sir Henry Loraine Baker, C.B.; born in London, May 27, I821 ; after completing his university education at Trinity College, Cambridge, took his B.A. degree in 1844 , and proceeded to the degree of M.A. in 1847 ; in 1851 presented to the vicarage of Monkland, near Leominster; on the death of his father, November 2, 1859, succeeded him as third baronet; died at the vicarage of Monkland, February 12, 1877, and buried in the churchyard of the parish. He was one of the original projectors in I 858 of Hymns Ancient and Modern, and took a chief share in the compiling and editing of that work.

Barker, Elizabeth Raymond, daughter of Mr. William Hacket of Aylestone Hall, Leicestershire; born at Leicester, I829; pupil of G. A. Löhr; married in 1853 to the Rev. Frederic Mills Raymond Barker, M.A. of Oriel College, Oxford; joined the Catholic Church in I867, when she took the additional names of Mary Agnes. At the request of Dr. Neale, Mrs. Barker composed tunes to his Hymns of the Eastern Church; the first series, published in 1864 , contains six hymns which were set to music at Bisley, Gloucestershire, in 1863 .

Barnby, Sir Joseph, born at York, August I 2, 1838; in 1846 became a chorister in York Minster, where he remained till I 852 ; studied at the Royal Academy of Music, London; organist of St. Andrew's Church, Well Street, London, from 1863 till I87 I ; of St. Aune's, Soho, from I87 I to I886; in I 875 organist and precentor of Eton College; appointed con- 
ductor at the Royal Acalemy of Murie, I 886 ; revigned I 888 ; comluetor of the lingal Choral sixedy ; receiven the honous of knighthookl, $18 y z$, and in the sine your appointerl frincipal of

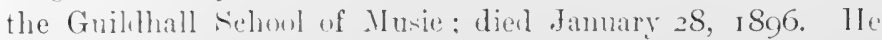
was a very prolitic witer of hymn tunes; a cullection of these, mumbering two humberl and forty-ix, having beren published sinue his deatle.

Barthélémon, François Hippolite, was burn at liomleatux, July 27. 1741. His father, Emmanuel diarthémon, helil during many years a respectable situation umler the French Government in one of theris colonial departments; and his mother, an Irish larly, wats of a wealthy fanily in (lneen's County. Joung liarthelimen wa for sume time an officer in lierwiek's liegriment in the Irish Jirigale. Ho marle the arquaintanee of the bill of Kellie, who being himself passionately font of music, soon hexime attached to liathélomon, and sueveeded in imlneing him to change lis profexion for that of music. Ife settlest in Fingland in 1765 , monder the protection and fratroniag of the karl of Kellie, and his success as a violinist was pronomed. In the same yar he beeame lanler

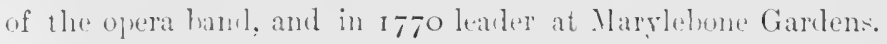

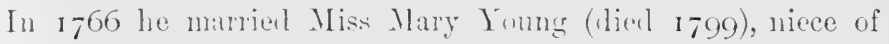
Mr. Ame and Mr. Lampe, and in 1776 hegan a profosional tour throush (iemany, Italy, aml Finnee. He also visited

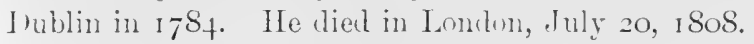

Battishill, Jonathan, son of Mr. Jonathan liattishill, solicitor, ant Mary Lererton of (ircat Torrington: lurn in Lumblon, May I738: "horister in si. Panl's Cathertral umber Willim Sarage, $17 f^{S}$; organist of the uniter prarishes of sit. Clement, last ('heal', aml sit. Martin, ()rgar, Lomlon; afterwarls of Christ Chureh, Sewgate street, 1767 : thed at Islington, lecentrer 10, 1Sor, and was buried in sit. Paul's Catherlinl.

Beaty, Richard William, born in I)ublin abont I799; edueated in Christ Clumeh Cathedral, I)ublin; appointerl about $182+$ organist and musieal instruetor at the Molyneux 
Asylum for Blind Women ; organist of the Free Church, Great Charles Street, 1828 to 1877 ; master of the ehoristers in Christ Church Cathedral from I 830 to 1872 ; lied in Dublin, I 883 .

Beckwith, John Christmas, born at Norwich on Christmas Day, $175^{\circ}$; pupil and assistant successively to Dr. William Hayes and Dr. Philip Hayes at Magdalen College, Oxford ; appointed organist of St. Peter's, Mancroft, Norwich, January 16, I794; gradnated MLus. Bac. and MLus. Doc. at Oxford in 1803 , and in 1808 succeeded Thomas Garland as organist of Norwich Cathedral, retaining his office at St. Peter's; died in consequence of a paralytic stroke, June 3, 1809; buried at St. Peter's, Mancroft. There is some doubt as to whether Dr. Beckwith was baptized John Christmas, or whether his second name was only a nickname. In the works he published he is described as John Beckwith, but in the register of his burial the name is stated as 'John Christmas Beckwith, married man, an organist of this parish,' and it is by this name he is generally known. Some years ago an endeavour was made to find in what parish Dr. Beckwith was born, but withont success.

Beethoven, Ludwig van, born at Bonn, Decenber 16, 1770; resided chiefly at Vienna, where he died March 26, I827; interred in Währing Cemetery; reinterred in the Central Cemetery, Vienna, June 22, 1888.

Bell, John Montgomerie, writer to the Signet; son of MIr. Alexander Montgomerie Mell, writer to the Signet and professor of conveyancing in the University of Edinburgh; born in Edinburgh, May 28, 1837, and educated there; studied music under P'rofessor Donaldson at the University; amateur composer of many fine hymn tunes, anthems, etc. Mr. Bell was a member of the Committee entrusted with the preparation of The Chureh IIymnary.

Bilby, Thomas, son of Mr. John Jilby ; born at Southampton, April I8, I794; served eight years in the army; studied the Infant School system under Mr. James Buchanan, headmaster of the 'Asylum for Infancy,' opened in 1818 by Lord Brougham 
and others at Brewer's Green, London; in 1825 Bilby took charge of the Training School at Chelsea, and about ten years later went to the West Indies, and introduced his system of teaching there; returned to England and became parish clerk in Sit. Mary's, Islington, an offiec he held for twentyeight years; one of the founders of 'The Home and Colonial Infant Sichool Society'; died September 24, I872.

Bishop, John, born about 1665 ; pupil of I)aniel Roseingrave; lay vicar of King's College, Cambrilge; appointer organist of Winchester College in 1695 ; sueceelen Vaughan Richardson as organist of Wincliester Catherlral, I729; dien lecember 1737 , and buried on the $22 n d$ of that month at the College of Winchester.

Bliss, Philip Paul, som of Mr. Isaae Iiliss; born at Clearfield, Clearfield County, Pennsylvania, July 9, 1838 . When twentysix years of age he went to Clicago, receiving employment from 1)r. G. F. Rout, the composer, and while there lis time was mainly spent in conlucting musical classes and in compwing sacred melorlies suitable for Simblay schools. Although originally of the Methodist persuasion, he entered the choir of the First Congregational Chureh, Chicagn, in 1871 , and becane superintenient of its Sabbath schools, three years later joining Major IBliss in evangelical work. Although a por man, he gave to this caluse the royalty of his Gospel songs, which was worth some thirty thousand dollars. His death was a sal one. It took place in the great railway disaster at 1 shtabula, (Ohio, U.S., December 30,1876 . He sueceeled in escaping from the car, but lost his life in attempting to save his wife. 'Mr. liliss,' says the Rev. 1)r. Julian, 'is usually kmown as "I'. I'. liliss." This is fomd on the title-page of his enllection. (On his own authority, however, wo are enabled to siy that his name origrinally stool thus, "Plilipl liliss." Early in life he separated the final p from his Christian name, constituted it a capital I', ant thus produced "P. P. IBliss."

Blow, John, sail to have been born at North Collinglam, Notts, ${ }_{1} 6_{4} 8$. The recorls of that parish, however, do not contain any entries in support of this statement, and a MS. in 
the Bodleian Library, containing an account of his life, by Anthony à Wood, has the following note: 'Dr. Rogers toll me that Blow was born in Lonilon.' He was appointed a chorister in the Chapel Royal, I660; organist of Westminster $\Lambda$ bbey, 1669 to 1680, and again, in succession to Henry Purcell, I695I7o8; gentleman and master of the children of the Chapel Royal, I674; organist of the Chapel Royal, I676; almoner and master of the choristers of St. Paul's Catheclral, London, I678-1693; received the degree of Mus: Doc. from the Archbishop of Canterbury about 1680; composer to the Chapel Royal, I699; died in London, October I, I708; buried in the north choir aisle of Westminster Abbey, October 8.

Booth, Josiah, born at Coventry, March 27, $185^{2}$; stullied under Edwards Sims, Coventry; Ur. James Taylor, Oxford; and later, at the Royal Academy of Music under Brinley Richards and Professor G. A. Macfarren; appointed organist at Banbury, 1867, and since 1877 has been organist and choirmaster at Park Chapel, Crouch End, London.

Bortnianski, Dimitri, was born in $175^{1}$ or $175^{2}$ at Gloukow in the Ukraine. He became a chorister in the Imperial Chapel at St. Petersburg, and there he studied music under Galuppi. In I 768 he removed to Italy to pursue his studies. Shortly after his return to Russia (in 1779 ) he was appointed director of the Imperial Choir at St. Petersburg, where he died. The date of his death is given by some authorities as October 8 , r 825 , by others, October 28,1828 . He was a distinguished composer of sacred music, and has been styled by some the Russian Palestrina.

Boyce, William, born in London, r7 ro. As a chorister of St. Paul's Cathedral he received his first instruction in music from Charles King, and afterwards became an articled pupil of Dr. Maurice Greene. In 1734 he became organist of Oxford Chapel, Vere Street, London; in 1736 organist of St. Michael's, Cornhill, and one of the composers and joint organists to the Chapel Royal; and in 1749 organist of All-1Iallows, Thames Street. In the same year he received the degrees of Bachelor and Doctor in Music from the University of Cambridge. 
He died February 7, I779, and was buried in St. Paul's Cathedral. Charles Wesley wrote a hymn on his death beginning 'Father of heroes, farewell.'

Bradbury, William Batchelder, was born at York, Maine, U.S.A., January 16,1816 . In 1830 he went to Boston and became an organist; and in 1836 he settled at New York as a teacher. In 1847 he studied under Hauptmann and others at Leipzig. He died at Montclair, New Jersey, January $\tau$, I 868.

Bridge, Sir John Frederick, born at Oldbury, Worcestershire, December 5, 1844; chorister at Rochester Cathedral under John L. Hopkins and John IIopkins, successive organints there; pupil of Sir John Goss and Sir George Elvey; organist of a parish church in Kent, I 862 to I $86_{5}$; Trinity Chureh, Windsor, 1865 to 1869 ; Mus. Iac., (Ixford, 1868 ; organist and master of the children, Manchester Cathedral, I869 to 1875 : Mus. Doc., Oxford, I874; deputy organist and master of the chililren, Westminster Abbey, I 875 ; promoted to the full offices on the death of Janes Turle, ISS2. For the celebration of the Queen's Jubilee in Westminster Abbey (June 2I, I887) he arranged all the music ant composed a special anthem, for which he receivel the thanks of Her Majesty and the Silver Jubilee Merlal. Elected (irreham Professor of Music in stucession to Dr. Henry Wylle, May I, ISgo; received the honour of knighthood from IIer MLajesty in I897.

Broomfield, William Robert, son of Mr. William liroomfield, painter and decorator, Inveraray, Argy leshire ; horn at Inveraray, October 14, 1826; baptized Xorember 22; sturlien music under John Turnbull at (ilasgow, where he resilen for some time; settled in Aberdeen about $\mathbf{8} 85$, and died there Octoler I 7 , I 888 ; buried in the 'strangers ground,' but reinterred in Allanvale Cemetery, July is 89 .

Brown, Arthur Henry, born at lirentwool, Essex, July 24, I830; organist of the Church of St. Thomas the Martyr, Brentwood, $188_{2}$ to 1853 ; of the Church of St. Elward the 
Confessor, Romford, Essex, till 1858 ; and since that time again organist of Brentwood and a professor of music there; organist also of St. Peter's Church, South Weald.

Brown-Borthwick, Rev. Robert, son of Mr. Robert Brown, of H.M. Civil Service; born at Aberdeen, May 18, I 840 ; educated at St. Mary's Hall, Oxford, which he left without graduating; afterwards, in $186_{5}$, took Holy Orders ; curate of Sudeley Manor, Gloucestershire, and chaplain to the Winchcomb Union; curatc of Evesham, Worcestershire, and assistant minister of Quebec Chapel, London ; incumbent of Holy Trinity, Grange-in-Borrowdale, Cumberland, r 869 to I872, when he became vicar of All Saints', Scarborough ; vicar of St. John's, Clapham, London; died March 17, 1894. Compiler of the Supplemental Hymn and Tune Book, which was contributed to by Goss, Sullivan, Stainer, E. J. Hopkins, and J. B. Calkin. Mr. Brown assumed the additional name of Borthwick in 1868 , on his marriage with Grace (died I 884), the only surviving daughter of the late Mr. John Borthwick of Borthwick Castle.

Bryan, Cornelius, is said to have been born at Bristol about the year 1775, but all attempts to find the exact year of his birth have proved unsuccessful. He became organist of St. Mark's (the Mayor's Chapel), Bristol, and afterwards of St. Mary Redcliffe Church, both of which appointments he held at the same time. While conducting his operetta of 'Lundy' (never published) at the Theatre Royal, Bristol, he fell down a trap-door on the stage, which was not properly fastened, and so injured his spine that he died, March 18, 1840, a few days after the accident.

Bullinger, Rev. Ethelbert William, D.1), educated at King's College, London; deacon, 1861 ; priest, 1862 ; curate of Bermondsey, 186 I to 1863 ; Tittleshall, Norfolk, 1863 to 1866 ; St. John, Notting Hill, I867 to I 869 ; Leytenstone, I869 to I870; Walthamstow, I87 I to 1874 ; vicar of St. Stephen's, Walthamstow, 1875 to 1888 ; minister of Brunswick Chapel, London, I 89 I to $1894 ; 1)$. I. conferred on him by the Arehbishop of Canterbury, г88r. Dr. Bullinger studied music for 
seven years under I)r. W. II. Longhurst of Canterbury, and afterwards under Dr. John Hullah and Dr. W. H. Monk.

Bunnett, Edward, born at Shipdham, Xorfolk, June, 26, I 834 ; chorister in Norwich Catherlral under 1)r. Zechariah Buck, I 842 to I 849 ; assistant organist of Norwich Cathedral, I 855 to I877; Mus. Hac., Cambrilge, 1857 ; Mus. Ihe., I869; since I 877 organist of Sit. Peter's, Mancroft, Norwich.

Button, H. Elliot, born at Clevedon, Somerset, Iugust 8, I86r. His father was master of a private school, and exeollerl as an organist. Mr. Button is a self-tanght musician, and besides being solo alto at Iloly Trinity, Llper Chelsea, is a pianist, organint, and violinist. Ile edited the third series of the Bristol Tune Book.

Caldbeck, G. T., an anliteur: for some time a misionary in China.

Calkin, John Baptiste, born in I.onton, Mar'h I6, 1827; studierl under his fither; organist of St. Columbir Collecere, Ireland, from I 846 to 1853 ; wranist and choimaster of $1 \mathrm{~W}_{0}$ burn Clarpel, i 853 to a 857 ; organist and choimater of Camilen Roal Chapel, Iondon, I86 3 tı r 868 ; of St. Thomas's Chureh, Camilen Town, London, I 870 to $188_{+} ;$professon at the (inilihall sichool of Music and Cruyitun Conservatoire; member of conneil, Trinity College ; Fellow of the Collegre of (1) rentuints.

Callcott, William Hutchins, son of Joln Will Cilleott, Mus. 1)oe; born at Kensington (iravel Pit., Lonlon, Septemher 28, I807; stulienl music unler his brother-in-litw, Mr. William

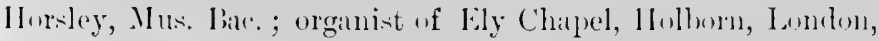
and afterwith, for sixteen years, of Rt. Barlublas's Church, Kensington; dienl dugrust 5,1882 and wis buried at Kensil Greell.

Camidge, Matthew, son of John Cimiluge the eliter; born at York, 1758; chorister of the Cliapel Royal under l)r. Nares; on returning to York became assistant to his father, on whose resignation in 1799 he was appointerl his sncessor as orentuist of York Catherlral, retiring October 8, $18+2$; died ()etober 23 , I $8+4$. 
Carter, Rev. Edmund Sardinson, M.A., born at New Malton, Yorkshire, February 3, 1845; edueated at Durham Grammar Sehool-elected 'King's Scholar,' I 858; and at Wroreester College, Oxford-elected 'Eaton Scholar,' ı 864 ; gracluated B.A. and M.A., June 1871. While resident at Oxford Mr. Carter was a keen athlete, and was a member of the Oxford University 'Eleven' in I866, I867; of the Oxford University 'Light' in 1867, 1868; of the Yorkshire County 'Eleven' at various times between 1865 and 1880 ; of the 'Eleven' of Victoria, Australia, in 1869 ; curate of Clirist Chureh, Ealing, Middlesex, I87 1 to 1875 ; vicar-choral of York Minster from 1875 ; rector of St. Martin-cum-Gregory, York, 1877 ; viear of St. Michaelle-Belfrey, York, I882; a self-tanght musician.

Champneys, Francis Henry, son of the Rev. William Wellon Champneys, canon residentiary of St. Paul's Cathedral and afterwards dean of Lichfield; born in London, March 25, I 848 ; educated at Winchester College and Brasenose College, Oxford, where he graduated M.A. and M.I., I875; Fellow of the Royal College of Physicians, London, I882 ; studied under Sir John Goss.

Chope, Rev. Richard Robert, born September 21, 1830; ellueated at Exeter College, Oxford, where he graduated in I855; took Holy Orders in 1856 ; vicar of St. Augustine's, Queen's Gate, Iondon, since $186 \mathbf{5}$. Mr. Chope has editel several books of ehurch music, the most important being the Congregational Hymn and Tune Book, 1857. To the second and mmeh enlarged elition of that work, published in 1862, many now well-known tunes were contributed by Dr. Dykes and other prominent musicians.

Clark, Jeremiah, born in London in 1670 or earlier; enteres the Chapel Royal as a chorister under Dr. Blow. After leaving the ehoir he became organist at Winchester College. In I693 his master, Dr. Blow, resigned in his favour the appointments of almoner and master of the ehildren of St. Paul's Cathedral. About 1695 he was appointed organist of St. Paul's, and in I 704 he became joint-organist of the Chapel Royal with 1)r. 
Croft. He 'shot himself at the Golden Cup in St. Paul's Churehyard,' December the Ist, I707, and was buried in St. Gregory's, by St. Paul's, December the 3 rrl.

Clark, Thomas, born at Canterbury in 1775 ; composer of hymn tunes, of which he issued above twenty sets in different forms; acted as learler of psalmonly at the Wesleyan Chureh, Canterbury, and afterwarls at the Unitarian Chureh; died at Canterbury, May 30, 1859 .

Cooke, Robert, son of Thenjamin Cooke, M[us. Doc.; sueceeted his father as organist of St. Martin's-in-the-Fields, London, 1793 ; succeded 1)r. Arnold as organist of Westminster Abhey, 1802. Ife trowner himself in consequence of a love aftuir, August 22, I81 4 , agod forty-six; buried with his father in the west cloisters of Westminster $\Lambda$ bbey.

Cooper, George, born in Lambeth, July 7, 1820 ; appointed organist of St. Benet, Paul's Wharf, London, and in 1836 of St. Ann and St. Agmes ; two years later assistant organist of st. Paul's Cathedral; on the death of his father in $18+3$ succeederl him at St. Sepulchre's; on the death of J. li. Sale in $185^{6}$ appointel organist of the Chapel Royal ; dien October 2, 1876 .

Cooper, Joseph Thomas, born in Lominn, May 25, 1819; received his musical edneation from William Henry Holmes of the Ruyal deulemy of II uice, and from Muscheles, then resirtent in England ; in 1837 appointed organist of St. Mir:hael's, Queenhithe, Lomdon; in I84t offered and accepted the post of organist of St. Paul's Churel, Islington, which oflice he helil till I866; appointerl organist of Christ's Hospital, London, 1876 ; anthor of numerous papers on hymnoly and rhureh music which appearen in Evening Hours, a periondinal then elited by the Rev. E. II. Bickersteth (late Bishop of Exeter); edited the Chant book supplenent to the IIymnal Companion, I87I, and a revised and enlarged edition of the II ymual Companion, 1877 ; died Norember 17,1879 .

Cottman, Arthur, son of George and sinsan Cottmin ; born I842; by profession a solicitor; died at Ealing, June 3, 1879 , aged thirty-seven years. 
Courteville, Raphael, was son of Raphael Courteville, one of the gentlemen of the Chapel Royal, who died December 28, 1675. The organ from the Chapel Royal was presented by Queen Mary in I69 I to the Church of St. James's, Westminster; and on September 7 of the same year (1691) a Raphael Courteville, who had been previously a chorister in the Chapel Royal, was appointed the first organist, at a salary of $E_{20}$ per annum and $E_{4}$ for a blower. 'It has been supposed,' says Mr. J. A. Fuller Maitland in the Dictionary of National Biography, 'that Courteville died in I735, and was succeeded by his son of the same name; but as the vestry minutes of the parish, in which all appointments, etc., are carefully recorded, contain no mention of such a change of organists, while no record of the father's death can be found, we are compelled to believe that the existence of the son is a mere assumption, made in order to account for the long tenure of the post by a person or persons of the name of Courteville. This conclusion is strengthened by various entries in the vestry minutes; in January $1752-53$, and again in Jume 1754 , letters are written to him warning him that unless he attended personally to the duties of the post he rould be dismissed. Whether he endeavoured to perform the duties himself after this we do not know, but he was certainly not dismissed; and shortly afterwards an assistant, "Mr. Richardson,"was appointerl. On June 12, 1771, it was reported to the vestry that Courteville gave this assistant only one quarter of his salary for cloing the whole work, and he was thereupon orlered to share the payment equally with Richardson.' Courteville died in June 1772.

Croft, William, son of Mr. IVilliam Croft; born at Nether Eatington, Warwickshire; baptized December 30,1678 ; chorister of the Chapel Royal under Dr. John Blow; generally believel to have been appointed first organist of St. Anne's Church, Solo, 1700, holling the oflice till I7II; but according to the IIistory of the I'arish of Soho, published in 1899 , the records of the chureh show that the Christian name of the organist named Croft was Philip, not William. The matter was more fully diseussed in an article on Croft in the Musical Times 
for September igoo, by the editor, Mr. F. G. Edwards. Croft was appointed a gentleman of the Chapel Royal in I;oo; joint-organist of the same along with . Jeremiah Clark in 1704, and sole organist on the death of the latter in 1707 ; organist of Westminster Abbey in $\mathrm{I}$;o8. He received the degree of Mus. Doe. from Oxford Lniversity in $\mathbf{y}^{7} \mathbf{3}$. He dierl at Bath, Augrust If, 1727, and was buried on August 23 , in the north aisle of Westminster Ibley.

Crosbie, Rev. Howard A., born of Senttish parentage at Liverpool, September $21,1 S_{+t}$; educited at a private school under the Rev. W. Clayton Greene, M.A., and at Trinity College, Cumbrilge, which he entered in $\mathbf{1} 86_{3}$, and became a Foundation sicholar in 1866 ; graduated IB... in 1867 , being 26th Wrangler in the Mathematical Tripos, and third class in the Theological Tripos: proeceled to M.A. three years later; ordained deacon, 1867 , and miest in the following year by the Bishop of Manchester (Bishop Jee); curate of IIabergham Gaves, Iurnley, Laneashire, from i 867 to $18_{75}$; of lirchin, Rilsholme, Manchester, May 1875 to Norember 1876 ; curate in charge of Hamber Bridge, near Preston, 1876 to Iugust I 878 ; vicar of Milnrow, near Rochdale, 1878 to 1883 ; jresented to Trumpington, Cambridge, 1885 ; since March I 89 I, viear of builth and perpetual eurate of Llanddewi'r-Cwm, both English-speaking parishes. Mr. Crosbie is an amateur musician, and has composed many hymn tunes well known in England.

Crotch, william, born at Norwich, July 5, I775; from early childhood celebrated for his musieal talent; in 1 ; 86 became assistant to Dr. Randall at King's and Trinity Colleges, Cambrilge; at fourteen years of age composed an oriturio, "The Captivity of Julah,' which was performed at Trinity Hall, Cambridge, in 1789 ; appointed organist of Christ Church, 1. xforl, in 1790 , aml in 1797 succeded 1)r. Philip Hayes as professol of musie there: graduated Mus. liae., ()xford, r79.4, and Mus. Joc., 1799; died suddenly at Taunton, December 29, $18+7$.

Darwall, Rev. John, born at Haughton, Staffordshire, where he was baptized, January 13, I731; received his education at 
Manchester School and at Brasenose College, Oxford, where he graduated in $175^{6}$; took Holy Orders, and in 1769 became vicar of Walsall, Staffordshire, where he died, December 18, r789.

Decius, Nicolaus, born at Hof in Voigtland, was first a monk and then prior of Steterburg, or Stettersburg, near Wolfenbiittel,

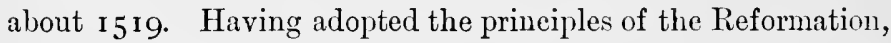
he left Steterburg in $\mathbf{5} \mathbf{2 2}$, and beeame a sehoolmaster at Brunswick. In the following year, $\mathrm{r}_{52} \mathbf{3}$, he went to Stettin, where he subsequently became Lutheran pastor of St. Nicholas's Church. He died at Stettin, March 2 I, 154I.

Doane, William Howard, born at Preston, New London, County Connecticut, February 3, I832; is the prineipal of the firm of A. J. Fay \& Co., manufaeturers of wood-working machinery in Cineinnati, Ohio; conductor of Norwich (Conn.) Harmonie Society; from 1862 to the present time Dr. Doane has published upwards of thirty collections of musie for cluurch and Sunday sehool; degree of Mus. Doe. conferred on him by Denison University, Ohio, 1875.

Dougall, Neil, son of Neil Dougall and Jean Moir, was born at Greenock, December 9, 1776 . His father (a wright by trade) was impressed into the service of his eountry, and died in the island of Ceylon, when Neil, the subject of the present notice, was about four years of age. He (Neil) afterwards removed to Cartsdyke with his mother, living in a small property which was now inherited by him. He was kept regularly at sehool till he was fifteen years of age. Fond of boating and the sea, like most boys brought up in a seaport town, he determined to be a sailor, and in r79I was bound an apprentice on board the ship Britannia. After three years of a seafaring life, he was the victim of an unfortunate gun aceident, by which he lost his eyesight and his right arm. In 1798 he was urged by friends to attend a singing-class taught by Mr. Robert Dunean, precentor of the East Parish Church, Greenock. He objected, thinking people would laugh at one of his age joining a singingclass; but a friend offering to aceompany him, he consented. So rapid was his progress in the study of music under Mr. Dumean, that in the autumn of $\mathbf{I} 799$ his friends urged him to 
open a singing-class, which he held annually till 1844, when he was compelled by infirmity, and especially the failure of his voice, to give up teaching altogether. In r8oo he gave his first public concert, and continued to give a concert annually until the year i 860. Ife died at Greenock, October I, I862.

Drese, Adam, born in 'Thuringia, I)ecember I620; studied music at Warsaw uncler Mareo Scachi; music director at Weimar from 1655 ; afterwards held similar appointments to the Duke of Iirunswick, and at Arnstadt, where he died, February 15, г7ог. The following is the entry regarding Drese's death in the church records of Arnstadt:- 'Den i 5 Febr. r 7or, Abenils um zehn thr ist in Cott.selig entschlafen Herr Ailam Drese . . Alter 8o Jahre 2 Monate.' ( ()$_{n}$ the 15th Febr. r7or, at ten o'clock in the evening, IIerr Alam Drese fell asleep in God . . . age 80 years 2 months.)

Dretzel, Cornelius Heinrich, born at Niimberg in 1698 ; in I7 2 appointed organist of the Frauenkirche of that town; then organist successively in the churches of St. Egidius and St. Laurence, and finally in $176_{4}$ of St. Sebald's, which post he held till his death in 1775 . In $173 \mathrm{I}$ he editer an important Choral-buch containing 907 tunes, of which, accorling to Zahn, 197 were there printed for the first time, forty-three being his own composition.

Dupuis, Thomas Sanders, born in London, November 5, I730; son of John Dupuis, of a Huguenot refugee family settled in London; chorister in the Chapel Royal; organist and composer to the Chapel Royal, r779; graduated IIus. Bac. and Mus. Doc., Oxford, I 790 ; died in London, July I 7, 1796.

Dykes, Rev. John Bacchus, born at Kingston-upon-Hull, March Io, 1823; received his first musical tuition from Skelton, organist of St. John's, where his grandfather was incumbent; obtained a scholarship at St. Catherine's Hall, Cambridge, and during his stay there pursued his musical studies under Professor Walmisley, and became conductor of the University Musical Society ; graduated as B.A. in 1847 , and having taken Holy Orders in the same year, obtained the curacy of Malton, 
Yorkshire; in 1849 appointed minor canon and precentor of Durham Cathedral; in 1850 proceedel to the degree of M.A., and in $186 \mathrm{I}$ had conferred on him by the University of Durham the degree of Doctor of Miusic; in 1862 was presented by the Dean and Chapter to the vicarage of St. Oswald, Durham, on which he resigned the precentorship. During his whole life Dr. Dykes was enthusiastically devoted to the cause of Chureh music, having written altogether about three hundred hymn tunes. He contributed seven tunes to the first edition of Hymns Ancient and Modern, though at that time he was personally unknown to the editor and promoters of the book. In the compilation of the Appendix (1868) and the enlarged edition (1875) he took a very active and responsible part, and contributed himself thirty-two new tunes. He died at St. Leonard's-on-Sea, January 22, 1876.

Elliott, James William, born at Warwick, February I3, I833; chorister at Leamington Parish Church, I846 to 1848 ; pupil of Sir George Maefarren and others; organist of Leamington Episcopal Chapel (now Christ Church), I847 to 1852; organist of parish church, Banbury, 1860 to 1862; St. Mary, Boltons, Brompton, I 862 to I 864 ; All Saints', St. John's Wood, I 864 to I874; since then of St. Mark's Church, Hamilton Terrace. Mr. Elliott took an active share in the preparation of the musical edition of Church Hymns, I874, and has contributed to a large number of modern hymn books.

Elvey, Sir George Job, son of John Elvey and Abigail Hardiman; born at Canterbury, March 27, 1816, and baptized in the Presbyterian Chapel, Canterbury, April 14; educated at the Cathedral School there; graduated Mus. Bac., Oxford, I 838 ; Mus. Doc., r840 ; organist at St. George's Chapel, Windsor, from 1835 to 1882 ; knighted, 1871 ; died at the Towers, Windlesham, Surrey, December 9, ı 893 ; buried outside the west frout of St. George's Chapel, Wrindsor, December 14 .

Elvey, Stephen, elder brother of the preceding; born at Canterbury, June 27, 1805; chorister in Canterbury Cathedral under Highmore Skeats, senior; succeeded Alfred Bennett, 
Mrus. Bac., as organist of New College, Oxford, 1830 ; orcinist of the University Church, I 845 ; organist of St. John's Conlegre, 1846 ; choragus of the University, 1848 ; died at Oxford, October 6, is6o.

Ewing, Alexander, Lieutenant-Colonel, wnly on of Alexander Ewing, M.I., lecturer on surgery at IIarischal College, Aberleen, was born in the parish of Old Machar, Abertcen, January 3,1830 . Originally destined to be a writer to the Signet, he studied law at Marisehlal College, but having little inclination for the profession, he was allowed to abandon it and go to IIeidelberg ant study German aml muic. ILe entered the army in 1855 during the war in the Crinea, and after serving there and in South Australia, went to Chinil, where he took part in the campraigns of I 860 and I 862 . He returned to England in 1866 , and married in I867 Miss Juliana H. Catty, authoress of Jackinapes and other works. After several years of foreign service Colonel Ewing returned to kinglinul in $188_{3}$, and in 1889 he retired from the army with the rank of Lieutenant-Colonel. IIe died at Taunton, July i I, I895.

Faning, Eaton, born at Helston, Cornwall, May 20, 1850; received his primary music lessons from his parents; in 1870 entered the Royal Academy of Music, studying under sir W'. Sterndale Bennett, I)r. Charles Sterggall, and others; won the Mendelssoln Seholarship in 1873 , and three years later the Lueas melal for composition; associate of the Royal Acadeny of Music, 1877 ; professor, 1878 , and later a Fellow of that institution; graduatel Mus. Liac., C'ambridge, 1894, MIus. Doe., 1900. After holding various appointments at the Guildhall School of Music, Royal College of Iruse, and National Training School, he was ofiered and accepted in 1885 the position of director of the nusic at Ifarrow Sehool, in sucession to Mr. John Farmer. This position he still holds.

Farmer, John, nephew of Henry Farmer, it well-knuwn musician; born at Yottingham, August 16 , I8 36 ; stulied at Leipzig Conservatorium and under Andreas Splith at Coburg; for some years taught music at Zurich; from 1862 to $188_{5}$ music-master at llarrow School; since the hatter year he has 
been organist of Balliol College, Oxford; founded a musical society there, and has given concerts of an educational character.

Farrant, Richard, born about I530; one of the gentlemen of the Chapel Royal till $1_{564}$, and again from I $_{569}$ to ${ }_{5} 80$; master of choristers, St. George's Chapel, Windsor, 1564 to 1569 ; afterwards organist and lay vicar there; died at Windsor. November 30 , ${ }_{5} 8_{5}$.

Farrer, John Downing, born at Lowestoft, March 31, I829; son of Mr. John Farrer, a member of an old Lowestoft family; educated at Pottergate Street House Academy, Norwich, the principal being Mr. Charles Turner, afterwards mayor of the eity; an amateur musician. MIr. Farrer has written a large number of hymn tunes; a few of these were first published in aid of a 'Church Builking Fund,' and in $188_{5}$ he issued a complete collection under the title of 'The Lowestoft Supplemental Tune Book.'

Feilden, Rev. Oswald Mosley, M.A., youngest son of the Rev. Robert Mosley Feilden, rector of Bebbington, Cheshire ; born at Canterbury, September 16, 1837 ; educated at Eton and Christ Church, Oxford; graduated in 1859 ; ordained at St. Asaph, I86I ; curate of Whittington, Salop; and in 1865 appointed to the perpetual curacy of Welsh Frankton, Salop.

Felton, Rev. William, born I 715 ; graduated I.A., Oxford, I 733 ; M.A., 1736 ; vicar choral in Hereford Cathedral, I741 ; afterwards minor canon; vicar of Norton Canon, 175I; died December 6, г 769 .

Filitz, Friedrich, Ph. Doc., born at Arnstadt, in Thuringia, March 16 , 1804 . He studied philosophy, in which he received the degree of 1)octor; resided at Berlin from 1843 to 1847 , removing in the latter year to Munich, where he died, December 8,1876 . The date of his death has been given by some authorities as 1860 , but that the above is correct is shown by the following extract from the Royal Polizei-Uirection at Munich:-' Jr. Friedrich Filitz, man of letters, belonging to Arnstadt, died here at the age of seventy-two, on 8th December 1876 .' 
Flintoft, Rev. Luke, graduater as 13,A. at Queen's College, Cambrilge, in I 700 ; priest vicar at Lincoln Cathedral from 1704 till I7It; vicar in Worcester Cathedral alout 17I4; gentleman of the Chapel Royal, 17 I5 $^{5}$ rearler in the chapel at Whitehall, I7 19; minor canon of Westminster $A b$ bey ; liesl November 3 , I 727 , and was buried in the cloisters of 1 restminster Alhey:

Foster, Myles Birket, eldest sin of lirket Foster, the. (minent artist; born in Lomlun, November 29, I $85 \mathrm{I}$; pup il of IImilton Clarke, Sullivan, and I'rout ; mrganist of St. .Tames's, Marylebone, London, 1873; of St. Genger's, Campren Hill, I 875 : of the lowndling 1 Iopital, 1880 to 1894.

Frech, Johann Georg, son of Joham Mirhacl Frech, a watehmalier and orean lutilder; bern at Kialtenthal, near stuttgint, January 17, 1790. Ile herame ar:istant master of the sehool at Iearerlocll, near Stuttgant, when only sixtern years old. lle afterwarls studied musie under I. H. Knecht and other's ; in

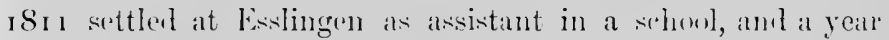

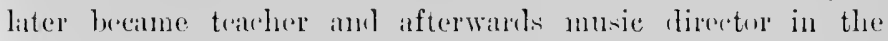
seminary, and organist of the chureh in that town. IIe died at Lis:lingen, 1 ugnist 23,1864 .

Freestone, William, burn at Nuttingham, November I9, 1853 ; studient the pianoforte unter Mrs. buwman, of the locil branch of llarrow dfusic sichool, and took lexsons in harmony ant on the urgan from Mr. Arthur J'agre, F.R.C.0.; assistant (nranist at St. Stephen's Parish Chureh, Sneinton (a suburl) of Nottingham), for nine year's afterwards organist ant choirmanter of St. Thomas's Church, Pear Tree, Derby; St. Augnstine's Cluurch, New Ibasfurd, Notts; amateur musician, and composer of several hymn tmes and chants; member of the firm of Freestone \& Armitage, merchants, Nottinghan.

Funcke, Friedrich, born at Yossen, in Saxny, in 1642; in $166+$ appointed cantor in the Juhanniskirche at Liineburg; and in 1694 pastor of Römstalt, near Lineburg ; dien Oetuber 20, 1699. IIe contributed ten liymns and forty-one tunes to the Luincburg Gesangbueh, 1686. 
Garratt, Charles A., an American musician. In 188I he was organist of Immanuel Chureh, Milwaukee, and subsequently went to Toronto, where he is believed to have diecl. Further particulars as to his career have not been obtainable.

Garrett, George Mursell, son of George Garrett, master of the choristers of Winchester Cathedral; born at Winchester, June 8, 1834 ; chorister in New College, Oxford, $18+4$ to 1848 ; assistant to Dr. S. S. Wesley at Winchester Cathedral, 1850 ; organist of Madras Cathedral, 1854; graduated Mus. Bac., Cambrilge, 1857 ; organist of St. John's College, Cambridge, 1857 ; to the University, 1873 ; lecturer on music to the University; graduated Mus. Doc., 1867; M.A., propter meritis, 1878; died April 9, 1897 .

Gauntlett, Henry John, born at Wellington, Shropshire, July 9, 1805; pupil of Henry Field and Samuel Wesley; organist of the parish church, Olney, Bucks (where his father was vicar), 1814, and also choirmaster, I819 to 1825 ; organist and choirmaster of St. Olave's, Southwark, 1827 to I 847 ; degree of Mus. Noc. conferred on him by Arehbishop of Canterbury, and appointed organist to the King of Hanover, I $8+2$; choirmaster (honorary), St. John's, Milton-next-(iravesend, 1844 to 1851 ; organist of Union Chapel, Islington, $18 \mathbf{5}^{2}$ to I86I ; All-Saints, Kensington Park, I86 I to 1863; St. Bartholomew the Less, Smithfield, 1872; died suldenly at Kensington, February 21, 1876.

Giardini, Felice de, an eminent violinist, was born at Turin, April 12, 1716; chorister at Milan Cathedral when a boy; pupil of Paladini in singing, composition, and the harpsichord; afterwards returned to Turin and studied the violin under Somis. In $175^{\circ}$ he made his first appearance in London as a violinist, creating a perfect furore; left England in 1784 to spend the rest of his life in Italy, but returnerl in I 790 , when he started a comic opera at the Haymarket, which proved a failure; afterwards went to Russia, and died at Moscow, December $17,1796$.

Gibbons, Christopher, son of Urlando Gibbons, was born 
1615 (baptized August 22); clorister in Exeter Cathedral; organist of Winehester Cathedral, ${ }_{1} 6_{3} 8$ to 1644 ; of Westminster Abbey, I66o to $166_{5}$; and of the Chapel Royal, I660 to 1676 ; Mus. Doc., Oxford, 1664; lieel Oetober 20, 16 6 6.

Gibbons, Orlando, born at Cambrilge in ${ }^{1583}$. It the age of twenty-one he was appointed organist of the Chapel lioyal, and in 1622 admitted a Doctor of Music at the Lniversity of Oxford. In 1623 he was appointed organist of Westminster Abbey, and two years liter was summoned to Cinterbury to attend the marriage of Charles i., for which he composed an ode and some instrumental music, and whilst there died, after a short illness, June 5, 1625, and was buried the following day in the Cathedral at Canterbury.

Gibson, Mrs. Patrick, nie Isabella Mary Sicott, laughter of William Scott, teacher of elocntion; born at Edinburerh about r786; in June I8IS married to Patrick (iibson, R.S.A. and writer on art; kept a boarding-school for young ladies in Inverleith Row, Edinburgh, and in ${ }_{1} 828$ ojened a similar establishment in Ibllar; a distinguished roealist and harpplayer; oceupied a ligh position in the literary and musical world, and was the associate of Lord lirougham, Sir Walter Seott (to whom she was distantly related), and other celebrities of her time; diel at Edinburgh, November 28, 1838 .

Gilbert, Walter Bond, son of Samuel Thomas Gilbert; born at Exeter, Devonshire, April 21, 1829; pupil of Alfred Angel, S. S. Wesley, and Sir Henry R. Wishop ; appointerl organist of Topsham Parish Church, I evonshire, 1847 ; Pirleford, 1849 ; of Tumbridge, I 854 ; Maiditone, I859; Lee, Kent, I866; buston, Lineolnshire, 1868 ; from 1869 to 1897 organist of Trinity Chapel, New York; graduated Mus. Bac., Oxford, I 854 ; degree of Mus. Doe. conferred on him by the University of 'Trinity College, Toronto, Canada, 1886, and by Oxford University, I 888.

Giornovichi, Giovanni Marie, an eminent violinist; born at Jalermo in I745; pupil of Lolli; mate his début in Paris in I770, and for some years was all the rage in that eity; on account of an affair of honour he was, however, forced to quit 
Paris, and went in 1779 to Warsaw, St. Petersburg, and Stockholm, meeting everywhere with success ; came to London in I79I, giving his first concert in May of that year; visited Scotland in 1797 ; diech at St. Petershurg, it is saicl, during a game of billiarls, November 21,1804 .

Goodenough, Rev. Robert Philip, son of the Right Rev. Samuel Goodenough, bishop of Carlisle; born at Ealing, Middlesex, October 19, I775; baptized November I6; studied at Westminster School and Christ Church, Oxford ; graluated 13.A., Oxford, I796; M.A., I799; prebendary of Sonthwell, I806; Carlisle, I8II; Ripon and York; viear of Carlton-inLyndriek, Nottinghamshire, I8o6, and later rector of Deelsby, Lincolnshire ; died April 20, 1826.

Goss, Sir John, born at Fareham, Hants, Necember 27, I 800 ; son of Joseph Goss, organist of that place; chorister in Chapel Royal under John Stafford Smith, I8I I ; afterwards a pupil of Thomas Attwood; organist of St. Luke's, Chelsea, I824; organist of St. Paul's Cathedral, 1838 , in succession to Thomas Attwood ; resigned in 1872 , and received the honour of knighthood; composer to the Chapel Royal, 1856 to 1872 ; Mus. Doc., Cambridge, 1876 ; died at Brixton, London, May I0, I880.

Gounod, Charles François, born in Paris, June 17, 1818; entered the Conservatoire in $8_{3} 6$, studying under Halévy and others, gaining the 'Grand I'rix de Rome' in 1839. After spenting some years in Italy and Germany, he returned to Paris, where he spent the remainder of his life, with the exception of the years 1870 to 1875 , when he resided in England. He was elected a member of the 'Institut de France' in 1866. He died at St. Clouk, October 17, 1893 .

Grant, David, born at $A$ berdeen, September 19, 1833; educated at a public school; studied music under Herr Granz at $A$ berdeen; for twenty-five years carried on business there as a tobacco merchant, retiring in 1878 . He took a warm interest in the progress of music in Aberdeen; was a member of the choir of Footdee Parish Church, and composed several psalm 
and hymn tunes. He lived latterly in London ; died in August I893, and was buried in Lewisham Cemetery.

Gregor, Rev. Christian, son of Georg (iregror, a peisant, living in Dirstorf, near Peilaw, Silesia; bom at Jirsdorf, January I, I723. When nineteen years of age he went to Hermhut, where he earned his living by teaching. Shilled as a musician, he became conductor of music in the congregation of the Moravian lirethren in 1748 , and in 1749 at \%eist; returned to Hermhut in 1753 , on becoming cashier to the Brethren's Board of Direction; in 1756 ordained deacon, in 1767 presbyter, and in I 789 bishop of the Jirethren's Chureh; while returning from a meeting of the board of Direction at Hermhut on November 6, 180I, he was struek with paralysis, and died the same dily. Gregor wrote some excellent hymms, which appeared in the Gesangbuch zum Gebrauch der evangelischen Bruler-Gemeinen, 1778 , of which he was the principal editor. IIe further edited in $\tau S_{4}$ a Choralbuch containing tunes for the above-named hymn buok, and contributed thereto severil of his own composition.

Grigg. This composer, whose biography is obscure, (ontributerl three tunes to the Rev. John Rippon's collection, issued about 1795 .

Hamerton, Rev. Samuel Collingwood, born I 833 ; erlucaterl at University College, Oxforl, where he graduaterl 13,A. in I856; incumbent of St. I'aul's, Warwick, from 1866; diel there January 6, i 872.

Hanby, Rev. Benjamin Russell, Imerican divine and amateur composer ; born, 1833 ; died, 1867.

Hancock, Charles, born at Islington, London, January 4 , 852 ; in 1859 becime a choir boy of St. Michael's Chureh, Cornhill, under Richard Limpus; three years later elected a ehorister of St. Cieorge's Chapel, Winilsor, under Sir George Job Elvey, Mus. Doc.; sang at the funeral of the P'rince Consort in I86I; afterwards took part either as chorister or organist in five Royal werlings-those of the l'rince of Wales, Princess Christin, Princess Lonise, the lluke of Con- 
naught, and the Duke of Albany; on the breaking of his voice became an articled pupil of Sir George Elvey; took the Fellow of the Royal College of Organists diploma in 1872 ; graduated Mus. Bac., Oxford, I874; in 1875 appointed to his present post of organist of St. Martin's, Leicester.

Handel, George Frederick, son of George Ilandel, surgeon; born at Halle, in Saxony, February 23, I685; studied under Zachau, cathedral organist at Halle; went to Italy in I7o6; on his return to Germany in 1709 appointed Capellmeister to the Elector of Hanover (afterwards George r.); visited England shortly thereafter, and finally settled in this comntry in I7 12. He died on April 14, I759, and was buried in the south transept of Westminster Abbey.

Harington, Henry, M.D., son of Henry Harington and Mary Backwell, born September 29, I727. It is an accepted tradition that his birth took place at Kelston, Somersetshire, the estate which his father inherited in 1726 , but the records of the parish contain no eutry of the event. The above date is that inscribed on his monument in Bath Abbey. He entered Queen's College, Oxford, December 16 , r 745, and matriculated at the University on the following day; graduated B.A., July 8, I749 (not I748, as stated by some), and proceeded M.A., June 4, $175^{2}$; Bachelor and Doctor of Medicine, July 2, I 762 ; established himself as a physician at Wells in I753; settled at Bath in I77I, and was elected Nayor in I793; founded the Harmonic Society there; devoted his leisure time to the composition of glees, catches, songs, ete. ; died January I5, 18I6; buried at Kelston, January 23.

Harrison, Rev. Ralph, a member of a family noted in the history of Nonconformity; descended from the Rev. Cuthbert Harrison, who was ejected from Lurgan, in Ireland, in I662; born September Io, I748, at Chiuley, Derbyshire, where his father, the Rev. William IIarrison, was for upwards of twentyseven years minister of a rural chapel; educated at Warrington Academy; appointed assistant minister of the Presbyterian Chapel, Iligh Street, Shrewsbury, I769; minister of Cross Street Chapel, Manchester, from r77 I till he died, November 
4, I81o; classical tutor in Manchester Acalemy; distinguished as a teacher of ancient languages; a musical amateur and composer. IIe published an English (irammar and other works, and was the compiler of Sacrel IIarmony, or a Collection of I'sahn Tunes, Ancient anul Morlern, ete., 2 vols., I $78_{+}-91$.

Hartmann, Emil, son of Johann Peter Emil IIartmann, one of the most distinguished of Danish composers ; horn at Copenhagen, February $21,{ }_{18} 6$; pupil of his father and of Niels IVilhem (xarle, his brother-in-law; appointed organist of a chureh at Copenhagen in 1861 , ancl court organist in 187 ; owing to failing liealth he gave up these appointments and removed to Sullerïl, near Copenhagen, devoting himself to composition. He lied in 1899 .

Hassler, Hans Leo, son of Isaac 1[assler, a musician; born at Nimberg, 1564 ; in 1584 pupil of Antrea (iabrieli, then organist of the Cathedral of St. Mark, Tenice; in 1585 became organist to Count Fugger in Augsburg, and in 1601 organist of the Franenkirche in Niimbers. $11 n$ i6o8 he enterel the service of the Elector Joham Georg of Sixony, and in 1612 accompanied to the 1)iet at Frankfort. He died there June 8, 1612.

Hately, Thomas Legerwood, horn at (ireenlaw, lierwickshire, September 26, 1815; alprenticel when a boy to Messrs. Ballantyne $\&$ Co., printers, Ellinburgh, with whom he remained eleven years; afterwarls enterel the employment of the Messrs. Constable; a self-taunht musician; member of Ii. A. Smith's choir, St. George's, linlinburgh; apjointed precentor of Sorth I.eith Parish Chureh, 1836 ; of st. Mary's Church, Edinburgh, Jecember $1 \mathrm{I}, 18_{3} 8$, but resigned at the Ilisruption in $18+3$. IIe had the listinetion of being one of the few precentors in binhurgh who eame out with the Free Church at that time. He lel the singing at the first General Assembly of the Free Church at Tanfield, anl in D. O. Hill's picture of that famous Assembly, Hately's portrait holls a prominent place. Afterwards appointed precentor to the Free Chureh Assembly; aceepted in 1850 the precentorship of the Free IIigh Church, 
Elinburgh, then under the pastorate of the Rev. Dr. Gordon. About the same time he devoted himself almost entirely to the teaching of psalmody and conducting classes throughout the country; and not only in this way but also by the training of teachers he gave the first great impulse during the nineteenth century to the eultivation of Church music in Scotland. He edited The National Psalmody and other works; died at Edinburgh, March 22, 1867.

Hately, Walter, son of the preceding, born at Edinburgh, January 29, I843; educated at the High School, Edinburgh; studied music at Leipzig Conservatorium under Plaidy, Moscheles, Reinecke, Hauptman, Richter, and Dreyschock, $186 \mathrm{r}$ to 1864 ; teacher of music in Edinburgh since $186_{\mathbf{5}}$; first publie appearance as pianist at Edinburgh, January 1867; choirmaster in Free High Church in suecession to his father, from 1867 to 187 I ; choirmaster of Free St. George's Church, Edinburgh, from 1885 to 1898 .

Hatton, John, born at Warrington; afterwards resided in Duke Street, St. Helens, in the township of Windle; died I793; his funeral sermon was preached at the Presbyterian Chapel, St. Helens, December i 3 .

Havergal, Frances Ridley, youngest daughter of the Rev. William Henry IIavergal ; born at $\Lambda$ stley Rectory, Worcestershire, December I4, I836; studied music under William Marshall, Mus. Doc., and Alberto Randegger; died at Caswell Bay, Swansea, June 3, I879.

Havergal, Rev. William Henry, born at High Wycombe, Buckinghamshire, January I8, I793; baptized February I5; edueated at St. Elmund's Hall, Oxford, where he graduated in

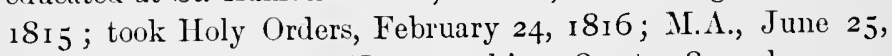
I819; rector of $A$ stley, Worcestershire, I829 to I 842 ; honorary canon, Worcester Cathedral, 1845 ; reetor of St. Nicholas, Worcester, 1845 to 1860 , when he resigned; rector of Shareshill, from 1860 to 1868 ; died at Leamington, April I9, r87o. He published a reprint of Ravenscroft's Psalter in I 844 , and three years later issued the Old Church Psalmody, which 
reached the fifth edition in $1864 ; A$ History of the Uld Humelerlth Paalm Tune with Speeimens, in 1854 ; and in r859, A Huntred l'salm and Hymu Tumes of his own composition.

Haydn, Franz Joseph, elilest son of Matthias Iaydn, a wheelwright; born at Rohrau, a village in Lower Austria, Nareh 31, 1732; was a chorister in St. Stephen's Catherlral, Vienna, till his eighteenth year; after whieh he devoted himself to sturly and teaching in that eity. In 1760 he enteren the service of I'rince Esterhay. After the prince's deatl, Inayln twire visitel kingland. Ile died at Gumpentorf, near Vienna, on May $3 \mathrm{r}$, sog.

Haydn, Johann Michael, younger brother of Joseph IIaydn; born at Rohran, September 14, 1737; in 1757 lirector of musie to the bishop of Cirosswardein; in 1762 directur of the orehestra at salzburg, where he died, August ı, ı Soб.

Hayes, William, son of John Hilyes: horn at Hanbury, Worcestershire; baptized lecember 12, 1706; chorister in Gloucester Cathedral unler William Inine; organist of St. Mary's, Shrewsury, from 1729 to 1731 ; of Worcester Cathedral, 1731 to 1734 ; of Magrlalen College, Oxforl, 1734 to 1777 ; Mus. biac., $1 \times x$ ford, I735; luofessor of music in (xforl Lniversity, r $7+1$; Mus. loc., ()xford, I779; lied at Oxford, July 27,1777 ; buried in the ehurehyarl of st. I'eter'sin-the-Eist, ()xford.

Hayne, Rev. Leighton George, son of the liev. Richand Hayne, J).D., rector of Mistley, Escex: born at Sit. Darid's IIill, Exeter, February 28, $18_{3} 6$; erlucated at Eton and Queen's College, Oxfurd ; gridluated Mus. liac., i 856; Mus. lhe., I860; twok Ifoly ()rilers in I86r ; appointed 'Coryphrus'-conductor' of the elorus-of the Lniversity in 1863 , and puhlic examiner in the Schuol of Music; succentor and organist of Eton College, I868; rector of Mistley, and viear of Bradfield, Esicx, 1871 ; died at liralfield, March 3, 1883.

Haynes, Walter Battison, born at Kempsey, near Woreester, 
November 21, I859; edueated at IIanley Castle Grammar School ; received his early instruction in music from his uncle, William IIayues, organist of Malvern Priory; ehorister in the Priory Church, and acted frequently as deputy organist; studied under Mr. Franklin Taylor, Professor Prout, also at Leipzig Conservatorium under Dr. Carl Reinecke, Dr. S. Jadassohn, and others ; awarded the Mozart Scholarship, and on leaving the Conservatorium received the highest certificate given to a pupil ; after a short residence in France, returned to London; appointed organist of St. I'hilip's Church, Upper Sydenham; professor of harmony and composition at the Royal Academy of Music; organist and ehoirmaster, Chapel Royal, Savoy, I89I ; died February 4, I900; buried in Malvern Cemetery.

Herman, Nicolaus, was from $\mathrm{y}_{\mathbf{1}} \mathrm{I}$ precentor and schoolmaster at Joachimsthal, in the north of Bohemia ; retired about 1548 , and devoted himself to writing hymns, which he set to music and published in 1560 ; died May 5, 1561 .

Hervey, Rev. Frederick Alfred John, B.A. Cantab., I868; M.A., I872; took Holy Orders, I869; curate of I'utney, I869; domestic chaplain to Baroness North, 1873 ; rector of Upton Kyne, Devon, I876; rector of Sandringham with West Newton, Babingley, and Appleton, Norfolk, i 878; domestic chaplain to H.R.H. the Prince of Wales, 1876 ; chaplain in ordinary to Her Majesty the Queen, I886.

Hewlett, Thomas, Mus. Bac., son of Mr. Thomas Hewlett of Oxford; born at Oxford, Mareh I6, I845; pupil of the Rev. L. G. Hayne, Mus. Doc.; graduated as IBachelor in Music at the University of Oxford in 1859; organist of the Duke of Buccleuch's Chapel at Dalkeith from 1865 to $187 \mathrm{I}$, and for eighteen months of 1868 and 1869 of St. Peter's Episcopal Church, Elinburgh, the duties of the morning service being lerformed by a deputy ; of St. Mary's Roman Catholie Chureli, liroughton Street, Edinburgh, for some time; of Newington I'arish Church, Edinburgh, from November 1873 till he died, $\Lambda_{\mathrm{p}}$ ril 10, 1874; buried in Newington Cemetery, where a monument was erected to his memory by the members of the 
Ldinburgh Choral Union, 'in acknowledgment of his musical talent and his great ability as orgmist of that Society.'

Hews, George, born in Massachusetts, Inited States of America, in ISo6; was a manufacturer of pianofortes, and an organist in lioston; died fuly 6, I873.

Hintze, Jakob, born at liernan, in l'russia, September $t$, 1622 ; vecupied a musical presition in the Court at lierlin; acterl as musical editor of sereral entitions of Crigger's l'mais l'ietatis Meliea; diel at lierlin, \Iay 5, 1702.

Hollingworth, William, soll of $\mathrm{Mr}$. Juhn IIollingworth, an able amateur musieian; born at liradford, lorkshire, March 29, ISto ; pupil of his father; conductor of church choirs, slee societies, instrumental bands, ete.; has composed and published three hundred and three original peah and hymn tumes.

Hopkins, Edward John, born at Westminster, London, June 30, 18 18; chorister in the Chapel linyal nnter Willian Hawes from 1826 to 1833 ; pupil of T. F. Walmisley; orginist of Yitcham J'triwh Clumel, Surrey, is $8_{3}+$ to $18_{3} 8$; St. Peter's, Islington, 1838 to $18+1$; St. Luke's, Berwiek Street, London, I $S_{4}$ r to $18+3$; of the Temple Church, Londen, from is $S_{43}$ to January 1898; Mus. Hoc. Cantuar, 1882; died February 4 , 1901.

Horsley, William, horn in London, Xovember i5, I77t; pupil of Dr. Calleutt and other's ; assistant "rganist at A.ylum for Female Orphans, I798; organint, ISoz; grimluated Mus.

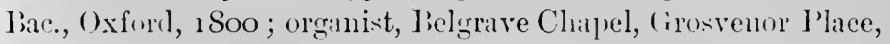
I8ı ; Charterhonse, I 837 ; died in Londent, June 12, 1858 .

Howard, Samuel, horn in London, 1710 ; chorister in the Chapel Ruyal under Ir. William Croft; stulied under Dr. Pepusclı; organist of sit. Clement I hanes, and st. liridget's, Fleet Street, London: Mns. 1)re, Canbringere, 1769; diect in London, July i $3,-1782$.

Hullah, John Pyke, born at Worcester, June 27, I8I2; pupil of William Iforsley; student at the Royal Academy of Music from September $18_{33}$ to December $18_{35}$; first appeared before the public as eomposer of an opera "The Village 
Coquettes,' the book of which was written by Charles Dickens, then scarcely known to fame; was professor of harmony at King's College, London, and other elucational establishments; inspector of music in Training Colleges from 1872 to 1882 ; degree of LL.D. conferred on him by the University of Edinburgh, 1876 ; elected an honorary member of the St. Cecilia Academy at Rome, 1877 ; died in London, February 21, 1884. Hullah was an ardent adrocate of Wilhem's method of teaching to sing-the fixed Don-and he adapted it to kinglish use. His elasses held at lixeter and St. Martin's Halls between the years 1841 and $185^{\circ}$ were attended by thousands.

Humfrey, Pelham, born I647; one of the children of the Chapel Royal, 1660-1664; pupil of J. 13. Lully, at Paris; gentleman of the Chapel Royal, 1667 ; master of the children of the Chapel Royal in succession to Captain Cooke, 1672; died at Windsor, July 14, 1674; buried in the cloisters of Westminster Abbey.

Hurst, William, born at Leicester, December 3, I849; an amateur musician; studied for several years under J. T. Stone, the well-known organist and arranger.

Hutton, Laura Josephine, amateur musician and composer; born at Spridlington, Lincolnshire, July I $7,185^{2}$; died June 17, 1888. Miss Hutton passed a quiet and uneventful life, chiefly as the devoted fellow-worker of her brother, the Rev. Vernon Wollaston Hutton, vicar of Sneinton, Nottingham, and prebendary of Lincoln Cathedral ; and after his death she edited his Corn of Wheat, a well-known devotional work.

Irons, Herbert Stephen, son of Mr. John Irons, and nephew of Sir George Job Elvey, Mus. Doc.; born at Canterbury, January 19, 1834; chorister at Canterbury Cathedral from 1844 to 1849 ; pupil and assistant of Dr. Stephen Elvey at Oxford; precentor and master of the chorister's, st. Columba College, Ireland, $185^{6}$ to 1857 ; organist and master of the choristers, Sonthwell Minster, Notts, 1857 to 1872 ; assistant organist, Chester Cathedral, 1873 to 1875 ; since 1876 organist of St. Andrew's Cliurch, Nottingham. 
Isaac, Heinrich, born in Germany about the midlle of the fifteenth century. He was chapel-master of the Cluurch of St. Giovanni, at Florence, about 1488 , and entered the service of the Emperor Maximilian $I$. as director of the choir about 1510 . The date of his death is uncertinin.

Jackson, Robert, son of Thumas Jackison, organist: hom at Ollham, May isfo; stmlied at the Royal Aeademy of Musie, London ; organist at St. Mark's Church, North Andley Sitreet, Grosvenor Square, London, and at St. I'eter's Churel, Ollham ; has held the latter alpointment for more than thirty rears, succeeling lis father, who was organist for nearly fifty years; memliel for some time of IIallé's orchestrai.

Jackson, Thomas, born about I $_{75}$; was urranist of Sit. Mary Magdalen l'arish Chmrel, and master of the Song School, Newark-on-Trent, in succession to John Aleock, jun., 1768; died November I I, I 7 I ; burienl in the chureh.

Jenner, Rev. Henry Lascelles, 1).H., son of sir Herbert Jenner (afterwarts Jenner-Fust); born at Chislehurst, Kont, I 820 ; educated at IIarrow School, and at Trinity IIall, Cambrilge; tuok IIoly Orters in $18+3$; vicar of I'reston, near Sandwich, Lent, 1854 ; consecrated the first lishop of Ihunedin, New Zealand, in 1866 , but returned to his living at Ireston in 1870 , and resigned his bishopric the following year ; lied suddenly at I'reston Vicarage, Wingham, September I8, 1898 .

Jones, Rev. William, bom at Lowick, Northamptomshire, July 30, 1726; educated at the Charterhouse, ant at Lniversity College, (Ixford, where he graduated, I $7+9$; took IIoly Orders, and in $15 \sigma_{+}$became vicar of IBethersden, Kent, and afterwards rector of Pluckley, a pust lie afterwards exchanged for the rectory of Paston, Northamptronshire; in r798 became rector of IIollingbourne, Kent; appointed perpetual curate of Naylanul, Suffolk, ahout 1776 ; diel February 6, 1800.

Joseph (or Josephi), Georg, a nusician in the establishment of the l'rince-Bishop of Breslau, in the midclle of the seventeenth century. He wrote a large number of melodies for the 
hymns of Johann Scheffler (Angelus Silesius), which are published in Scheffler's Heilige Seelenlust oder Geistliche IFirtenlieder, Breslau, 1657 , in three books. They contained 123 tunes, of which 107 are by Joseph. A fourth book was soon afterwards added, with 32 tumes, of which 30 are by Joseph. The.work appeared in a complete form in 1668 , with a fifth part, containing 48 tunes by Joseph and 2 by other composers.

Kelway, Thomas, born about 1695 ; organist of Chichester Cathedral, 1720; died May 21, 1749; buried in the south aisle of Chichester Cathedral.

King, Alfred, son of Mr. William King; born at Shelly, Essex, April 24, 1837; educated for the Church, but turned his attention to music; appointed organist at Cuddesdon Theological College, 1856 ; organist and choirmaster at Eastnor, Ledbury, 1857 to 1864 , at St. Michael's and All Angels', Brighton, 1865 to 1877 ; from 1877 to 1887 organist of the larish chureh, Brighton; Fellow of the College of Organists, I 868 ; graduated Mus. Bac., Oxford, 1872 ; Mus. Doc., October I888; since I 878 organist to the Brighton Corporation; conductor of Kuhe's Festival Chorus, and lecturer on harmony at the School of Science and Art.

Knapp, William, born at Wareham in 1698 or 1699 -the exact date cannot be given, as the records of the parish were destroyed by fire in 1762 ; said to have been organist of one of the churches of Wareham, but this wants confirmation; became parish clerk of St. James's Church, Poole, and held the office for thirty-nine years; died at Poole in 1768 , and buried September 26, 'somewhere near the old town wall.'

Knecht, Justin Heinrich, born September 30, 1752, at Biberach, in Wiirtemberg; studied music under Krämer, organist of the Roman Catholic Church at Biberach, and afterwards, from I768 to I77I, under Sehmidt, director of the music at the Collegiate Chureh at Esslingen; appointed director of the music at Biberach, and in 1807 Hofkapellmeister at Stuttgart, but, owing to intrigues, the post became 
distasteful to him, and two years later he returned to Isiberarh, where he remained till his death, December I, is 8 . In I 799 he elited, along with .J. F. Christmann, the Wiirtembers Choralbuch, and contributed to it ninety-seren tunes of his own composition.

Kocher, Conrad, born at Ditzingen, December 16,1786 ; studied the pianoforte at St. P'etersburg under Klengel and Berger, and composition under .J. II. Milller. In 1819 he travelled to Italy for the purpose of studying chureh music, and on his return fommled a church ehoral society at Stuttgart; from ${ }_{1} S_{27}$ to ${ }_{1} S_{5}$ organist of the Stiftskirehe at Situttgart ; receiver the legree of I'h.T. from Tibingen Lniversity in $1 S_{52}$. In $1 S_{5}+\mathbf{5 5}$ he published a large collection of ehorales under the title of 'Zionsharfe' Je died at Stuttgart, March 12, 1872.

Lahee, Henry, born at Cheleca, April I I, i 826 ; organist of IIoly Trinity Church, Iirompton, $18+7$ to $187+$; latterly resident at Croylon, Surrey. He compiled a collection of : One Humberl Hymn Tumes' for use along with a hymn book, which was edited hy l)r. W. J. Irons, the ineumbent of Brompton.

Lamb, Rev. James, son of Ilr. James Lamb; horn at I)ovecotlani, Perth, Norember I7, 1835 ; edueated in the Perth sehouls and at Edinburgh Lniversity, where he studied music: under Profesior I)onaldson; ordained minister of Old Kilpatrick Lnited Presbyterian Chureh, February 5, is67, where lie still is; member of the Psalmorly Committee of the L.I'. Church since $\mathrm{S} 6 \mathrm{~S}$ (with the exception of one year); clerk to the Committee luring the preparation of The Preshyterian Ifymal and Psalter: and was a member of the Music Committee of The Chureh Hymnary.

Langdon, Richard, born about I 729 ; appointed organist of Exeter Catherlral in room of John Silvester, leceased, Jume 23, I753; resigned Oetober +, 1777, when William Jackson sueceeded him ; appointerl organist of Ely Catherlral, November 26, 1777, but does not seem to have enterel upon the duties; appointed organist of liristul Cathedral in room of Samuel Nineard, 1)ecember 3,1777 ; elected one of the lay clerks of 
the Cathedral, November 30, 1778; resigned before June 25, I78I ; appointed organist of Armagh Cathedral, August 14, 1782 , in succession to Dr. Langrisehe 1)oyle ; resigned in 1794 , when he was sueeeded by Dr. John Clarke (afterwards ClarkeWhitfeld); graduated Mus. Hac. at Exeter College, Oxford, July 13, I761; died at Exeter, September 8, 1803, aged seventy-four.

Langran, James, son of Mr. Joseph Langran; born in London, November 10,1835 ; pupil of John Baptiste Calkin, Dr. Gordon Samders, and Sir J. F. Brilge ; organist of Holy Trinity Church, Tottenham, from 1859 to 1870 ; from 1870 to the present time organist of the parish chureh there; graduated Mus. Bac., Oxford University, r884; musical editor of the New Mitre-Hymnal, 1875.

La Trobe, Rev. Peter, son of the Rev. C. I. La Trobe; born in London, February 15, 1795; educated at Fulneek, Yorkshire, for the service of the Moravian Church; in $18_{3} 6$ succeeded his father as Secretary of the Unity of the Moravian Brethren in England; diel suddenly at Bertheldorf, near Hernhut, September 24, 1863.

Lawes, Henry, son of William Lawes; born at Dinton, Wiltshire; baptized January 1, $1590^{5}$; pupil of Giovanni Coperario; on January $1,162 \frac{5}{6}$, sworn in as epistler of the Chapel Royal, and on November 3 following, one of the gentlemen, and some time after clerk of the eheque; composed, in 1634, music for Milton's Masque of 'Comus,' produced at Ludlow Castle on Michielmas night in that year. He lost his appointments during the Protectorate, but was reinstated in them at the Restoration in 1660 . He died in London, October $2 \mathrm{I}, 1662$, and was buried in the cloisters at Westminster Abbey. It is Henry Lawes whom Milton addresses in the sonnet begimning ' Harry, whose tuneful and well-measured song,' ete.

Lee, William, succeeded William Popely in I 7 I 8 as organist, auditor, and reetor ehori of Southwell Minster; died 1754; buried in the north transept of Southwell Minster.

Legge, Alfred, born at Cambridge, June 1843 ; entering the choir of Trinity College, Cambridge, at the age of nine, he 
received his early musical training unter Profesor Walmisley and 1)r. J. L. Hopkins, to whom he was articled, afterwarls becoming asistant organist at Trinity Collegre; leaving Cambriklge, sturlied with 1)r. Stegrall at the Roval Academy of Music, aml later with l). l:. II. Turpin; organist of sit. Clement's C'lumeh, Cimbrilge, 186 i Wiekham, lierks, 186+; All saints, Cambrilues, $186_{5}$; since that year organist and choimaster of the l'arish Chureh, Ashford, Ient.

Linekar, Thomas Joseph, son uf Mr. John Linekar; born at Iloylake, C'heshire, (Jetober 6, 1858 ; from an early acy shower musical talent; sturlied music unler Wr. II. Jurle, of liverpool, for three years, hut principally self-tanght ; alpointel organist of lloylake Clumeh in $18-8$, holding the office for six years; afterwards organist of J.hmbill, Clinueh for three years; since $188_{7}$ organist of st. John's English Wesleyan C'hureh, Colwyn liay, North IV ales. Most of his eompositions

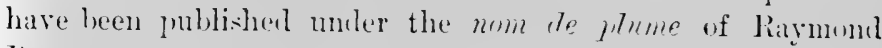
berenger.

Lloyd, Charles Harford, born at Thombury, (iloucestershire, Oetoluer 16, 18+9; educaterl at Rosiall sichool anrl Magrlalen

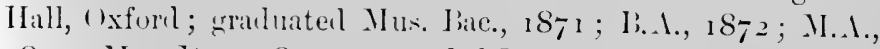

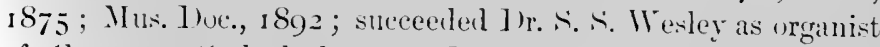
of (iloucester Cathedral, I876; 1)r. C. W. Corfe as organist of

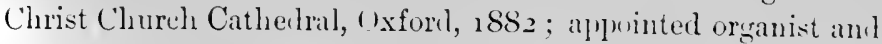
precentor of liton in sucession to Sir Joserh liarnhy, I 892.

Löhr, George Augustus, lwrn at Xorwieh, April 23, 1821 : ehorister at Masfilalen Collene, Oxford; assistant urganist for ten years to l)r. \%echarial liuek, organist of Norwich Cathelral ; appointed in November $18_{+5}$ orginist of sit. Margaret's C'hureh, Leicester, and afterwarls: choimatere : held these oflices till his ieath, August 25, 1897 .

Longhurst, William Henry, burn at Lambeth, Oetober 6, 1819; chorister in Cinterhury Cathedral unler Highmore Skeats, sen.; assistant organist to Thomas li. Jones, 1836 ; master of the choristers and lay clerk in the same year ; full organist, 1873 ; retired 1898 ; degree of Mus. 1)oe. conferred on him by Archbishop of Cinterbury, 1875 . 
Lowe, Albert, organist and composer; bookkeeper and manager to the firm of Ewer \& Co., musicsellers, London; on the purchasing of that business by Norello, Lowe beeame reader at their printing works in Dean Street; organist at Trinity Chapel, Concluit Street, London, under the Rev. J. I'. Waldo; afterwards organist with Mr. Waldo at St. Stephen's, London, S. IV., where he remained until his death, February 24, 1886.

Lowry, Rev. Robert, D.D., born in Philadelphia, Pennsylvania, United States of America, Mareh I 2, I826; edueated at Lewisburgh University, Pennsylvania, where he graduated in 1854 ; entered the Baptist ministry ; became, in 1869 , Professor of Rhetoric at Lewisburgh ; resigned his appointment in 1875 , and settled at Plainfield, New Jersey, where, in 1876 , he became pastor of the second Baptist Church; received the degree of Doctor of Divinity from his University in 1875 ; died November 25, 1899 .

Luther, Martin, the great leader of the Reformation in Germany, was the son of a miner. He was born at Eisleben, in Saxony, November Io, 1483 , and edncated at the University of Erfurt; professor of philosophy and divinity in the University of Wittenberg; died at Eisleben, February 18, 1546.

Macey, James Douglas, born at Maidstone, Kent, March ro, I 860 ; studied the organ at the London Organ School under the Rev. F. Scotson Clark. When nineteen years of age appointed organist of East Finchley Congregational Church, London, N., an office he held for about five years, and which he vacated to become organist and choirmaster to Lyndhurst Road Church, Ilampstead (of which the Rev. R. F. Horton, D.D., is minister), a post he still holds; appointed a member of the Consultative Iusical Committee to the Congregational Union in connection with the publication of their 'Mission' and 'Sunday School' Hymnals. For the last nine years Mr. Nacey has been associated with the well-known firm of organ builders, Messrs. J. IV. Walker \& Sons, London.

Macfarren, Sir George Alexander, born in London, March 2, 1813; pupil of Charles Lucas and others; appointed prin- 
cipal of the Royal Academy of Music, 1875; professor of music in the University of Cambridge, and Mus. 1)oc., I875; IIus. Doc., Oxford, 1879 ; received knighthood, 1883; lierl in London, October 3I, 1887 . During the greater part of his life he wats totally deprived of sight.

Maclagan, William Dalrymple, D.I), son of David Maclagan, II.1.; born in Edinburgh, June I8, 1826 ; early in life entered the army and served for a time in Inlia; retired with the rank of lieutenant; entered St. Peter's College, Cambridge, where he graduated I..1., 1856, and M.A. in 1860 ; took Ifoly Orders ; curate of St. Saviom's, P'allington, 1856 to 1858 ; St. Stephen's, Marylebone, 1858 to 1860 ; Seeretary to the London Diocesan Church Building Society, 1860 to 1865 ; curate of Entield, 1865 to 1869 ; rector of Newington, 1869 to 1875 ; vicar of Kensington, 1875 to 1878 ; consecrated Bishol of Lichfielı, I 878 ; honorary chaplain to the Queen, and prebendary of Reculverland in St. Paul's Cathedral, London; preferred to the arehbishopric of York, 1891.

Madan, Rev. Martin, son of Colonel Marlan of the Cinardi, and brother of Sprencer Miulan, Il.1'., prebendary of Peterborough ; born, 1726; founderl the Lock ILspital, London, of

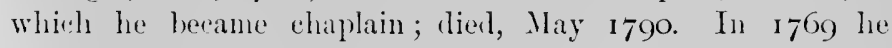
edited a Collection of I'salms and Hymms generally known as the 'Lock Collection.'

Main, Hubert Platt, born at Rilgrefield, Connecticut, Ingust 17, 1839; studied harmony in 1856 miler Dr. Thomas I Iastings ; composer of miny anthems and pieces for Sunday schools ; comnected with the firm of Liglow \& Main, musiesellers and publishers, Jew York, since its furmation in I 868.

Mainzer, Joseph, P'h. I)oc., was boru at Trives, Octuber 2 I, 1801. He received his elucation in the Maitrise of Trives Catherlral, and learned to play several musical instrunents. With a view to becoming an engineer, he spent some time in the coal mines near Saarbriick, but he at length entered the ecelesiastical profession and was ordained priest in 1826 , afterwards becoming an abbé. Ilis political tendencies forced him 
to leave Germany. In r84 I he competed against Sir Henry R. Bishop for the musieal professorship at Edinburgh University, but was unsuccessful. He met with much success as a teacher and organiser of singing elasses; his Singing for the Million was long popular, ant ran through many editions; died at Nanchester, November io, I85 I.

Maker, Frederick Charles, born at ]3ristol, I 844 ; ehorister in Bristol Cathedral, and pupil of the late Alfred Stone; organist of Milk Street Methodist Free Church; Clifton Downs Congregational Chureh; and from 1882 of Redland Park Congregational Church.

Mann, Arthur Henry, born at Norwich, May ı6, I85o; chorister in Norwich Cathedral under Dr. Zechariah Buck, and occasionally assistant organist; organist of St. Peter's Collegiate Chureh, Wolverhampton, I87o; of Tettenhall Parish Chureh, I87I ; of Beverley Minster, I875; of King's College, Cambridge, 1876 ; and to the University, 1897; music-master of the Leys School, Cambridge; graduated NIs. Jac., Oxford, I874, and Mus. Doc., I882. Dr. Manm acted as musical editor of The Chureh of England Hymnal, i 895 .

Martin, Sir George Clement, born at Lambonrne, Berks, September I I, I844; pupil of Sir John Stainer; organist of Lambourne Parish Church, ı860 ; graduated Mus. Bac., Oxforl, I 868 ; private organist to the Duke of buceleuch at Dalkeith, and organist of St. Peter's Episcopal Church, Lutton Place, Edinburgh, I87 I ; master of the choristers at St. Paul's Cathedral, I874; sub-organist, 1876 ; organist in succession to Sir John Stainer, I888; received the degree of Mus. Doc. from the Archbishop of Canterbury, r 883 ; knighterl by Queen Victoria, I 897 .

Martin, George William, born March 8, I828, and studied as a chorister in St. Paul's Cathedral under William Hawes. He also sang sometimes in St. James's Palace, when Her Majesty the Queen-then a young girl-used to attend the Chapel Royal with her mother, the Duchess of Kent. He was professor of music at the Normal College for Army School- 
masters, aud from June i 845 to Michaehmas 1853 was resident music-master at St. John's Training College, Balteriea. Ie was also the first organist of Christ Church, Battersea, which was opened in 8 8.9. He acted as rondu tor of the concerts of the National Choral society, the Metropolitan Schools Choral Society, and others; aml edited the Jommal of Part Music, I861-62. He clied at Bolingbroke House IHos]ital, Wandsworth, April 16, ı 88 I.

Mason, Lowell, son of Johnson Mason and Caty Hartshorn, was lorn at Mexlfiell, Massachusetts, January 8, 1792. When not much more than a boy, his fondness and aptitule for music placed him in the position of learler of a church choir in his native town. From Massachusetts he removed to Siavanah, where he was elerk in a bank. Here he conducted the pramoly of the large Preshyterian church, and compiled his first collection of Church musir. Oltaining leave of absence from the bank, he bent his steps to Philadelphiil, and offered the eopyright of his hook to the publishers, if he might hut receive a fow copies for his own use. They all declined the ofler; and when the young enthusiast went to luston, he fared no better. He was about to return to Sarannah, when he met a musieal gentleman who desires to examine the work. The gentleman expressed great satisfaction with it, and, with Lowell Mason's permisision, showed the manuscript to the Joard of Management of the lositun IIandel and Ifaydn Society, of which he was a member. That Society pulblished it, giving the author an interest in the work. It became immensely popular, and speedily ran through seventeen editions. This success decirted Lowell Mason's conrse of life. Ife twk up his abole at Ioston, hecame organist of Dr. Lyman beecher's church, and commenced the work of lecturing and publishing church music in earnest. In 1832 he established the Boston Academy of Music, and in 1838 obtainerl power to teach in all the schools of lioston. At the same time he fommled periorlical conventions of music teacher's, which have provel very useful, ant are now established in many parts of the States. He also publisherl a large number of manuals and 
collections, which sold enormously, and produced him a handsome fortune. His degree of Doctor in Music-the first of the kind conferred by an Amcrican college-was granted by the New York University in 1835 . He died at Orange, New Jersey, August I I, I872.

Mather, William, was born in $175^{6}$. He was organist of St. Paul's and St. James's, Sheffield, where he died in I 808 .

Matthews, Rev. Timothy Richard, born at Colmworth Rectory, near Bedford, November 4, I826; edlucated at Bedford Grammar School; graduated B.A. at Gonville and Caius College, Cambridge, I853; whilst private tutor in the family of the Rev. Lord Wriothesley Russell, canon of Windsor, in 1847 , he studied the organ under Sir George J. Elvey; rectur of North Coates, near Grimsby, Lincolnshire, since I 869; editel the North Coates Supplemental Tune Book and other collections of hymn tunes.

Meen, Fountain, born at Hackney, London, September i 4 , I846; for the most part a self-taught nusician; organist successively at Clapton Wesleyan Chapel ; St. Mary's, Stoke Newington; since I880 organist at Union Chapel, Islington; organist to the Sacred Harmonic Society during the last seven years of its existence; appointed professor of the organ at the Guildhall School of Music in succession to the late Josiah Pitman, I 886.

Mendelssohn - Bartholdy, Jakob Ludwig Felix, Ph.I.,-a degree conferred on him by the University of Leipzig in 1836 ,was born at Hamburg, February 3, i8og. He studied music from his earliest years; at the age of ten made his first public appearance as a pianist; and began systematically to compose in 1820 . The earlier part of lis life was principally spent in Berlin ; in 1835 he was appointed conductor of the Gewandhaus Concerts at Leipzig ; and in 1843 , mainly owing to his excrtions, the Leipzig Conservatorium was founded under his direction. He died at Leipzig, November 4, 1847, and was buried at Berlin.

Merrick, Rev. George Purnell, educated at King's College, London, and at Exeter College, Oxford ; graduated Mus. Bac., 


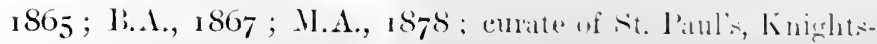

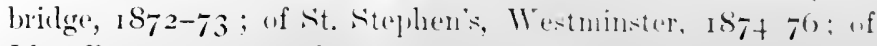
I.lanelly, $1876-77$ : ehaplain of ll..ll. I'ristls. Wistminster,

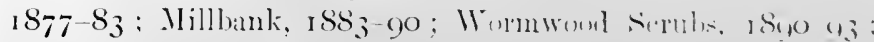

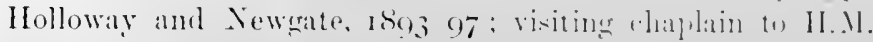
P'risons, linglinel and Wales, 1 \&ug.

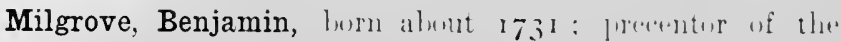

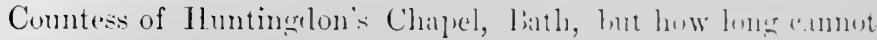
be ascertained ; lied 1810.

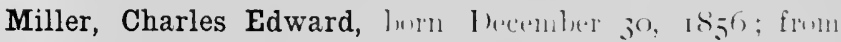

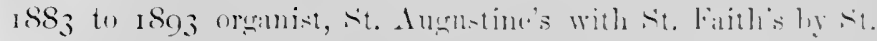

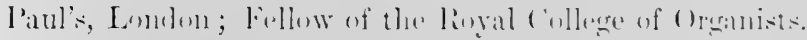

Miller, Edward, horn at Sorwich in $17.35:-211$ linl $1111 \mathrm{lu}$

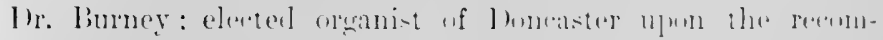

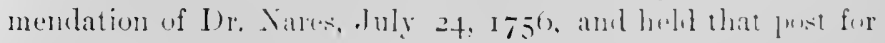

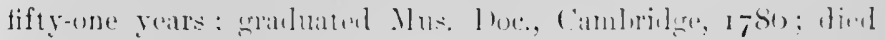
Sieptember 12 แr $1.3,1807$.

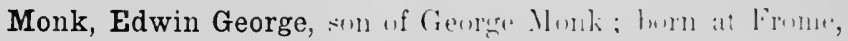

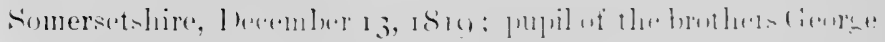

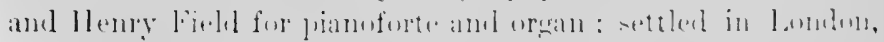

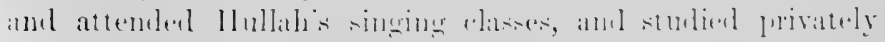

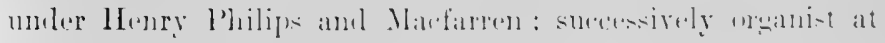

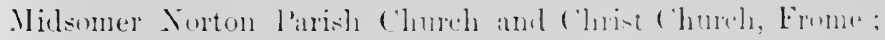

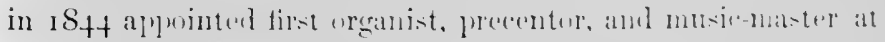

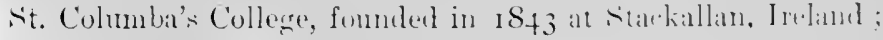
in $18+7$ settled at oxford as a tracleer of singing, amel the fol-

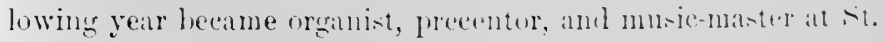

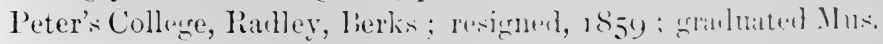

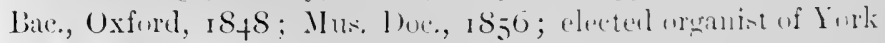
Minster, 1858 ; resigned, 1883 ; electerl a lellow of the lingal Astronomical finciety, $1871 ;$ from 1871 to 1883 um of the

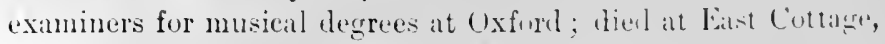
Rarlley, Ierkshire, January 3, 1yoo.

Monk, Mark James, bon at Ilumminhy, Jurkinire, Marel, I6, 1858 ; received his musical elncation at Jork Mluster, $1867-78$, under his uncle, I)r. l.. (G. Monk; wginilist at various 
churches in York; St. John's, Ladywood, IBirmingham, 1879; Parish Chureh, Ashby-de-la-Zouch, i 880; Banbury, 1883 ; and of Truro Cathedral from 1890 ; diocesan choirmaster and conduetor, choral festivals; precentor of leanery of Powler Choral Association ; conductor of Truro Philharmonie, I 890 ; grarluated Mus. Bac., Oxford, I878 ; Mus. Doc., ı888; Fellow of Royal College of Organists.

Monk, William Henry, son of William and Anna Coleman Monk; born in London, Mareh 16, 1823; pupil of Thomas Adams, J. A. Hamilton, and G. A. Griesbach; organist and choirmaster of Eaton Chapel, Pimlico, I841 to 1843 ; St. George's Chapel, Albemarle Street, 1843 to 1845 ; Portman Chapel, Marylebone, 1845 to 1847 ; choirmaster at King's College, London, 1847 ; organist there in 1849 , and professor of vocal musie in 1874 , on the resignation of Dr. Hullah; appointed organist of St. Matthias's Church, Stoke Newington, in 1852 ; legree of Mus. Doe. conferred on him by University of Durham, I882; died after a short illness, March I, I889; musical editor of Hymns Ancient and Modern and other important collections of Church music.

Morley, Henry L., for some time organist of St. Paul's Church, Herne IIill, London; resigned December $188_{3}$.

Morley, Thomas, son of Mr. Thomas Morley, of Longwall Street, Oxford, who carried on an extensive bookbiniling business; born at Oxford, January I, 1845; chorister at Queen's College, Oxford; studied music under the Rev. L. G. Hayne, Mus. Doc. ; organist of the Parish Church of Bradtielel, Essex, I861; of St. Albans, Holborn, London, I863, and of St. Ninian's Cathedral, Perth, I87o; private organist to the Earl of Kinnoul, I87 ; organist of St. James's, Tunbridge IVells, I876; Harmondsworth, 1880 ; St. Peter's, Vauxall, 188 I ; St. Barnabas, Oxford, I882 ; St. John's, New Brunswiek, ı886, where he diel November 1891 ; buried in the Churelı of England burying-ground, St. John's, New Brunswick.

Morley, William, graduated Mus. Bac., Oxford, in I713; gentleman of the Cliapel Royal, I7 5 ; died October 29, I72 I. 
Mornington, Garret Wellesley, first Earl of ; lwisn .Iuly 19. 1735; cratuated i.A., Mnhlin lniversity, 175t: 11.1., 1757:

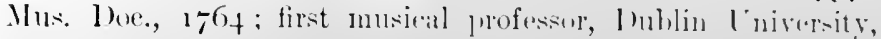

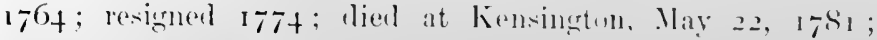
father of the Dulie of Mellingtom and of the Marpluis of Wellester.

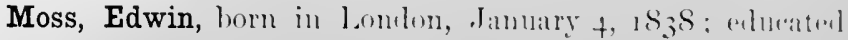
for the schulastic profession; commenced duties as heiblunater of a scheol at Camtitl, January 4 , 1858 , where he remaines] for four years; subsequently filled a similar pesition at Wantage, berkshire; relinquishert sehoul work for the musial prof ssion,

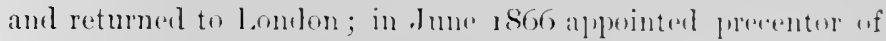

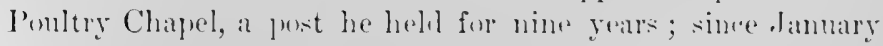
1877 , tenor voulist at the Finulling Cluapel.

Nares, James, som of $11 \mathrm{l}$. (iemere Xares: lum at Sitan-

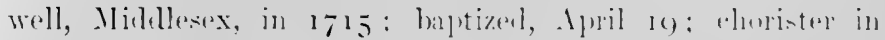

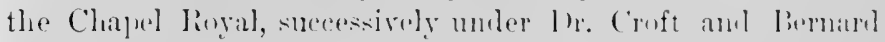
Gates, aml afterwarle a pupil of Jor. lepelseh; apleinterl

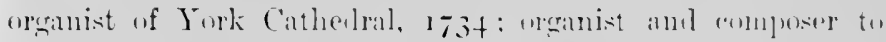
the Chapel lingal, 1756 : makter of the ehihleen in remen of

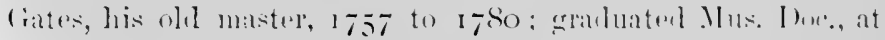

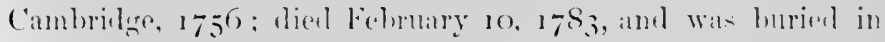
sit. Margiretis, Wistminster.

Neander, Joachim, burn at Bresuen in 16 go (wr, anereling tw

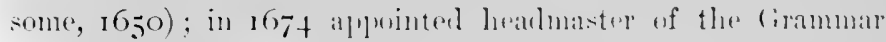

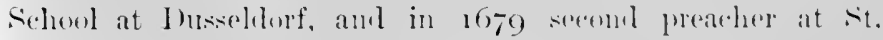
Martin's Chureh in liremen: died May $3 \mathrm{I}, 16 \mathrm{So}$

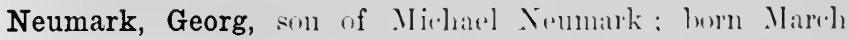
16, I62 I, at Langensalza, from whenee his fanily suberpuently

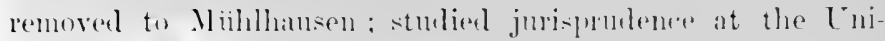

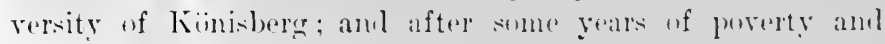
privation heeame, in 1651 , liharian of the arhives at Iteinar, where he died, July 8 , I6si.

Newport, Walter, son of an arehiteet: hurn at Manehester, Jecember 24, r839: elueated at Clapham (imanmar S.hool. near Iondon, where he was a rhorister ; urganist suecessively 
of Trinity Church, Lambeth, of St. George's Chapel, Albemarle Street, London, and of Hurstpierpoint Church, near Brighton; afterwards organist and choirmaster of Holywood Church, near Jielfast, about 1878 .

Nicolai, Philipp, son of Theodor (or Theodorich) Nicolai, Lutheran pastor at Mengeringhausen, in Waldeck; born at Mengeringhausen, August ro, I 556 ; studied theology at Erfurt and Wittenberg; occupied several pastoral charges; in $160 \mathrm{I}$ appointed pastor of St. Catherine's Church, Hamburg, where he died, October 26, I6o8.

Norris, Thomas, son of John Norris; born at Nere, Wiltshire; baptized in Nere Church, August I5, I741; chorister in Salisbury Cathedral; organist of Christ Church and of St. John's College, Oxford, $176_{5}$; lay elerk of Magdalen College, Oxford, I77 г Mus. Mac., Oxford, 1765; died at Himley Hall, Staffordshire, the seat of ILord Dudley and Ward, September 3, 1790.

Oakeley, Sir Herbert Stanley, son of Sir Herbert Oakeley, liart.; born at Ealing, Midldesex, July 22, I830; pupil of I)r. Stephen Elvey at Oxford, afterwards of Moscheles, Schneider, and others; I3.A., Oxford, I853; M. $4 ., 1856$; professor of music in Edinburgh University, in succession to John Donaldson, I 865 to 189 I ; Mus. Doc., Canterbury, I 87 I, Oxford, 1879 ; LL.D., Aberdeen, I88I, and composer of music to the Queen in Scotland; knighted 1876 ; elected a member of the Philharmonic Acadeny of Bologna, i 888.

Ouseley, Rev. Sir Frederick Arthur Gore, Bart., son of Sir William Gore Ouseley, the eminent Oriental scholar, who was successively ambassador and minister plenipotentiary to Persia and St. Petersburg; born in London, August I 2, I 825; named Frederick after the Duke of York, and Arthur after the 1)uke of Wellington, his godfathers; educated privately, and in I 843 entered Christ Church, Uxforl, as a gentleman commoner ; took Holy Orders, I 849 ; eurate of St. Barnabas, Pimlico, and St. Paul's, Knightsbrilge, 1849 to 1851 ; professor of music in the University of Oxford, and precentor of Hereford Cathedral, 


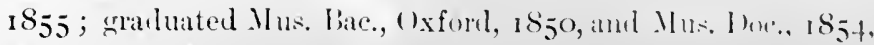

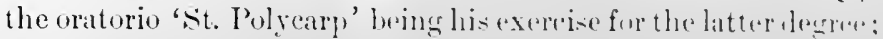
erected at Tonbury on a jurtion of his property a chureh an]

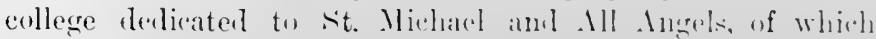
he was firet viear and warrlen: lienl sumlenly at llereforel, April 6, 1889: buried at si. Mielaels collewer, limbury. April 11.

Palestrina, Giovanni Pierluigi da, soll uf Sintø Pierluigi anıl Maria ( Hismonli, wals born at l'alestrina, in the frovinne uf Rome, rarly in the sixtenth eentury, the exart vear uf his birth heing as get undeterminet. IIo is believert to have sturlienl

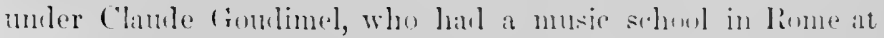

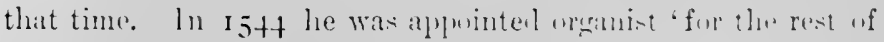
his life' by the eanons of St. Agageto, in his native town, but

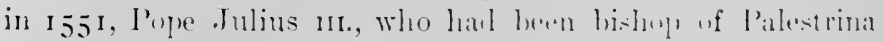
from $15+3$ to 555 , summomel him to linme and anferred an lim the oftice of "Mastro" of the Cappella fiulia in the Vatiean. Jalestrina spent the rematmler of his long life in

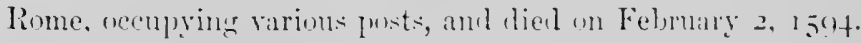

Palmer, Horatio Richmond, lurn at Sherburne, Xw Yurli

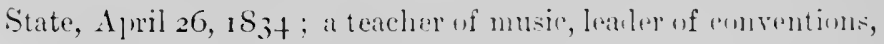
composer, ate.: from iso7 to a 880 he juhlisherl twonty-nine

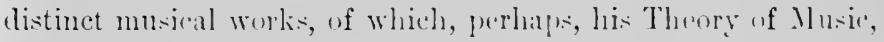
issued in $18 ; 6$, is the best known. The leerre of Mns. Ihw.

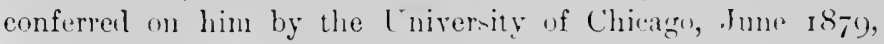

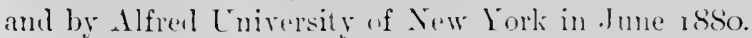

Parr, Rev. Henry, son of Mr. Thomils l'arr : lwrm at Lythwom!

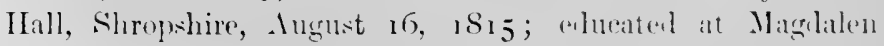
Collegre, lxford, and st. Hees, Cumberlam! : took Ifoly Order', $1 S_{45}$; viear of Timnton, Somersetshire, r $S_{49}$ to $1 S_{5} 8$; eurate of Tumbrilge, i 859 to i 861 : jerpetual curate of 1 sh Chureh,

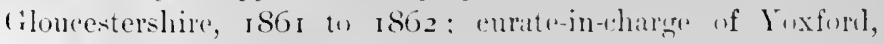
suffolk, 1867 : viear from 1872 to 1894. Mr. l'alr is the compiler of Clumeh of Finglaml l'salmonly (now in its righth elition), a work sjecially useful on account of the valuable and aceurate information it contains as to the composers and sourees of psalm and lyym tunes. 
Parry, Sir Charles Hubert Hastings, second son of Mr. Thomas Gambier Parry ; born at Bournemouth, February 27, I 848 ; educated at a private school at Malvern and at Twyforl School, near Winchester; entered Eton in I86I, and when eighteen years of age (r867) graluated Mus. Bac. at Oxford, his exercise being a setting of ' $O$ Lord, Thou hast cast me out'; in January 1867 went to Oxford and entered Exeter College; graduated B.A., I87o; pupil of H. H. Pierson at Stuttgart, also of Sir George Macfarren, Sir Sterndale Bennett, and Mr. Dannreuther; in 1883 appointed choragus of the University of Oxford; Mus. Doc. (honoris causî), Cambrilge, r $88_{3}$; Mus. Doc., Oxford, I884; appointed professor of composition and musical history in the Royal College of Music on its opening in $188_{3}$; succeeded Sir George Grove as director of the Royal College of MLusic, I884; knighted by the Queen, 1898; appointed professor of music in the University of Oxford in 1900.

Patten, William, born at Fareham, Hants, I 803 ; chorister in Winchester Cathedral, and pupil of Dr. Chard; organist of the Hospital of St. Cross, Winchester; died July 29, 1863.

Patton, Arthur St. George, eldest son of the Rev. George F. A. Patton, B.A.; born at Belfast, April 23, I853; erlucated at Trinity College, Dublin; organist of All Saints' Church, Blackrock, near Dublin, 1875 ; of Trinity Church, Rathmines, 1877; of St. Anne's, 1)ublin, 1881 ; died ı 892.

Peace, Albert Lister, son of Mr. Lister Peace; born at Huddersfield, January 26, 1844; a self-taught musician; appointed organist of Holmfirth Parish Chureh, Yorkshire, 1853 ; of Dewsbury Parish Church, 1858; St. Thomas's Church, Huddersfield, I 859 ; Brunswick Street Chapel, Huddersfield, I861; Providence Place Chapel, Cleckheaton, I863; Trinity Congregational Church, Glasgow, I 865 ; the University, I87o ; organist and choirmaster, St. John's Episcopal Church, I873; Maxwell Parish Church, 1875; Hillhead Parish Chureh, I 876 ; St. Andrew's Halls, 1877 , and in 1879 of the Glasgow Cathedral, a position he held till 1897 , when he removed to Liverpool on being elected-after competition-organist of St. George's Hall, in succession to the late IV. T. Best; graduated 


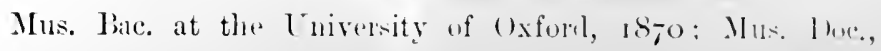

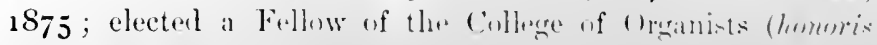
cansit), session 1886-87. Mr. Heace Wis 1musical enditur of the

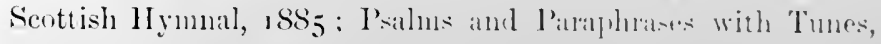

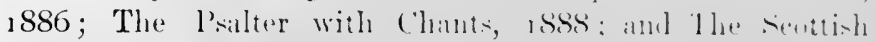
Anthem lmok, 1891.

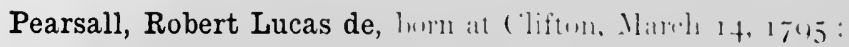

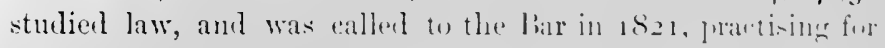

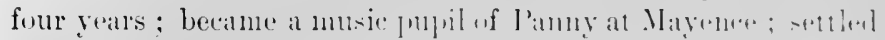

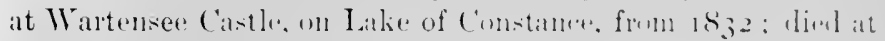

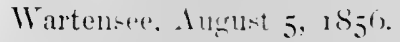

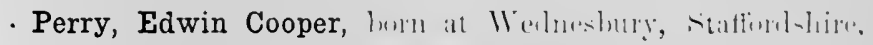

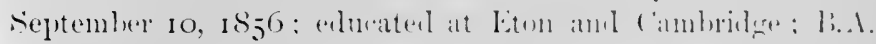

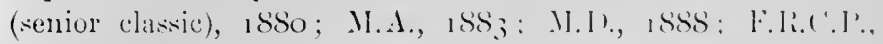
London, 189t: Fellow of King (

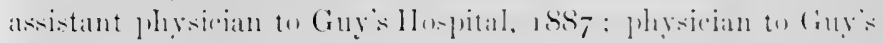

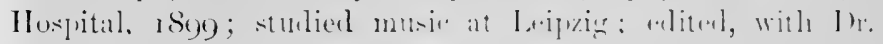

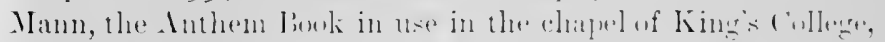
Cambrilge.

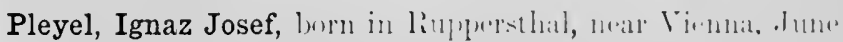

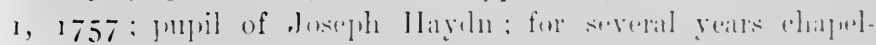

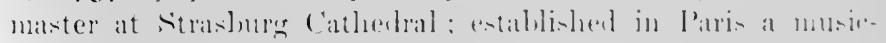

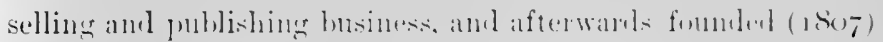

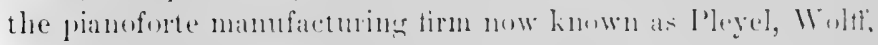

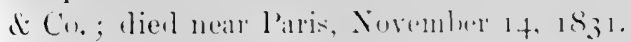

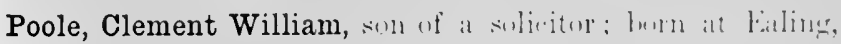

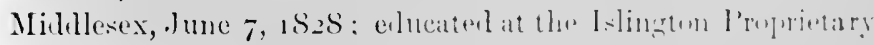

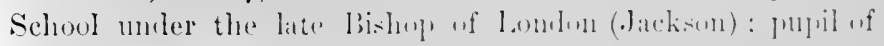

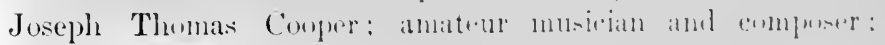

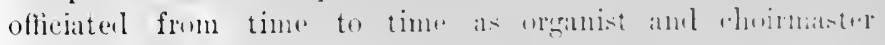

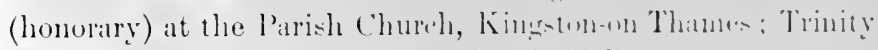

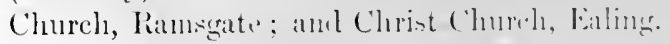

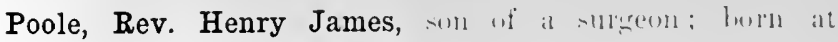

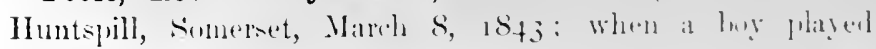
the flute in the band of the rhureh, where his mute was minister; studied music under the Line l.. (i. Hayme, Mus. 
Doc.; educated at Queen's College, Oxford; graduating B.A., I866; М.A., I870; ordained deacon, 1867; priest, 1869 ; curate of St. Matthew's, Manchester, i867 to 1869 ; Dulverton, Somerset, 1870 to 1871 ; Oakford, Devoln, I871 to 1873 ; Crambourne, Dorset, 1873 to 1874 ; St. David's, Exeter, 1874 to 1876 ; rector of Stowell, diocese of Bath and Wells, 1876; died January I5, I897.

Pring, Joseph, born at Kensington, 1776 ; chorister in St. Paul's Cathedral under Robert Hudson, MIus. Bac. ; succeeded Edmund Olive as organist of Bangor Cathedral, I793; Mus. Bac. and Mus. Doc., Oxford, 1808 ; died at Bangor, February I3, 1842 .

Prout, Ebenezer, born at Oundle, Northamptonshire, March I, 1835 ; B.A., London University, 1854 ; successively organist of St. Thomas's Square Chapel, Hackney ; the Congregational Church, Kentish Town ; the New Tabernacle, Old Kent Road ; St. Mary, Newington Butts, I859 to I861; Union Chapel, Islington, 1861 to 1873 ; professor of harmony and counterpoint at the National Training School for MLusic, 1876 ; professor of the Royal Academy of Music, 1879; professor of harmony and composition at the Guildhall School of Music, London, I884; professor of music in the University of Dublin, 1895 ; Mus. Doc., Dublin, honoris causî, 1895 ; Mus. Doc., Edinburgh, honoris causû, I895.

Purday, Charles Henry, son of a bookseller ; born at Folkestone, Kent, January I I, I799; at one time a vocalist of some repute; sang at the coronation of Queen Victoria ; engaged in music publishing for the greater part of his life; was an ardent adrocate for the revision of the law in matters of copyright in musical publications ; for some years director of the psalmody in the Scotch Church, Crown Court, London; composer of many lymm tunes; died $\Lambda_{\text {P ril }}$ 23, 1885 .

Randall, John, born 1715; chorister in the Clrapel Royal under Beruard Gates, from about 1730 to 1735 ; organist of Trinity and St. John's Colleges, Cambridge ; of King's College, about $17+5$; also of the University Cliurch, and of Pembroke 
Inall; Mus. Hae., Cambrilge, 174t; Mus. Huc., 1756: appointed professor of music in Cimbrilge University in succession to IMr. Naurice (ireene, r75.5; dienl Marh IS, I 799 .

Redhead, Richard, lorm at llarruw, in the entuty of Midillesex, March I, I8zo; colncated at Magrililen Collecre, Oxford; pupil of the Collerge orgunist, Walter Vieary, Mus.

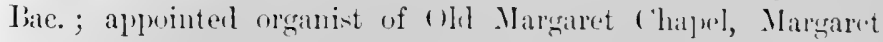
Street, Londun, in I839: afterwarls of 111 sinints' ('hurh, Margaret Sireet, till 1864 , and from that yeilr till 1894 , of sit. Mary Magdalen Churel, l'arldingtom.

Reinagle, Alexander Robert, lwru at lirighton, August 21 , 1799: son of Juseph Reinagle, at me time leirler of the harul at the Edinburgh Theatre, and well known in Scotlamel inning thr eighteenth century for his fine jerformandes on the vinloncello; appointed organint of St. I'eter's-in-the-Fint, Oxforl, 1822 (1) I823; resigned, 1853 : died at Kidlington, neir that city, . 1 pril 6, I877; buriel in Killington churchyarl.

Richardson, John, wis boln at l'reston, Herember It, 1816. He receiverl his eluration at the Fox street Catholic Sichool in that town. In early boyhool he showed at great taste for musie, and was a member of rit. Wilfred's Chureh Choir. In 1820 h" sang at the renpening of st. P'atrick's, liverpend, when his ability as an altu singer attracted attention. In the same your he wals engigged as principal alto singer at st. Picholas Catholic Chapel, Iiverpoul, at a salary of right or ten poumis a year: he was afterwards apprenticel as a honse printer and decorator, but dir not at the expiration of his apprenticehip follow that husiness. It nineteen gears of age he wis appointed organist at St. Mary's Catholic Church, liverpoul: two years later he returned to Sit. Nicholas Clanpel as organist-a post he held for over twenty rears. Ile tanght music at sit. lilwarl's College from a $8+4$ to 1857 , am hald an extensive fratice as a teacher; anong his pupils was the fanous organist, W. T. liest, who spoke in the highest terms of Richardion's abilities as an organist and teacher. In 1860 Richardson returned to I'reston 
broken down in health and constitution, and remained an invalid up to the time of his death, April 13, I879.

Rimbault, Edward Francis, son of Stephen Francis Rimbault, organist of St. Giles-in-the-Fields ; born in London, June 13, 1816; pupil of his father, also of Samuel Wesley and 1)r. Crotch ; organist of the Swiss Chapel, Soho, London, 1832 ; of St. Peter's, Vere Street, 1866 till 1871 ; afterwards of St. John's Wood Presbyterian Church, London; eminent musical antiquary; received the degree of LL.D. from the University of Göttingen in 1842; died in London, September 26, 1876.

Rink or Rinck, Johann Christian Heinrich, born at Elgersburg, Gotha, February 18, I770; pupil of Forkel and others; organist at Giessen, $\mathbf{1 7 8 9}$, and afterwards professor at the Music School there; organist and professor at Darmstadt University, I 806 ; court organist at Darmstadt, I813; Ph. Doc., Giessen University, 1840; died at Darmstadt, August 7, 1846.

Robinson, John, born I682; chorister in the Chapel Royal under Dr. John Blow; organist of St. Laurence, Jewry, London, I7ıo; of St. Magnus Church, London Bridge, I7ıo; assistant organist of Westminster Abbey; organist, I727, retaining his previous appointments; died $A$ pril 30, 1762, and buried in the same grave as Dr. William Croft, in the north aisle of Westminster Abbey.

Root, George Frederick, son of Mr. Frederick Ferdinand Root; born at Sheffield, Massachusetts, August 30, 1820; teacher of singing and organ at Boston, 1834 to 1843 ; music teacher in New York, where he established a school for the training of musie teachers, 1844 to 1855 ; removed to Chicago and founded the firm of Root \& Cady, 1860 to 1880, now Root \& Sons; degree of Mus. Doc. conferred on him by the University of Chicago in I872; died August 6, 1895.

Rousseau, Jean Jacques, son of Isaac Rousseau, a watchmaker at Geneva, where he was born June 28, 1712; author of a musical dictionary and of several pamphlets on music, but best known by his literary and philosophical works; died at Ermenonville, near Paris, July 3, 1778. 
Sangster, Walter Hay, lxm in London, september 17 , I835; chorister of the Temple ('hum huller li). E. I.

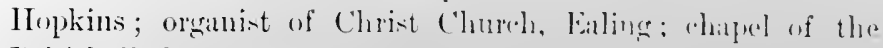

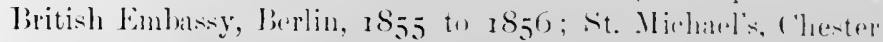

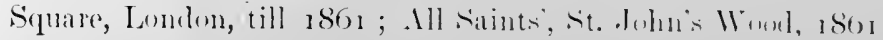

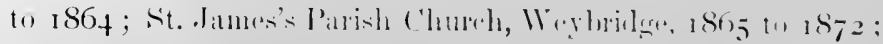

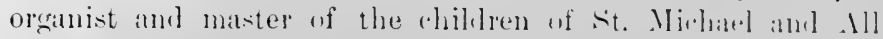

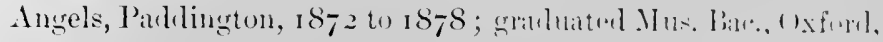

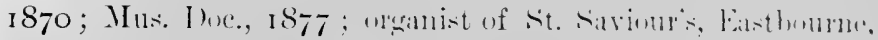
from 1880 till his deatl, Nitreh 2, 1899.

Schein, Johann Hermann, horn at firinhlityn, matr Zwickaw. Saxony, Janully 20, I586: from 1599 to 1603 was in the

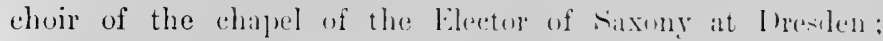

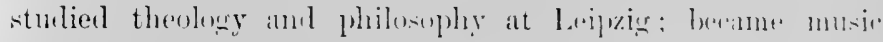

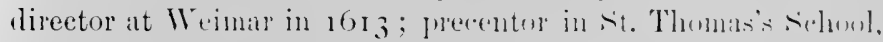

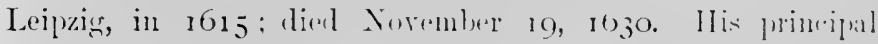

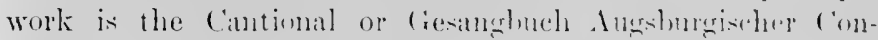

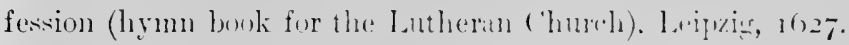

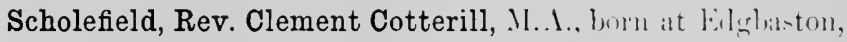

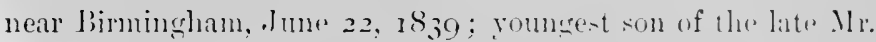
William sicholefichl, who was for twenty years II.I' for

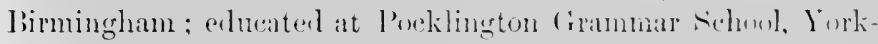

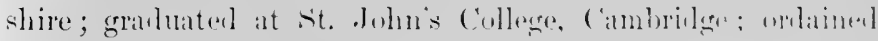
pastor of the prorish ehureh, Hove, brightom, in 1867 , wheme

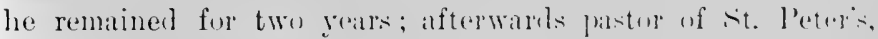

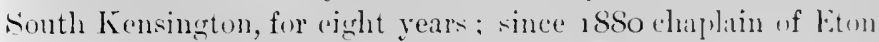
Colleser, Windsor.

Scholinus, Friedrich Karl Ludwig, lorn at Marelelurre, June 19, 1772; pastor at Nedlit\%, in Sixuny; dienl (1)tober 6, ${ }_{1} 816$.

Schulthes, Wilhelm, son of an officer in the fierman army: born at ILesse Cansel, feptemher 9, 1816 ; bromght 11 as at Lutheran, but beame a Catholic throngh reidling Frederick Faber's books; was received into the Church at the ()ritory, South Kensington, London, abont 1852, where shortly after he became director of the Oratory chusir, at position he held till 
I 872 ; teacher of music at the Convent of the Sacred Heart, Roehampton, from i 868 to i 879 ; died suddenly at Iiois-deColombes, near Paris, August 16, 1879; buried there.

Schulz, Johann Abraham Peter, born at Liineburg in I747; pupil of Kirnberger; from 1780 to 1787 conductor to Prince Henry of Prussia at Rheinsberg; from I 787 to 1794 court conductor at Copenhagen, whence he returned in 1794 to Germany; died at Schwedt, June io, i 800.

Shrubsole, William, youngest son of Mr. Thomas Shrubsole, farrier; born at Canterbury; baptized in the parish of All Saints, January I3, I 760 ; chorister at the Catherlral there from Lady-day 1770 to Michaelmas I777, and doubtless studied the organ under Samuel Porter, then organist at the Cathedral; appointed organist of Bangor Cathedral, I782, being allowed 'the sum of eight guineas towards the expenses of his journey, the removal of his Harpsichord and other effects from London to Bangor'; after repeated warnings, dismissed from office in $\mathrm{I}_{7} 8_{3}$ for frequenting conventicles or religious assemblies, where doctrines were taught contrary to those of the Church of England; settled in London as a music teacher, and among his music pupils were William Russell, organist of the Foundling Chapel, and Benjamin Jacob, of Surrey Chapel fame; appointed organist of Spa Fields Chapel, London, in I784, and held that office till his death on January i8, I8o6; buried in Bunhill Fields, London.

Silcher, Friedrich, born at Schnaith, a village in Würtenlburg, June 27, I789; pupil of Auberlen at Fellbach from 1803 to I806; appointed assistant teacher in the town of Sichorndorf in I806; removed to Stuttgart in I8I 1 , and in 1817 to Tiibingen, having been appointed to the newly instituted office of music director in the University there; in $185^{2}$ received the degree of $\mathrm{Ph}$. Doc. ; died August 28, i86o.

Simpson, Robert, a weaver by trade, was born at Glasgow luring the last decade of the eighteenth century. He led the psalmody for some time in Dr. Wardlaw's church there, but how long cannot now be ascertained. In $A$ ugust i 823 he was 
appointed precentor and sessionelerk of hlo Fals l'arish chureh, Greenock, at a salary of forty pommls a year, jmitions he was well qualified to fill, as he is sail to hitve herell at mitul of goul education, and an excellent musician aml vereslint. (1n his: removal to cireenock he male muse his profesion, and wats much and generally respecterl, being a puint and umobumaire man of simple and stmlinas habits. He wats of rather delicate

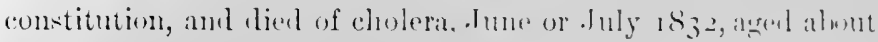
forty years.

Smart, Sir George Thomas, son of lieorse simart, mu-ic-

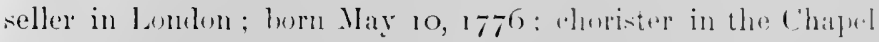

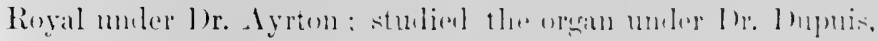

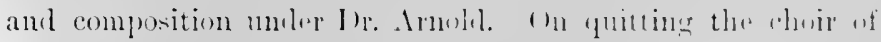
the Chapel Royal in 1791 , he whtimed the alpuntument of

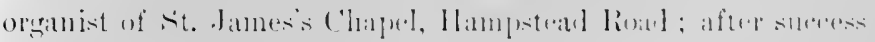

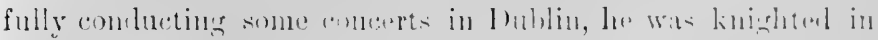

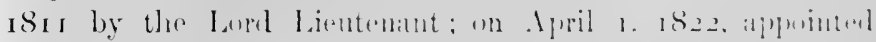

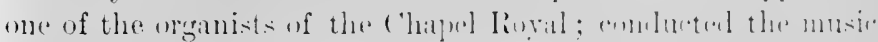

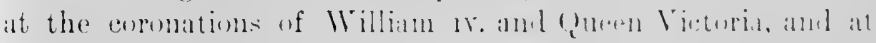
mamerous provineial festivils, at one of whels, liverpul in

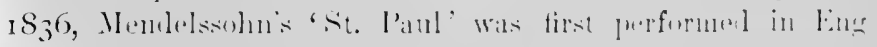

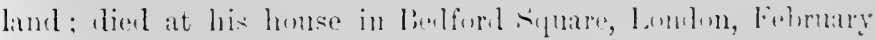
23,1807 .

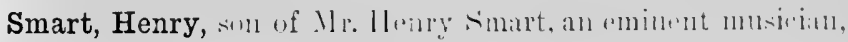

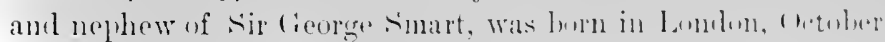
26, ISI3. Ifter receiving a commisimn in the Indian Immy,

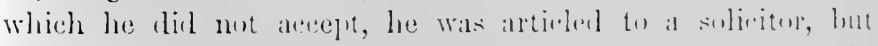

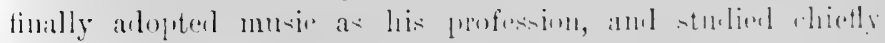

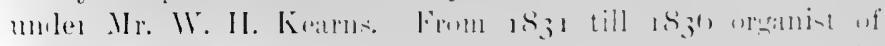

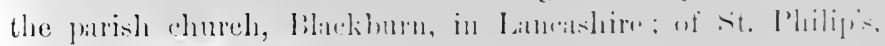

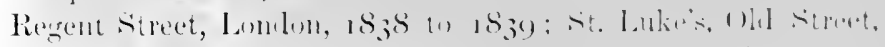

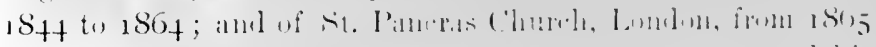
till he ried, July 6, 1879. For the lant fourteren geats of his life sinturt wats quile hliml.

Smith, Rev. Henry Percy, lum ISz-5; mlutatul at liallinl

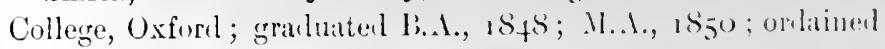
deacon, $18+9$; priest, $18_{50}$; enrate of Eversley, llants, $18+9$ to 
I 85 I; perpetual curate of St. Michael's, York Town, Farnborough, Surrey, I 85 I to 1868 ; vicar of Great Barnton, Suffolk, I 868 to I882 ; canon of Gibraltar, 1892 ; chaplain of Christ Church, Cannes, 1882 to 1893 ; died January i 898 .

Smith, Isaac, was elerk to the Alie Street Meeting, London; died about 1800 ; said to be the first Dissenting clerk that ever received for his services $£ 20$ per annum.

Smith, John Stafford, son of Mr. Martin Smith, organist of Gloncester Cathedral; born at Gloncester, I750; baptized March 30 ; pupil of his father and Dr. William Boyce; gentleman of the Chapel Royal, I784; lay vicar of Westminster Abbey, February 22, I 785; installed April I 8, I 786 ; vicar-choral of Westminster Abbey, 1794 ; organist of the Chapel Royal in succession to 1)r. Samuel Arnold, 1802 ; master of the choristers, I805 till 1817; died September 2 I, 1836 .

Smith, Robert Archibald, son of Archibald Smith and Ann Whitcher, was born at Reading, Berks, November i6, i 780 . His father was a silk-weaver in Paisley, but owing to a depression in trade, had left that town and settled in Reading in 1774 . Smith gave very early evidence of his genius for music, but his father insisted on placing him in his own workshop. The family returned to Paisley in I80o, and in 1803 Snith, who was suffering in health from his confined employment, and who showed no aptitude for his father's trade, was at last allowed to follow his inclinations, and to begin work as a teacher of music. In I8o7 he was appointed precentor and session-clerk of the Abbey Church, Paisley. For this appointment he was largely indebted to Dr. Boog, senior minister of the parish, who, himself a lover of music, had discovered Smith's merits, and become one of his warmest friends. In isio he published a small collection of psalmody, entitled Derotional Musie, Original and Selected, and he gave considerable assistance to Dr. Andrew Thomson, of St. George's, Elinburgh, in the compilation of sacred Harmony for the use of St. George's Church, i 82o. The result of his eomection with 1)r. Thomson was, that in 1823, when the precentorship of St. George's became vacant, he was asked by the kirk-session if he would be willing to accept 
the post. He replied in the aflimative, and on the unamimons refuest of the kirk-session, the Town Commil gitw him the

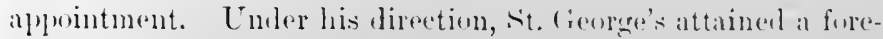
most place anomg the ehurches of Elinburgh in respert to its musie. He exlited sereral rollections of satered muse, which

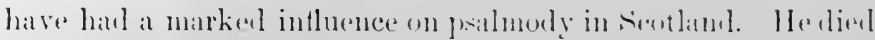
in Elinburgh on 3rd January 1829, and was huriml in sit. Cuthbertis churchyoul, the large attembance at his fumeral beange witness to the universil estern in which he was hell.

Smith, Samuel, sem of Edward Woulley sulth, lis plerk of

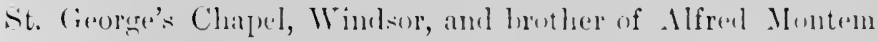

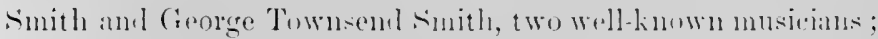
born at litul, August 29, 1821 ; in $8_{3} 1$ andmitted as one of the

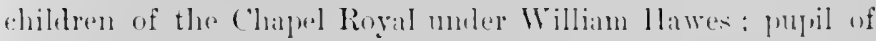

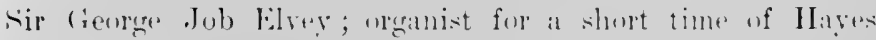

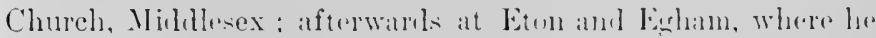

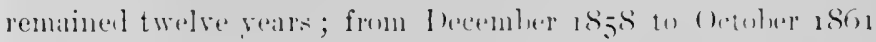

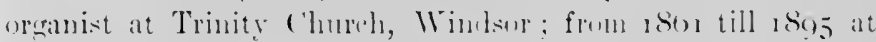
the l'arish chureh, Wimlsus.

Soaper, John, churister in st. l'alul's Cathelral muler William

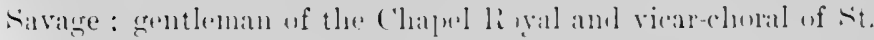

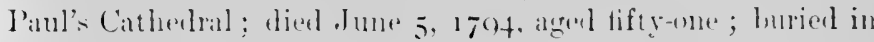
St. Panl's Citherlutl.

Somervell, Arthur, bum at Wimtermere. 1863 ; mlucated alt Cppingham Sichool amb Cambritge ; stulanl muse at berlin

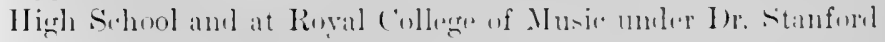
and vir Hubert larry.

Southgate, Rev. Frederic, soln of Mr. Fiandis sulltheritts,

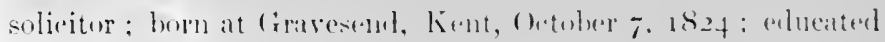

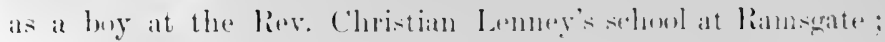

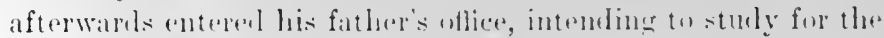

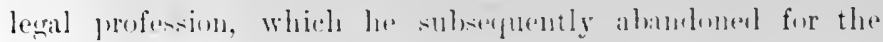

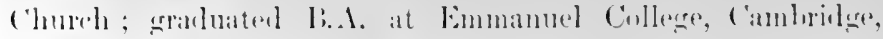

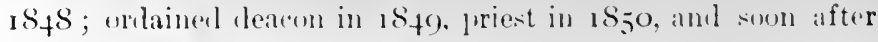
becime eurate at Cinstle llealingham, Sulfolk; a fow years later herame ineumbent of st. Marks, Rosherville, Kent; in 
1858 presented by the Crown with the living of Northfleet; died there January 30 , I885.

Spohr, Louis, son of Karl Heinrich Spohr, a physician; born at Brunswick, April 5, 1784; at an early age showert musical talent; studied harmony at Brunswick under Hartung, and the violin under Kunisch and Maucourt ; after travelling a great deal, he settled at Cassel in 1822, and was appointed director of the Court Theatre orchestra there, an office he held till 1857 , when he retired on a pension; died at Cassel, October 22, 1859 .

Stainer, John, son of a schoolmaster ; born in London, June 6 , I840; when seven years of age became a chorister at St. Paul's Cathedral, and remained there eight or nine years, during which period several chants and an anthem of his composition were performed at the services; pupil of George Cooper and Dr. Steggall ; organist of St. Benet and St. Peter's, Paul's Wharf, 1855 ; of St. Michael's College, Tenbury, $185^{6}$; Magdalen College, Oxford, 1859 ; gradnated as MLus. Bac. at Oxforl,

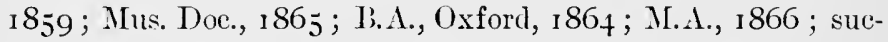
ceeded Sir Joln Goss as organist of St. Paul's Cathedral, 1872; resigned I 888, and received the honour of knighthood; appointed in 1880 principal of the National Training School for MLusic, and in $188_{3}$ inspector of music in Training Colleges; succeederl Sir F. A. Gore Onseley as professor of music in Oxford University, I889; resigned I899; died at Verona, Mareh 3 I, I90 I.

Statham, Rev. William, born at Tarporley Rectory, Cheshire, September 29, 1832 ; eldest son of the late Rev. Richard Jervis Statham, B.A., who was for thirty-five years rector of Tarporley ; educated at Marlborough; about ${ }^{2} 8_{5} 6$ graduated 13.4. at University Collegre, Durham ; ordained to the curacy of Tunstall, 1858 ; since 1866 vicar of Ellesmere Port ; degree of MLs. Doc. conferred on him by Durham University, 1876; died January 7,1898 .

Steggall, Charles, son of Mr. Robert W'illiam Stegrgall ; born in London, June 3, 1826; received his musical elucation at the Royal Academy of Music, principally under Sir William Sterndale Bennett; appointed a professor at that institution 
in $18_{5} \mathrm{I}$, and graduated Mus. Ware aml Mus. Hoe. at ('amblube in $185 \mathrm{I}$; organist of Christ Chapel, Maida IIill, $18+7$ : Christ Chmeh, Parlington, Lomdon, 1955: oreanist of Lincoln's lnn since 1864 ; sine 1882 examiner at Cimbridge for the deeree of Mıs. Doc.

Stewart, Sir Robert Prescott, Jorn in l)ublin, lncember 16, 1825: "horister in Christ ('hureh Catherlual, Hublin, 1833 to 18 fo: organist of Chrint ('humel Cathelral, a $S_{4+}$ : appointed in the same year organint of the chapel of Trinity

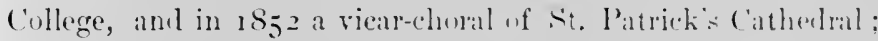
grarluated Mus. Dox. at Inblin Iniversity, I85l, aml was

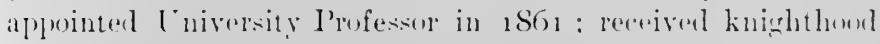
in 1872 from the Iond Limentenant of Ireland, larl siencer: dient in Inhlin, March 24, Isigy.

Sullivan, Sir Arthur Seymour, burn in Lmlun, May 1.3 . I $S_{f 2}$; sun of Mr. Thumas sullivan, a muritian, al native wi Cork; was a choriater in the ('hapel lingal, $185+$ to 1857 :

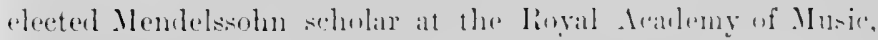

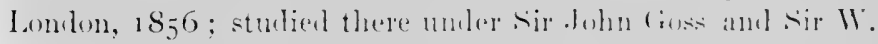

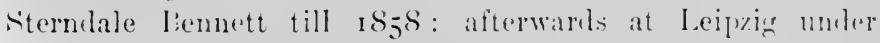
Plaily, Moscheles, Richter, Rictz, aml Mauptmann, frum 165 to 1861 ; wranist of sit. Michacl's, Chester sifuare, till 1807 ,

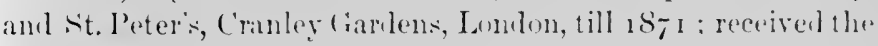
lecree of Hoctor in IInie from the lniversity of Cimbrilger, 1876 , and from oxfoml lniversity is 89 : knighted 1liy 15. I 883 ; died in Lomlun, Norember 22, 1900.

Sweeting, Edward Thomas, sul of Mr. LAwild sweting:

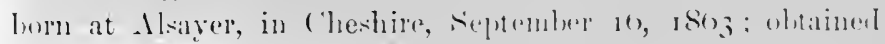

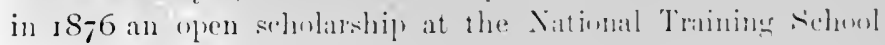

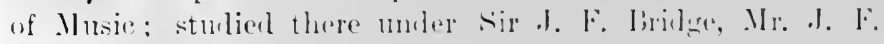

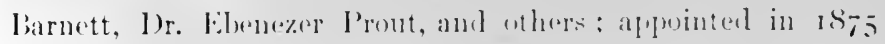
organist of st. Mary" West Konsington: in 1882 mgthint an1]

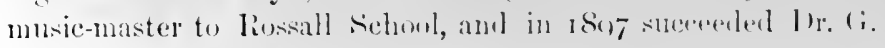

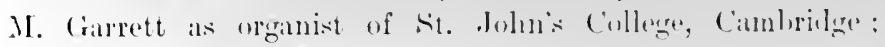
Fellow of the Royal College of Mrganits, 1879 ; graluated as Mus. Bac., Oxforel, 1 888 ; Mus. Ive., 1893. 
Swift, James Frederick, son of Joseph Swift; born at Manchester, December 28, I847; removel to Liverpool in I $85 \mathrm{I}$, and was educated at the Commercial School of Liverpool College; at an early age he displayed a remarkable talent for music, and performed in public as a pianist when twelve years old; in 1863 became organist of the Cranmer Wesleyan Chapel; afterwards for ten years organist of St. Andrew's Church, and in 1886 appointed organist of St. Bride's Church, all in Liverpool.

Sykes, Sir Frederic Henry, Bart., son of Sir Francis William Sykes, Bart., and Henrietta, daughter of Henry Villebois, Esq., of Marham ; born 1826; succeeded his brother, ı 866 ; died, г 899.

Tallis, Thomas, born about 1520 ; a gentleman of the Chapel Royal in the reigns of Henry vin., Edward vi., Mary, and Elizabeth; organist of Waltham Abbey till its dissolution in 1540 . He died November $\mathbf{2 3}, 1585$, and was buried in the chancel of the parish church of Greenwich.

Teschner, Melchior, was precentor at Fraustadt, in Posen, about 16 13 , and subsequently pastor of Oberprietschen, near Fraustadt. His biography is obscure.

Thomson, Rev. Andrew Mitchell, son of the Rev. John Thomson; born at Sanquhar, Dumfriesshire, 1778 , and baptized July I I ; licensed by the Presbytery of Kelso, I802, and in the same year ordained minister of the parish of Sprouston, Roxburghshire; in 1808 elected minister of the East Church, Perth, and in 1810 of New Greyfriars', Edinburgh; on the erection of St. George's Church, Charlotte Square, Elinburgh, he was appointed by the Tuwn Council minister of that church, and inclucted June 16, 1814; degree of M.A. conferred on him by Elimburgh University, March 14, I8ı I ; D.D., by Marischal College and University, Aberdeen, Novenber 1, 1823; died suddenly, while returning from a meeting of Presbytery, Feloruary 9, 1831 ; buried February i 5 , close to St. Cuthbert's churchyarl, in a piece of ground which now belongs to the trustees of St. John's Episcopal Church. 
Thorne, Edward Henry, hwol at Cranbeurne, l horet, May g,

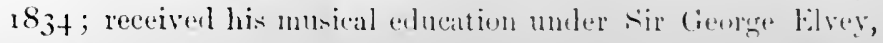
at st. George's chapel, Wimlsor, where at the early ane of twelve years, he was, on areunt of his exceptional talent,

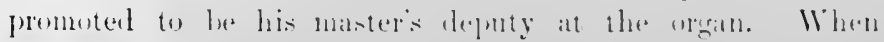
eighteen geats of atge he was alpminted momist and cheirmaster at the l'arish ('hureh, Henley-on-Thanes, and in 1 ses he filled similar oflices in chichester cathentral. leaving Chichester, he helil the following aldwintments: - st. l'atrick:

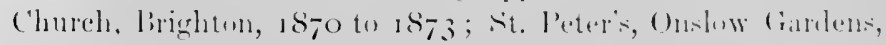

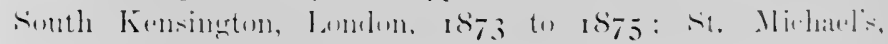

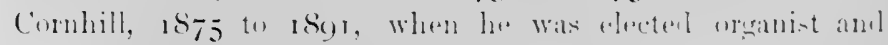

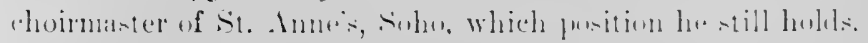

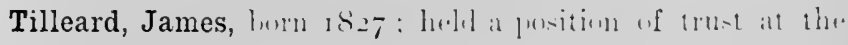

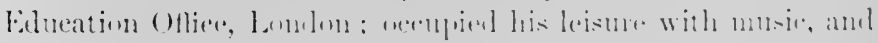

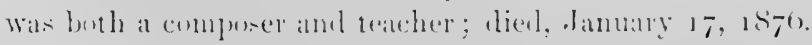

Tours, Berthold, bern leecember 17,1835 , at linttertan; pupil of his father, who was artanist of the st. lawwenese

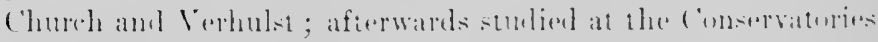

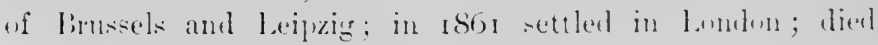
Ifirch 11,1897 .

Troyte, Arthur Henry Dyke, Im,rn llay 3, 1811 : secoml

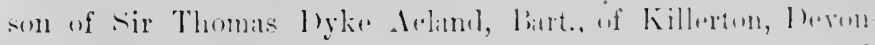

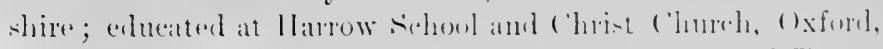

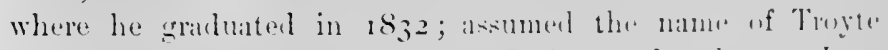

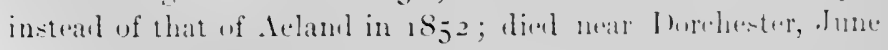
19,1857

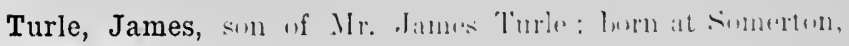

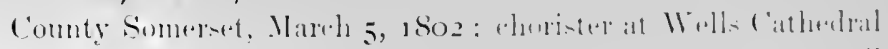

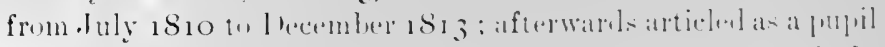

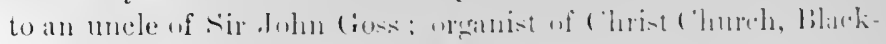

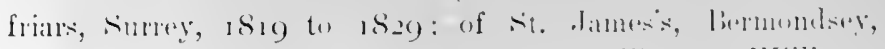

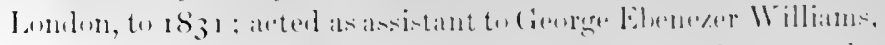
organist of Westminter lbley, and afterwatels beame the permanent deputy of Thomis Greaturex, ITilliams's smeesent. On the death of cireatorex, July is 31 , Turle, whe was then 
only twenty-nine, was appointed organist and master of the choristers by Dean Ireland. Turle acted as organist at some of the great English musical festivals, notably the one held at Norwich in 1839 , when Spolyr's oratorio 'Calvary' was produced under the direction of the composer. He was also one of the organists at the Handel Festival held in Westminster Abbey in 1834 . Turle retired from active duty on September 26, I 875 ; he retained a titular connection with the Abbey, and lived in his cloister-house till his death, which took place on June 28, i 882 .

Turle, Robert, brother of the preceding, borm either at Somerton or at Taunton, March 19, 1804; organist of Armagh Cathedral from 1823 to 1872 ; died at Salisbury, March 26, 1877 .

Turpin, Edmund Hart, born at Nottingham, May 4, I835; pupil of Charles Noble of Nottingham and others; organist of St. Barnabas Catholic Chureh, Nottingham, from 1850 to 1864 , performing by deputy from 1857 , when he removed to London; organist of St. George's, Bloomsbury, from 1869 to I888; now organist of St. Bride's, Fleet Street; honorary secretary of the College of Organists since 1875 ; degree of Mus. Doc. conferred on him by the Archbishop of Canterbury, r889.

Turton, Rev. Dr. Thomas, born February 25, I780; educated at Cambridge, and in 1805 proceeded B.A., being Senior Wrangler; in 1806 elected a Fellow of his College, ant in the following year succeeled to the office of tutor; graduated M.A. in 1808 , and served the office of moderator for the years 1810, I8I1, 1812; Lucasian professor of mathematics, 1822 to 1827 ; rector of Gimingham and Trunch, Norfolk, 1826 to 1827 ; regius professor of divinity at Cambriclge, and prebentary of Lincoln Cathedral, 1827 ; canon and dean of Peterborough, $18_{3} 0$ to $18_{42}$; dean of Westminster, $18_{42}$ to I845; bishop of Ely, 1845 ; died at Ely House, Dover Street, Lonion, January 7, 1864 .

Tye, Christopher, graduated as Mus. Bac. at Cambridge in I 5.37 ; Mus. Doc., ${ }^{1} 545$, and in ${ }^{1} 548$ was admitted ad eundem 
at Oxford. Lecent investigations hy Mr. II. Barelay sipuire show that Tye was in orders, and held snceesively the reeterim of Little Wilbratiam, Sewton, and Juhlington-emm-Yareh.

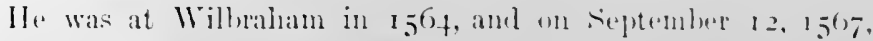
Jalan Walker was presented to the living un his resignation.

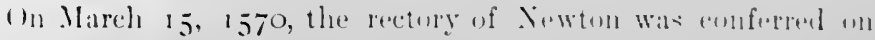

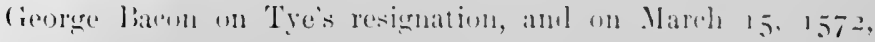

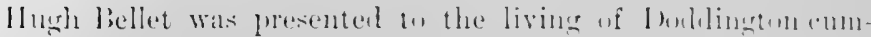

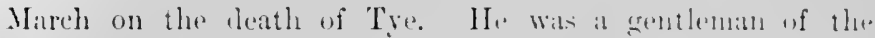

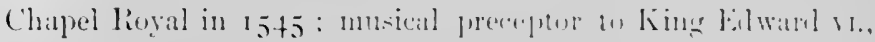
and organist of lily Cathedial, i $5+$ t to 1562.

Tyler, James Sherman, born in simth Lomlen, (1.tulnel 20,

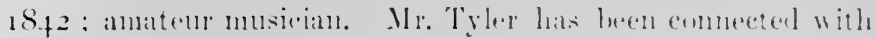

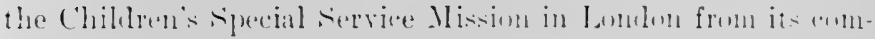
meneement, and in anjunction with his lmother, Ml. Sitnullel

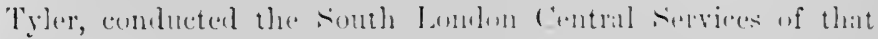

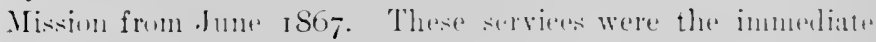

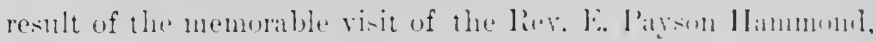

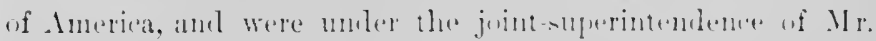

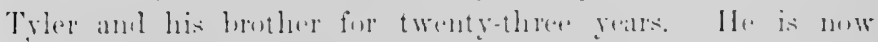

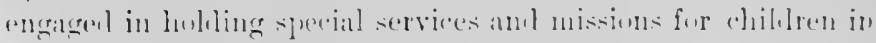

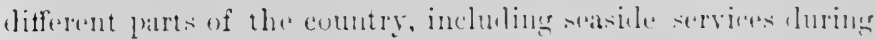
the summer.

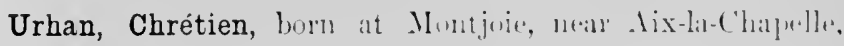
February 16, 1790: in early life showel great antitule for music, and receivent his primary tuition on the violin from his father, who likewise instructed him in compusition: the

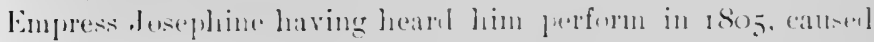
him to be instrueted in compusing hy let suene at l'aris. He

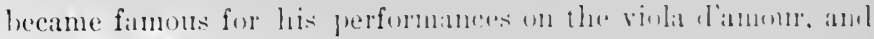
Meverheer wrote sperebilly for him the solo for that instrument in the 'Huguenuts. He was sule vinlinise in the orehe-trat

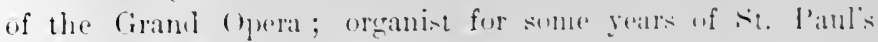
Church: died at lielleville, neall l'aris, Nowemler $2,18+5$.

Vincent, Charles John, horn at IIoughton-le siring. l hurhanu, September 19, 1852. Ilis father, Charles fuln Vinent, was organist of St. Michates Clunrels in that place. In $186 . t$ 
Vincent entered Durham Cathedral as a chorister, studying under Dr. Armes after receiving his first lessons from his parents. In 1869 he was appointed organist of Monkwearmouth Parish Church; studied at Leipzig Conservatorium, г 876-78; graduated Mus. 13ac., 1878, Mus. Doc., r 885, Oxforl ; organist of Tavistock Parish Church ant Kelly College, i878; and of Christ Church, Hampstead, Lonton, r 883-91 ; honorary secretary of the London section of the Incorporated Society of Musicians, and divisional (Oxford) honorary secretary, Union of Graduates in Music; examiner for Trinity College, in which capacity he visited Sonth $\Lambda$ frica, r 893, and Australia, I897.

Vulpius, Melchior, born at Wasungen, in Thuringia, I560; about I6oo became precentor at Weimar; died there i6ı, or, according to some, 1621.

Wainwright, Richard, son of John Wainwright; born I758; some time organist of the Collegiate Church and St. Ann's, Manchester ; succeeded his brother Robert at St. Peter's, Liverpool, September I782; afterwards organist of St. James's, Toxteth Park; reappointed to St. Peter's, r8r3; died August 20,1825 .

Wainwright, Robert, son of John Wainwright; born I748; succeeded his father at the Collegiate Church, Manchester; accumulated the degrees of Bachelor and Doctor in Music at Oxford University, April 29, r774, on which occasion a grind Te Deum of his composition was performed; appointed organist of St. Peter's, Liverpool (now the Cathedral), March I, I775; died July I5, I782.

Walmisley, Thomas Forbes, son of William Walmisley, clerk of the papers to the House of Lords; born at Westminster, May 22, I783; chorister in Westminster Abbey; studied under Thomas Attwood; assistant to William Horsley at the Female Orphan Asylum, i8 Io; succeeded Robert Cooke as organist of St. Martin-in-the-Fields, I8I4; resigned $18 \mathbf{5}_{2}^{2}$; died at Earl's Court, July 23, I 866.

Walton, Herbert Francis Raine, born at Thirsk, Yorkshire, February 27, I869; studied under his father, who was a 
schoolmaster, and organist of the Parish C'hureh of Thirst; when twelve years of age appointed organist at Kirlily-Winke Chureh, studying at the same time umler l)r. John Naylur of York Minster ; in 1886 gilined a three vears' open shlolitrship

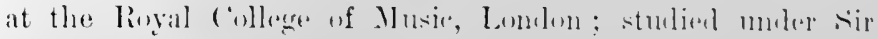
Walter l'arratt, Nir lluhert l'ary, Mr. Ferlerick Clille, and

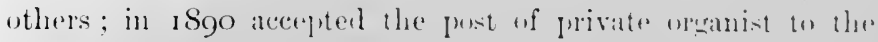

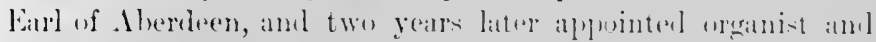

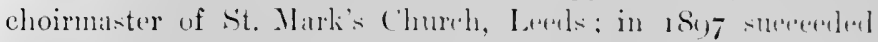

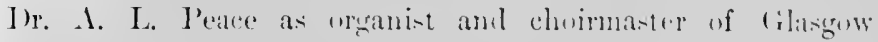
Citheelral.

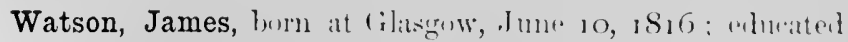

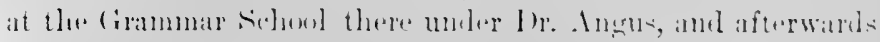

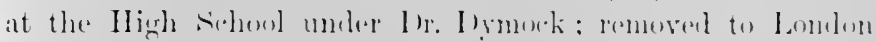

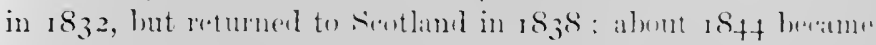

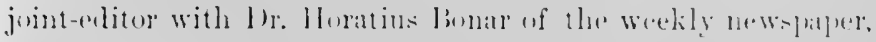

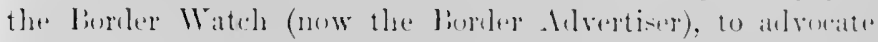
the spreal of free Cloureh views; in $18+5$ leenane a partuele in the well-knuwn firm of fame Xislut of Co. pulli-luers, Lonelon, and at Mr. Nishet's death, chief partuele member of

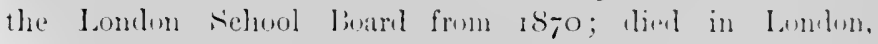
September 1, 1880 , and humbl in lliglagate cinnetery.

Webb, George James, was hrm at liushmore lomler, mill

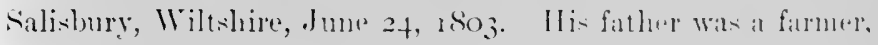

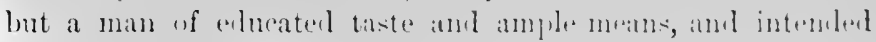
his son for the ministry; the lattrer, howerer, mantesting at

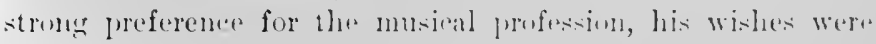

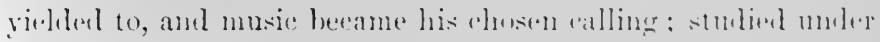

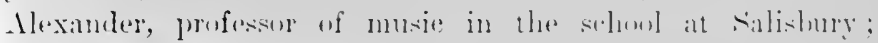
appointed to a chureh at Filnumth, an ofliwe he resigned in

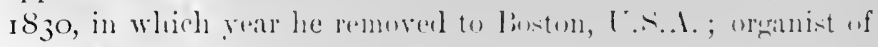

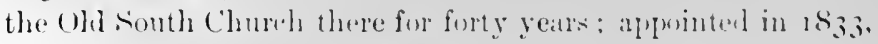
with I)r. Iowell Mason, professon! of muse in the lontont Academy of Music ; establishled in 1835 (alls) with l)r. Masmu) conventions for the instrution of music temehers: elected president of the loston IIamlul and Ilaylu siociety in s $S_{f}$ : conductor for a time of the Memelelsiohne ('horal siedely : in 
I870 removed from Boston to Orange, New Jersey, and in i 876 to New York, but returned to Orange, New Jersey, in is8, and clied there, October 7, 1887.

Webbe, Samuel, born in I740; his father having been a goverumental official in Minorca. He was at first apprenticer to a cabinetmaker, but his musical proclivities attracted the attention of Charles Brabandt, who gave him some lessons. It is probable that he occasionally acted as IBrabandt's deputy at the Portuguese and Bavarian embassies. In 1794 he was appointed secretary to the Noblemen and Gentlemen's Catch Club. About 1793 he was organist at the chapel of the Sardinian embassy. He died in London, May 25, I816, ancl was buried in old St. Pancras Churchyard.

Wesley, Charles, son of the Rev. Charles Wesley, ancl nephew of the Rev. John Wesley, the Methodist leader; born at Bristol, Decenıer II, I757; becane a pupil of Kelway; organist of several churches in London; died May 23, I834.

Wesley, Samuel, son of the Rev. Charles Wesley; born at Bristol, February 24, I766; from I782 pupil for a short time of David Williams, organist of St. James's, Bristol ; officiaterl as deputy organist for one Tyler at the Abbey Chureh, Bath; came to London, and was candidate for the organistship of the

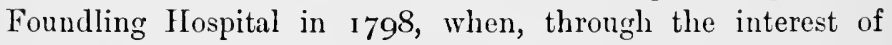
Joah Bates, John Immyns, an amateur, was elected ; organist of Camclen Chapel (now St. Stephen's Parish Church, Pratt Street, Camden Town), I824; died October I I, I837; buried in Marylebone old churchyard.

Wesley, Samuel Sebastian, son of the preceding; born in London, August I4, I810; chorister at the Chapel Royal, St. James's ; in 1826 appointed organist at St. James's Church, Hampstead Road, London, and three years afterwarls of St. Giles', Camberwell; subsequently organist of St. John's, Waterloo Road, and of Hampton-on-Thames; appointed organist of Hereford Cathedral, 1832 ; Exeter Cathedral, 1835 ; Leeds Parish Chureh, I842 ; Winchester Cathedral, 1849; and Gloucester Cathedral in $186_{5}$. This post he held till his death, April 19, 1876. 
West, Hezekiah, ehorister in New College, (Ixford, and afterwards lay clerk there, 1822-1824; iliel is 826 .

West, Rev. Lewis Renatus, a minister of the I'nited Brethren's Church; son of Mr. John West; born in Lonton, May 3 . I753; entered the Ifravian loys' loarding sidool at Fulneck, Yorkshire, in 1776 , as one of the 'master's'; settleel in liedfort, June 5 , 1782 , als tutor in a family, and assistant preacher, resigning Deember 29, $17 S_{3}$; settlet in luhlin, Jannury 28 , 1784 , as assistant minister, with special eare of the yomg men, of the Moravian congregation: ordained datan of the bretheren: Chureh hy lishop, Traneker, $A_{\text {pril }}$ or Yay 1785 : from ahout 1790 to 1795 minister of (iracehill, lreland : afterwarls resident at Yirfielel, lorkilire; alwo at lath and bri-tol: became minister of the lirethren's Chureh at Tythertm. Wiltwire, in

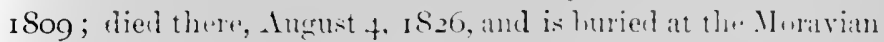
Burial (irounls.

Wheall, William (or Weale), graduatenl Mlus. liate at cambridge in 17 19. Ile was organist of st. Paul's ( humch, liedfort.

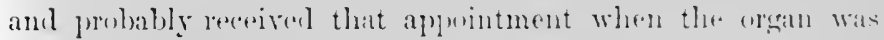

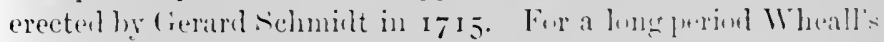

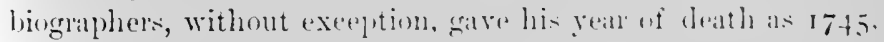

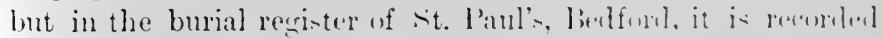
that he was interred septemlner f. 1727 .

Wilkes, John Bernard, stmlied at the lingal leinlemy of Musie, London, from $18+2$ to 1876 ; alwnt 1860 orgunist at Monkland Chureh, near L,eminster, Herefurl-hire, when the Rev. Sir Ilenry W. lakere was rialr: afterwarls orginist of St. David's, Merthyr Tydvil, and then of Llandant Cathedral, 1861 to 1865 ; after which he settled in Lontlun.

Willing, Christopher Edwin, son of Mr. Chri-tulhe." Willing. alto singer and asistant gentleman of the (hialy-l lingal : hern in Devon, Fehunary 28, 1830 ; chorister at IFe-tuninster theey under James Turle, whose pupil and deputy he afterwarls beeame; appointed organist at lBlackheath l'ark (hurch whon fifteen years of age; organist at the Foundling (haled, Londun, Narch $11,18.48$; resigned Novemher 12, i 879 ; for a few years 
organist at All Saints', Margaret Street, and St. Paul's, Covent Garden; for many years organist and sub-conductor, under Sir Michael Costa, of the Sacred Harmonic Society ; first conductor of the Festival of St. Alban's Choral Union, conducting it for upwards of twenty years.

Wilson, Hugh, was born at Fenwick, Ayrshire, in 1766, and baptized December 2 . He received his education at the village school, and afterwards learned the shoemaking trade with his father, John Wilson. In his spare moments he applied himself assiduously to the study of mathematics and kindred subjects. A favourite pastime of his was the making of sundials, and one constructed by him was lately to be scen at Fenwick. He occasionally led the psalmody in the Secession Church there, and was able to add to his income by teaching the villagers the ordinary branches of education and music. About the end of the eighteenth century Wilson removed to Pollokshaws, where he made the acquaintance of Mr. William Dum, in whose mills there and afterwards at Duntocher he held important positions; being a skilled draughtsman and calculator, his services were highly valued by Mr. Dunn. Wilson filled the office of a manager in the Secession Church at Duntocher, and founded, with one James Slimmond, the first Sabbath school at Duntocher. He died on August I4, I 824, and was buried in the churchyard of Old Kilpatrick.

Woodbury, Isaac Baker, born at Beverley, Massachusetts, October 23, 1819; apprenticed to a blacksmith in Boston, and spent his spare time in educating himself and learning the violin; in 1839 he became a member of the Bay Street Glee Club; visited England in $184 \mathrm{I}, \mathrm{I} 85 \mathrm{I}$, and 1856 or 1857 ; settled in New York, 1849 ; in 1858 started on a trip to the South for his health, and only reached Columbia, South Carolina, where he died, October 26, I 858 .

Woods, Francis Cunningham, son of Mr. Alfred Woods of Ingate Lodge, Ieccles; born in London, August 29, I862; student at National Training School for Music, under Sullivan, Stainer, IBridge, Prout, and others; organist of Brasenose 
College, "Ixfort, I883-1886; urganist of lixeter Cinllegu, Oxford, I886-1895: private organist to the luke of Marlborough, 1891-1S94; conductor of (x) xurl Chural and Ihilhamonic society, 1893-1895; comluntor if linshury Choral

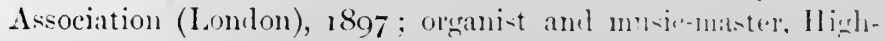

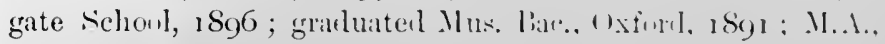

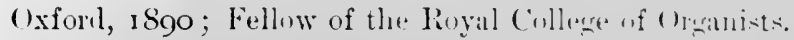

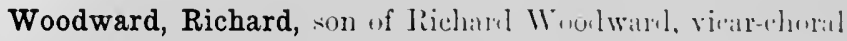
of sit. Jatrick's and Christ Chureh Catherlrals, Mublin: born in

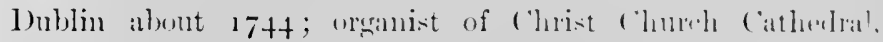

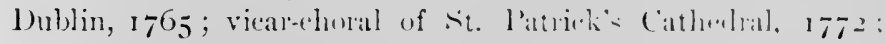

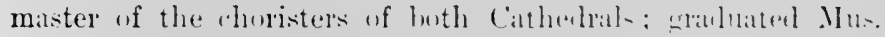
bac., Mublin, 1768: Mus. Inc., 1771; died at Imblin. November 22, 1777 .

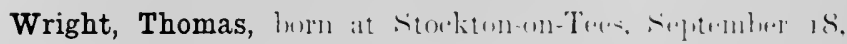

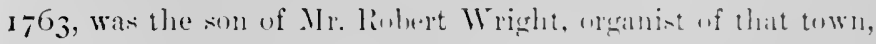
and early "vinced consilerahl. musial ability. When aleven

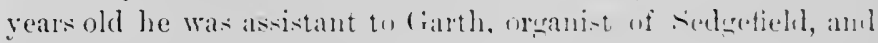
a few years later pupil and asistant with Thumas bilum.

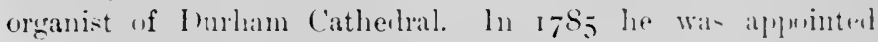

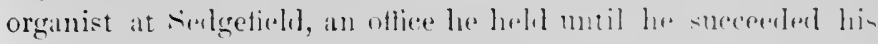
father in 1797 as oreanist at cieneliton. He resignes] the

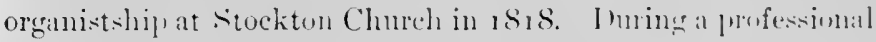

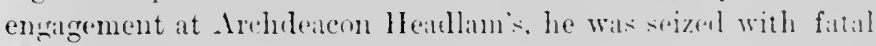

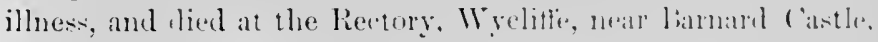

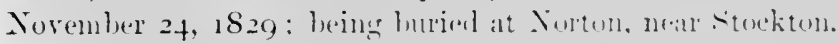




\section{THE CHURCH HYMNARY.}

(1) WITH MUSIC: SOL-FA.

Treble and Alto Parts

Do.,

I Iarmonised Edition

Do.,

on Oxford India paper

frum siet.

(2) WITH MUSIC: STAFF NOTATION.

Family Edition

I) (o., un Oxford India paper

For the Organ

I).,

on Oxford India paper

$$
\begin{array}{ccc}
\text { from } & 2+6 \\
. & 4.6 \\
., & 4.6 \\
., & 12 \div .61
\end{array}
$$

\section{WORDS ONLY.}

Nonpareil Type

hourgeois Type

I)o., on Oxtord Indial paper

Longprimer Type.

Do., on Oxford India paper

I'ica Type .

Do., on Oxford India paper

$$
\begin{aligned}
& \text { from 2il. } \\
& 61 . \\
& \text {.. Is. } 61 \text {. } \\
& \text { 1․ od. } \\
& \text { 2. 6 } 6 \text {. } \\
& \text { 2. Od. } \\
& \text { 5:. or. }
\end{aligned}
$$

\section{THE PSALTER IN METRE (with Tunes.} SOL $=F A$.

Treble and Alto.

lound with the

Do., on Oxford India paper. Alone. Church Hymtary. Harmonised Edition

Do., on Oxfurd India paper

... $\quad$. $j \leqslant 6$ d.

\section{STAFF NOTATION.}

Family Edition

Do., on Oxford Inclia paper

For the Organ

Do., on Oxford India paper

from 1s. 3 d. from 3 \%. Gal.

frum 2s. ol.

,. vi. od.

., 6. oi.

,. $17.6 \mathrm{~d}$.

OXFORD EDITIONS OF THE HOLY BIBLE in a variety of sizes ean be had bound up with the above in One Volume. In most cases Oxford Bibles bound with 'The Church Ilymary' are uniy slightly thicker and eost but litte more than the IBibles alone.

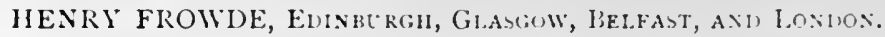




\section{THE HYMNS AND HYMN WRITERS OF THE CHURCH HYMNARY. By the Rev. John Brownlie. Crown 8vo, cloth, pp. viii +364 , price 3 s. $6 \mathrm{~d}$.}

Scotsman.- 'An interesting and instructive supplement to the "Hymnary," and cannot but serve to foster the intelligent use of that noteworthy compilation of sacred verse.'

North British Daily Mail.- 'Mr. Brownlie has well condensed the vast mass of facts and biographical details and has most admirably grouped and arranged it all. It will be a well-read volume for many years to come in very many Scottish households.'

Aberdecn Free Press. - "That Mr. Brownlie has done his part with thorough knowledge and appreciation is manifest throughout its pages. The work will certainly enhance the interest of the "Hymnary," imparting as it does in brief and rememberable form the salient facts concerning the contents of a work that is fast winning its way into the congregations and households of Scotland, and has already been circulated by hundreds of thousands.'

Dundee Conrier.-_'In Mr. Brownlie's volume there will be found the most coinplete information, given in a manner that cannot fail to please the reader. . . . It ought to be much appreciated by the public, for it is the best companion to the "Hymnary" that is ever likely to be published.'

Irish Times. -'A delightful book. . . . It would be impossible to praise too highly the skill and care of the author in editing and in comment. He has been at immense pains to be full and accurate.'

Northern Whig. - 'Mr. Brownlie's biographical notes and comments are most interesting and suggestive, the book forming an important and informing companion to the "Hymnary."

Preslyterian. - This admirable book, which is a fitting fellow to the "Hymnary.",

Free Church of Scotland Monthly._- Mr. Brownlie's book should lie on every minister's study table alongside of the "Hymnary," and the singing in our congregations will be all the more hearty and intelligent as our people become acquainted with it. We have nothing but sincere praise for this book. The table of consensus at the end is specialiy valuable, and will be of service in a variety of ways.'

Guardian.-'Mr. Brownlie's criticisms and judgements on hymns and hymn writers are discerning and independent, and we have found that we generally agree with his verdicts. . . . His criticisms ought to help much towards encouraging a cultured and wholesome taste in hymns. This work, and the "Hymnary" which it illustrates, should be on the shelves of every student of English hymnology.' 


\section{THE HOLY BIBLE. TWO=VERSION EDITION. The}

Authorised Version, with the differences of the Revised Version printed in the Margins, so that both texts can be read from the same page. Printed in clear type, and with central column references. Brevier 8vo, on ordinary paper, from 7s. 61. upwarls; on Oxford India paper, from 10s. 6d. ; interlenved throughout with writingpaper for MIS. notes, from 21s.; or bound with the 'IIelps to the Study of the Bible,' from ISs. 6d. With Sicottish Metrical Psalms, on ordinary paper, gd. extra ; on Oxford India paper, Is. extra.

Glasgere Herald.- 'There can be no doubt that the practical difficulties to which the Bishop of Gloucenter refers have had consideralle influence in preventing the kevined Version from attaining to a larger popularity. . . . No one can quention the value of this two-version edition to teachers, and indeed to all careful bible readers.'

Scotsman.- "Ministers and sunday"school teachers will readily appreciate the advantages of such an edition of the bible. The bishop of Gloucester, who has himelf done so much for the elucidation and explanation of the ticriptures, writes a preface for the volume.

\section{THE OXFORD BIBLE FOR TEACHERS. Containing} the Iloly Scriptures, togrether with a New, Fnlarged, and Hllustrated Edition of the 'Oxford Ilelps to the Study of the lible,' comprising Introductions to the several Books, the Ifistory and Antiquities of the Jews, the results of Modern Discoveries, and the Natural llistory of Palestine, with copious Tables, Concordance, and Indices, and a series of .laps. I'rices, in various sizes and bindings, from $3 \leqslant$ to $£ 5$. Mlost of the editions can be had with the Scottish Yletrical l'salms.

\section{HELPS TO THE STUDY OF THE BIBLE. Taken} from 'The Oxford Bible for Teachers.' New, Enlarged, and Illus. trated Edition. Pearl I6mo, stiff covers, Is. net; nonpariel Swo, cloth boards, 25. 6d.; Large Type lidition, longprimer Sw, cloth boards, $5 \mathrm{~s}$.

BIBLE ILLUSTRATIONS. 'Taken from the above. Cloth boards, 2s. 6 d.

\section{NAVE'S INDEX=DIGEST OF THE HOLY SCRIP=}

TURES. By Okvilite I. NArk, D.l., Chaplain in the Army of the United States. Comprising over 20,000 topics and sub-topics and $100,000$ references. I)my Sro, 1$)$. 1625, and is Coloured Maps, 15 s. ; and in leather bindings.

Expository Times. - "Whatever the subject may be, get this book, turn to the subject, it is sure to be here, and you find all the texts that belong to it. . . Its place is its own. It is perhaps as useful, perhaps as indispensable, as a concordance or a dictionary. It will save time as they do, it will give important instruction. It is superfluou to add that the book is extremely handsome in appearance and workmanship.'

British Weckly (Dr. Makct's Duns).- 'A great advance on the "Concordances" with which we have been hitherto satisfied, furnishing us, as it does, with a well-arranged survey and analysis of all that Scripture says on any given topic.'

HENRY FROWde, Edinbergh, Glasgow, Belfast, aNi) LoNdoN. 


\section{OXFORD EDITIONS OF THE POETS.}

The Complete Poetical Works of Robert Burns. With Notes,

Glossary, Index of First Lines, and Chronological List. Edited by J. Logie Robertsox, M. A. Crown 8vo, 3s. 6d. ; on Oxford India paper, from 8s.; Miniature Edition, Three Vols. in case, from 8s.6d.

The Complete Poetical Works of Sir Walter Scott, with the Author's Introductions and Notes. Edited by J. Logie Robertsox, M.A. Crown 8vo, cloth, 3s. 6d. ; on Oxford India paper, from 8s.; Miniature Edition, Five Vols. in case, from 125.

The Complete Works of William Shakespeare. Edited, with a Glossary, by W. J. Craig, M.A. Crown 8vo, cloth, 3s. 6d. ; on Oxford India paper, from 8s. ; Miniature Edition, Six Vols. in case, from I6s.

The Complete Poetical Works of John Milton. Edited, with a Glossary, by H. C. BeEcilivg, M.A. Crown 8vo, cloth, 35. 6d.; on Oxford India paper, from 8s. ; Miniature Edition, One Volume, from 3s. 6d.

The Poetical Works of William Wordsworth. With Introductions and Notes. Fdited by T. Hutchinson, M.A. Crown 8vo, cloth, 3s. 6d.; on Oxford India paper, from 8s.; Miniature Edition, Five Vols. in case, from 125.

The Early Poems of Alfred Lord Tennyson, including the 'Princess,' 'In Memoriam,' 'Maud,' etc. Crown Svo, cloth, 2s. 6d.; Miniature Edition in One Volume, on Oxford India paper, from 3s. 6d.

The Complete Poetical Works of Henry Wadsworth Long= fellow, including the Copyright Poems. Crown 8vo, $3 \mathrm{~s} .6 \mathrm{~d}$. ; on Oxford India paper, from 8s. ; Miniature Edition, Six Vols. in case, from 12s.

The Poetical Works of John Greenleaf Whittier. Edited by W. Garrett Morder, M.A. With a Portrait. Crown 8vo, 3s. 6d. ; on Oxford India paper, from Ss. ; Miniature Edition, Four Vols. in case, from 14 s. $6 \mathrm{~d}$.

British Anthologies. Edited by Professor E. Arber, F.S.A. To be completed in Ten Volumes. Crown 8vo, cloth extra, 2s. 6d. each; and in leather bindings.

Anthology of French Poetry, Tenth to Nineteenth Centuries. Translated by Henry Carrington, M.A., Dean of Bocking. With a Prefatory Note by the Countess E. Mar'tinengo-Cesaresco. Crown 8vo, cloth extra, 2s. 6 d.

A Treatise on a Practical Method of Training Choristers. By J. Varley Koberts, Mus. Doc. Oxon., Organist and Director of the Choir at Magdalen College, Oxford. Second Edition. Small 4to, cloth back, complete copy (for the Choirmaster), 5s. net; the Exercises only (for the Choristers), 2s. net.

The Treasury of Sacred Song. With Notes, Explanatory and Biographical. By F. T. Palgrave, M.A. Seventeenth Thousand. Extra fcap. 8vo, 45. 6d. ; Oxford India paper, 7s. 6d.

The Treasury of American Sacred Song. Selected and Edited by W. GarretT Horner. New Popular Edition, Revised and Enlarged. Crown 8vo, 3s. 6d.

HENRY Frowde, Edinburgil, Glasgow, Belfast, and London. 



.


. 
